\title{
Ciência e Tecnologia dos Alimentos
}
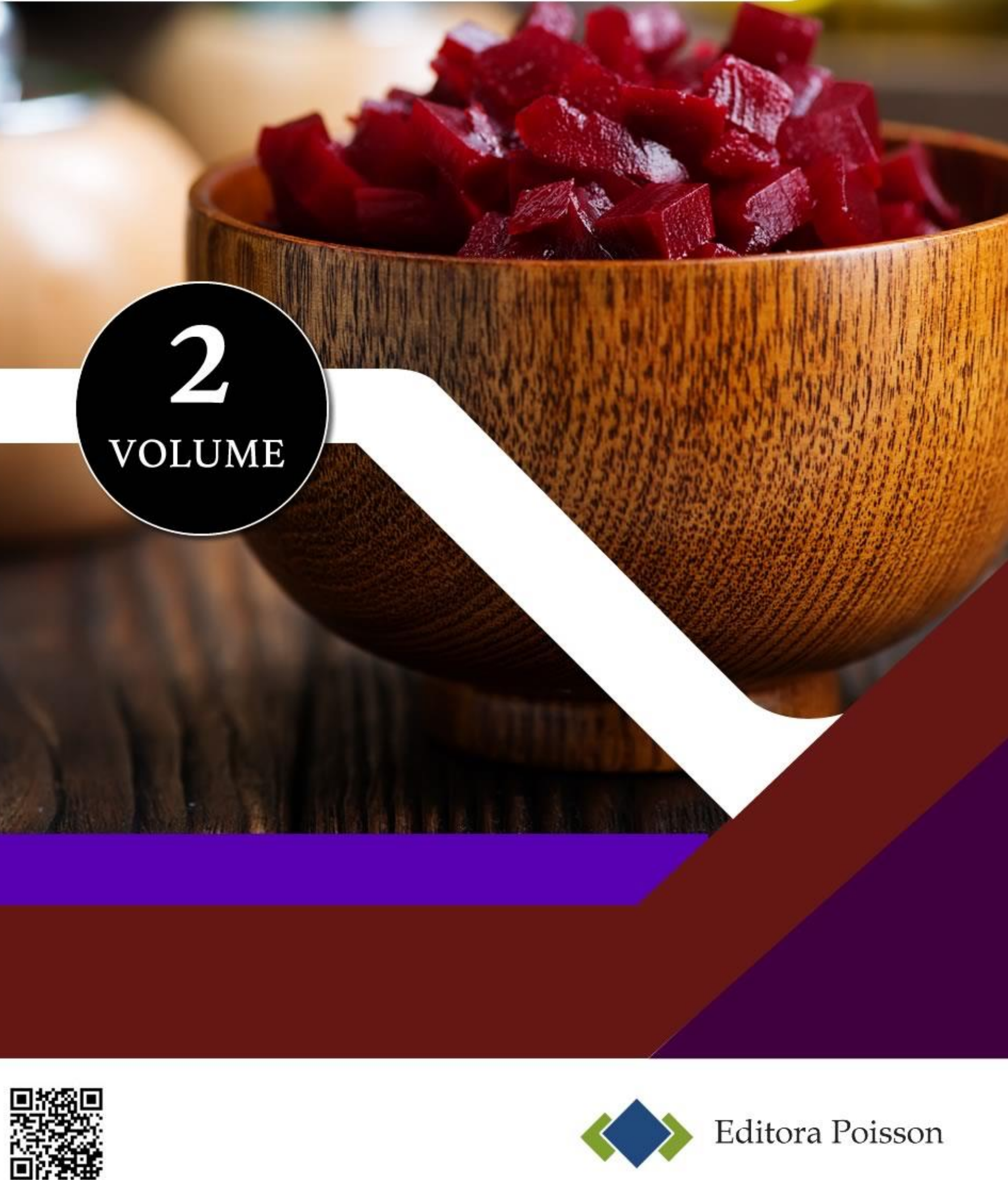
Editora Poisson

\section{Ciência e Tecnologia dos Alimentos Volume 2}

1ạ Edição

Belo Horizonte

Poisson

2019 
Editor Chefe: Dr. Darly Fernando Andrade

\section{Conselho Editorial}

Dr. Antônio Artur de Souza - Universidade Federal de Minas Gerais Msc. Davilson Eduardo Andrade

Dra. Elizângela de Jesus Oliveira - Universidade Federal do Amazonas

Msc. Fabiane dos Santos Toledo

Dr. José Eduardo Ferreira Lopes - Universidade Federal de Uberlândia

Dr. Otaviano Francisco Neves - Pontifícia Universidade Católica de Minas Gerais

Dr. Luiz Cláudio de Lima - Universidade FUMEC

Dr. Nelson Ferreira Filho - Faculdades Kennedy

Msc. Valdiney Alves de Oliveira - Universidade Federal de Uberlândia

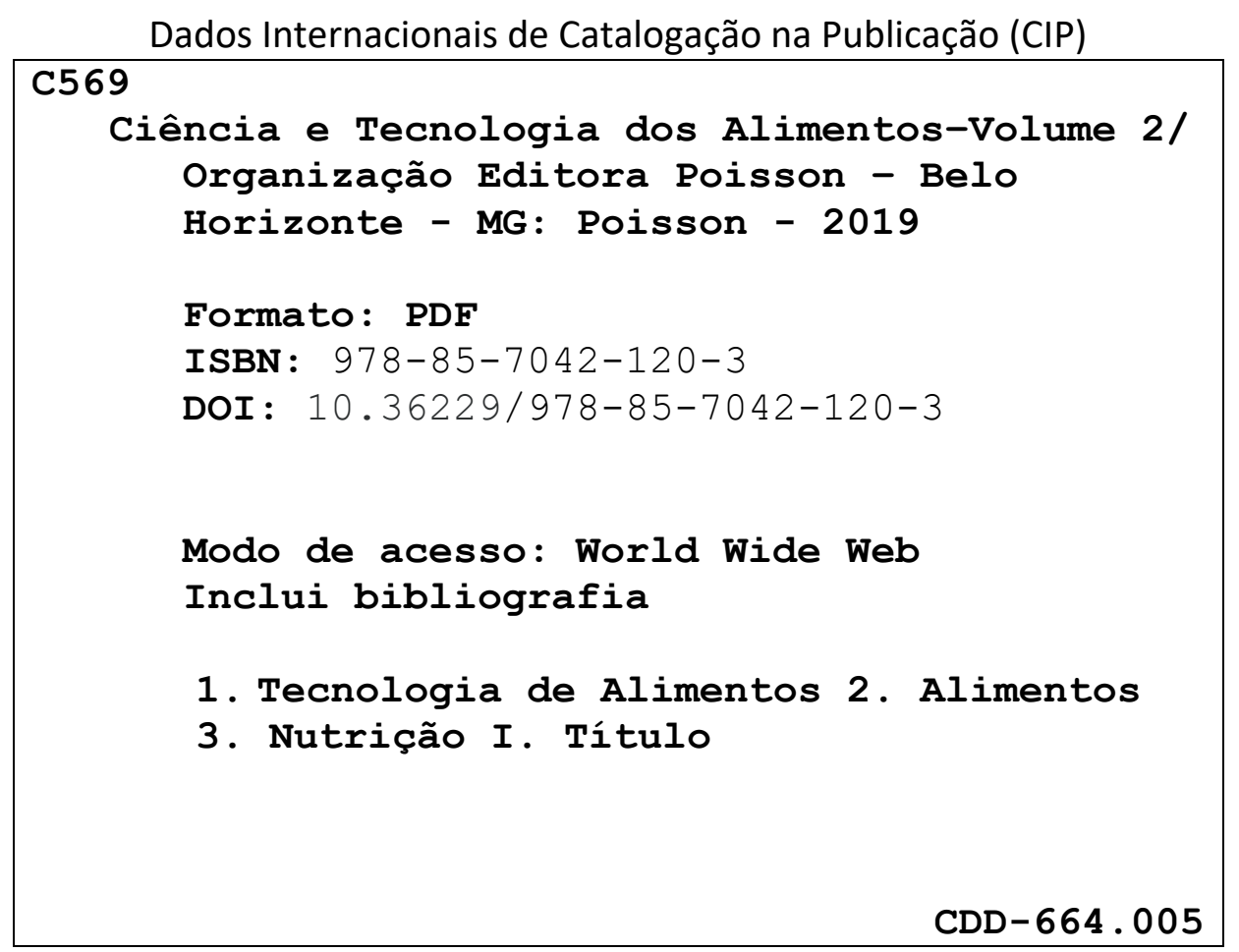

O conteúdo dos artigos e seus dados em sua forma correção e confiabilidade são de responsabilidade exclusiva dos seus respectivos autores.

$\underline{\text { www.poisson.com.br }}$

contato@poisson.com.br 


\section{SUMÁRIO}

Capítulo 1: Análise físico-química do tambaqui (Colossoma macropomum) comercializado em um mercado público 08 Alice Monteiro de Oliveira, Francisco Adalberto do Nascimento Paz, Silvia Maria Gonçalves Vieira Otavio, Luíza Marly Freitas de Carvalho, Joelma Moreira Abreu

DOI: 10.36229/978-85-7042-120-3.CAP.01

Capítulo 2: Caracterização físico-química do jambo-vermelho (Syzygium malaccense ( $L$ ) Merr. \& L.M. Perry) e ensaio preliminar frente à toxicidade. 13

Luciana Gibbert, Francis José Zortéa Merino, Marlene Bampi, Aiane Benevide Sereno, Renata Labronici Bertin, Claudia Carneiro Hecke Kruger

DOI: 10.36229/978-85-7042-120-3.CAP.02

Capítulo 3: Avaliação fisico-química de resíduos agroindustriais de bagaço de maçã eva orgânica. 20

Roseli Quintiliano Lieira, Flavia Maria Vasques Farinazzi-Machado, Rogério Lopes Vieites, Amanda Cristina Alfredo Contrucci Sorbo, Anna Claudia Sahade Brunatti, Alice Yoshiko Tanaka

DOI: 10.36229/978-85-7042-120-3.CAP.03

Capítulo 4: Elaboração e perfil físico-químico e microbiológico de farinha de carcaça de tilápia do nilo (Oreochromis niloticus) 26

Denise Pastore de Lima, Camila Gaio, Thays Scopel, Julianna Matias Vagula

DOI: 10.36229/978-85-7042-120-3.CAP.04

Capítulo 5: Avaliação sensorial e físico-química de mistura para preparo de cappucino a base de fontes proteicas do soro de leite. 30

Giovanna Mazoti Crubelati, Juliana Bueno Ruiz, Suelen Pereira Ruiz Herrig

DOI: 10.36229/978-85-7042-120-3.CAP.05

Capítulo 6: Efeito do branqueamento sobre as características físico-químicas e microbiológicas em acerolas (Malpighia punicifolia DC)

Luis Eduardo Silva Nascimento, Fernanda Vanessa Netto Aragão, Mirla de Nazaré do Nascimento Miranda, Silvana Neves de Melo

DOI: 10.36229/978-85-7042-120-3.CAP.06

Capítulo 7: Extrato hidroalcoólico de própolis: Avaliação de fitoquímicos e da atividade antioxidante e antibacteriana. 42

Cristina Jansen Alves, Tailise Beatriz Roll Zimmer, Fernanda Doring Krumreich, Eliezer Avila Gandra, Rui Carlos Zambiazi

DOI: $10.36229 / 978-85-7042-120-3 . C A P .07$ 


\section{SUMÁRIO}

Capítulo 8: Obtenção de hidrolisado proteico a partir de Tilápia do Nilo (Oreochromis niloticus) e aplicação em produtos alimentícios 48

Cassandra Meireles Terres Ribeiro, André Marcelo Knak, Ricardo Pereira Ribeiro

DOI: 10.36229/978-85-7042-120-3.CAP.08

Capítulo 9: Efeito do tamanho de partícula nas propriedades reológicas de suspensões aquosas de resíduo agroindustrial em diferentes concentrações de sólidos e temperaturas

Tiago Carregari Polachini, Antonio Mulet, Juan A. Cárcel, Javier Telis Romero

DOI: 10.36229/978-85-7042-120-3.CAP.09

Capítulo 10: Avaliação microbiológica de carne bovina moída comercializada em supermercados do município de Cuiabá - MT .

Letícia Gabriela Pozzer Pires, Marina Correa da Costa Abreu, Greika Ferreira Moura, Soyanne Lima Oliveira de Almeida, Cleise de Oliveira Sigarini Sander de Souza, Edivaldo Sampaio de Almeida Filho DOI: 10.36229/978-85-7042-120-3.CAP.10

Capítulo 11: Avaliação da atividade antimicrobiana de óleo essencial de Cravo-da-Índia (Syzigium aromaticum) obtido com $\mathrm{CO} 2 \mathrm{em}$ fase supercrítica 70

Elaine Patrícia Tavares do Espírito Santo, Gardene Dourado Mota, Alex Brito Souza, Silvia Helena Marques da Silva

DOI: 10.36229/978-85-7042-120-3.CAP.11

Capítulo 12: Avaliação de microrganismos indicadores higiênico-sanitários e pesquisa de Salmonella sp. em queijos parmesão ralados comercializados em Campos dos Goytacazes - RJ 76

Silvia Menezes de Faria Pereira, Gabriela Vigneron Aguiar, Clara dos Reis Nunes, João Batista Barbosa, Simone Vilela Talma

DOI: $10.36229 / 978-85-7042-120-3 . C A P .12$

Capítulo 13: Estudo da hidrólise ácida e enzimática da borra de café como alternativa de uso deste resíduo. 82

Diego Sorge de Angeli, Isabel Craveiro Moreira Andrei, Aneli de Melo Barbosa Dekker, Claudio Takeo Ueno, Lucia Felicidade Dias

DOI: 10.36229/978-85-7042-120-3.CAP.13 


\section{SUMÁRIO}

Capítulo 14: Avaliação de atividade antioxidante e do teor de Estireno em fermentados de diferentes clones de cajueiros por cepas comerciais de Saccharomyces cerevisiae

Juliana Cordeiro da Silva, Ivanilton Almeida Nery

DOI: 10.36229/978-85-7042-120-3.CAP.14

Capítulo 15: Conteúdo de bioativos e atividade antioxidante em cultivares de feijãoCaupi antes e após o cozimento 93

Nara Vanessa dos Anjos Barros, Bruna Barbosa de Abreu, Marcos Antônio da Mota Araújo, Maurisrael de Moura Rocha, Regilda Saraiva dos Reis Moreira-Araújo

DOI: 10.36229/978-85-7042-120-3.CAP.15

Capítulo 16: Quantificação da capacidade antioxidante e compostos bioativos presentes no Quipá Tacinga Inamoena (k. Schum) NP Taylor \& Stuppy 97

Ana Cibele Pereira Sousa, Myrella Pereira Pinto, Maurício Eduardo Matos Cavalcante, Stella Regina Arcanjo Medeiros, Alessandro de Lima

DOI: 10.36229/978-85-7042-120-3.CAP.16

Capítulo 17: Aplicação da microscopia eletrônica de varredura na identificação do comportamento morfológico da farinha de algaroba obtida em diferentes tipos de moinhos.

Alan Henrique Texeira, Clovis Queiroz Gouveia, Clóvis Gouveia da Silva, Karina da Silva Falcão

DOI: 10.36229/978-85-7042-120-3.CAP.17

Capítulo 18: Otimização da extração mecânica do Óleo de Nim utilizando metodologia de superfíce de resposta 109

Evely Degraf Terra Parckert, José Roberto Delalibera Finzer

DOI: 10.36229/978-85-7042-120-3.CAP.18

Capítulo 19: Avaliação das condições higiênico-sanitárias em panificadoras da região sul do munícipio de Palmas-TO

Maykon Jhuly Martins de Paiva, Iangla Araújo de Melo Damasceno, Eduardo Sousa dos Anjos

DOI: 10.36229/978-85-7042-120-3.CAP.19 


\section{SUMÁRIO}

Capítulo 20: Qualidade higiênico-sanitária na produção de refeições em hotéis segundo o porte - Gramado-RS.

Patrícia Binz, Heloísa Theodoro, Juliana Rombaldi Bernardi

DOI: 10.36229/978-85-7042-120-3.CAP.20

Capítulo 21: Resíduos de agrotóxicos em mel produzido nas casas de mel da região das Missões- RS

Fernanda Leal Leães, Karla Joseane Perez, Thais de Oliveira Lopes

DOI: 10.36229/978-85-7042-120-3.CAP.21

Autores: 


\section{Capítulo 1}

\section{Análise físico-química do tambaqui (Colossoma macropomum) comercializado em um mercado público}

\section{Alice Monteiro de Oliveira}

Francisco Adalberto do Nascimento Paz.

Silvia Maria Gonçalves Vieira Otavio

Luíza Marly Freitas de Carvalho

Joelma Moreira Abreu

Resumo: 0 estudo propôs-se analisar o Tambaqui (Colossoma macropomum) comercializado no mercado público municipal de Teresina. Foram adquiridas amostras de três bancas e colocadas em sacos plásticos identificados, levadas ao laboratório, onde foram realizadas inicialmente as análises sensoriais, seguidas das análises físico-químicas como a determinação do $\mathrm{pH}$, acidez titulável, prova de Éber. Sensorialmente o pescado se encontrou adequado para o consumo. Os valores de pH das amostras encontram-se adequados à legislação vigente. Quanto à acidez, não existe um padrão para peixes. A prova de Èber foi $100 \%$ negativa para todas as amostras, confirmando, adequação do pescado para consumo humano. De acordo com os resultados das análises supracitadas, o pescado encontra-se próprio para o consumo humano.

Palavras-chave: Pescados; Tambaqui; Análises. 


\section{INTRODUÇÃO}

O comércio mundial de produtos pesqueiros alcançou um recorde mundial de 160 milhões de toneladas no ano de 2013, um consumo mundial de $20 \mathrm{~kg}$ de pescado por pessoa/ano, sendo que a aquicultura contribuiu com quase metade desse valor (FAO, 2014).

Sabe-se que os peixes possuem grande importância nutricional, em função da elevada qualidade de sua proteína, além de ser fonte de lipídios, ácidos graxos ômega-3, vitaminas e sais minerais, superando em valor biológico, outras fontes de origem animal, como a carne bovina e o leite, exceto o ovo (COSTA et al, 2013).

0 pescado é um alimento que se destaca nutricionalmente, sendo indicado para dietas balanceadas e saudáveis (RUXTON, 2011), mas após a sua captura ou despesca o produto sofre uma série de alterações físicas, químicas, bioquímicas e microbiológicas (TAVARES; GONÇALVES, 2011).

As más condições de manipulação, armazenamento e transporte do pescado fresco muito contribuem para a perda da qualidade e mesmo deterioração do pescado desembarcado. Neste caso está incluído o Brasil, onde o quadro é precário em quase todos os locais de descarga do pescado. As práticas tradicionais de passagem do pescado fresco através de um ou mais intermediários, em sua viagem do pescador ao consumidor final, também contribui decisivamente para a perda da qualidade e deterioração do pescado fresco disponível ao consumidor nas feiras livres, mercados, peixarias e supermercados do país (ARAÚJO et al, 2012).

A legislação vigente (Brasil, 1952) preconiza que todo produto de origem animal deve ser previamente submetido à inspeção. A introdução de perigos pode ocorrer em qualquer estágio da cadeia produtiva, por isso há necessidade de se assegurar a proteção em todas as etapas de produção (TEIXEIRA et al., 2009).

Neste sentido, o presente estudo propôs-se analisar o Tambaqui (Colossoma macropomum) comercializado no mercado público municipal de Teresina, destacando seus processos sensoriais e fisico-químicos.

\section{MATERIAL E MÉTODOS}

Trata-se de um estudo transversal, quantitativo e descritivo onde as amostras do Tambaqui (Colossoma macropomum) foram coletadas no mercado público municipal, tendo início às coletas na segunda semana do mês de abril de 2015, compreendendo um período de quinze (15) dias. Seguiu os mesmos procedimentos higiênicos sanitários, manejo, embalagem e transporte que foram utilizados durante o procedimento de venda, para que não houvesse nenhuma alteração nos resultados a serem adquiridos no período das análises. As amostras coletadas foram colocadas em sacos plásticos, identificados com etiquetas que continham informações sobre o número de amostragem, nome do vendedor e data da coleta, além da identificação do local. Em seguida, as amostras dos pescados foram levadas ao laboratório de uma entidade de ensino superior, na cidade de Teresina-PI, onde foram avaliadas as condições em que o pescado se encontrava, observando as características sensoriais fundamentais em um pescado fresco, sendo realizadas em seguida as análises físico-químicas como prova de Èber, acidez titulável e pH que permitiram identificar e caracterizar a qualidade do produto. As análises foram realizadas em triplicata.

\section{RESULTADOS}

Foram realizadas análises das características organolépticas e físico-químicas como a determinação do $\mathrm{pH}$, acidez titulável e prova de Éber das três amostras de tambaqui de bancas diferentes comercializados no mercado público municipal de Teresina, no período de 2015, cujos resultados estão descritos respectivamente nas tabelas 1, 2 e 3. 
Tabela 1 - Características organolépticas do tambaqui comercializado no mercado do público de TeresinaPI.

\begin{tabular}{|l|l|}
\multicolumn{1}{|c|}{ ANÁLISE } & \multicolumn{1}{c|}{ CARACTERÍSTICA } \\
\hline SUPERFÍCIE DO CORPO & Limpa e relativo brilho metálico \\
\hline OLHOS & Transparentes, brilhantes e salientes, ocupando completamente as órbitas \\
\hline GUELRAS & Vermelhas e brilhantes, com odor natural, própria e suave. \\
\hline VENTRE & Roliço, não deixando impressão à palpação dos dedos. \\
\hline ESCAMAS & Brilhantes, bem aderentes à pele. \\
\hline CARNE & Firme e consistência elástica. \\
\hline VÍSCERAS & Integras. \\
\hline ÂNUS & Fechado. \\
\hline
\end{tabular}

Fonte: dados da pesquisa.

As principais mudanças na estrutura e na composição química dos tecidos do pescado podem ser observadas por alterações nas propriedades sensoriais que, junto com os testes químicos, permitem saber se o pescado é apropriado ou não para o consumo (PAREDA, 2005).

Conforme a tabela 1, os resultados encontrados nas análises sensoriais dos pescados em estudo, mostra-se de acordo com a legislação vigente, atestando que, sensorialmente o pescado se encontra adequado para o consumo.

A prática de análise sensorial permite a liberação para o comércio varejista ou a indústria alimentícia somente de pescados em boas condições higiênicossanitárias. No entanto, assim que o pescado é liberado, forma-se uma extensa cadeia de comercialização, que propicia o desenvolvimento de contaminações microbiológicas (GERMANO et al, 1998).

Tabela 2. Determinação dos valores médios de pHmetroe Acidez titulável para as três amostras de tambaqui comercializadas no mercado público de Teresina-PI.

\begin{tabular}{|c|c|c|}
\hline Amostra & pHmetro & Acidez $(\mathrm{v} / \mathrm{m})^{*}$ \\
\hline Banca1 & 6,60 & $0,22 \%$ \\
\hline Banca 2 & 6,70 & $0,30 \%$ \\
\hline Banca 3 & 6,75 & $0,13 \%$ \\
\hline
\end{tabular}

Fonte: dados da pesquisa. *Acidez em solução molar por cento.

A medida de pH é importante por vários motivos, entre eles a verificação da deterioração do alimento com crescimento de micro-organismos (CECCHI, 2003). Esse método em pescado e derivados é um dado indicativo do estado de conservação (IAL, 2008).

Segundo o Regulamento de Inspeção Industrial e Sanitária de Produtos de Origem Animal - RIISPOA (BRASIL, 2001), os limites máximos de $\mathrm{pH}$ para que um peixe possa ser considerado como pescado fresco são de pH inferior a 6,8 na carne externa e a 6,5 na carne interna.

Como mostra os resultados de $\mathrm{pH}$ apresentados na tabela 2, os valores médios obtidos nas análises encontraram-se levemente alterados, porém não sendo classificados como impróprios para o consumo humano. Farias (2006), explica que essas variações de $\mathrm{pH}$ (tabela 2) podem ser justificadas pela ação de alguns fatores, como a exaustão do pescado e ausência de oxigênio no momento da captura e pelo seu manuseio demasiado no período de comercialização. Supostamente pelo consumo completo de glicogênio, fazendo com que o $\mathrm{pH}$ reduza do valor 7,0 para 6,5, em seguida suba rapidamente a valores de 6,6 à 6,7. 
Quanto á acidez, não existe um padrão para peixes, pois a acidez em pescado é uma análise feita para justificar os resultados do $\mathrm{pH}$, uma vez que a mesma pode fornecer dados valiosos na apreciação do estado de conservação do peixe.

Um processo de decomposição, seja por hidrólise, oxidação ou fermentação, altera quase sempre a concentração dos íons de hidrogênio, assim confirmando os possíveis resultados alterados em relação ao pH (ARAÚJO et. al, 2012), como mostra os resultados das análises de acidez, descritos na tabela 2.

Tabela 3 - Resultados das análises físico-químicas para prova de Ebér, realizadas nas três amostras de tambaqui comercializadas no mercado público de Teresina-PI.

\begin{tabular}{|l|c|}
\hline Amostra & Prova de Ebér \\
\hline Banca 1 & Negativo \\
\hline Banca 2 & Negativo \\
\hline Banca 3 & Negativo \\
\hline
\end{tabular}

Fonte: dados da pesquisa.

Segundo Brasil (2008), o estudo da conservação de certos produtos proteicos poderá ser avaliado, também, por meio da reação de Éber para gás sulfídrico, onde se constata a presença de H2S, resultante da decomposição de 17 aminoácidos sulfurados, que, normalmente são liberados nos estágios de decomposição mais avançados. A ação das bactérias na decomposição libera o enxofre dos aminoácidos sulfurados, que será utilizado para a produção do gás sulfídrico.

De acordo com Silva Junior (2007) para a realização desta análise as amostras devem estar em temperatura ambiente $\left(20^{\circ} \mathrm{C}\right)$ e nunca congelada. Os resultados da análise para a prova de Ebér (tabela 3 ) demonstraram que $100 \%$ das amostras tiveram resultados negativos, ou seja, não apresentaram a mancha escura no papel filtro, caracterizando assim um pescado adequado para consumo humano.

Contreras-Guzmán (1994) considera que inúmeros fatores podem influenciar a composição química dos peixes, sendo alguns de natureza intrínseca, tais como fatores genéticos, morfológicos (tamanho e forma) e fisiológicos (migração e desenvolvimento gonadal). Fatores exógenos, tais como clima, estação do ano, abundância e tipo de alimentação também podem afetar a composição corporal.

De acordo com Gonçalves (2011), a complexidade do processo de decomposição do pescado torna impossível o uso de apenas um método para avaliar sua qualidade. Portanto, é mais viável e segura a utilização de métodos combinados.

\section{CONCLUSÃO}

De acordo com os padrões da legislação em vigor para análise sensorial e prova de Èber o peixe Tambaqui (Colossoma macropomum) pode ser classificado como próprio para o consumo humano.

Os resultados das análises de $\mathrm{pH}$ mostram-se levemente alterados em relação ao padrão estabelecido pela legislação nacional, indicando possivelmente estresse prolongado antes da morte.

\section{REFERÊNCIAS}

[1] ARAÚJO, C. E.; MOURA, L. L.; MARTINS, A. L. G. A.; CARVALHO, S. S. A. Avaliação da qualidade microbiológica e físico-química do Tambaqui (Colossomamacropomum )comercializado no mercado municipal em Açailândia-Ma. Palmas- Tocantins. VII Congresso Norte Nordeste de Pesquisa e Inovação. 2012.

[2] BRASIL. Governo do Estado de São Paulo. Secretaria de Estado da Saúde. Coordenadoria de Controle de Doenças. Instituto Adolfo Lutz (IAL). Métodos Físico-Químicos para Análise de Alimentos. 4. ed, 1. ed digital. São Paulo, 2008.

[3] BRASIL. Ministério da Agricultura, Pecuária e Abastecimento. Regulamento da inspeção industrial e sanitária de produtos de origem animal - RIISPOA: pescados e derivados. 2001.

[4] CECCHI, H. M. Fundamentos teóricos e práticos em análise de alimentos. 2a ed. rev. São Paulo. Editora da Unicamp, 2003. 
[5] CONTRERAS-GUZMÁN, E. S. Bioquímica de Pescados e Derivados. Jaboticabal: FUNEP, 1994.

[6] COSTA, V. T.; SILVA, S. R. R.; SOUZA, L. J.; BATALHA, S. O.; HOSHIBA, A. M. Aspectos do Consumo e Comércio De Pescado Em Parintins*. Bol. Inst. Pesca. São Paulo. 2013.v. 39, n. 1, p. 63 - 75.

[7] FARIAS, M. C. A. Avaliação das condições Higiêncio-Sanitárias do Pescado Beneficiado em Industrias Paraenses e Aspectos Relativos à Exposição para Consumo. Núcleo deCiênciasAgrárias e Desenvolvimento Rural. Universidade Federal do Pará. Empresa Brasileirade Pesquisa Agropecuária Amazônia Oriental. Universidade Federal Rural da Amazônia.(Dissertação de Mestrado em Ciência Animal) Belém-PA, 2006.

[8] GERMANO, P. M. L.; OLIVEIRA, J. C. F.; GERMANO, M. I. S. Aspectos da qualidade do pescado de relevância em saúde pública. Hig. Aliment. 1998. v. 12, n. 53, p. 30-7.

[9] GONÇALVES, A. A. Tecnologia do pescado: ciência, tecnologia, inovação e legislação. São Paulo: Atheneu; 2011.

[10] Instituto Adolfo Lutz-IAL. Métodos físico-químicos para análise de alimentos. São Paulo, 2008.

[11] ORGANIZAÇÃO DAS NAÇÕES UNIDAS PARA AGRICULTURA E ALIMENTAÇÃO - FAO. Comércio Global de Peixes Atinge Níveis Recordes. Brasília. 2014.

[12] PAREDA, J. A. O. etal. Tecnologia de Alimentos: Alimento de origem animal. vol. 2. EditoraArtemed. São Paulo. 2005. 279p.

[13] RUXTON, C. H. S. The Benefits of Fish Consumption. Nutrition Bulletin, London, 2011. v. 36, n. 1, p. 6-19.

[14] SILVA JÚNIOR, E. A. Manual de controle Higiênico-Sanitário em Alimentos. $4^{\circ}$ ed. São Paulo: Livraria Varela. 2007. 385p.

[15] TAVARES, M.; GONÇALVES, A. A. Aspectos Físico-químicos do Pescado. In: GONÇALVES, A. A. (Ed.). Tecnologia do Pescado. São Paulo: Atheneu, 2011. p. 10-20. cap. 1.2.

[16] TEIXEIRA, A.C.M.; FENGLER, P., GRANADA, G.G. 2009. Análise das condições higiênico sanitárias na confecção de alimentos em pontos de alimentação de uma festa da cultura Germânica. Revista Higiene Alimentar, São Paulo, v. 23, n. 170/171, p. 186. 


\section{Capítulo 2}

Caracterização físico-química do jambo-vermelho (Syzygium malaccense (L.) Merr. \& L.M. Perry) e ensaio preliminar frente à toxicidade

\section{Luciana Gibbert}

Francis José Zortéa Merino

Marlene Bampi

Aiane Benevide Sereno

Renata Labronici Bertin

Claudia Carneiro Hecke Kruger

Resumo: 0 Brasil é considerado um país de grande diversidade biológica, contudo observa-se um aumento na monotonia alimentar da população. Dentre as espécies disponíveis para alimentação humana na região litorânea do Paraná está o jambo vermelho (Syzygium malaccense (I.) Merr. \& L.M. Perry). Visando explorar o valor nutricional, bem como encorajar sua incorporação na alimentação diária, o presente estudo teve por objetivo determinar a composição físico-química do jambo vermelho e realizar ensaio toxicológico preliminar. As frutas foram colhidas no Instituto Agronômico do Paraná (IAPAR) no município de Morretes, 2016, sendo realizadas as determinações de comprimento, diâmetro, massa, umidade, cinzas, pH, acidez titulável, sólidos solúveis totais, proteínas, lipídios, fibras alimentares e carboidratos. 0 ensaio de toxicidade preliminar foi realizado in vitro utilizando o microcrustáceo Artemia salina calculando a CL50 após 24 horas. Os resultados indicaram que o jambo vermelho liofilizado apresenta alto teor de umidade $(6,76 \%)$, carboidratos $(45,48 \%)$, sendo que destes destacamos o conteúdo de fibra alimentar $(17,85 \%)$ e de açúcares redutores $(12,49 \%)$ podendo contribuir com os indivíduos que buscam alimentos com esse perfil. Além disso, a fruta não apresentou toxicidade preliminar, tornando esses achados inéditos e capazes de contribuir para o incentivo do consumo do jambo vermelho pela população, promovendo assim a biodiversidade alimentar.

Palavras-chave: sociobiodiversidade; caracterização físico-química; Syzygium Malaccense (L.) Merr. \& L.M. Perry; toxicidade preliminar. 


\section{INTRODUÇÃO}

O Brasil é considerado o país com a maior biodiversidade, representando $20 \%$ da flora mundial. Essa riqueza de espécies está relacionada com a cultura e identidade do Brasil, uma vez que é conhecido como o quinto maior país do mundo em extensão territorial e representa uma das dez maiores economias mundial (BRASIL, 2018). No setor da fruticultura, o Brasil é considerado o 3o maior produtor de frutas, sendo que no ano de 2018, foram produzidas e exportadas aproximadamente 30 milhões de toneladas de frutas (IBGE, 2019).

Dentre as famílias que apresentam espécies disponíveis para compor diversidade de frutas brasileiras destaca-se a família Myrtaceae, a qual possui cerca de 145 gêneros e 5.790 espécies de árvores e arbustos já reconhecidas (WCSP, 2018). 0 que se sabe até o momento é que as espécies da família Myrtaceae podem ser utilizadas tanto para consumo, como para obtenção de extratos, óleos e outras formas a serem utilizadas na indústria farmacêutica. Além disso, possuem diversos macro e micronutrientes, e principalmente compostos bioativos, que auxiliam na prevenção e no combate à doenças crônicas não transmissíveis, tais como: problemas cardiovasculares, câncer, problemas respiratórios e diabetes Tipo 2 . Em relação as frutas mais conhecidas dessa família, pode-se citar a goiaba, jabuticaba, pitanga, araçá, araçá-boi e o jambo vermelho (Augusta et al., 2010; Pereira et al., 2012).

O jambo vermelho (Syzygium malaccense (l.) Merr. \& L.M. Perry) é uma fruta que teve sua origem na Índia, podendo ser encontrada no Brasil principalmente nas regiões Nordeste, Sudeste e Sul (Gibbert; Bertin; Kruger, 2017). Na região Sul, especificamente no Paraná, o jambo se adaptou melhor em regiões litorâneas, como nos municípios de Antonina e Morretes, litoral norte do Estado, o qual contém a maior área de floresta nativa devido à presença de unidades de conservação (Biassio, 2011). É uma fruta de aroma floral e de sabor adocicado, a qual pode ser consumida tanto in natura como na forma de geleias, compotas ou outras formulações (Sobral, 2015). A colheita da fruta ocorre entre os meses de janeiro a maio, porém com a elevada produção tem-se observado um grande desperdício, pelo fato do jambo ter uma vida útil in natura reduzido (Araújo, 2009). Os estudos realizados até então destacam que a fruta apresenta alto conteúdo de fibra alimentar, minerais e compostos bioativos, como carotenoides e antocianinas (Falcão; Paralupp; Clemente, 2002; Araújo, 2009; Augusta et al., 2010; Gibbert, 2017; Gibbert; Bertin; Kruger, 2017).

Devido ao fato do jambo vermelho ser alvo de recentes estudos no Brasil, pela diversidade de constituintes químicos (macro, micronutrientes e compostos bioativos), mais estudos necessitam ser realizados com vista a explorar seu valor nutricional, funcional e seus possíveis efeitos benéficos à saúde. Assim, o objetivo deste trabalho foi realizar a caracterização físico-química da fruta obtida na região litorânea do estado do Paraná e realizar ensaio toxicológico preliminar.

\section{MATERIAL E MÉTODOS}

\subsection{AMOSTRAGEM, COLETA E CARACTERIZAÇÃO FÍSICO-QUÍMICA}

Este trabalho foi gerado a partir da apresentação de um resumo expandido no XXV Congresso Brasileiro de Ciência e Tecnologia de alimentos em 2016 e da dissertação de mestrado da primeira autora, defendida no ano de 2017.

A coleta da fruta foi realizada durante o mês de janeiro de 2016, no Instituto Agronômico do Paraná (IAPAR), unidade Morretes, litoral do Paraná, (Latitude 2530'6"S; Longitude 4848'5.22"0). Uma exsicata foi depositada no Museu Botânico Municipal de Curitiba (Paraná, Brasil) e registrada sob número MBM379581.

A partir da amostra coletada, foram selecionadas aleatoriamente 25 frutas para a realização das análises físicas de dimensionamento mínimo e máximo, comprimento e peso. Após esse procedimento, foram descascadas manualmente, separando polpa e casca da semente. As amostras foram congeladas e liofilizadas em equipamento da Liobras® modelo L101.

Foram realizadas as análises de umidade e resíduo mineral fixo (AOAC, 2005), potencial hidrogênico (pH) (AOAC no 942.15, 2000), acidez titulável (AOAC n 942.15, 2000) e sólidos solúveis totais (IAL, 2005). As proteínas foram determinadas pelo método de Kjeldahl, utilizando o fator 5,75 (AOAC no 920.87, 2005), os lipídios totais foram obtidos a partir de extração etérea por fluxo intermitente, utilizando éter etílico como solvente sob refluxo, em aparelho Soxhlet (AOAC no 920.85, 2005) e os carboidratos foram obtidos por diferença (AOAC, 2000). 
0 teor de fibra alimentar total foi determinado pelo método enzimático gravimétrico (AOAC n 985.29, 2000). Os teores de açúcares totais e redutores foram determinados pelo método espectrofotométrico de Somogy (1945) e Nelson (1960) e lidos em espectrofotômetro (UvVis Femto, São Paulo, SP) com comprimento de onda de 482 e a $535 \mathrm{~nm}$.

O valor energético total foi calculado segundo a conversão de Atwater. Os teores de proteínas e de carboidratos foram multiplicados por 4 quilocalorias (kcal), e o teor de lipídios foi multiplicado por 9 kcal (OSBORNE; VOOGT, 1978). O valor energético total correspondeu à soma de todos esses resultados.

\subsection{ENSAIO DE TOXICIDADE}

O ensaio de toxicidade com Artemia salina foi realizado conforme metodologia proposta por Meyer et al., (1982). Para esta análise foram preparados extratos etanólicos de jambo/etanol (50:50) nas concentrações de $10 \mu \mathrm{L} / \mathrm{mL}, 100 \mu \mathrm{L} / \mathrm{mL}$ e $1000 \mu \mathrm{L} / \mathrm{mL}$. Os controles negativos consistiam de tubos com o solvente solubilizador da fração (SDS), o qual foi evaporado juntamente com as amostras. Os valores obtidos foram expressos como CL50.

\subsection{ANÁLISE ESTATISTICA}

Todas as análises foram realizadas em triplicata e os resultados expressos como média e desvio padrão (DP), utilizando o Software Microsoft Excel 2010. Para o ensaio de toxicidade, os dados foram submetidos a análise pelo método estatístico Probits® e determinados os valores da dose letal (DL50) com 95\% de intervalo de confiança.

\section{RESULTADOS E DISCUSSÃO}

\subsection{CARACTERIZAÇÃO FÍSICO-QUÍMICA}

Os dados referentes ao tamanho, dimensões mínima e máxima, densidade e peso individual do jambo vermelho estão expressos na Tabela 1.

Tabela 1 - Caracterização física do jambo vermelho.

\begin{tabular}{|c|c|}
\hline PARÂMETROS & VALORES MÉDIOS* \\
\hline Comprimento $(\mathrm{cm})$ & $6,46 \pm 0,47$ \\
\hline Dimensão mínima $(\mathrm{cm})$ & $1,80 \pm 0,22$ \\
\hline Dimensão máxima $(\mathrm{cm})$ & $5,57 \pm 0,52$ \\
\hline Peso individual do fruto $(\mathrm{g})$ & $94,26 \pm 23,39$ \\
\hline
\end{tabular}

O comprimento médio da fruta é de $6,46 \mathrm{~cm}$, sendo que o jambo possui aparência semelhante a gabiroba (Campomanesia velutina), ambos da mesma família. Moraes et al., (2014) analisaram a dimensão física da gabiroba, sendo que a mesma possui em torno de 5 a $7 \mathrm{~cm}$ de comprimento. Conforme Figura 1, pode-se observar a forma física do jambo vermelho, que também é bastante semelhante ao formato de uma maçã. 
Figura 1 - Fruta de Jambo vermelho.

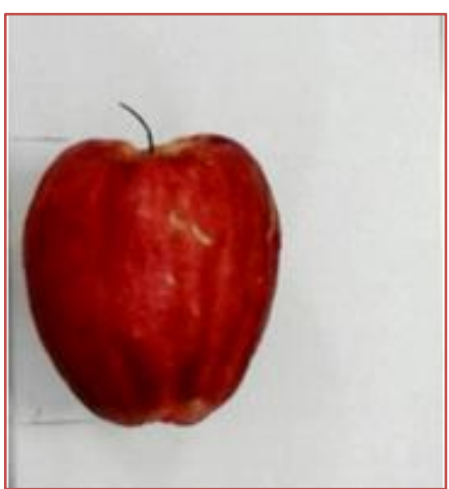

Fonte: Arquivo pessoal de Luciana Gibbert, 2016.

Em relação às dimensões máxima e mínima, a variação foi de $1,80-5,57 \mathrm{~cm}$, indicando o formato levemente elíptico ou oval (Augusta et al., 2010). O valor médio do peso $(94,26 \mathrm{~g}$ ) encontrado no estudo foi superior ao encontrado em outro estudo $(75,86 \pm 16,26$ g) que analisou o jambo vermelho, porém de uma região diferente (São Paulo, Brasil) (Batista et al., 2016). Vale destacar que as características físicas da fruta podem variar de acordo com a sua espécie, região de cultivo e características climáticas, contribuindo com um desenvolvimento maior ou menor da mesma. Dessa forma, o tipo do solo da região litorânea onde o jambo vermelho foi colhido pode ser caracterizado como um solo jovem, o qual possui maior quantidade de matéria orgânica, possibilitando um melhor desenvolvimento das frutas.

Quando analisada a composição centesimal, observou-se um alto teor de umidade da fruta liofilizada (11,8 g/100g), com uma porcentagem expressiva de sólidos solúveis totais (8,37 \% ํㅡrix), baixa acidez titulável (0,58 g de ác. cítrico), baixa quantidade de proteína e lipídio e consequentemente quantidade elevada de carboidrato, devido principalmente ao teor de fibras alimentares e açúcares (Gráfico 1).

Gráfico 1 - Composição nutricional de jambo vermelho liofilizado.

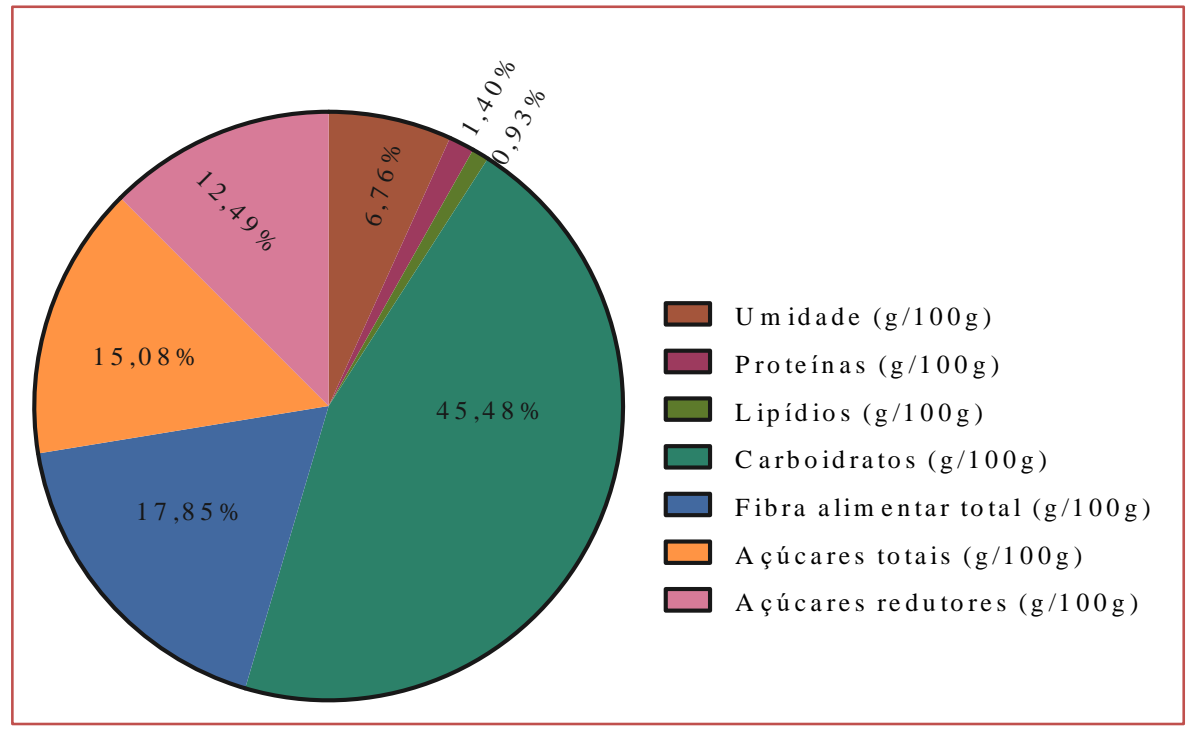

Fonte: Gibbert, 2017.

NOTA: Resultados expressos em porcentagem, referente a fruta liofilizada.

Se os valores de jambo vermelho fossem expressos in natura, a fruta teria em torno de $90 \%$ de umidade, enquadrando-se na classe de frutos suculentos e carnosos (Andrade; Aragão; Ferreira, 1993). Valores semelhantes foram encontrados por outros autores (Morton, 1987; Falcão et al., 2002), relatando que em 100 g de polpa de jambo, a composição média é de $90 \%$ de umidade. Já em relação ao resíduo mineral fixo, Batista et al., (2016) relataram que a quantidade de cinzas da polpa de jambo obtido na região de São 
Paulo foi de $0,31 \mathrm{~g} / 100 \mathrm{~g}$, valor semelhante ao encontrado neste estudo. 0 elevado teor de resíduo mineral fixo encontrado sugere uma quantidade considerável de minerais na fruta.

$\mathrm{O}$ potencial hidrogênico $(\mathrm{pH})$ e acidez titulável verificados no jambo vermelho apresentaram-se semelhantes aos valores encontrados no araçá-boi, com pH de 3,77 e acidez titulável de 0,58 g de ác. cítrico (Gomes et al., 2010). 0 pH que o jambo vermelho possui indica uma característica favorável para fabricação/processamento de doces uma vez que frutas com pH entre 3,1 e 3,6 contribuem para a formação de geis de boa qualidade (Wille et al., 2002).

Além disso, como esperado, a medida que vai ocorrendo o amadurecimento das frutas, os ácidos vão se transformando em açúcares (Nogueira et al., 2002). Isso corrobora com a quantidade de sólidos solúveis totais encontrados no jambo vermelho (8,37\%), pois quanto maior o teor de sólidos solúveis totais, maior será o conteúdo de açúcares presentes no fruto e menor a quantidade de ácidos orgânicos.

Em relação à quantidade de macronutrientes, assim como na composição de outras frutas, as quantidades de proteínas e lipídios do jambo vermelho são baixas. Já a quantidade de carboidratos foi consideravelmente alta, e isso se deve principalmente a quantidade de fibras alimentares e de açúcares que a fruta apresenta. Outro estudo realizado em São Paulo-Brasil já havia relatado que a fruta da mesma espécie era uma fonte rica de fibras alimentares e açúcares (Batista et al., 2016).

A última Pesquisa de Orçamento Familiar (POF) publicada em 2011, a qual é realizada via aplicação de questionário sobre o consumo alimentar da população brasileira, apontou que a ingestão média de fibras alimentares não atinge o recomendado (12,5 g por $1000 \mathrm{kcal})$ sendo que os alimentos fontes de fibras menos consumidas são as frutas e hortaliças (IBGE, 2011). Neste contexto pode-se destacar que o consumo diário de jambo tende a contribuir para que a ingestão diária recomendada de fibra alimentar, seja alcançada, pois o jambo vermelho contém quantidades significativas desse componente.

Ainda, em relação a quantidade de açúcares encontrados na fruta analisada, destacaram-se principalmente os açúcares os redutores $(21,79 \mathrm{~g} / 100 \mathrm{~g})$. A presença desses açúcares, que são geralmente a frutose e/ou glicose, serve como um fator de qualidade na aceitação da fruta tanto na forma in natura como processada (Lago et al., 2006). Dentre as frutas popularmente conhecidas que apresentam baixas quantidades de açúcares destacam-se a banana, que apresenta $20,5 \mathrm{~g} / 100 \mathrm{~g}$ de açúcares, ou a maçã, que possui $15 \mathrm{~g} / 100 \mathrm{~g}$ (Martineau-Fouquet, 2017). Portanto, quando analisadas essas frutas em comparação com o jambo vermelho, ressaltamos que o mesmo se enquadra nessa classificação de baixa quantidade de açúcar, confirmando a fruta como boa opção para consumo pelo público que busca alimentos com baixos teores de açúcares.

\subsection{TOXICIDADE PRELIMINAR}

Em relação aos resultados do ensaio preliminar frente a Artemia salina, verificamos que a fruta não apresentou toxicidade frente ao ensaio preliminar (Tabela 2), pois de acordo com Meyer et al., (1982) para ser tóxico seria necessário que as análises apresentassem valor de concentração letal (CL50) inferior a $1000 \mu \mathrm{g} / \mathrm{mL}$. 0 controle utilizado também não apresentou influência sobre os microcrustáceos.

Tabela 2 - Ensaio de mortalidade de Artemia salina e CL50 utilizando extrato etanólico de jambo vermelho

\begin{tabular}{|c|c|c|c|c|c|}
\hline \multirow{2}{*}{ Fração } & \multicolumn{3}{|c|}{ Mortalidade/Concentração ( $\mu \mathrm{g} / \mathrm{mL})$} & \multirow{2}{*}{$\begin{array}{c}\text { CL50 } \\
(\mu \mathrm{g} / \mathrm{mL})\end{array}$} & \multirow{2}{*}{$\begin{array}{c}\text { Intervalo de } \\
\text { confiança de } \\
95 \%(\mu \mathrm{g} / \mathrm{mL})\end{array}$} \\
\hline & 10 & 100 & 1000 & & \\
\hline Jambo vermelho & 8 & 7 & 7 & $>1000$ & - \\
\hline Dodecil sulfato de sódio (SDS) & 0 & 0 & 0 & $>1000$ & - \\
\hline
\end{tabular}

Diversos fatores podem interferir no êxito do ensaio frente a Artemia salina, tais como: luz, temperatura, tempo de eclosão dos ovos, água utilizadas no teste e contaminação das substâncias analisadas. Por isso, se trata de um teste que exige extremo cuidado durante a realização de todas as etapas, para que assim os resultados sejam confiáveis (Ferraz Filha et al., 2012). 


\section{CONCLUSÃO}

O jambo vermelho coletado no litoral do estado do Paraná apresenta composição semelhante a frutas da mesma espécie em outras regiões e da mesma família, destacando-se em relação aos teores de carboidratos, especialmente de fibras alimentares. Além disso, conforme o ensaio preliminar frente a Artemia salina, a fruta não apresentou toxicidade preliminar. Esse achado é inédito e contribui para o incentivo do consumo dessa fruta pela população, promovendo assim a biodiversidade alimentar.

\section{REFERÊNCIAS}

[1] ANDRADE, Jerusa; ARAGÃO, Carlos G.; FERREIRA, Sidney A. N.(1993). Caracterização física e química dos frutos de Araçá-Pêra (Psidium acutangulum). Acta Amazônica, 23 (2), 213- 217.

[2] AOAC (ASSOCIATION OF OFFICIAL ANALYTICAL CHEMISTRY). (2000). Official Methods of Analysis (17 ed.). Washington, D. C.

[3] AOAC (ASSOCIATION OF OFFICIAL ANALYTICAL CHEMISTIS). (2005). Official methods ofanalysis of the AOAC (18 ed.). Gaithersburg, M.D, USA.

[4] ARAÚJO, Luciares Costa. Otimização da desidratação osmótica do jambo - vermelho (Syzygium malaccense) (2009). 165 f. Tese (Doutorado) - Curso de Pós-graduação em Ciência e Tecnologia de Alimentos, Universidade Federal Rural de Pernambuco, Recife.

[5] AUGUSTA, Ivanilda Maria; RESENDE, Josane Maria; BORGES, Soraia Vilela; MAIA, Maria Cristina (2010). Caracterização física e química da casca e polpa de jambo vermelho (Syzygium malaccensis, (L.) Merryl \& Perry). Ciência e Tecnologia de Alimentos, Campinas, 30(4), 928-932.

[6] BATISTA, Angela Giovana; SILVA; Juliana Kelly; CAZARIN, Cinthia Betim; BIASOTO, Aline Camarão Telles; SAWAYA, Alexandra Christine Helena Frankland; PRADO, Marcelo Alexandre; JUNIOR, Mario Roberto Marostica. Redjambo (Syzygium malaccense): Bioactive compounds in fruits and leaves (2016). Food Science And Technology, São Paulo, 1(1), 1-8.

[7] BIASSIO, A.(2011). Agrobiodiversidade em escala familiar nos municípios de Antonina e Morretes (PR): Base para sustentabilidade socioeconômica e ambiental. (Dissertação de Mestrado) - Curso de Curso de Pós-Graduação em Engenharia Florestal, Setor de Ciências Agrárias, Universidade Federal do Paraná, Curitiba.

[8] BRASIL. Ministério da Saúde. Plano de ações estratégicas para o enfrentamento das Doenças Crônicas não Transmissíveis (DCNT) no Brasil 2011-2022. Brasilia- 1ạ edição. Disponível : http://bvsms.saude.gov.br/bvs/publicacoes/plano_acoes_enfrent_dcnt_2011.pdf. Acesso em: 30 ago. 2018.

[9] FALCÃO, Martha de Aguiar; PARALUPP, Norival; CLEMENT, Charles. Fenologia e produtividade do jambo (Syzygium malaccensis) na Amazônia Central (2002). Acta Amazonica, Manaus, 1(32),3-8.

[10] FERRAZ FILHA, Z. et al. Brine shrimp (Artemia salina Leach) bioassay of extracts from Lychnophoriopsis candelabrum and different Lychnophora species. Revista Brasileira de Plantas Medicinais, Botucatu, v. 14, n. 2, p.358361 , mar. 2012.

[11] GIBBERT, L. Caracterização físico-química, potencial antioxidante e avaliação de toxicidade preliminar do jambo vermelho (Syzygium malaccense (L.) Merr. \& L.M.Perry). 2017. 83 f. Dissertação (Mestrado) - Curso de Pós Graduação em Alimentação e Nutrição, Universidade Federal do Paraná, Curitiba, 2017.

[12] GIBBERT, L.; KRUGER, C. ; BERTIN, R. . Breve revisão da espécie Syzygium malaccense (L.) Merr. \& L.M. Perry como fonte de compostos bioativos. Visão acadêmica (Online), v. 18, p. 140-153, 2017.

[13] GOMES, Ronald Belo; VIANA, Eliseth de Souza; JESUS, Jaciene Lopes; SILVEIRA, Soraia Machado, FONSECA, Mércia Damasceno, SACRAMENTO, Célio Kersul. Avaliação físico-química de geleia de araçá-boi com banana (2010). Embrapa Mandioca e Fruticultura, Bahia.

[14] IAL. Normas Analíticas do Instituto Adolfo Lutz. São Paulo: Instituto Adolfo Lutz, 2005.

[15] IBGE: Instituto Brasileiro de Geografia e Estatística (2011). Ministério da Saúde (Org.). Pesquisa de orçamentos familiares 2008-2009: Análise do consumo alimentar pessoal no Brasil. Rio de Janeiro. Disponível em: <https://biblioteca.ibge.gov.br/visualizacao/livros/liv50063.pdf>. Acesso em: 11 jun. 2019.

[16] IBGE: Instituto Brasileiro de Geografia e Estatística. (2019). Levantamento sistemático da produção agrícola. Disponível em: https://biblioteca.ibge.gov.br/visualizacao/periodicos/2415/epag_2019_jan.pdf.

[17] LAGO, E. S.; GOMES, E.; SILVA, R. Produção de geleia de jambolão (Syzygium cumini Lamarck): processamento, parâmetros físico - químicos e avaliação sensorial. Ciência e Tecnologia de Alimentos, v.26, n.4, p. 847-852, 2006. 
[18] MARTINEAU-FOUQUET, C. La Balance à index glycémique: Elle vousdit tout sur quelque 200 aliments : Index Glycémique, glucides, lipides et calories. Disponível em: . Acesso em 13 abr. 2017.

[19] MEYER, B; FERRIGNI, N; PUTMAN, J.; JACOBSEN, L.; NICHOLS, David; MCLAUGHLIN, Nicols. Brine shrimp: a convenient general bioassay for active plant constituents (1982). Planta Med., 45(5), 31-4.

[20] MORAIS, L. M. F.; CONCEIÇÃO, G. M. da; NASCIMENTO, J. de M. Família Myrtaceae: Análise morfológica e distribuição geográfica de uma coleção botânica. Agrarian Academy, Goiania, v. 1, n. 1, p.1-317, abr. 2014.

[21] NELSON, N.A photometric adaptation of Somogyi method for determination of glucose.Journal of Biologic Chemistry, Bethesda, v. 153, n. 2, p.375-380, Feb. 1960.

[22] MORTON, Julia. Fruits of Warm Climates (1987). Maplay Apple. Disponível em: <http://www.pssurvival.com/ps/plants/Crops_Fruits_Of_Warm_Climates_2004.pdf>.

[23] NOGUEIRA, R. et al. Efeito do estádio de maturação dos frutos nas características físicoquímicas de acerola. Pesquisa Agropecuária, Brasília: v. 37, n.4, 2002.

[24] OSBORNE, D.R.; VOOGT, P.The analysis of nutrient infoods. Academic Press, London, p. 156-158, 1978

[25] PEREIRA, Marina Pereira; STEFFENS, Rosana; JABLONSKI, André; HERTZ, Plinho; RIOS, Alessandro; VIZZOTTO, Márcia; FLORES, Simone. Characterization and antioxidant potential of Brazilian fruits from the Myrtaceae Family (2012). Journal Of Agricultural And Food Chemistry, Brasil, 60(1), 3061-3067.

[26] SOBRAL, M. et al. Myrtaceae in Lista de Espécies da Flora do Brasil. Jardim Botânico do Rio de Janeiro. Disponível em: <http://floradobrasil.jbrj.gov.br/jabot/floradobrasil/FB37162>. Acesso em: 17 Nov. 2015.

[27] SOMOGY, M. Determination of blood sugar. Journal of Biological Chemistry, Bethesda, n. 160, p. 69 - 73, 1945.

[28] WCSP. 2018. World checklist of Myrtaceae. Disponível em https://www.press.uchicago.edu/ucp/books/book/distributed/W/bo9857143.html. Acesso em 06 fevereiro 2018.

[29] WILLE, G. M. F.et al. Desenvolvimento de tecnologia para a fabricação de doce em massa com araçá-pêra (Pssidium acutangulum D. C.) para pequeno produtor. Ciência e Agrotecnologia, v. 28, n. 6, p. 1360-1366, 2002. 


\section{Capítulo 3}

\section{Avaliação fisico-química de resíduos agroindustriais de bagaço de maçã eva orgânica}

\section{Roseli Quintiliano Lieira}

Flavia Maria Vasques Farinazzi-Machado

\section{Rogério Lopes Vieites}

Amanda Cristina Alfredo Contrucci Sorbo

Anna Claudia Sahade Brunatti

Alice Yoshiko Tanaka

Resumo: 0 grande desafio agroindustrial é o reaproveitamento da biomassa gerada no processamento. Aproveitar o alimento integralmente pode ser uma alternativa que diminui o impacto ambiental e contribui com as necessidades nutricionais da dieta. 0 objetivo desse estudo foi determinar a composição centesimal e também dos minerais presentes no bagaço de maçã orgânica cultivar Eva. A maior fração da composição do bagaço foi a umidade, seguida dos carboidratos, com destaque para o teor de fibras que representou 4,27g 100g-1. Os teores de proteínas e cinzas foram 0,36g 100g-1 e 0,21g $100 \mathrm{~g}-1$, respectivamente, enquanto que a fração de lipídeos foi inferior aos demais componentes. Quanto ao perfil de minerais no bagaço, os teores de cálcio encontrados (1 g kg-1) foram superiores aos valores da polpa da fruta. Para o sódio e o cobre os valores médios encontrados foram $70 \mathrm{mg} \mathrm{kg}-1$ e $20 \mathrm{mg} \mathrm{kg}$-1, respectivamente. Esses resultados mostram a importância nutricional dessa biomassa na alimentação humana.

Palavras-chave: resíduos orgânicos; reaproveitamento; alimento. 


\section{INTRODUÇÃO}

O Brasil está entre os maiores produtores agrícolas mundiais, ocupando o terceiro lugar no "ranking" de produção de frutas (SEAB, 2015). 0 grande destaque do agronegócio no país se dá ao setor de fruticultura, que vive um de seus momentos mais dinâmicos, por conta dos mais diversos tipos de clima existentes o que possibilita a produção de uma ampla variedade de espécies produzidas em todas as regiões do País. 0 grande impulso nas cadeias produtivas e exportadoras se dá ao uso de eficientes sistemas de cultivo e rastreamento, associados à sustentabilidade e ampliando a oferta de frutas para a população brasileira (Anuário Brasileiro de Fruticultura, 2015). De acordo com Nascimento Filho e Franco (2015), há uma estimativa de 30 a $40 \%$ de resíduos agroindustriais gerados no processamento de frutas produzidas no país.

Segundo Schneider et al. (2012), as agroindústrias no Brasil geraram mais de 290 milhões de toneladas de resíduos provenientes das principais culturas brasileiras, mesmo com o acumulado do ano de 2012 tendo uma queda de 1,6\% (IBGE, 2013). Devido sua composição rica em matéria orgânica o descarte inadequado, pode se tornar um grande potencial de contaminação de solos e corpos hídricos, através de lixiviações, causando um fator impactante de desequilíbrio ambiental. Diversas agroindústrias processadoras de frutas no Brasil estão se empenhando cada vez mais em buscar alternativas eficazes para o descarte dos subprodutos sólidos gerados pela industrialização de sucos e derivados (Silva et al., 2019; Lima et al., 2018; Manrich et al., 2017; Ferreira et al., 2015).

No Brasil a agricultura orgânica vem crescendo rapidamente desde a década de 1990, de acordo com o levantamento do instituto internacional de pesquisas Euromonitor, em 2014 cerca de US\$ 35 bilhões foram movimentados pelos produtos naturais no Brasil, atingindo um percentual de $98 \%$ entre os naturais, orgânicos e funcionais, enquanto que os alimentos e bebidas tradicionais chegaram aos $68 \%$ e uma estimativa maior ainda de 14,8\% para os produtos funcionais até o ano de 2018 (Consumo..., 2015).

A produção de produtos orgânicos movimentou no ano de 2014 um total de 80 milhões de dólares em todo o mundo, sendo que o mercado americano apresentou o maior crescimento nesse período (FIBL, IFOAM, 2017). Em 2017, a agricultura orgânica atingiu 181 países, num total mundial de 69,8 milhões de hectares, sendo as regiões de maior abrangência encontradas na Oceania, Europa e América Latina (FIBL, IFOAM, 2019).

O município de Botucatu, localizado a $235 \mathrm{Km}$ de São Paulo, destaca-se por ter sido o pioneiro em agricultura orgânica no país, no início da década de 70. Atualmente a Estância Demétria é tida como referência comercial, um grupo pioneiro que se instalou com uma experiência bem sucedida (Sganzerla et al., 2013). Devido a não utilização de agrotóxicos nesse cultivar, os frutos tornam-se mais vulneráveis ao ataque de pragas, insetos e doenças, comprometendo cerca de $30 \%$ da produção, quando comparada ao cultivo convencional, e estas perdas podem chegar aos $15 \%$.

Visando diminuir o alto índice de perda desses frutos, produtores orgânicos do município em parceria com a equipe do Laboratório de Tecnologia de Alimentos da Faculdade de Ciências Agronômicas, Unesp, Campus de Botucatu, buscam novas tecnologias com melhor aproveitamento, minimizando descartes das mesmas. Assim o objetivo deste estudo foi analisar as características físico-químicas dos resíduos de maçãs Eva orgânicas.

\section{MATERIAL E MÉTODOS}

Matéria-Prima - As amostras de bagaço de maçã cultivar Eva orgânica safra 2015/2016, foram obtidas após o processo de extração do suco, utilizando moinho de martelo marca MECAMAU - modelo M037 e prensa hidráulica marca AGM, no Laboratório de Tecnologia de Bebidas, da Faculdade de Ciências Agronômicas, Unesp, Campus de Botucatu-SP. Em seguida os resíduos foram acondicionados em sacos plásticos de $5 \mathrm{~kg}$ e armazenados em freezer a $-18^{\circ} \mathrm{C}$ até o momento das análises.

Métodos analíticos - As amostras foram analisadas no Laboratório de Análises do Centro de Raízes e Amidos Tropicais da Unesp, Campus de Botucatu - CERAT. Os bagaços foram caracterizados quanto à composição centesimal, sendo as análises realizadas em triplicata.

Determinação do teor de umidade - Para a determinação do teor de umidade as amostras foram colocadas em estufa a $105 \stackrel{\circ}{\circ}$ por 8 horas até a obtenção de massa constante. Após esse período foram retiradas da estufa e colocadas em dessecador e posteriormente pesadas, obedecendo ao método AOAC (2012). Os resultados foram expressos g $100 \mathrm{~g}-1$. 
Determinação do teor de cinzas - Para a determinação do teor de cinzas as amostras foram submetidas à combustão em mufla a $550^{\circ} \mathrm{C}$, colocadas em dessecador e pesadas posteriormente (AOAC, 2012). Os resultados foram expressos na base úmida em g $100 \mathrm{~g}-1$.

Determinação do teor de proteína - As proteínas foram quantificadas pelo método de Kjeldahl, conforme AOAC (2012). 0 fator utilizado para conversão do teor de nitrogênio em proteína bruta foi de 6,25. Os resultados foram expressos na base úmida em g $100 \mathrm{~g}-1$.

Lipídeos - Para determinação de lipídeos foram utilizados aproximadamente $3 \mathrm{~g}$ de cada amostra e realizadas em extrator Soxhlet, utilizando éter de petróleo para a extração, conforme metodologia descrita por AOAC (2012). Os resultados foram expressos na base úmida em g $100 \mathrm{~g}-1$.

Determinação de carboidratos - Os carboidratos foram quantificados a partir de $500 \mathrm{mg}$ de cada amostra em erlenmeyer, acrescentando-se $60 \mathrm{~mL}$ de álcool $50 \%$, sendo em seguida, colocada em banho com aquecimento a 60 a $65^{\circ} \mathrm{C}$ por 60 minutos. Depois, acrescentou-se $1 \mathrm{~mL}$ de $\mathrm{HCl}$ p.a. e as amostras retornaram ao banho por mais 60 minutos, sendo após resfriadas, neutralizadas e diluídas. 0 teor de açúcares totais foi determinado pelo método de Somogyi, adaptado por Nelson (1944). Os resultados foram expressos na base úmida em g $100 \mathrm{~g}-1$.

Determinação do teor de fibra - 0 teor de fibras totais foi determinado por hidrólise ácida seguida de hidrólise alcalina. Foram utilizados $3 \mathrm{~g}$ de cada amostra processadas em bloco digestor de fibras, obedecendo à metodologia proposta por AOAC (2012). Os resultados foram expressos na base úmida em $g$ $100 \mathrm{~g}-1$.

Teor de minerais - Os minerais foram determinados conforme metodologia descrita por Malavolta et al. (1974). Para análise de fósforo, a leitura da absorbância foi medida 38 em espectrofotômetro UV-VIS (FEMTO) a $420 \mathrm{~nm}$. Os resultados de fósforo foram expressos em percentagem. Os demais minerais, potássio, cálcio, sódio, cobre e magnésio foram analisados utilizando espectrofotômetro de absorção atômica modelo 2380 (PERKIN ELMER). Para realização das análises foi utilizado $1 \mathrm{~mL}$ do extrato, diluído em $9 \mathrm{~mL}$ de óxido de lantânio a 0,5\%, a leitura foi feita diretamente na solução e os resultados expressos em mg kg-1.

\section{RESULTADOS E DISCUSSÃO}

Os resultados das análises de umidade do bagaço de maçã orgânica Eva (Tabela 1) foram semelhantes aos valores encontrados por Wosiacki e Nogueira (2010) em maçãs de mesa cultivadas em sistema convencional (75 a 87 g 100g-1). Segundo estes autores, a variação de umidade dos bagaços pode ser decorrente do processo tecnológico aplicado na extração do suco.

Druzian e Pagliarini (2007) encontraram valores médios de 80,29 g 100g-1 de umidade no resíduo resultante do processamento do suco de maçã Fuji, e em estudo conduzido por Ferrandini (2014) o bagaço de maçãs cultivar Gala, proveniente do processo de produção de doce de maçã, apresentou 73,07 g $100 \mathrm{~g}-1$ de umidade.

Tabela 1 - Caracterização Centesimal do bagaço da Maçã orgânica cultivar Eva

\begin{tabular}{|c|c|}
\hline Parâmetros Analis & Resultados em g 100g-1 \\
\hline Umidade & $86,7 \pm 0,436^{*}$ \\
\hline Cinzas & $0,21 \pm 0,010$ \\
\hline Proteínas & $0,36 \pm 0,010$ \\
\hline Lipídeos & $0,084 \pm 0,003$ \\
\hline Carboidratos & $7,84 \pm 0,026$ \\
\hline Fibras & $4,27 \pm 0,025$ \\
\hline
\end{tabular}

*Médias e desvio padrão 
Os valores observados para cinzas no bagaço de maçã foram superiores aos encontrados por Wosiacki e Nogueira (2010) no cultivo convencional de maçãs de mesa ou destinada à industria, onde encontraram 1,80 g $100 \mathrm{~g}-1$.

Os teores de proteínas neste estudo foram inferiores aos observados por Albuquerque (2003), no qual, a proteína do bagaço de maçãs 0,556 g 100g-1 foi utilizada para a produção de proteína microbiana. Apresentaram-se inferiores também quando comparados ao estudo de Druzian e Pagliarini (2007), cujo bagaço proveniente da maçã Fugi apresentou 1,79 g 100g-1 de proteínas.

De acordo com Paganini et al. (2004) os açucares em maior quantidade presentes na maçã correspondem aos redutores, glicose e frutose, com menor teor de sacarose, cuja maior parte é extraída juntamente com o suco, no processo de extração. 0 resultado da análise de carboidratos revelou valores médios de 7,84 g 100g-1. Segundo Wosiacki e Nogueira (2010), o bagaço pode conter até 14\% de sólidos solúveis, com mistura de glicose, frutose e sacarose, o que o torna muito susceptível à deterioração por microorganismos.

Considerando os teores de fibras, os valores encontrados 4,27 g 100g-1 enquadram o bagaço de maçã orgânica Eva em categoria "moderada" de alimentos fontes de fibras, pois, segundo o critério de classificação adaptado do Expert Advisory Commiteeon Dietary Fiber do Canada (1985), citado por Mattos e Martins (2000), se enquadram nesta categoria os alimentos com teores de fibra entre 2,4 e 4,4 g $100 \mathrm{~g}-1$.

Valores superiores de fibras totais foram encontrados no trabalho de Druzian e Pagliarini (2007), no bagaço de maçãs Fugi (15,34 g 100g-1). Em bagaços desidratados de maçãs Gala foram encontrados valores entre 40,91 e 43,02 (g/100g) de fibras totais (Fertonani et al., 2006; Coelho e Wosiacki, 2010).

Em estudo de Elvas (2016), o bagaço constituído de variedades de maçãs Golden (60\%), Starking (38\%) e Reineta (2\%) cultivadas em sistema convencional apresentou 65,78 g 100g-1 e 4,95 g $100 \mathrm{~g}-1 \mathrm{de}$ fibra dietética insolúvel e solúvel, respectivamente.

Tabela 2 -Teores de Minerais encontrados no bagaço de Maçã orgânica cultivar Eva

\begin{tabular}{|c|c|c|c|}
\hline Minerais Analisados & Cálcio & Cobre & Sódio \\
\hline Valores e Concentrações & $1 \mathrm{~g} / \mathrm{kg}-1$ & $20 \mathrm{mg} / \mathrm{kg}-1$ & 70 mg/kg-1 \\
\hline
\end{tabular}

Fonte: Centro de Raízes e Amidos Tropicais - CERAT

Os valores de cálcio presentes no bagaço de maçã Eva orgânica representados na Tabela 2 mostram teores médios de 1 g kg-1. Wosiacki e Nogueira (2010) encontraram valores de 4,68 mg 100 g1 em maçãs convencionais. A importância do consumo de cálcio nos alimentos ocorre em virtude de sua deficiência na população provocar osteoporose em adultos e raquitismo em crianças, pois atua em conjunto em atividades hormonais vitais ao metabolismo (Shils et al., 2003).

Considerando os valores de cobre (20 mg kg-1), estes foram superiores aos encontrados por Wosiacki e Nogueira (2010) em cultivar Red dellicius (0,04 mg 100g-1), diferença que pode ser em decorrência da dureza da água (OMS, 2008).

Os teores de sódio foram superiores aos valores encontrados por Wosiacki e Nogueira, (2010), em maçãs cultivar Red dellicius (4,18 mg 100g-1). Segundo Cardoso (2006), o sódio é um mineral que atua no controle da absorção e transporte de alguns nutrientes, como água, glicose, cloro e aminoácidos e imprescindível na função metabólica da bomba $\mathrm{Na} / \mathrm{K}$.

Não foram encontrados valores expressivos para os minerais potássio, fósforo e magnésio nas amostras de bagaços de maçã Eva orgânica neste estudo.

\section{CONCLUSÕES}

Os resíduos da maçã orgânica cultivar Eva apresentaram concentrações de nutrientes semelhantes às maçãs convencionais, com teores expressivos de fibras totais. No entanto, fatores como condições edafoclimáticas podem influenciar diretamente nestes resultados. Ainda assim, considera-se válido investir em tecnologias para o melhor reaproveitamento dessa biomassa como desenvolver um alimento com apelo funcional e deixar de ser destinada apenas a ração animal. 


\section{REFERÊNCIAS}

[1] Albuquerque, P. M. (2003). Estudo da produção de proteína microbiana a partir do bagaço de maçã. (Dissertação de Mestrado). Universidade Federal do Rio Grande do Sul, Porto Alegre.

[2] Anuário Brasileiro de Fruticultura (2015). Santa Cruz do Sul: Gazeta Santa Cruz.

[3] AOAC - Association of Official Analytical Chemists. (2012). Official methods of analysis of AOAC international(19th edition). Gaithersburg.

[4] Cardoso, M. A. (2006). Nutrição humana: nutrição e metabolismo. Rio de Janeiro: Guanabara Koogan.

[5] Coelho, L. M. \& Wosiacki, G. (2010). Avaliação sensorial de produtos panificados com adição de farinha de bagaço de maçã. Revista Ciências e Tecnologia de Alimentos, 30(3), 582-588.

[6] Consumo de produtos funcionais crescem no Brasil (2015). Jornal do Brasil - Ciência e Tecnologia. 06 set. 2015.Disponível em http://www.jb.com.br/ciencia-e-tecnologia/noticias/2015/09/06/consumo-de-produtosfuncionais-crescem-no-brasil/

[7] Druzian, J. I. \& Pagliarini, A. P. (2007). Produção de goma xantana por fermentação do resíduo de suco de maçã Xanthangum production by fermentation from residueo fapple juice. Ciênc. Tecnol. Aliment., 27(1), 26-31.

[8] Elvas, A. B. C. (2016). Utilização de bagaço de maçã como ingrediente alimentar em iogurte com potencial efeito benéfico para a saúde. (Dissertação de Mestrado). Escola Superior Agrária do Instituto Politécnico de Viseu, Viseu, Portugal.

[9] Ferrandini, G. (2014). Avaliação do potencial antioxidante e produção de fermentado alcoólico a partir do bagaço da maçã. (Dissertação de mestrado). Universidade Tecnológica Federal do Paraná, Pato Branco.

[10] Ferreira, M. C.; Costa, S. M. L.; Pasin, L. A. A. (2015). Uso de resíduos da agroindústria de bananas na composição de substratos para produção de mudas de pau pereira. Nativa, Sinop, 3(2), 120-124.

[11] Fertonani, H. C. R., Scabio, A., Schemin, M. H. C., Carneiro, E. B. B., Nogueira, A. \& Wosiacki, G. (2006). Influência da concentração de ácidos no processo de extração e na qualidade de pectina de bagaço de maçã. Influence of acid concentration on extraction and quality of apple pomace pectin

[12] Semina: Ciências Agrárias, 27(4), 599-612.

[13] FiBL \& IFOAM - ORGANICS INTERNATIONAL. The World of Organic Agriculture. Statistics \& Emerging Trends 2017. http://www.organic-world.net/yearbook/yearbook-2017.html Acesso em 31 maio, 2019.

[14] FiBL \& IFOAM - ORGANICS INTERNATIONAL. The World of Organic Agriculture. Statistics \& Emerging Trends 2019. http://www.organic-world.net/yearbook/yearbook-2019.html. Acesso em 31 maio, 2019.

[15] IBGE - Instituto Brasileiro de Geografia e Estatística. (2013). Levantamento Sistemático da produção agrícola: pesquisa mensal de previsão e acompanhamento das safras agrícolas no ano civil. Rio de Janeiro: IBGE.

[16] Lima, P. C. C.; Souza, B. S.; Santini, A. T.; Oliveira, D. C. (2018). Aproveitamento agroindustrial de resíduos de mamão 'formosa' minimamente processados. Revista Agrogeoambiental, 10(3), 59-73.

[17] Malavolta, E., Haag, H. P., Mello, F. A. F., Brasil Sobrinho, M. O. C. (1974) Nutrição mineral e adubação de plantas cultivadas. São Paulo: Pioneira.

[18] Manrich, A.; Martins, M. A.; Pasqualoto, C.; Mattoso, L. H. C. (2017). Extração e caracterização de cutina de casca de maça. Emprapa Instrumentação. IX Workshop de Nanotecnologia Aplicada ao Agronegócio, São Carlos, 402405.

[19] Mazzoleni, E. M.\& Oliveira, L. G. de (2010). Inovação tecnológica na agricultura orgânica: estudo de caso da certificação do processamento pós-colheita. Rev. Econ. Sociol. Rural, 48(3).

[20] Nascimento Filho, W. B. do\&Franco, C. R. (2015). Avaliação do Potencial dos Resíduos Produzidos Através do Processamento Agroindustrial no Brasil. Revista Virtual de Química, 7(6).

[21] Oliveira, L.T., Veloso, J.C. R. \&Teran-Ortiz, G.P. (2009).Caracterização físico-química da farinha de semente e casca de uva.In Anais da II Semana de Ciência e Tecnologia do IFMG, Bambuí, Minas Gerais.

[22] OMS - Organização Mundial da Saúde. (2008). Substâncias químicas perigosas à saúde e ao ambiente. São Paulo: Cultura Acadêmica.

[23] Paganini, C., Alessandro Nogueira, A., Denardi, F.\&Wosiacki, G. (2004). Análise da aptidão industrial de seis cultivares de maçãs, considerando suas avaliações físico-químicas (dados da safra 2001/2002). Ciênc. agrotec., 28(6), 1336-1343.

[24] Schneider, V.E., Peresin, D.,Trentin, A.C., Bortolin, T. A. \& Sambuichi, R.H.R. (2012). Diagnóstico dos resíduos orgânicos do setor agrossilvo pastoril e agroindústrias associadas.Brasília: Instituto de Pesquisa Econômica Aplicada (IPEA). 
[25] SEAB - Secretaria de Estado da Agricultura e do Abastecimento.DERAL- Departamento de Economia Rural (2015). Fruticultura panorama mundial. emhttp://www.agricultura.pr.gov.br/arquivos/File/deral/Prognosticos/fruticultura_2014_15.pdf

[26] Sganzerla, E.,Martins, R. M. \& Singh, D. (2013).Alimentos orgânicos no Brasil: história, cultura e gastronomia.Curitiba: Esplendor.

[27] Shils, M. E., Olson, J. A., Shike, M. \& Ross, A. C. (2003). Tratado de nutrição moderna na saúde e na doença (9. ed). São Paulo: Manole.

[28] Silva F. M.; Pedroza, M. M.; Oliveira, L. R. A.; Colen, A. G. N.; Amaral, P. H. B. (2019). Rotas tecnológicas empregadas no aproveitamento de resíduos da indústria da soja. Revista Brasileira de Energias Renováveis, 8(1), 326363.

[29] Wosiacki, G. \& Nogueira, A. (2010). Suco de maçã. In: Venturini Filho, W. G. (Org.) Bebidas não alcoólicas:ciência e tecnologia: São Paulo: Blucher. 


\section{Capítulo 4}

Elaboração e perfil físico-químico e microbiológico de farinha de carcaça de tilápia do nilo (Oreochromis niloticus)

\section{Denise Pastore de Lima \\ Camila Gaio \\ Thays Scopel \\ Julianna Matias Vagula}

Resumo: Este trabalho teve como objetivo desenvolver farinha de carcaça de tilápia do Nilo (Oreochromis niloticus) e avaliar as características físico-químicas e microbiologias. As carcaças foram lavadas, cozidas, prensadas, moídas, secadas e novamente moídas para a obtenção da farinha. Foram realizadas análises de composição centesimal, cálcio, $\mathrm{pH}, \mathrm{Aw}$, cor e microbiológicas de contagem total de bactérias a 20oC e 35oC, coliformes a 35oC e 45oC, Escherichia coli, Estafilococos coagulase positiva e presença de Salmonella sp. As análises mostraram que a farinha de carcaça de tilápia apresentou resultados das análises físico-químicas e microbiológicas permitidos pela legislação e de acordo com os encontrados por outros autores. 0 produto se mostrou um alimento nutritivo e uma opção para o aproveitamento dos resíduos da filetagem da tilápia podendo ser utilizado na alimentação para humanos e animais.

Palavras-chave: resíduos; filetagem; alimentação humana. 


\section{INTRODUÇÃO}

A carne de tilápia apresenta boa aceitação no mercado consumidor por apresentar excelente qualidade, tornando-se apropriada para filetagem, sendo uma espécie de grande interesse para a piscicultura (BOSCOLO et al., 2001). A industrialização do pescado gera uma quantia significativa de resíduos que podem ser direcionados para várias modalidades de aproveitamento: alimentos para consumo humano e consumo animal, fertilizantes ou adubos orgânicos, produtos químicos e ainda aproveitá-los no desenvolvimento de produtos funcionais, entretanto a maior parte dos resíduos é destinada a produção de farinha (GONÇALVES, 2011). Os resíduos resultantes da industrialização dos pescados são superiores a $50 \%$, sendo que em alguns frigoríficos processadores de filé de tilápia tem-se entre 62,4 a $66,5 \%$ do peixe desperdiçado como resíduo (GOLÇALVES, 2011). A busca por alimentos mais nutritivos e a preservação do meio ambiente são tendências que vem crescendo na atualidade, razão pela preocupação com os subprodutos gerados no processamento (AZEVEDO et al., 2011). A farinha de peixe é pouco valorizada na nutrição humana, tendo-se poucos estudos diante desse assunto. 0 alto valor nutricional encontrado em sua composição agrega valor ao produto bem como incentiva a um desenvolvimento sustentável (GODOY et al., 2010). 0 objetivo do presente trabalho foi desenvolver farinha de carcaça de tilápia do Nilo (Oreochromis niloticus) e avaliar as características físico-químicas e microbiologias.

\section{MATERIAL E MÉTODOS}

A metodologia utilizada para a obtenção da farinha segue o processo descrito por Franco et al. (2013), com adaptações. As carcaças foram obtidas de um pesque e page localizado na região Oeste do Paraná, retirada as nadadeiras e resíduos de sangue, as mesmas foram cozidas em panela de pressão, por 60 minutos. Após, as carcaças foram prensadas, resultando numa torta, a qual foi triturada em um triturador Cutter Skymsen ${ }^{\circledR}$ (model PSEE98MHD). 0 produto triturado foi secado uma estufa Quimis ${ }^{\circledR}$ (modelo Q317B) a temperatura de $60^{\circ} \mathrm{C}$ por 24 horas. Após o produto foi moído em um moinho de facas SOLAB ${ }^{\circledR}$ (modelo CE-430/Mini) obtendo-se assim, a farinha de carcaça de tilápia, conforme mostra a Figura 1. A farinha foi embalada em embalagem plástica e mantida a temperatura ambiente até a realização das análises.

Figura 1 - Farinha de carcaça de tilápia

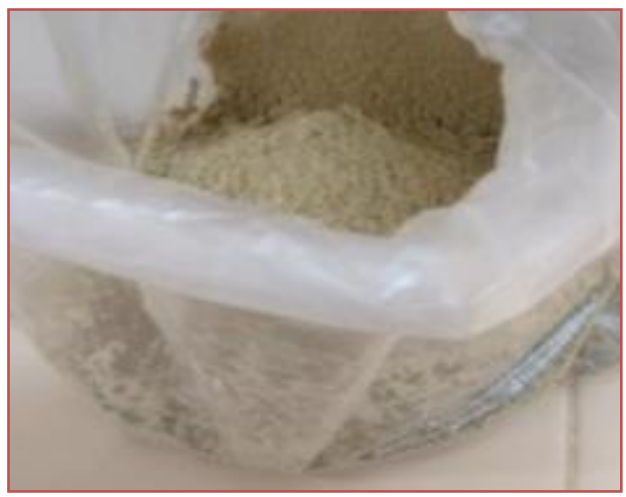

As medidas de $\mathrm{pH}$ foram realizadas sob temperatura ambiente utilizando potenciômetro (modelo $\mathrm{pH} 21$, Hanna $\left({ }^{\circledR}\right)$, homogeneizou-se $10 \mathrm{~g}$ de amostra com $50 \mathrm{~mL}$ de água destilada. Os teores de umidade, cinzas, lipídeos e proteína bruta foram determinados de acordo com procedimento descrito pela Association Official Analytical Chemists (2006). A análise de cálcio foi realizada seguindo metodologia do Compendio Brasileiro de Alimentação Animal (2009). Para a medida da cor foi utilizado o colorímetro Minolta ${ }^{\circledR}$ (modelo CR 400), com iluminante D65 e ângulo de visão de $10^{\circ}$. As medidas de cor foram realizadas em três diferentes pontos sobre o produto e expressas conforme o sistema de cor da Commission Internationale de L'Eclairage (CIELAB). A atividade de água (Aw) foi avaliada a $25 \mathrm{oC}$ em determinador de atividade de água Aqualab $®$ (modelo 4TE).

As análises microbiológicas de Coliformes a $45^{\circ} \mathrm{C}$ e $35^{\circ} \mathrm{C}$, Estafilolococcus coagulase positiva, Escherichia coli, Contagem bacteriana total a $20^{\circ} \mathrm{C}$ e a $35^{\circ} \mathrm{C}$ e presença de Samonella sp., foram realizadas, conforme Instrução Normativa no 62, do MAPA (BRASIL, 2003). Os resultados foram comparados com a legislação (BRASIL, 2001; ICMSF, 1982). 


\section{RESULTADOS E DISCUSSÃO}

A farinha de carcaça de tilápia apresentou resultados para proteína, umidade e cálcio próximo a pesquisa realizada por Galan et al. (2013), no mesmo produto (Tabela 1). Rocha et al. (2011) constatou em seu trabalho 9,43 a 9,91\% para lipídios em farinha de tilápia do Nilo, produzida artesanalmente para consumo humano, semelhantes ao obtido neste trabalho. Os valores encontrados para cinzas apresentaram-se semelhantes a Godoy (2006). Neiva (2008) encontrou pH de 6,77 para farinha de CMS de pescado cozida após secagem e Aw 0,36 para farinha mista de arroz e pescado, estando estes valores próximos aos encontrado para farinha de carcaça de tilápia. Coloração mais clara $\left(L^{*}\right)$, menor intensidade de vermelho $\left(a^{*}\right)$ e amarelo $\left(b^{*}\right)$ foi observado em farinha de carcaça, comprado com farinha de cabeça de tilápia (FUZINATTO et al., 2015).

Tabela 1 - Resultados das análises físico-químicas e instrumentais de farinha de carcaça de tilápia.

\begin{tabular}{|c|c|}
\hline Parâmetros & Farinha de carcaça de tilápia \\
\hline Proteína (\%) & $65,00 \pm 0,01$ \\
\hline Umidade (\%) & $2,15 \pm 0,40$ \\
\hline Cinzas (\%) & $25,15 \pm 0,14$ \\
\hline Lipídeos (\%) & $9,22 \pm 1,39$ \\
\hline Cálcio & $9,10 \pm 0,03$ \\
\hline Aw & $0,30 \pm 0,03$ \\
\hline pH & $6,80 \pm 0,14$ \\
\hline Cor L* & $75,44 \pm 0,17$ \\
\hline Cor a* & $0,46 \pm 0,05$ \\
\hline Cor b* & $22,49 \pm 0,19$ \\
\hline Os resultados estáo represt
\end{tabular}

Os resultados estão representados pela média \pm desvio padrão $(n=3)$

As enumerações de Coliformes a 35oC e 45oC, E. Coli e E. coagulase positiva não apresentaram contagens e não foi detectada a presença de Salmonella sp. na amostra de farinha (Tabela 2). As contagens total de bactérias a $20 \mathrm{oC}$ e a $35 \mathrm{oC}$ apresentaram valores permitidos pela legislação. Os resultados das análises microbiológicas atendem a legislação nacional e internacional (BRASIL, 2001; ICMSF, 1992).

Tabela 2 - Resultados das análises microbiológicas da farinha de carcaça de tilápia.

\begin{tabular}{|c|c|c|}
\hline Parâmetros & Resultado & Legislação \\
\hline Contagem de Coliformes a 35ํㅡ (NMP/g) & $<3,0$ & \\
\hline Contagem de Coliformes a 45ํㅡ (NMP/g) & $<3,0$ & $102^{*}$ \\
\hline Contagem de Escherichia coli (NMP/g) & $<3,0$ & $11^{* *}$ \\
\hline Contagem de Total de Bactéria a $20^{\circ} \mathrm{C}$ (Log.UFC/g) & $2,43 \pm 0,49$ & $5 \times 105^{* *}$ \\
\hline Contagem de Total de Bactéria a 35ํㅡ (Log.UFC/g) & $2,45 \pm 0,35$ & $5 \times 105^{* *}$ \\
\hline Contagem de Estafilococos coagulase Positiva (UFC/g) & $<102$ & $5 \times 102^{*}$ \\
\hline Presença de Salmonella sp. em $25 \mathrm{~g}$ & Ausência em $25 \mathrm{~g}$ & Ausência em $25 \mathrm{~g}$ \\
\hline
\end{tabular}

* BRASIL, (2001) ** ICMSF, (1982). Os resultados estão representados pela média \pm desvio padrão (n=3)

\section{CONCLUSÕES}

De acordo com os resultados físico-químicos e microbiológicos pode-se verificar que a farinha de carcaça de tilápia apresentou valores permitidos pela legislação e de acordo com os encontrados por outros 
autores sendo uma opção alimentar para animais e humanos. A farinha de carcaça se apresentou como um alimento nutritivo, uma opção para o aproveitamento do resíduo da filetagem da tilápia e podendo ajudar a preservar o meio ambiente.

\section{AGRADECIMENTOS}

Os autores agradecem à Universidade Tecnológica Federal do Paraná pelo apoio à realização deste estudo.

\section{REFERÊNCIAS}

[1] Association Methods of Analysis of AOAC International (2006)-Volume I and II, 18th Edition,(Rev. 1).

[2] Azevedo, F.L.A.A., Silva, A.D.F., Maciel, J.F., Moreira, R.T., Farias, L.R.G.(2011). Avaliação sensorial de pão de forma elaborado com soro de leite em pó. Revista Brasileira de Produtos Agroindustriais, Campina Grande, (13) 1, p.37-47.

[3] Boscolo, W.R.., Hayashi, C., Soares, C.M., Furuya, W.M., Meurer, F.(2001). Farinha de peixe, Carne e ossos, vísceras e crisálida como atractantes em dietas para alevinos de Tilápia do Nilo (Oreochromis niloticus). Rev. Bras. Zootec. (30) 5. Viçosa.

[4] Brasil, Agência Nacional de Vigilância Sanitária (2001). Regulamento Técnico Sobre Padrões de Microbiológicos para Alimentos. (Resolução RDC no 12, de 2 de janeiro de 2001). Diário Oficial da República Federativa do Brasil.

[5] Brasil, Ministério da Agricultura Pecuária e Abastecimento (2003). Oficializa os Métodos Analíticos Oficiais para Análises Microbiológicas para Controle de Produtos de Origem Animal e Água. Secretaria de Defesa Agropecuária. (Instrução normativa no 62, de 26 de agosto de 2003). Diário Oficial da República Federativa do Brasil.

[6] Franco, M.L.R.S., Abreu B.B., Saccomani, A.P.O., Vieira, V., Del Vesco, A.P., Mikcha, J.M.G., Gasparino, E., Adelbem, A. (2013). Elaboración de cookies y galletas con inclusión de harina de pescado. Infopesca Internacional. Montevideo, Uruguay. (53) 30-33.

[7] Fuzinatto, M.M., Lima, D.P., Andretto, A.P., Menezes, L.A., Souza, A.H.P., Franco, M.L.S., Steinmacher, N.C., Mendonça, S.N.T.G., Vargas, L. (2015). Influence of a homeopathic product on performance ando $\mathrm{n}$ quality flour and cookie (Grissini) of Nile tilapia. Afr. J. Pharm. Pharmacol. (9)675-683.

[8] Galan, G.L., Franco, M.L.R.S., Souza, E.D., Scapinello, C., Gasparino, E., Visentainer, J.V., Vesco, A.P.D. (2013). Farinha de carcaça de Tilápia em dietas para coelhos: composição química e resistência óssea. Semina: Ciências Agrárias, Londrina, (34)5 2473-2484.

[9] Godoy, L.C. (2006). Farinha de carcaça de peixe com ervas aromáticas para alimentação humana. Trabalho de conclusão de curso (Graduação em Zootecnia) - Universidade Estadual de Maringá, Maringá.

[10] Godoy, L.C., Franco, M.L.R.S., Franco, N.P., Silva, A.F., Assis, M.F., Souza, N.E., Matsushita, M., Visentainer, J.V. (2010). Análise sensorial de caldos e canjas elaborados com farinha de carcaças de peixe defumadas: aplicação na merenda escolar. Ciência Tecnologia de Alimentos, Campinas, 30(Supl.1): 86-89.

[11] Gonçalves, A.A. Tecnologia do pescado: Ciência, Tecnologia, Inovação e Legislação (2011). Editora Atheneu. São Paulo: Editora Atheneu, 608p.

[12] ICMSF. International Commission of Microbiological Specifications for Foods (1982). Microorganimsm in foods. Their significance and methods of enumeration. (2nd ed.) Universityof Toronto Press, Toronto. $436 \mathrm{p}$.

[13] Neiva, C.R.P. (2008). Processamento, avaliação nutricional e aceitabilidade de produtos à base de pescado desidratado: sopa e biscoito. Tese. Pós-graduação ao titulo de Doutor em Saúde Pública. Universidade de Saúde Pública de São Paulo- SP. 187 p.

[14] Rocha, J.B.C., Silveira, C.S., Ledo, C.A.S., Barreto, N.S.E. (2011). Composição e estabilidade de farinha de tilápia (Oreochromis niloticus) produzida artesanalmente para o consumo humano. Magistra, Cruz das Almas, (23)4, 215-220. 


\section{Capítulo 5}

\section{Avaliação sensorial e físico-química de mistura para}

preparo de cappucino a base de fontes proteicas do soro de leite

\section{Giovanna Mazoti Crubelati \\ Juliana Bueno Ruiz. \\ Suelen Pereira Ruiz Herrig}

Resumo: Derivados do soro de leite podem ser introduzidos em alimentos e bebidas, como soro de leite em pó, concentrado e isolado proteico. 0 objetivo deste trabalho foi substituir o leite em pó em mistura para preparo de cappuccino pelos derivados lácteos e avaliar a característica química e sensorial. 0 teste de aceitabilidade foi realizado por meio de escala hedônica e teste de preferência. Os parâmetros físico-químicos foram determinados como proteína pelo método de Kjeldahl, umidade pelo método de secagem em estufa, e pH utilizando um pHmetro digital. Os resultados da análise sensorial no teste de aceitação mostraram que ambas formulações foram aceitas pelos provadores, e no teste de preferência a formulação A foi mais preferida que a de referência. As análises físico-químicas apresentaram valores satisfatórios, como o aumento do teor de proteínas. Conclui-se que o objetivo foi alcançado e que os derivados lácteos podem ser empregados no desenvolvimento do produto.

Palavras-chave: aceitabilidade; concentrado; isolado; preferência. 


\section{INTRODUÇÃO}

0 poder poluente do soro de leite foi o que moveu governos e outras autoridades a restringir o escoamento do soro de leite não tratado. Mesmo confirmado suas potencialidades como matéria-prima, muitas indústrias ainda o consideram como resíduo e o descartam como um efluente (Baldissera et al., 2011). Por se tratar de um resíduo poluente, esforços se fazem necessários para transformar a quantidade de soro de leite gerada na indústria de laticínios em um produto adequado para consumo (Pescuma et al., 2010).

A proteína do soro é rica em aminoácidos essenciais de cadeia ramificada que favorecem o anabolismo, proporcionando o ganho de massa muscular (Haraguchi et al., 2006). Conforme Jervis et al. (2012), derivados do soro de leite, podem ser introduzidos em alimentos e bebidas, tais como o soro de leite em pó, com concentração de proteína de 11 a 14,5\%, o concentrado proteico, com teor proteico de 35 a $89 \%$ e a proteína isolada que contém, no mínimo, $90 \%$ de proteína em sua composição. Para Nishanthi et al. (2017), os concentrados de proteína de soro de leite são muito utilizados na indústria de alimentos devido às suas excelentes características funcionais.

De acordo Ziegler e Sgarbieri (2009), Patel (2015), o isolado proteico possui todos os aminoácidos essenciais, se tornando um ingrediente alimentar funcional e ativo cada vez mais conhecido. Com isso, o objetivo do trabalho foi substituir o leite em pó de mistura para preparo de cappuccino tradicional pelo soro de leite, o concentrado e o isolado proteico, determinando a melhor formulação para os mesmos, analisar a aceitabilidade por meio de análise sensorial, além de realizar parâmetros físico-químicos.

\section{MATERIAIS E MÉTODOS}

\subsection{FORMULAÇÃO DA MISTURA PARA PREPARO DE CAPPUCCINO}

Os ingredientes utilizados foram baseados na formulação padrão do Cappuccino tradicional industrializado. 0 leite foi substituído pelo soro de leite em pó (Formulação A), concentrado proteico (Formulação B) e o isolado proteico (Formulação C). 0 soro de leite em pó, o concentrado e o isolado proteico, foram fornecidos pela empresa "Alibra ingredientes LTDA" de Marechal Cândido Rondon - PR. Os demais ingredientes foram adquiridos no comércio local da cidade de Umuarama - PR. Os ingredientes estabelecidos em cada formulação para $50 \mathrm{~g}$ estão apresentados na Tabela 1.

Tabela 1 - Formulações das misturas para preparo de cappuccinos com soro, concentrado e isolado proteico do soro de leite.

\begin{tabular}{cc|c|c} 
Ingredientes & \multicolumn{2}{c|}{ Quantidade (g) } \\
Cacau em pó & Formulação A & Formulação B & Formulação C \\
Café Solúvel & 9,20 & 9,50 & 9,50 \\
Açúcar Light & 8,35 & 8,65 & 8,65 \\
Bicarbonato de Sódio & 8,00 & 8,00 & 2,00 \\
Canela em pó & 2,50 & 2,50 & 0,20 \\
Goma Xantana & 0,20 & 0,20 & - \\
Soro & 0,60 & - & - \\
Concentrado & 21,15 & - & 21,15 \\
Isolado & - & 21,15 & - \\
\hline
\end{tabular}

O valor energético (Kcal) para as formulações testadas foi determinado conforme a Resolução RDC no 360, de 23 de dezembro de 2003, para uma porção de 10 g. A quantidade de carboidratos, proteínas e gorduras totais foram obtidos por Franco (2008), Ribeiro e Benevides (2008) e pelo IBGE (2011). As composições do soro, o concentrado e o isolado proteico foram fornecidas pela Alibra (2017a,b,c). 


\subsection{ANÁLISE SENSORIAL}

Esta pesquisa foi submetida e aprovada pelo Comitê de Ética (CAAE: 66178217.0.0000.0104) em pesquisa da Universidade Estadual de Maringá (COPEP/UEM). Participaram da pesquisa provadores não treinados, de ambos os sexos, envolvendo estudantes, professores e funcionários. Os testes realizados foram de aceitação utilizando escala hedônica (Dutcosky, 2013) e o teste de preferência de comparação múltipla (Minim, 2013), desenvolvido no Laboratório de Análise Sensorial da UEM.

Nos testes sensoriais, as amostras foram servidas aleatoriamente aos julgadores em copos térmicos em temperatura de aproximadamente $70{ }^{\circ} \mathrm{C}$ e codificadas com 3 dígitos aleatórios. Participaram do teste de aceitação de escala hedônica, 103 provadores, e avaliaram as amostras em relação aos atributos: aroma, sabor e consistência, usando uma escala de nove pontos variando de 1 ("desgostei muitíssimo"), até 9 ("gostei muitíssimo).

No teste de preferência de comparação múltipla, 56 provadores participaram da análise sensorial. Foi apresentado aos julgadores a amostra referência (Cappuccino marca comercial) juntamente com as demais amostras a serem avaliadas. Os julgadores classificavam as amostras como de "igual preferência", "mais preferida" ou "menos preferida" que a referência, determinando também a intensidade da preferência como "nenhuma", "pequena", "moderada", "grande" ou "extrema", preenchendo a ficha de avaliação.

\subsection{ANÁLISES FÍSICO-QUÍMICAS}

Após a elaboração das formulações, as amostras foram caracterizadas em relação a proteína pelo método Kjeldahl, umidade pelo método de secagem em estufa a $105{ }^{\circ} \mathrm{C}$, e pH com uso de um pHmetro digital, seguindo os métodos do Instituto Adolfo Lutz (2008). Todas as análises foram realizadas em triplicata.

\subsection{ANÁLISE ESTATÍSTICA DOS DADOS}

Os resultados foram avaliados pela análise de variância (ANOVA) utilizando o teste de Tukey com o nível de significância de $5 \%(\alpha=0,05)$, com o auxílio do software Statistica ${ }^{\circledR}$ 8.0.

\section{RESULTADOS E DISCUSSÃO}

\subsection{FORMULAÇÃO DA MISTURA PARA PREPARO DE CAPPUCCINO}

Foi possível obter a mistura para o preparo de cappuccino substituindo o leite pelos derivados proteicos do soro de leite. A resolução que determinava os ingredientes básicos para o preparo do cappuccino era a Resolução RDC no 64, de 07 de julho de 2000 (ANVISA, 2000), porém ela foi revogada e substituída pela Resolução RDC no 273, de 22 de setembro de 2005 que aprova o "Regulamento Técnico para Misturas para Preparo de Alimentos e Alimentos Prontos para o Consumo" (ANVISA, 2005).

$\mathrm{O}$ valor energético (Kcal) para a porção de $10 \mathrm{~g}$ da mistura para o preparo de cappuccino da formulação $\mathrm{A}$, B, e C foi de 30,48 Kcal, 32,81 Kcal e 31,32 Kcal, respectivamente. Roberto et al. (2013), relatam que o cappuccino com leite possui 150 calorias, mostrando que as calorias nas misturas para o preparo de cappuccinos apresentam um valor inferior significativo.

\subsection{ANÁLISE SENSORIAL}

Os resultados médios obtidos no teste de aceitação são apresentados na Tabela 2. Nota-se que a formulação A apresentou uma melhor aceitação em relação às formulações B e C. 
Tabela 2 - Resultados médios das notas atribuídas para cada formulação na mistura para preparo de cappuccino no teste de aceitação.

\begin{tabular}{|c|c|c|c|}
\hline Atributos & Formulação A & Formulação B & Formulação C \\
\hline $\begin{array}{c}\text { Aroma } \\
\text { Sabor } \\
\text { Consistência } \\
\text { Intenção de compra }\end{array}$ & $\begin{array}{l}7,02 \pm 1,15 a \\
7,06 \pm 1,08 \mathrm{a} \\
7,16 \pm 1,25 \mathrm{a} \\
3,83 \pm 0,90 \mathrm{a}\end{array}$ & $\begin{array}{c}6,99 \pm 1,18 a \\
6,70 \pm 1,18 a b \\
6,58 \pm 1,26 b \\
3,39 \pm 0,95 b\end{array}$ & $\begin{array}{l}6,82 \pm 1,31 \mathrm{a} \\
6,54 \pm 1,27 \mathrm{~b} \\
6,26 \pm 1,34 \mathrm{~b} \\
3,14 \pm 0,93 \mathrm{~b}\end{array}$ \\
\hline
\end{tabular}

Letras iguais na mesma linha indicam não haver diferença significativa entre si pelo teste de Tukey a $5 \%$ de significância.

No atributo aroma, não houve diferença significativa entre as formulações. Apesar dos derivados lácteos substituídos pelo leite serem ingredientes diferentes, os mesmos não interferiram nesse atributo. No atributo sabor houve diferença significativa entre as formulações A e C. 0 mesmo pode ser justificado pela diferença da quantidade de proteínas que possui o soro e o isolado proteico. Os dados do presente trabalho estão semelhantes com os de Kikuta et al. (2015), que desenvolveram um mix nutricional em gel no sabor de cappuccino com adição do isolado proteico, e relataram uma média para o aroma de 7,42 e o sabor 6,58.

No atributo consistência, o único que se diferenciou foi a formulação A, podendo ser sugerido pela adição da goma xantana. De acordo com Nery e Brandão (2008), a goma xantana possui capacidade de alterar as propriedades básicas da água como espessante, estabilizante de emulsões, suspensão, geleificação. Brino et al. (2010), no preparo do cappuccino substituindo o leite por soro de leite obtiveram uma média de aceitação para o aroma de 6,53, para o sabor 6,87 e para a consistência 6,97. Isso mostra que os valores das médias obtidos na pesquisa estão próximos dos autores.

Em relação ao teste de preferência de comparação múltipla, os resultados são mostrados na Tabela 3. A formulação A (mais preferida que R) se diferenciou das formulações B e C (preferida igual a R) tanto para o aspecto tipo de preferência como para a intensidade de preferência, mostrando ser mais preferida que a de referência.

Tabela 3 - Média das notas atribuídas para cada formulação na mistura para preparo de cappuccino no teste de preferência.

\begin{tabular}{|c|c|c|c|}
\hline & Formulação A & Formulação B & Formulação C \\
\hline $\begin{array}{l}\text { Tipo de Preferência } \\
\text { Intensidade de Preferência }\end{array}$ & $\begin{array}{l}1,77 \pm 0,66 a \\
3,70 \pm 0,73 a\end{array}$ & $\begin{array}{l}2,14 \pm 0,61 b \\
3,23 \pm 0,87 b\end{array}$ & $\begin{array}{l}2,13 \pm 0,63 b \\
3,20 \pm 0,80 b\end{array}$ \\
\hline
\end{tabular}

Letras iguais na mesma linha indicam não haver diferença significativa entre si pelo teste de Tukey a $5 \%$ de significância.

A formulação A além de apresentar uma melhor preferência, contem ingrediente soro de leite com custo comercial inferior ao concentrado e isolado protéico, e também inferior ao leite utilizado nos cappuccinos tradicionais. Comparando-se os resultados para as formulações B e C, não houve diferença entre si, mostrando ser produtos que também serão aceitos no mercado, pois apresentaram uma preferência igual a de referência.

\subsection{ANÁLISES FÍSICO-QUÍMICAS}

Os resultados das análises físico-químicas apresentados na Tabela 4 mostraram que houve diferença significativa entre as formulações.

Tabela 4 - Valores físico-químicos das formulações na mistura para preparo de cappuccino.

\begin{tabular}{|c|c|c|c|}
\hline Análises & Formulação A & Formulação B & Formulação C \\
\hline $\begin{array}{c}\text { Proteína (\%) } \\
\text { Umidade (\%) } \\
\text { pH }\end{array}$ & $\begin{array}{c}12,32 \pm 0,24 c \\
2,75 \pm 0,06 c \\
7,74 \pm 0,08 a\end{array}$ & $\begin{array}{c}31,69 \pm 0,33 b \\
3,96 \pm 0,03 b \\
7,28 \pm 0,08 b\end{array}$ & $\begin{array}{c}35,21 \pm 0,59 a \\
3,75 \pm 0,00 a \\
7,35 \pm 0,09 b\end{array}$ \\
\hline
\end{tabular}

Letras iguais na mesma linha indicam não haver diferença significativa entre si pelo teste de Tukey a $5 \%$ de significância. 
Mesmo a formulação A apresentando uma quantidade menor de proteínas, o leite utilizado nos cappuccinos tradicionais apresenta uma quantidade ainda menor de proteínas. Segundo Walstra et al. (2006) o leite possui em média 3,25\% de proteínas. Desta forma, os derivados do soro, apresentam uma maior contribuição no valor proteico em relação ao leite. Em estudos realizados por Henrique et al. (2012), no desenvolvimento de formulações de sobremesas lácteas com soro de queijo e maracujá, houve um aumento de proteínas na formulação com soro de leite $(13,02 \%)$ em relação a formulação que não incluía o soro de leite $(11,26 \%)$, corroborando com o valor obtido no presente estudo.

Em relação ao teor de umidade, houve diferença significativa entre as formulações. A formulação A apresentou uma porcentagem menor em relação às formulações B e C. Segundo Alibra (2017a,b,c), o soro possui em suas características físico-químicas um máximo de 3\% de umidade, o concentrado máximo de $5,5 \%$ e o isolado máximo de 4,5\%, isso explica o resultado obtido.

Os valores de pH obtidos, estão de acordo com o estudo dos autores Brino et al. (2010) que identificaram um pH igual a 7,36 no preparo do cappuccino substituindo o leite por soro de leite.

\section{CONCLUSÕES}

No desenvolvimento da mistura para preparo de cappuccino, foi possível obter uma formulação com a presença dos derivados do soro. Nas análises sensoriais, todas as amostras apresentaram uma boa aceitação sensorial frente aos provadores. No teste de preferência, a formulação A mostrou ser mais preferida que a de referência, no entanto as formulações B e C também podem ser aceitas no mercado. Nas análises físico-químicas os resultados obtidos foram satisfatórios, uma vez que houve o aumento do teor de proteína, contribuindo com valor nutricional e comercial do produto.

\section{REFERÊNCIAS}

[1] Alibra, Ingredientes. (2017a). Especificações Técnicas, Alibra CL 3987: Composto Lácteo. Campinas: ALIBRA, (Relatório Técnico).

[2] Alibra, Ingredientes. (2017b). Especificações Técnicas, Alibra CL 3985: Composto Lácteo. Campinas: ALIBRA, (Relatório Técnico).

[3] Alibra, Ingredientes. (2017c) Especificações Técnicas, Alibra SW 1108: Soro de Leite em Pó. Campinas: ALIBRA, (Relatório Técnico).

[4] Baldissera, A. C., Betta, F. D., Penna, A. L. B., \& Lindner, J. D. (2011). Alimentos funcionais: uma nova fronteira para o desenvolvimento de bebidas proteicas a base de soro de leite. Semina Ciências Agrárias, 32(2), 1497-1512.

[5] Brasil, Ministério da Saúde (2003). Agência Nacional de Vigilância Sanitária. Resolução RDC no 360, de 23 de dezembro de 2003. Regulamento Técnico sobre Rotulagem Nutricional de Alimentos Embalados.

[6] Brasil, Ministério da Saúde (2005). Agência Nacional de Vigilância Sanitária. Resolução RDC no 273, de 22 de setembro de 2005. Regulamento Técnico para Misturas para Preparo de Alimentos e Alimentos Prontos para o Consumo.

[7] Brino, L. C., Madrona, G. S., \& Terra, C. O. (2010). Substituição do Leite em pó pelo Soro de Leite em pó na produção de Capuccino. Revista em Agronegócios e Meio Ambiente, 3(2), 147-156.

[8] Dutcosky, S. D. (2013). Análise Sensorial de Alimentos. Curitiba: Champagnat.

[9] Franco, G. (2008). Tabela de Composição Química dos Alimentos. São Paulo, SP: Atheneu.

[10] Haraguchi, F. K., Abreu, W. C., \& Paula, H. (2006). Proteínas do soro do leite: composição, propriedades nutricionais, aplicações no esporte e benefícios para a saúde humana. Rev. Nutr., 19(4), 479-488.

[11] Henrique, J. R., Henrique, J. R., Rodrigues, L. M. A., Paixão, M. G., Pinto, S. A., \& Paciulli, S. 0. D. (2012). Desenvolvimento, Parâmetros Físico-Químicos e Avaliação Sensorial de Sobremesas Lácteas produzidas com diferentes variedades de Maracujá com e sem Soro de Leite. Revista do Instituto de Laticínios Cândido Tostes, 389 (67), 27-33.

[12] Instituto Adolfo Lutz. (2008). Métodos físico-químicos para análise de alimentos. São Paulo: Instituto Adolfo Lutz.

[13] Instituto Brasileiro de Geografia e Estatística - IBGE. (2011). Tabelas de Composição Nutricional dos Alimentos Consumidos no Brasil. Rio de Janeiro, RJ. 
[14] Jervis, S., Campbell, R., Wojciechowski, K. L., Foegeding, E. A., Drake, M. A., \& Barbano, D. M. (2012). Effect of bleaching whey on sensory and functional properties of $80 \%$ whey protein concentrate. Journal of Dairy Science, 95(6), 2848-2862.

[15] Kikuta, J. F., Gazelotto, S., Scapim, M. R. S., \& Madrona, G. S. (2015). Desenvolvimento de Mix Nutricional em gel para Atletas. Revista Tecnológica, 337-345.

[16] Minim, V. P. R. (2013). Análise Sensorial Estudos com Consumidores. Viçosa: UFV.

[17] Nery, T. B. R., \& Brandão, L. V. (2008). Biossíntese de Goma Xantana a partir da Fermentação de Soro de Leite: Rendimento e Viscosidade. Química 1937-1941. Nishanthi, M., Chandrapala, J., \& Vasiljevic, T. (2017). Properties of whey protein concentrate powders obtained by spray drying of sweet, salty and acid whey under varying storage conditions. Journal of Food Engineering, 214, 137146.

[18] Patel, S. (2015). Functional food relevance of whey protein: A review of recent findings and scopes ahead. Journal of Functional Foods, 19, 308-319.

[19] Pescuma, M., Hébert, E. M., Mozzi, F., \& Valdez, G. F. (2010). Functional fermented whey-based beverage using lactic acid bacteria. International Journal of Food Microbiology, 141(1-2), 73-81.

[20] Ribeiro, C. G \& Benevides, K. S. (2008). Tabela Centesimal de Alimentos Diet \& Light. São Paulo: Atheneu.

[21] Roberto, C. A., Haynos, A. F., Schwartz, M. B., Brownell, K. D., \& White, M. A. (2013). Calorie estimation accuracy and menu labeling perceptions among individuals with and without binge eating and/or purging disorders. Official Journal of the Italian Society for the Study of Eating Disorders (SISDCA), 18(3), 255-261.

[22] Walstra, P., Wouters, J. T. M., \& Geurts, T. J. (2006). Dairy Science and Technology. Boca Raron: CRC Press.

[23] Ziegler, F. L. F., \& Sgarbieri, V. C. (2009). Caracterização químico-nutricional de um isolado proteico de soro de leite, um hidrolisado de colágeno bovino e misturas dos dois produtos. Revista de Nutrição, 22(1), 61-70. 


\section{Capítulo 6}

Efeito do branqueamento sobre as características físico-químicas e microbiológicas em acerolas (Malpighia punicifolia DC)

\section{Luis Eduardo Silva Nascimento \\ Fernanda Vanessa Netto Aragão \\ Mirla de Nazaré do Nascimento Miranda \\ Silvana Neves de Melo}

Resumo: 0 branqueamento pode ser considerado como um pré-tratamento para auxiliar na durabilidade do alimento. Este trabalho teve por objetivos avaliar os processos de branqueamento por imersão e a vapor, bem como suas interferências sobre as características físico-químicas e microbiológicas dos frutos de acerola. Avaliadas de acordo com o planejamento fatorial 23. As variáveis independentes foram tipo de branqueamento (imersão e vapor), o tempo (1 e $3 \mathrm{~min}$ ) e a temperatura (70 e $90^{\circ} \mathrm{C}$ ) de processamento. Os resultados das análises físico-químicas após branqueamento, comparados aos valores do fruto in natura sofreram poucas alterações. Enquanto para análises microbiológicas, ambos os tratamentos térmicos foram eficientes, apresentando ausência de salmonela sp. e coliformes a $45 \stackrel{\text { o }}{\mathrm{C}}$ para todas as amostras.

Palavras-chave: branqueamento a vapor; branqueamento por imersão; caracterização. 


\section{INTRODUÇÃO}

A acerola é considerada uma fruta tropical de grandes potencialidades econômicas e nutricionais, podendo ser utilizada como matéria-prima para diversos produtos alimentícios (Agostini-Costa et al., 2003; Neves, 2009; Bicas et al., 2011). Entretanto, Mercali (2013) ressalta que ela apresenta alta perecibilidade, e por isso requer atenção quanto ao seu processamento e consequentemente conservação de seus constituintes nutricionais, onde a otimização do processo do tratamento térmico do branqueamento pode vir a minimizar as alterações decorrentes.

O branqueamento consiste em um tratamento térmico, sendo aplicado para minimizar alterações sensoriais e nutricionais. Entretanto, as alterações físico-químicas dependem do tempo de exposição e do meio (água ou vapor) utilizado para transmissão de calor durante o processo (Correia et al., 2008). Além disso, o branqueamento também reduz a carga microbiana inicial do produto, promove o amaciamento de tecidos vegetais, facilitando o envase, e remove o ar dos espaços intercelulares, no caso de vegetais enlatados (Azeredo, 2004).

A maioria dos processos de preparação e conservação de alimentos conta com a aplicação ou a remoção de calor, sendo que o uso de temperaturas altas é importante para a destruição de patógenos e microorganismos deteriorantes, melhorando tempo de vida de prateleira do alimento. Segundo Furtado e Silva (2005) este fator é importante tanto na etapa de processamento, como na etapa de estocagem do produto.

Assim, aplicou-se a otimização do processo de branqueamento, como forma de verificar em qual binômio tempo/temperatura as características físico-químicas da acerola são menos afetadas e também para analisar o efeito do calor na destruição de microrganismos presentes.

\section{MATERIAL E MÉTODOS}

As amostras utilizadas foram adquiridas na feira da Ceasa do município de Castanhal-PA, acondicionadas em caixas isotérmicas refrigeradas e conduzidas ao laboratório de Alimentos do Centro de Ciências Naturais e Tecnologia da UEPA para a realização das análises físico-químicas e microbiológicas.

\subsection{PREPARO DAS AMOSTRAS}

Foram selecionados, lavados em água corrente e sanitizados em solução de hipoclorito de sódio a 20ppm. Sendo utilizados cerca de $100 \mathrm{~g}$ de acerola para cada ensaio e separadas para serem submetidas ao branqueamento e algumas amostras in natura para realização das análises de composição centesimal e análises microbiológicas. Completando $2 \mathrm{~kg}$ de matéria-prima para a realização de todas as análises.

\subsection{BRANQUEAMENTO POR VAPOR E POR IMERSÃO}

0 processo de branqueamento foi realizado utilizando um banho maria Logen modelo LSA04B-SN-0220. Os parâmetros foram estabelecidos de acordo com o planejamento experimental do tipo fatorial $2^{3}$ com repetições do ponto central, totalizando 14 ensaios. Os níveis (Tabela 1) das variáveis avaliadas foram: tempo ( 1 e $3 \mathrm{~min}$ ), temperatura ( 70 e $90^{\circ} \mathrm{C}$ ) e o tipo de branqueamento (a vapor ou por imersão).

Tabela 1 - Planejamento experimental $2^{3}$.

\begin{tabular}{|c|c|c|c|}
\hline FATORES & $(-)$ & NÍVEIS $(0)$ & $(+)$ \\
\hline Branqueamento & Imersão & - & Vapor \\
\hline Tempo $(\mathrm{min})$ & 1 & 2 & 3 \\
\hline Temperatura $\left(^{\circ} \mathrm{C}\right)$ & 70 & 80 & 90 \\
\hline
\end{tabular}

\subsection{ANÁLISES FÍSICO-QUÍMICAS}

Todas as análises físico-químicas realizadas seguiram a metodologia proposta pelo Instituto Adolpho Lutz (2008). Para a obtenção da composição centesimal (umidade, cinzas, carboidratos, proteínas e lipídios) foram utilizados frutos in natura. Entretanto, para avaliar o efeito do branqueamento de acordo com o 
planejamento experimental foram analisados os resultados de $\mathrm{pH}$, sólido solúveis totais e acidez total titulável.

\subsection{ANÁLISES MICROBIOLÓGICAS}

As análises para coliformes a $45^{\circ} \mathrm{C}$ e Salmonella sp, foram realizadas segundo a metodologia proposta por Vanderzant e Splittstoesser (1992). Os resultados foram analisados segundo a Resolução da Agência Nacional da Vigilância Sanitária - ANVISA (2001) e expressos em ausente ou presente para Salmonella sp e NMP/g para coliformes a $45^{\circ} \stackrel{\circ}{ }$.

\section{RESULTADOS E DISCUSSÃO}

Os resultados da caracterização físico-química das amostras do fruto in natura podem ser observados na Tabela 2. Comparando-se os resultados obtidos aos padrões de identidade e qualidade para a polpa de acerola, estabelecidos na Instrução Normativa no 1, de 07 de janeiro de 2000 do Ministério da Agricultura, Pecuária e Abastecimento (MAPA), verificou-se que a amostra avaliada apresentou parâmetros em acordo com os limites mínimos estabelecidos.

Para o teor de sólidos solúveis a legislação vigente preconiza como valor mínimo 5,5 Brix para polpa de acerola, o mesmo valor foi encontrado nas amostras em estudo. Quanto ao $\mathrm{pH}$, as amostras situaram-se acima do padrão mínimo de 2,8. Assim como para a acidez (0,93 \%) e sólidos totais (9,01\%), estando todos dentro dos parâmetros estabelecidos pela legislação.

Os resultados para $\mathrm{pH}$, sólidos solúveis totais e acidez total titulável para os tratamentos térmico (branqueamento a vapor e por imersão) de acordo com o planejamento experimental estão na Tabela 3. Os resultados da estimativa dos efeitos padronizados estão apresentados nas figuras 1, 2 e 3 com o valor p, indicando os fatores mais influentes sobres as respostas teores de acidez total titulável (ATT), sólidos solúveis totais (SS) e pH dentro de um intervalo de confiança de 95\%.

Tabela 2 - Caracterização físico-química da acerola in natura.

\begin{tabular}{|c|c|c|}
\hline Análises & Valores médios & $\begin{array}{c}\text { Parâmetros } \\
\text { (MAPA, 2000) }\end{array}$ \\
\hline Acidez em ácido cítrico (\%) & $0,93 \pm 0,02$ & 0,80 \\
\hline $\mathrm{pH}$ & $3,65 \pm 0,05$ & 2,80 \\
\hline BRIX & $5,5 \pm 0,10$ & 5,5 \\
\hline Sólidos totais (\%) & $9,01 \pm 0,41$ & 6,50 \\
\hline Umidade (\%) & $90,99 \pm 0,41$ & \\
\hline Proteínas (\%) & $0,80 \pm 0,06$ & \\
\hline Lipídeos (\%) & $0,18 \pm 0,03$ & \\
\hline Cinzas (\%) & $0,36 \pm 0,02$ & \\
\hline Carboidratos (\%) & 7,67 & \\
\hline
\end{tabular}

De acordo com os resultados obtidos, a variável de resposta sólidos solúveis não apresentou influência significativa nas variáveis estudadas como o tipo de branqueamento, tempo e temperatura, dentro do intervalo de confiança de 95\%. Segundo Chitarra e Chitarra (2005) o teor de sólidos solúveis é um dos indicativos da quantidade de açúcares presente nos frutos, pois há outras substâncias como vitaminas, ácidos, aminoácidos e algumas pectinas, que também influenciam este parâmetro. 
Tabela 3 - Teores de acidez total titulável, sólidos solúveis totais e pH nas amostras in natura e branqueadas.

\begin{tabular}{|c|c|c|c|c|c|c|c|}
\hline \multirow[b]{2}{*}{ Ensaios } & \multicolumn{3}{|c|}{ Variáveis independentes } & \multicolumn{4}{|c|}{ Variáveis de respostas } \\
\hline & Branqueamento & $\begin{array}{l}\text { Tempo } \\
\text { (min) }\end{array}$ & $\begin{array}{c}\text { Temperatura } \\
\left({ }^{\circ} \mathrm{c}\right)\end{array}$ & $\begin{array}{l}\text { Sólidos } \\
\text { solúveis }\end{array}$ & $\mathrm{pH}$ & $\begin{array}{l}\text { Acidez } \\
\text { titulável }\end{array}$ & $\begin{array}{l}\text { Relação } \\
\text { SST/ATT }\end{array}$ \\
\hline 1 & Imersão & 1 & 70 & 5,35 & 3,37 & 0,89 & 6,29 \\
\hline 2 & Vapor & 1 & 70 & 4,60 & 3,72 & 0,82 & 5,61 \\
\hline 3 & Imersão & 3 & 70 & 5,30 & 3,43 & 0,71 & 10,39 \\
\hline 4 & Vapor & 3 & 70 & 5,00 & 3,78 & 0,76 & 7,94 \\
\hline 5 & Imersão & 1 & 90 & 5,30 & 3,38 & 0,82 & 6,46 \\
\hline 6 & Vapor & 1 & 90 & 4,60 & 3,65 & 0,80 & 6,05 \\
\hline 7 & Imersão & 3 & 90 & 5,15 & 3,46 & 0,63 & 8,17 \\
\hline 8 & Vapor & 3 & 90 & 5,00 & 3,67 & 0,72 & 6,58 \\
\hline $9(\mathrm{C})$ & Imersão & 2 & 80 & 5,30 & 3,50 & 0,73 & 7,26 \\
\hline $10(\mathrm{C})$ & Vapor & 2 & 80 & 5,50 & 3,65 & 0,76 & 7,24 \\
\hline $11(\mathrm{C})$ & Imersão & 2 & 80 & 5,40 & 3,45 & 0,70 & 7,71 \\
\hline $12(\mathrm{C})$ & Vapor & 2 & 80 & 6,20 & 3,68 & 0,73 & 8,49 \\
\hline $13(\mathrm{C})$ & Imersão & 2 & 80 & 5,20 & 3,46 & 0,76 & 6,84 \\
\hline $14(\mathrm{C})$ & Vapor & 2 & 80 & 5,00 & 3,62 & 0,76 & 6,58 \\
\hline
\end{tabular}

SST: Sólidos solúveis totais, expressos em Brix; ATT: Acidez total titulável, em g de ácido cítrico 100 mL-1 de amostra; C: Ponto Central.

Observou-se que o $\mathrm{pH}$ das amostras foi influenciado apenas pelo tipo de branqueamento. De acordo com o efeito estimado, quando o branqueamento aplicado foi por imersão, houve uma redução em média de 0,25 no valor do pH das amostras. Lima et al. (2002) afirma que o pH é um parâmetro de baixa variabilidade em acerolas, mesmo nas maduras, esse comportamento pode ser explicado pelo fato dos ácidos orgânicos, que se encontram dentro dos vacúolos, apresentarem a função de manter o pH da célula ao se combinarem com sais e formarem um sistema tamponante nos frutos cítricos.

Os resultados apresentados indicaram que as amostras que passaram pelo processamento térmico, não sofreram mudanças suficientes para descaracterizar o pH normalmente encontrado na fruta de acordo com a literatura, pois segundo Freitas et al. (2006) o pH da acerola encontra-se na faixa de 2,58 a 3,91.

Para a resposta acidez total titulável as variáveis que influenciaram foram o tempo e a temperatura de processamento e as interações entre o tempo e o tipo de branqueamento. À medida que o tempo de branqueamento passou de 1 para $3 \mathrm{~min}$, houve uma redução em média de 0,13 no valor da acidez titulável. A relação SST/ATT apresentou comportamento similar.

0 teor de acidez diminuiu à medida que aumentou o tempo de exposição da fruta ao aquecimento, o que pode ter sido devido, segundo Maia et al. (2007), à degradação dos ácidos (ácido cítrico, ácido málico, ácido ascórbico) naturalmente presentes na constituição dos frutos de acerola.

As análises microbiológicas de Salmonella sp. e contagem de coliformes a $45 \stackrel{\circ}{\circ}$ foram realizadas sem e com o tratamento térmico de acordo com planejamento fatorial (Tabela 1), com a finalidade de avaliar se foram efetivos para esses parâmetros microbiológicos.

Os resultados encontrados para Salmonella sp. apresentaram-se de acordo com a RDC no 12 , de 2 de janeiro de 2001(ANVISA, 2001), a qual estabelece ausência de Salmonella sp./25g de amostra. Para as amostras in natura e sanitizadas os resultados das análises para coliformes a $45^{\circ} \mathrm{C}$ foi $2,3 \mathrm{NMP} / \mathrm{g}$. Os demais ensaios não apresentaram contaminação por coliformes, logo, é possível afirmar que os dois métodos de branqueamentos foram eficientes independentes do tempo e temperatura.

O branqueamento das frutas contribuiu para a redução da carga microbiana. Que podem ser oriundas de duas fontes de contaminações, primárias e secundárias. Sendo as primárias: insetos, contato com o solo e outros, e as secundárias: embalagens, equipamentos, forma de colheita ou manipulação dos frutos. 
Figura 1 - Estimativas dos efeitos padronizados das variáveis de resposta sólidos solúveis (SS).

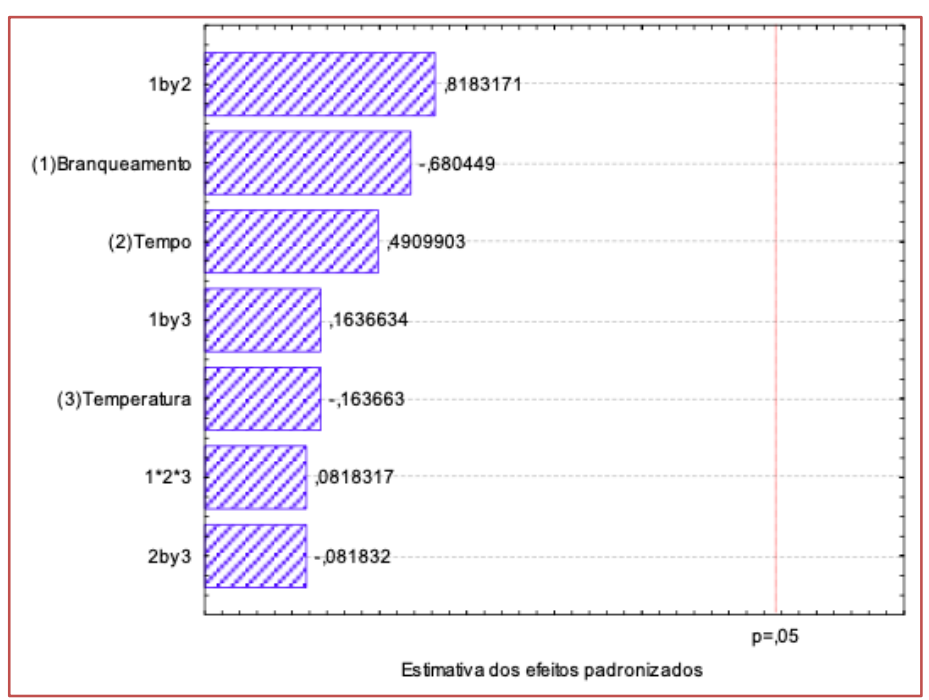

Figura 2 - Estimativas dos efeitos padronizados das variáveis de resposta $\mathrm{pH}$.

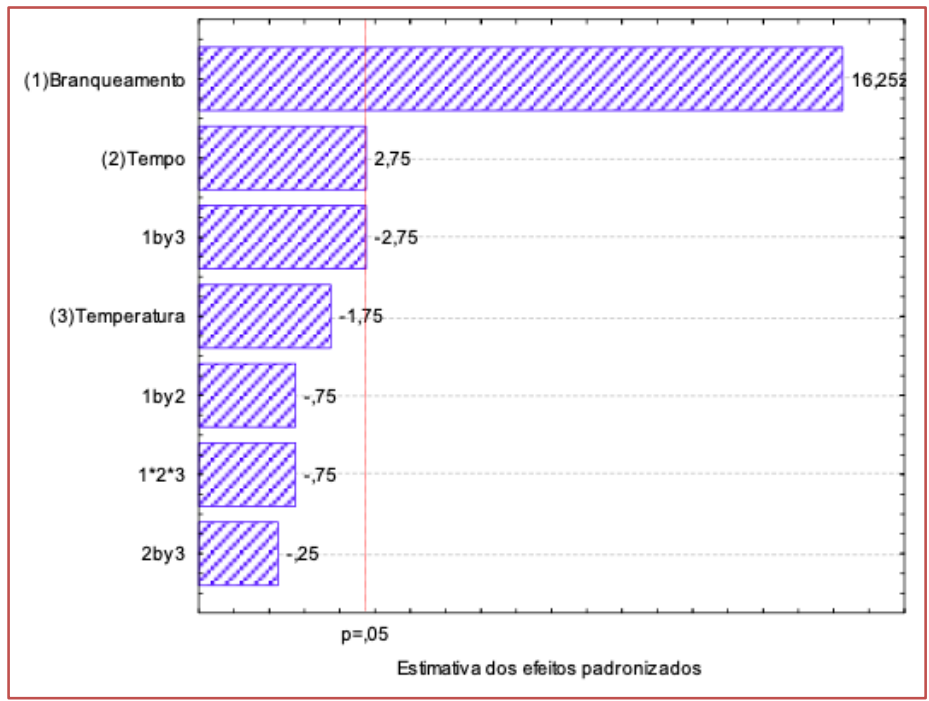

Figura 3 - Estimativas dos efeitos padronizados das variáveis de resposta acidez titulável (ATT).

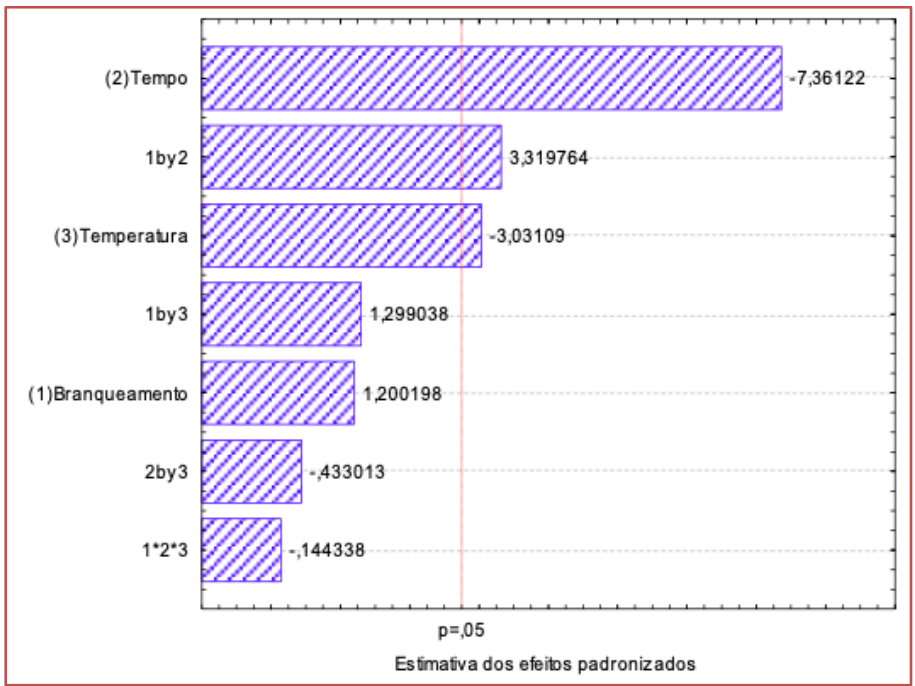




\section{CONCLUSÕES}

Os resultados das análises físico-químicas após branqueamento, comparados aos valores do fruto in natura sofreram poucas alterações. As perdas de acidez durante o processamento estão associadas à degradação térmica, pelo efeito do calor durante o branqueamento. No entanto, o branqueamento por imersão teve um efeito maior na degradação da acidez do que no branqueamento por vapor. Para análises microbiológicas, ambos os tratamentos térmicos foram eficientes, apresentando ausência de salmonela sp. e resultado inferior a 3 para coliformes a $45^{\circ} \mathrm{C}$ para todas as amostras branqueadas. Portanto, os parâmetros avaliados que são tipos de branqueamento, tempo e temperatura não descaracterizaram os padrões físico-químicos e nutricionais para as amostras de acerola estudada.

\section{REFERÊNCIAS}

[1] AGOSTINI-COSTA, T. S., ABREU, L. N., ROSSETTI, A. G. (2003). Efeito do congelamento e do tempo de estocagem de polpa de acerola sobre o teor de carotenoides. Revista Brasileira de Fruticultura, 25, 56-58.

[2] AZEREDO, H. M. C. (2004). Fundamentos de estabilidade de alimentos. Fortaleza: Embrapa Agroindústria Tropical.

[3] BICAS, J. L., MOLINA, G., DIONÍSIO, A. P., BARROS, F. F. C., WAGNER, R., MARÓSTICA JUNIOR, M. R., PASTORE, G. M. (2011). Volatile constituents of exotic fruits from Brazil. Food Research International, 44(7), 1843-1855.

[4] BRASIL, Agência Nacional de Vigilância Sanitária.Regulamento técnico sobre padrões microbiológicos para alimentos. (Resolução RDC no 12, de 02 de janeiro de 2001). Diário Oficial da União.

[5] BRASIL, Ministério da Agricultura, Pecuária e Abastecimento. (2000). Aprova Regulamento Técnico para fixação dos Padrões de Identidade e Qualidade para polpa de fruta. (Instrução Normativa № 1, de 07 de janeiro de 2000).

[6] CHITARRA, A.B., CHITARRA, M.I.F. (2005).Pós-colheita de frutos e hortaliças: fisiologia e manuseio. Lavras:

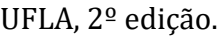

[7] CORREIA, L. F. M., FARAONI, A. S., PINHEIRO-SANT'ANA, H. P. (2008). Efeitos do processamento industrial de alimentos sobre a estabilidade de vitaminas. Alimentos e Nutrição, 19(1), 83-95.

[8] FREITAS, C. N. S., MAIA, G. A., COSTA, J. M. C., FIGUEIREDO, R. W., SOUSA, P. H. M. (2006). Acerola: Produção, composição, aspectos nutricionais e produtos. Revista Brasileira de Agrociência, Pelotas, 12(4), 395-400.

[9] FURTADO, A. A. L., SILVA, F. T. (2005). Manual de Processamento de Conserva de Pimenta. Rio de Janeiro: Embrapa Agroindústria de Alimentos.

[10] INSTITUTO ADOLFO LUTZ (2008). Métodos físico-químicos para análise de alimentos. 4ª̣ed. São Paulo.

[11] LIMA, V.L.A.G., MUSSER, R.S., LEMOS, M.A. (2002). Análise conjunta das características físico-químicas de acerola (Malpighia emarginata D.C.) do banco ativo de germoplasma em Pernambuco. In anais do XVII Congresso Brasileiro de Fruticultura, Belém, Brasil.

[12] MAIA, G. A., SOUSA, P. H. M., SANTOS, G. M., SILVA, D. S., FERNANDES, A. G., PRADO, G. M. (2007). Efeito do processamento sobre componentes do suco de acerola. Ciência e Tecnologia de Alimentos, 27(1): 130-134.

[13] MERCALI, G. D. (2013). Tratamento térmico de polpa de acerola via aquecimento ôhmico. (Tese de doutorado). Universidade Federal do Rio Grande do Sul.

[14] NEVES, M. V. M. (2009). Polpa de acerola (Malpighia emarginata D.C.) adicionada de extrato comercial de própolis: avaliação físico-química e sensorial. (Dissertação de mestrado) Universidade Federal Rural de Pernambuco, Recife. 


\section{Capítulo 7}

\section{Extrato hidroalcoólico de própolis: Avaliação de fitoquímicos $e$ da atividade antioxidante $e$ antibacteriana}

\section{Cristina Jansen Alves}

Tailise Beatriz, Roll Zimmer

Fernanda Doring Krumreich

Eliezer Avila Gandra

Rui Carlos Zambiazi

Resumo: A própolis é produzida pelas abelhas através da coleta de resinas, plantas e flores, sendo parcialmente digeridos e acrescentando-se cera e pólen. Diversos fatores podem interferir na sua composição química, resultando em alterações no conteúdo de fitoquímicos, e, portanto, nas propriedades biológicas. 0 objetivo deste estudo foi avaliar a composição de fitoquímicos em amostras de extratos de própolis do Sul do Brasil, e testar sua capacidade antioxidante e antimicrobiana. Das amostras de própolis foram obtidos extratos hidroalcoólicos, os quais apresentaram alto teor de compostos fenólicos e flavonoides. Foram observadas variações entre as amostras, principalmente quanto à capacidade antioxidante. Todas as amostras apresentaram atividade antibacteriana; porém, os resultados foram superiores na inibição de Staphylococcus aureus e Listeria monocytogenes.

Palavras-chave: compostos fenólicos; extrato hidroalcoólico; antioxidante; bactérias. 


\section{INTRODUÇÃO}

A colmeia é fonte de produtos de alto valor nutritivo e com grandes potencialidades farmacológicas, como o mel, a própolis, o pólen, a cera, a geleia real e a apitoxina. A própolis é um dos produtos apícolas que têm alcançado destaque internacional devido a sua composição química e propriedades biológicas e, apesar disso, ainda é pouco explorada em algumas regiões do Brasil (CASTALDO, CAPASSO, 2002; PEREIRA et al., 2002).

A própolis é um produto elaborado pelas abelhas através de substâncias resinosas e gomosas, que são coletadas de brotos, flores e exsudados de plantas. As abelhas digerem parcialmente estes materiais através da ação das enzimas contidas nas suas secreções salivares, e após acrescentam ainda cera e pólen, formando assim a própolis (SILVA et al., 2012). Sua utilização ocorre desde as civilizações antigas no tratamento de diversas doenças (MARCUCCI et al., 2001; UZEL et al., 2005; TOSI et al., 2007).

Estudos demonstraram que amostras de própolis oriundas de regiões tropicais, especialmente brasileiras, apresentam diferenças na composição química em relação à própolis de outras regiões. 0 Brasil possui clima e vegetação que torna possível às abelhas produzirem uma própolis de alta qualidade; porém, com ampla variação em sua composição química e biológica , , devido a grande biodiversidade de plantas encontradas no Brasil (PEREIRA et al., 2002). Além disso, existem diversos fatores externos que contribuem para as alterações nas características físicas, químicas e sensoriais da própolis, influenciando diretamente nas suas propriedades químicas e biológicas. Os principais agentes causadores desta variação são: as espécies vegetais e sua origem botânica; a localização geográfica; a época do ano; a espécie de abelha (no caso brasileiro também o grau de "africanização" da Apis mellifera); e da forma de coleta e extração do produto (FROZZA et al., 2013).

Devido aos fatores citados, este trabalho visa à caracterização química de amostras de própolis oriundas da região Sul do Rio Grande do Sul, avaliando o conteúdo de seus principais fitoquímicos, de sua capacidade antioxidante e ação antibacteriana.

\section{MATERIAIS E MÉTODOS}

Cinco amostras de própolis produzidas por abelhas Appis mellifera foram coletadas por apicultores na primavera, entre os meses de setembro a novembro de 2013, a partir de quatro cidades (Pelotas, Rio Grande, Canguçu e Pedro Osório) da região Sul do Estado do Rio Grande do Sul do Brasil: Pelotas 1

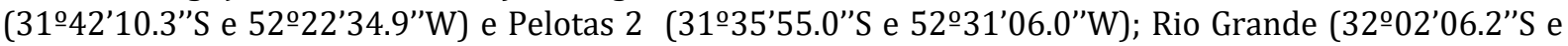

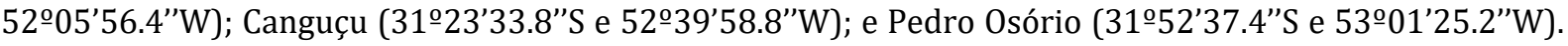
Após a remoção das principais impurezas visíveis, a própolis foi congelada $\left(-20^{\circ} \mathrm{C}\right)$ até o momento das análises. Para cada amostra foram realizadas três repetições das análises.

\subsection{PREPARAÇÃO DOS EXTRATOS HIDROALCOÓLICOS DE PRÓPOLIS (EHP)}

Inicialmente as amostras de própolis bruta foram trituradas com auxílio de nitrogênio líquido. Após preparou-se os extratos de modo semelhante ao realizado por Silva et al. (2012), pesando 10g de própolis e após diluindo com um volume 10 vezes maior de solução de etanol $80 \%$ para obtenção de um extrato a $10 \%(1: 10 \mathrm{~m} / \mathrm{v})$. A extração foi realizada sob agitação em shaker a temperatura ambiente por 3 horas. Após, os extratos foram filtrados em papel filtro para remover as ceras e substâncias menos solúveis. 0 sobrenadante foi removido e mantido sob refrigeração overnight, e posteriormente centrifugado a 150rpm a 5ㄷ por 15 minutos.

\subsection{DETERMINAÇÃO DO TEOR DE COMPOSTOS FENÓLICOS}

Para a determinação do total de compostos fenólicos foi utilizado o método de Folin-Ciocalteu (ALVES, KUBOTA, 2013), utilizando reagente de Folin-Ciocalteu 0,2 N, e solução de carbonato de sódio (7,5\%). A absorbância foi medida a $725 \mathrm{~nm}$ em espectrofotômetro (JENWAY $6705 \mathrm{UV} / \mathrm{Vis}$ ). 0 ácido gálico, nas concentrações de 30 a $500 \mu \mathrm{g} . \mathrm{mL}-1$, foi utilizado para construir a curva de calibração. 


\subsection{DETERMINAÇÃO DO TEOR DE FLAVONOIDES}

O método colorimétrico utilizando cloreto de alumínio ( $\mathrm{AlCl} 3$ ) foi utilizado para a determinação do teor de flavonoides, conforme metodologia descrita por Mello, Petrus e Hubinger (2010). Para a curva de calibração foram utilizados soluções de quercetina em etanol (80\%), com concentrações variando de 10 a

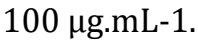

\subsection{ENSAIO DE SEQUESTRO DE RADICAIS DDPH}

A atividade antioxidante pelo método de sequestro de radicais livres DPPH dos extratos foi realizada segundo o método descrito por Vicentino e Menezes (2007), com poucas alterações. 0 efeito bloqueador do DPPH foi calculado pela porcentagem de descoloração do DPPH usando a equação 1:

$$
\%=[(\text { Abs branco }- \text { Abs extrato }) / \text { Abs branco }] \times 100 \quad \text { (eq.1) }
$$

\subsection{ATIVIDADE ANTIBACTERIANA}

A atividade antibacteriana foi realizada pela técnica de microdiluição em caldo, por meio da determinação da Concentração Inibitória Mínima (CIM) e Concentração Bactericida Mínima (CBM), de acordo com a metodologia descrita por Cabral et al. (2009) com pequenas modificações. Foram utilizadas cepas padrão de Staphylococcus aureus ATCC 2913, Escherichia coli 0157:H7 ATCC 43895 e Listeria monocytogenes ATCC 7644

A técnica foi desenvolvida em microplacas de 96 poços, nos quais foram adicionados $100 \mu \mathrm{L}$ de caldo BHI previamente inoculado. Em seguida, foram adicionados $100 \mu \mathrm{L}$ do extrato hidroalcoólico de própolis (EHP) em concentrações que variaram de 0,1-12 mg/mL (diluição seriada de razão 2). Como controle foi utilizado o etanol $80 \%(\mathrm{v} / \mathrm{v})$, solvente utilizado para solubilizar o EHP. As microplacas foram incubadas a $37^{\circ} \mathrm{C}$ por $24 \mathrm{~h}$. Após a incubação, foram adicionados $30 \mu \mathrm{L}$ do corante Resazurina $(0,01 \%$; $\mathrm{m} / \mathrm{v})$ para verificar os poços em que houve crescimento bacteriano. Após $3 \mathrm{~h}$ de incubação, nos poços em que não houve mudança na cor do corante, ou seja, permaneceu roxo, foi considerada a ausência de bactérias viáveis. Qualquer evidência na mudança da coloração se considerou crescimento bacteriano. Para a determinação da CBM, alíquotas de $10 \mu \mathrm{L}$ do meio de cultura dos poços considerados com efeito inibitório foram semeadas em placas de Petri contendo ágar BHI e incubados a $37^{\circ} \mathrm{C}$ por $24 \mathrm{~h}$. A CBM foi considerada como a menor concentração na qual não houve crescimento de colônias na superfície do meio de cultura.

\subsection{ANÁLISE ESTATÍSTICA}

Os resultados foram expressos em médias referentes às determinações realizadas em triplicata e posteriormente submetidos à análise de variância (ANOVA). Para comparação das médias foi utilizado o teste de Tukey e Dunnet $(\mathrm{p}<0,05)$.

\section{RESULTADOS E DISCUSSÃO}

\subsection{CONTEÚDO DE FITOQUÍMICOS}

O teor de compostos fenólicos variou de 56,92 a 200,39 mg EAG.g-1 (Tabela 1). As amostras oriundas de Rio Grande e de Pelotas 2 apresentaram valores superiores as demais, diferindo significativamente, apresentando teores três vezes superiores aos encontrado para as amostras de Pedro Osório e Canguçu. As amostras de própolis oriundas de Pelotas diferiram entre si, demonstrando que existe variação na composição química da própolis mesmo em amostras coletadas na mesma cidade.

Houve grande variação para o teor total de flavonoides, de 10,04 a 112,48 mg EQ.g-1. Assim como para a análise de compostos fenólicos, a amostra oriunda de Rio Grande foi a que apresentou maior quantidade. Moreira et al. (2008) analisaram o teor total de compostos fenólicos nos extratos de própolis de Portugal, encontrando diferenças de acordo com a região de procedência, de 151,00 mg EAG.g-1 a 329,00 mg EAG.g1. 
De fato, os dados encontrados sugerem que a própolis de diferentes localidades apresentam variações no conteúdo de compostos fenólicos. Segundo Falcão et al. (2010), a diversidade de compostos fenólicos presentes na própolis está relacionada com a complexidade das resinas vegetais utilizadas pelas abelhas, mas também pela combinação de várias espécies botânicas visitadas, principalmente em locais de grande diversidade de plantas. De acordo com Silva et al. (2012), o uso de solventes muito polares como a água, reduz sua solubilidade, pois a própolis possui compostos hidrofílicos e hidrofóbicos, sendo mais apropriado o uso de solventes de polaridade intermediária, como o álcool etílico. Além disso, extratos hidroalcoólicos apresentam a vantagem de não serem tóxicos ao consumo humano.

Tabela 1. Teor total de compostos fenólicos, flavonoides e capacidade antioxidante através do 2,2-difenil1-picril-hidrazil (DPPH) de extratos de própolis de diferentes cidades do Sul do Brasil.

\begin{tabular}{|c|c|c|c|}
\hline Amostras & $\begin{array}{c}\text { Compostos fenólicos } \\
\text { mg EAG.g-1 }\end{array}$ & $\begin{array}{l}\text { Flavonoides } \\
\text { mg EQ.g-1 }\end{array}$ & $\begin{array}{c}\text { DPPH } \\
\text { IC50 (mg.g-1) }\end{array}$ \\
\hline Quercetina & - & - & 74,11 \\
\hline Canguçu & $56,92 \mathrm{c}$ & $10,04 \mathrm{e}$ & _ $* *$ \\
\hline P. Osório & $60,08 \mathrm{c}$ & $16,70 \mathrm{~d}$ & $* *$ \\
\hline Pelotas & $122,52 \mathrm{~b}$ & $60,40 \mathrm{c}$ & $90,23 \mathrm{a}$ \\
\hline Pelotas 2 & $189,81 \mathrm{a}$ & $102,87 \mathrm{~b}$ & $108,69 \mathrm{a}$ \\
\hline Rio Grande & $200,39 a$ & $112,48 \mathrm{a}$ & $50,35 \mathrm{a}$ \\
\hline
\end{tabular}

Médias seguidas pela mesma letra na coluna não diferem entre si pelo teste de Tukey $(\mathrm{p} \leq 0,05)$. *Diferem na coluna do controle quercetina, pelo teste de Dunnet $(\mathrm{p} \leq 0,05)$._ $^{* *}$ Amostra não tingiu o IC50 nas concentrações testadas.

\subsection{CAPACIDADE ANTIOXIDANTE PELO SEQUESTRO DO RADICAL DPPH}

Avaliando as diferentes concentrações de extratos, observou-se que da menor até a maior concentração empregada, a amostra oriunda de Rio Grande apresentou capacidade antioxidante próxima ao valor do padrão quercetina utilizada como controle (dados não mostrados). Porém, as amostras da cidade de Canguçu e de Pedro Osório, mesmo em concentrações maiores, não foram eficientes para inibir 50\% dos radicais livres (IC50), não sendo possível encontrar o valor de IC50 para essas amostras (Tabela 1), sendo necessárias concentrações de extrato de própolis superiores das empregadas no presente estudo.

As amostras que apresentaram maior capacidade antioxidante (Rio Grande e Pelotas) também apresentaram altos teores de compostos fenólicos e de flavonoides, sugerindo uma grande influência desses compostos na ação contra os radicais livres. Campos et al. (2014) analisando EHP provindas do Estado de Mato Grosso-Brasil, pelo método de DPPH, encontraram IC50 de $40 \mu \mathrm{g}$.mL-1, demostrando que esta própolis apresenta capacidade antioxidante superior as amostras analisadas neste trabalho.

\subsection{ATIVIDADE ANTIBACTERIANA}

Todas as amostras de própolis testadas apresentaram atividade antibacteriana (Tabela 2), porém os resultados variaram de acordo com concentração e com a cidade de origem da própolis.

Tabela 2. Concentração inibitória mínima (CIM) e concentração bactericida mínima (CBM) de extratos hidroalcoólicos de própolis de cidades do Sul do Brasil frente a bactérias patogênicas Staphylococcus aureus, Escherichia coli 0157:H7 e Listeria monocytogenes.

\begin{tabular}{|c|c|c|c|c|c|c|}
\hline \multirow{2}{*}{ Amostras } & \multicolumn{2}{c}{ S. aureus } & CIM & CBM & \multicolumn{2}{c}{ CIM coli } \\
\cline { 2 - 7 } & CIM & CBM & 3,13 & 0,36 & 3,13 & 6,25 \\
\hline Canguçu & 0,53 & 6,25 & 0,65 & 6,25 & 6,26 & 12,50 \\
\hline P. Osório & 0,20 & 1,25 & 1,33 & 1,56 & 1,56 & 1,56 \\
\hline Pelotas & 0,10 & 1,25 & 1,04 & 1,56 & 1,31 & 1,56 \\
\hline Pelotas 2 & 0,43 & 1,56 & 0,91 & 1,56 & 3,13 & 3,13 \\
\hline Rio Grande & 0,20 & &
\end{tabular}


Para a E. coli, as duas amostras de própolis de Pelotas foram as que apresentaram maior potencial inibitório, pois provocaram inibições bacterianas em menores concentrações de extrato, apresentando o menor CIM (1,31 e 1,56 mg.mL-1). Houve grande variação entre as CIM e as CBM.Para a S. aureus e L. monocytogenes a CBM de algumas bactérias necessitou da concentração de própolis seis vezes superior a CIM, Já para E. coli o dobro da concentração de CIM foi suficiente para a CBM. De acordo com Tosi et al. (2007), os efeitos bactericidas e bacteriostáticos de extratos de própolis dependem da concentração adicionada e do método de extração.

Como esperado, a E. coli apresentou maior resistência ao extrato de própolis. Autores relataram que alguns trabalhos encontraram ação somente em bactérias Gram-positivas e alguns fungos, e outros encontraram atividade também contra as bactérias Gram-negativas, porém utilizando maior concentração do extrato de própolis, segundo o que ocorreu no presente estudo (MARCUCCI, 1995; TOSI, et al., 2007; SILVA et al., 2012).

Acredita-se que os compostos presentes na própolis, como flavonoides, ácidos e ésteres aromáticos atuem na parede celular destas bactérias, e como as Gram-negativas possuem estrutura quimicamente mais complexa, apresentando a membrana externa contendo proteínas, fosfolipídios e lipopolissacarídeos, estas estruturas reduzem a efetividade desses compostos. Os lipopolissacarídeos promovem uma barreira à permeabilidade de substâncias hidrofóbicas, e são os responsáveis pela antigenicidade, toxicidade e patogenicidade das bactérias Gram - negativas, o que as tornam mais resistentes à ação da própolis do que as bactérias Gram - positivas (KALOGEROPOULOS et al., 2009; SILVA et al., 2012).

Castro et al. (2007) também encontraram variações nos valores de CIM de acordo com os períodos de sazonalidade envolvendo as safras apícolas em amostras de própolis da região Sudeste e Nordeste do Brasil. No período de inverno houve diminuição da atividade antimicrobiana e aumento em períodos de seca, isto porque no inverno há uma menor concentração dos fitoquímicos no vegetal onde as abelhas coletam a resina.

As amostras de Pelotas e Rio Grande apresentam os melhores resultados para a atividade antibacteriana, havendo uma associação entre a concentração de fitoquímicos e atividade antimicrobiana. Observou-se que as amostras com maior capacidade antioxidante apresentaram também as melhores atividades bactericidas.

\section{CONCLUSÃO}

Pode-se verificar grande variação de compostos fenólicos e flavonoides para as amostras analisadas, o que influenciou na atividade antioxidante, sendo que amostras com maior teor de fitoquÍmicos foram melhores na ação antioxidante pelo método DPPH. Quanto à atividade antibacteriana, todos os extratos das amostras de própolis foram eficazes na inibição das bactérias testadas, apresentando resultados promissores na inibição das bactérias S. aureus e L. monocytogenes.

\section{REFERÊNCIAS}

[1] ALVES, E. KUBOTA, E. H. (2013). Conteúdo de fenólicos, flavonoides totais e atividade antioxidante de amostras de própolis comerciais. Revista de Ciências Farmacêuticas Básica e Aplicada, 34 (1), 37-41.

[2] CABRAL I. S. R. OLDONI T. L. C. PRADO A. BEZERRA R. M. N. ALENCAR S. M. IKEGAKI M. ROSALEN P. (2009). Composição fenólica, atividade antibacteriana e antioxidante da própolis vermelha brasileira. Química Nova, 32 (6), 1523-27.

[3] CAMPOS, J. F.dOS SANTOS, U. P. MACORINI, L. F. B. DE MELO, A. M. M. F. BALESTIERI, B. P. PAREDESGAMERO, E. J. CARDOSO, C. A. L. SOUZA, K. P.; DOS SANTOS, E. L. (2014). Antimicrobial, antioxidant and cytotoxic activities of própolis from Melipona orbignyi (Hymenoptera, Apidae). Food and Chemical Toxicology, 65, 374-380.

[4] CASTALDO C. CAPASSO, F. (2002). Propolis, an old remedy used in modern medicine. Fitoterapia, 73 (1), S1-

S6.

[5] CASTRO, M. L. CURY, J. A. ROSALEN, P. L. ALENCAR, S. M. IKEGAKI, M. KOO, H. DUARTE, S. (2007). Própolis do sudeste e nordeste do Brasil: influência da sazonalidade na atividade antibacteriana e composição fenólica. Quimica Nova, 30 (7),1512-1516. 
[6] FALCÃO, S. VILAS- BOAS, M. ESTEVINHO, L.M. BARROS, C. DOMINGUES, M.R.M. CARDOSO, S.M. (2010). Phenolic characterization of Northeast Portuguese Propolis: usual and unusual compounds. Analytical and Bioanalytical Chemistry, 396, 887-897.

[7] FROZZA, C. O. da S. GARCIA, C. S. C. GAMBATO, G. SOUZA, M. D. O. de; SALVADOR, M. MOURA, S. PADILHA, F. F. SEIXAS, F. K. COllares, T. BORSUK, S. DEllagostin, O. A. PÊGAS, J. A. ROESCH-ElY, M. (2013). Chemical characterization, antioxidant and cytotoxic activities of Brazilian red propolis. Food and Chemical Toxicology, 52, 137142.

[8] KAlogeropouloS, N. KONTElES, S. J. TROUllidou, E. MOURTZINOS, I. KARATHANOS, V. T. (2009). Chemical composition, antioxidant activity and antimicrobial properties of propolis extracts from Greece and Cyprus. Food Chemistry, 116, 452-461.

[9] MARCUCCI, M. C. FERrERES, F. GARCÍA-ViguerA, C. BANKOVA, V. S. DE CASTRO, S. L. DANTAS, A. P. VALENTE, P. H. M. PAULINO, N. (2001). Phenolic compounds from Brazilian propolis with pharmacological activities. Journal of Ethnopharmacology, 74, 105-112.

[10] MARCUCCI, M.C. (1995). Propolis: chemical composition,biological properties and therapeutic activity. Apidologie, 26, 83-99.

[11] MELLO, B. C. B. S. PETRUS, J. C. C. HUBINGER, M. D. (2010). Concentration of flavonoids and phenolic compounds in aqueous and ethanolic propolis extracts through nanofiltration. Journal of Food Engineering, 96, 533539.

[12] MOREIRA, L. DIAS, L. G. PEREIRA, J. A. ESTEVINHO, L. (2008). Antioxidant properties, total phenols and pollen analysis of propolis samples from Portugal. Food and Chemical Toxicology, 46, 3482 - 3485.

[13] PEREIRA, A. dos S. SEIXAS, F. R. M. S.; NETO, F. R. de A. (2002). Própolis: 100 anos de pesquisa e suas perspectivas futuras. Química Nova, 25 (2), 321-326.

[14] SILVA, J. C.; RODRIGUES, S.; FEÁS, X.; ESTEVINHO, L. M. (2012). Antimicrobial activity, phenolic profile and role in the inflammation of própolis. Food and Chemical Toxicology, 50, 1790-1795.

[15] TOSI, E. A. RÉ, E. ORTEGA, M. E. CAZZOLI, A. F. (2007). Food preservative based on propolis: Bacteriostatic activity of propolis polyphenols and flavonoids upon Escherichia coli. Food Chemistry, 104, 3, 1025-1029.

[16] UZEL, A. SORKUN, K. ÖNÇAG, Ö. ÇOGULU, D. GENÇAY, Ö.; SALIH, B. (2005). Chemical compositions and antimicrobial activities of four different Anatolian propolis samples. Microbiological Research, 160, 189-195.

[17] VICENTINO, A. R. R. MENEZES, F. S. (2007). Atividade antioxidante de tinturas vegetais, vendidas em farmácias com manipulação e indicadas para diversos tipos de doenças pela metodologia do DPPH. Revista Brasileira de Farmacognosia, 17 (3), 384-387. 


\section{Capítulo 8}

\section{Obtenção de hidrolisado proteico a partir de Tilápia do Nilo (Oreochromis niloticus) e aplicação em produtos alimentícios}

\section{Cassandra Meireles Terres Ribeiro \\ André Marcelo Knak \\ Ricardo Pereira Ribeiro}

Resumo: A tilápia do Nilo foi o quarto pescado mais produzido no mundo em 2017, e o volume de resíduos gira em torno de 50\%, e se não tratados adequadamente tornam-se poluentes. 0 objetivo deste trabalho foi obter um hidrolisado proteico por via enzimática, secá-lo em spray-dried, aplicá-lo em produtos alimentícios, verificando a aceitação dos consumidores. Os alimentos adicionados de proteína de peixe foram, barra de cereais, pão de queijo e mistura para bolo sabor chocolate, estes foram submetidos a análise microbiológica, composição química proximal, cor, atividade de água, análise de textura e teste sensorial triangular. A adição de proteína aumentou o teor nutricional dos produtos, bem como deixou as amostras com maior luminosidade, ou seja, mais claras quando comparadas ao controle, já a Aw não variou. A análise de textura mostrou ser necessário aplicar uma força maior nas barras de cereais contendo a proteína de peixe, ao contrário do que ocorreu com o bolo e o pão de queijo. As análises microbiológicas foram satisfatórias todos com crescimento $<101$ UFC/g e ausência para Salmonella. No teste sensorial triangular somente a barra de cereal foi considerada diferente pelos provadores.

Palavras-chave: subprodutos de peixe; hidrólise; proteína; adição em alimentos 


\section{1- INTRODUÇ̃̃o}

A produção de Tilápia do Nilo (Oreochromis niloticus) no Brasil, atingiu 357 mil toneladas produzidas em 2017, um valor $8 \%$ maior que o ano anterior. Essa marca colocou o país em quarto lugar entre os maiores produtores mundiais desse pescado (AYROZA, 2018), sendo a tilápia o quarto pescado mais produzido no mundo em 2017 (FAO, 2018). Em contrapartida de acordo com FAO (2017), enquanto a média per capita mundial de consumo é de $20 \mathrm{Kg} / \mathrm{habitante} / \mathrm{ano}$, no Brasil não ultrapassamos $10 \mathrm{Kg} /$ habitante/ano de pescados.

O volume de resíduos gerados pela indústria pesqueira no geral gira em torno de $50 \%$, sendo o manuseio e destino dos mesmos uma preocupação em todos os países principalmente naqueles em desenvolvimento. Os resíduos quando não tratados corretamente tornam-se poluentes, causando danos ao meio ambiente. Considerando que os resíduos de pescados possuem grande quantidade de nutrientes, sendo elevado teor de proteínas, minerais e lipídios (SILVA; CAMARGO, 2002; SEIBEL; SOARES, 2003), sendo a maioria dos resíduos transformados em farinhas ou óleo, para adição em formulações para nutrição animal (BOSCOLO e FEIDEN, 2007; GONÇALVES, 2011)

Torna-se notável então, a necessidade de desenvolvimento de novas técnicas de processamento, que possibilitem um melhor aproveitamento da matéria prima em sua totalidade, visto que ela contém, quantidade de proteína expressiva e de qualidade, e sua utilização em produtos de baixo valor de mercado, tais como a alimentação animal, farinha de peixe e fertilizante, é um desperdício nutricional (HSU, 2010).

A tilápia possui em média um rendimento de filé de aproximadamente 33\% (BOSCOLO e FEIDEN, 2007), estando os outros $67 \%$ distribuídos em vísceras, cabeça, couro, escamas e carcaça. Da carcaça pode-se obter a carne mecanicamente separada (CMS) que pode ser incorporada diretamente em produtos industrializados tais como salsichas e nuggets por exemplo, ou ainda submetida ao processo de hidrólise. Diante do exposto o objetivo deste trabalho foi obter um hidrolisado proteico por via enzimática aplicá-lo em produtos alimentícios, verificando a aceitação dos consumidores.

\section{2- MATERIAIS E MÉTODOS}

O experimento foi realizado no Serviço Nacional de Aprendizagem Industrial - SENAI Toledo e na Universidade Tecnológica Federal do Paraná - UTFPR câmpus Medianeira. O Projeto foi encaminhado ao Comitê de Ética em Humanos da Universidade Estadual do Oeste do Paraná - Unioeste Cascavel e aprovado (Número do Parecer: 1.255.325/2015).

Os resíduos da filetagem - Carne Mecanicamente separadas (CMS) foram obtidos em frigorífico de tilápias devidamente inscrito no Serviço de Inspeção Federal (SIF), localizado na região Oeste do Paraná. As tilápias com média de idade de 180 dias e peso de $1050 \mathrm{~g}$, previamente insensibilizados eram sangradas, evisceradas e descabeçadas. Após estas etapas os filés eram retirados e as carcaças enviadas para o equipamento de produção da CMS tipo tambor rotativo. Após, a CMS era acondicionada em sacos de polietileno e submetidas ao processo de congelamento a $-18 \mathrm{oC}$.

Todos os reagentes utilizados neste estudo apresentaram grau de pureza analítica.

\subsection{OBTENÇÃO DO HIDROLISADO PROTEICO}

A CMS foi previamente lavada com água destilada a uma temperatura de $45 \mathrm{oC}$ e prensada para retirada do excesso de líquido, este procedimento foi repetido 4 vezes, e visa remoção de sangue residual do processo de abate, bem como o excesso de gordura presente na matéria-prima. 0 hidrolisado foi obtido por via enzimática, utilizando enzima Alcalase ${ }^{\circledR}$ fornecida pela Novozymes $₫$, de acordo com o descrito por Furlan e Oetterer (2002), onde a proporção de CMS e água foi de 1:1, seguida da adição de enzima na proporção de $1 \%$ de matéria-prima adicionada. Visando a aplicação deste hidrolisado em pó em alimentos, a hidrólise foi conduzida sem correção do pH da mistura, com tempo de hidrólise de 120 minutos, inativação da enzima a 90 oC por 10 minutos, seguida de centrifugação a $3000 \mathrm{rpm}$ por 10 minutos (Centrífuga Excelsa II Modelo 206 BL Fanem). O sobrenadante obtido, contendo a proteína hidrolisada, foi submetido a secagem em spray-dryer (Labmaq do Brasil Modelo LM 1.0 ) com temperatura de entrada do ar de 120 oC, taxa de alimentação de $0,5 \mathrm{~L}$ h-1 e vazão do ar de entrada de 3,5m3 min-1; 


\subsection{PESQUISA DE MERCADO}

Para verificar uma possível aceitação/rejeição dos produtos, uma pesquisa de mercado foi realizada, com 150 entrevistados, e pensando em diversificar a aplicação do hidrolisado, propusemos aos entrevistados um produto salgado, o pão de queijo; Um produto doce, o bolo de chocolate (neste caso o produto a ser comercializado seria uma mistura em pó para bolo sabor chocolate); e um produto funcional, a barra proteica.

\subsection{APLICAÇÃO - FORMULAÇÃO DOS PRODUTOS}

$\mathrm{Na}$ tabela 1 encontram-se os ingredientes e suas respectivas porcentagens no produto final.

Tabela 1: formulações dos produtos desenvolvidos

\begin{tabular}{|c|c|c|c|c|c|}
\hline Barra de Cereais & $\%$ & Pão de Queijo & $\%$ & Mistura para bolo & $\%$ \\
\hline Açúcar integral & 21,2 & Polvilho azedo & 16 & Farinha de trigo & 48,46 \\
\hline Xarope de glicose & 12,8 & Polvilho doce & 16 & Açúcar & 22,17 \\
\hline Maltodextrina & 6,3 & Leite & 16 & Chocolate em Pó & 14,68 \\
\hline Água & 2,5 & Queijo parmesão & 15 & Proteína hidrolisada & 9,55 \\
\hline Gordura vegetal & 1,3 & Óleo de soja & 10 & Aroma de Baunilha & 2,94 \\
\hline Glicerina & 1,2 & Ovos & 9 & Fermento químico & 2,2 \\
\hline Proteína hidrolisada & 13 & Proteína hidrolisada & 8 & & \\
\hline Banana desidratada & 11,7 & Queijo parmesão & 7,5 & & \\
\hline Granola & 10,0 & Margarina & 1,5 & & \\
\hline Chia & 10,0 & Sal & 1 & & \\
\hline Centeio & 10,0 & & & & \\
\hline Aroma de avelã & 0,005 & & & & \\
\hline Aroma de baunilha & 0,005 & & & & \\
\hline Total & 100,0 & & 100 & & 100 \\
\hline
\end{tabular}

Para obtenção da barra de cereais, os seis primeiros ingredientes foram misturados e aquecidos sob agitação, até completa dissolução do açúcar para obtenção do xarope de aglutinação. Os demais ingredientes foram misturados, logo após o xarope de aglutinação ainda quente foi adicionado. A mistura foi colocada sobre papel manteiga e em uma superfície lisa, onde ficou até secar. As barras foram então moldadas e embaladas.

Para o desenvolvimento da massa para pão de queijo, os ingredientes líquidos foram adicionados ao liquidificador (Philips Walita RI7636) e batidos, logo após os demais ingredientes foram adicionados e batidos novamente, até a completa homogeneização da massa. A mesma foi acondicionada e estocada sob refrigeração.

Para elaboração da mistura em pó para bolo, todos os ingredientes foram pesados em balança semi analítica (Marca MARTE modelo AS2000C), homogeneizados e acondicionados em embalagens de polietileno. Para fins de comparação, o bolo foi preparado previamente, antes da realização das análises, adicionando-se 3 ovos, $150 \mathrm{~mL}$ de óleo de soja e $150 \mathrm{~mL}$ de leite. 


\subsection{ANÁLISES DE COMPOSIÇÃO PROXIMAL}

Teores de umidade, cinzas e proteína bruta (utilizando 6,25 como fator específico) foram determinados de acordo com procedimento descrito pela Association Official Analytical Chemists (AOAC, 1990) e os lipídios totais extraídos pelo método de Bligh-Dyer (1959).

\subsection{ATIVIDADE DE ÁGUA}

A atividade de água $(\mathrm{Aw})$ foi avaliada a $25 \mathrm{oC}$ em determinador de atividade de água (4TE, Aqualab, Decagon, Pulmann, USA).

\subsection{ANÁLISE DE COR}

Para a medida da cor foi utilizado o colorímetro da Marca Minolta®, Modelo CR 400, com iluminante D65 e ângulo de visão de $10^{\circ}$. As medidas de cor foram realizadas em três diferentes pontos superficiais do hidrolisados obtidos e da matéria-prima, correspondendo à parte central e as laterais das amostras. Os valores de $\mathrm{L}^{*}$ (luminosidade), $\mathrm{a}^{*}$ (componente vermelho-verde) e $\mathrm{b}^{*}$ (componente amarelo-azul) foram expressos conforme o sistema de cor da Commission Internationale de L'Eclairage (CIELAB).

\subsection{ANÁLISE DE TEXTURA}

0 perfil de textura foi obtido por teste de dupla compressão em bolo e pão de queijo, em analisador de textura TA-HD Plus texture analiser (Stable Micro Systems). As condições utilizadas nos testes foram: tipo de teste: Análise do Perfil de Textura (TPA); velocidade de teste: 1,7 mm/s; distância de compressão: $10 \mathrm{~mm}$, equivalente a $50 \%$ de compressão; força de contato: 5,0 g; probe utilizado: cilíndrico de alumínio de $36 \mathrm{~mm}$ de diâmetro (P/36R). Os dados foram coletados no programa "Texture Expert for Windows 1.20" (Stable Micro Systems). Foram analisados os parâmetros firmeza, elasticidade, mastigabilidade, coesividade, adesividade, viscosidade, resiliência e área. Para cada amostra foram realizadas cinco repetições.

$\mathrm{Na}$ barra de cereal, as amostras foram fatiadas com espessura de $1 \mathrm{x} 1 \mathrm{x} 2 \mathrm{~cm}$. Foi realizado o teste de força de cisalhamento com lâmina HDP/BSK, blade set with knife, na velocidade de $5 \mathrm{~mm} / \mathrm{segundo}$ utilizando célula de carga de $100 \mathrm{Kg}$. Os resultados foram expressos em quilograma força (Kgf) da força máxima necessária para o corte das amostras.

\subsection{ANÁLISES MICROBIOLÓGICAS}

A mistura para bolo em pó e a barra de cereais foram avaliadas microbiologicamente quanto à contagem de Bacilus cereus (UFC g-1), pesquisa de Salmonella sp. e contagem de coliformes a $45 \mathrm{oC}$ de acordo com a Resolução (RDC) $n^{\circ}$ 12, de 2 de janeiro de 2001, da Agência Nacional de Vigilância Sanitária (BRASIL, 2001). A mistura para pão de queijo não é um dos produtos contemplados pela RDC 12 (BRASIL, 2001) contudo também foi avaliado microbiologicamente quanto à contagem de Staphylococcus coagulase positiva (UFC g-1), pesquisa de Salmonella sp. e contagem de coliformes a 45 oC.

\subsection{ANÁLISE SENSORIAL - TESTE TRIANGULAR}

Para verificar se a adição de proteína hidrolisada poderia ser feita sem causar alteração no sabor e, portanto, sem que fosse notada pelo provador, foi realizado o teste triangular para saber se os consumidores notariam diferenças estatisticamente significativas entre as formulações. As análises de cada produto foram conduzidas em dias diferentes, e contaram com a participação de 145 julgadores não treinados na análise do bolo de chocolate; 73 julgadores para o pão de queijo e 68 julgadores para a barra de cereais.

\section{3 - RESULTADOS E DISCUSSÃO}

Na busca pela percepção do consumidor acerca da adição de proteína de peixe hidrolisada em produtos alimentícios, foi realizado um levantamento sobre o consumo de tais produtos. Dos 100 entrevistados 
98\% deles consomem pão de queijo, sendo que $63 \%$ costumam consumir semanalmente. Os mesmos $98 \%$ desconhecem a adição de proteína de peixe em alimentos, e $94 \%$ dos entrevistados sinalizaram que experimentariam se tivessem a oportunidade.

Já para os entrevistados sobre barras proteicas, constatou-se que 31\% consomem raramente, e que 20\% dos entrevistados não tem o hábito de consumir. Pensando que este produto é mais conhecido por praticantes de atividades físicas, o questionário contava ainda com a pergunta sobre barra com diferentes cereais acrescida de proteína de peixe hidrolisada, onde $51 \%$ dos entrevistados afirmaram que consumiriam barras de sabores diversos acrescida de proteína e outros $49 \%$ sinalizaram que talvez consumiriam.

Quando questionados sobre a frequência de consumo de bolo de chocolate, $26 \%$ afirmaram consumir frequentemente e $58 \%$ as vezes consomem, apenas 3,3\% não tem o hábito de consumir bolo de chocolate, por possuir intolerância ao glúten e a lactose. Quando perguntados sobre a possibilidade de consumir bolo de chocolate com proteína de peixe, $84 \%$ manifestou-se a favor e outros $16 \%$ não experimentariam.

A partir dos bons resultados oriundos da pesquisa de mercado, testamos formulações corriqueiras dos produtos supramencionados, adicionados de proteína de peixe hidrolisada, bem como da mesma formulação sem adição, a qual chamamos de controle. Todas as análises que seguem, foram realizadas no produto com adição de proteína de peixe hidrolisada e no seu respectivo controle (sem adição de proteína). Bem como, todos os produtos já estavam prontos para o consumo no momento das análises.

A tabela 2 mostra os resultados da composição química proximal dos produtos adicionados de proteína de peixe hidrolisada e seus respectivos controles.

Tabela 2: Composição química proximal de produtos prontos para o consumo adicionados de proteína hidrolisada e seus controles

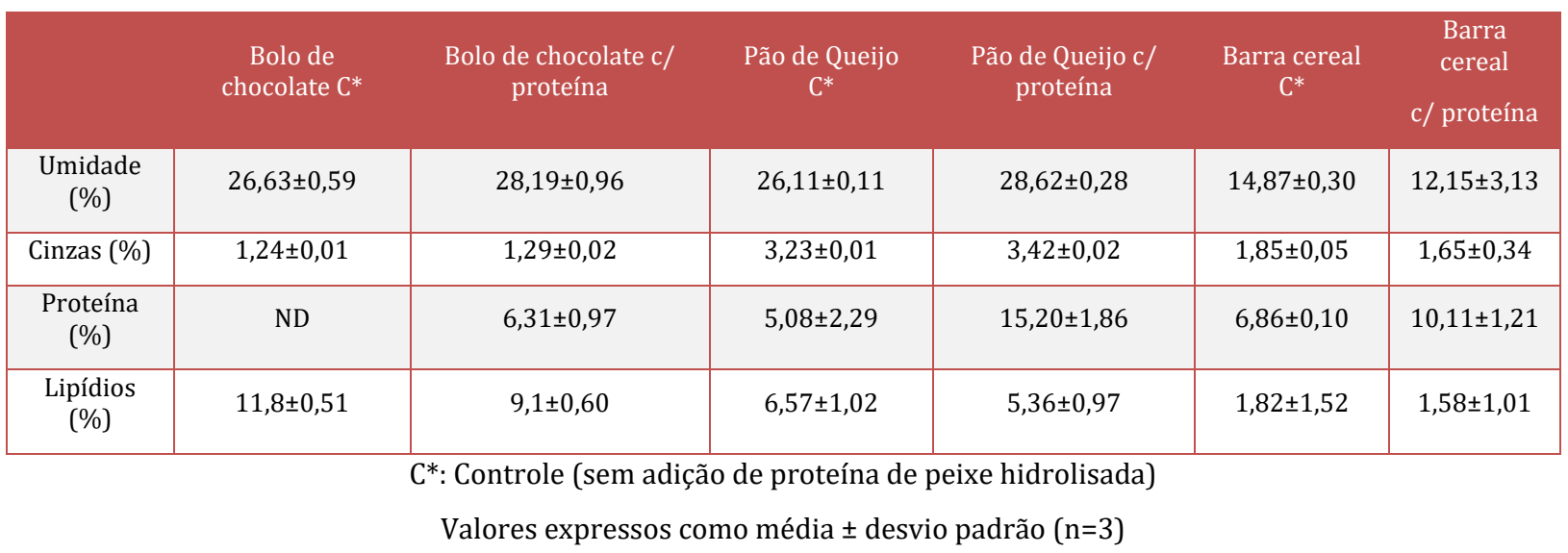

Pode-se verificar que a adição de proteína aos produtos aumentou os teores desse nutriente, o que no caso do bolo de chocolate agregou valor nutricional ao mesmo, pois no bolo controle (tradicional) este nutriente não foi detectado. Para o pão de queijo, o teor de proteína na amostra adicionada, foi quase três vezes maior que a amostra controle. E para barra de cereais o teor proteico da amostra adicionada foi cerca de $32 \%$ maior que a formulação controle. 0 bolo contendo proteína obteve um maior percentual de umidade, possivelmente pela habilidade da proteína em ligar-se com água. 0 mesmo ocorreu com o pão de queijo. Diferente do que foi verificado para barra de cereal, no qual a amostra sem adição de proteína obteve maior teor de umidade. Dos produtos elaborados, o bolo de chocolate foi que o apresentou maior teor de lipídios, o que deve-se ao fato de ter sido adicionado de óleo vegetal para preparo da mistura. Veit et al (2012) ao elaborar e caracterizar bolo de chocolate com adição de $20 \%$ de filé de tilápia encontrou valores inferiores de umidade de $24,5 \%$ e cinzas de $0,68 \%$, e superiores de proteína de 10,98\% e lipídios $12,61 \%$.

Os resultados obtidos para cor e atividade de água dos produtos elaborados estão descritos na tabela X. Como já era esperado devido as características dos produtos e suas matérias-primas, as amostras de pão de queijo mostraram-se mais luminosas $\left(\mathrm{L}^{*}\right)$, tendendo a coloração branca, seguidas da barra de cereais. $\mathrm{E}$ o bolo de chocolate foi o menos luminoso, sendo o bolo controle mais escuro quando comparado ao bolo com proteína. A medida de a* nos mostra que as amostras das barras de cereais tenderam a uma coloração 
mais amarelo-esverdeada, tendo a amostra com proteína uma tendência ao verde por apresentar-se negativa.

Tabela X: Resultados de cor e atividade de água $(\mathrm{Aw})$ de produtos alimentícios adicionados de proteína hidrolisada e seus controles

\begin{tabular}{|c|c|c|c|c|c|c|}
\hline \multicolumn{2}{|r|}{$\begin{array}{l}\text { Bolo c/ } \\
\text { proteína }\end{array}$} & Bolo C* & $\begin{array}{l}\text { Pão queijo c/ } \\
\text { proteína }\end{array}$ & Pão queijo C* & $\begin{array}{l}\text { Barra c/ } \\
\text { proteína }\end{array}$ & Barra C* \\
\hline \multicolumn{7}{|l|}{ Cor } \\
\hline $\mathrm{L}^{*}$ & $27,38 \pm 0,82$ & $\begin{array}{l}25,25 \\
\pm 1,13 \\
\end{array}$ & $71,12 \pm 1,84$ & $71,99 \pm 0,10$ & $\begin{array}{c}61,05 \pm \\
3,47 \\
\end{array}$ & $47,69 \pm 1,65$ \\
\hline$a^{*}$ & $9,75 \pm 0,20$ & $\begin{array}{c}8,68 \pm \\
0,27\end{array}$ & $1,68 \pm 0,84$ & $1,08 \pm 0,40$ & $\begin{array}{c}-0,34 \pm \\
0,51\end{array}$ & $1,02 \pm 0,73$ \\
\hline $\mathrm{b}^{*}$ & $16,65 \pm 2,08$ & $\begin{array}{c}15,04 \pm \\
0,67\end{array}$ & $38,20 \pm 0,10$ & $35,44 \pm 0,84$ & $22,08 \pm 1,5$ & $18,47 \pm 1,00$ \\
\hline $\mathrm{h}^{*}$ & $60,69 \pm 0,43$ & $\begin{array}{c}59,89 \pm \\
0,79 \\
\end{array}$ & $87,48 \pm 1,26$ & $88,25 \pm 0,65$ & $\begin{array}{c}90,53 \pm \\
1,07\end{array}$ & $87,13 \pm 2,18$ \\
\hline$c^{*}$ & $19,93 \pm 0,56$ & $\begin{array}{c}17,40 \pm \\
0,62\end{array}$ & $38,25 \pm 0,10$ & $35,46 \pm 0,84$ & $\begin{array}{c}21,96 \pm \\
1,41\end{array}$ & $18,13 \pm 1,40$ \\
\hline Aw & $0,92 \pm 0$ & $0,93 \pm 0$ & $0,92 \pm 0$ & $0,91 \pm 0$ & $0,64 \pm 0$ & $0,65 \pm 0$ \\
\hline
\end{tabular}
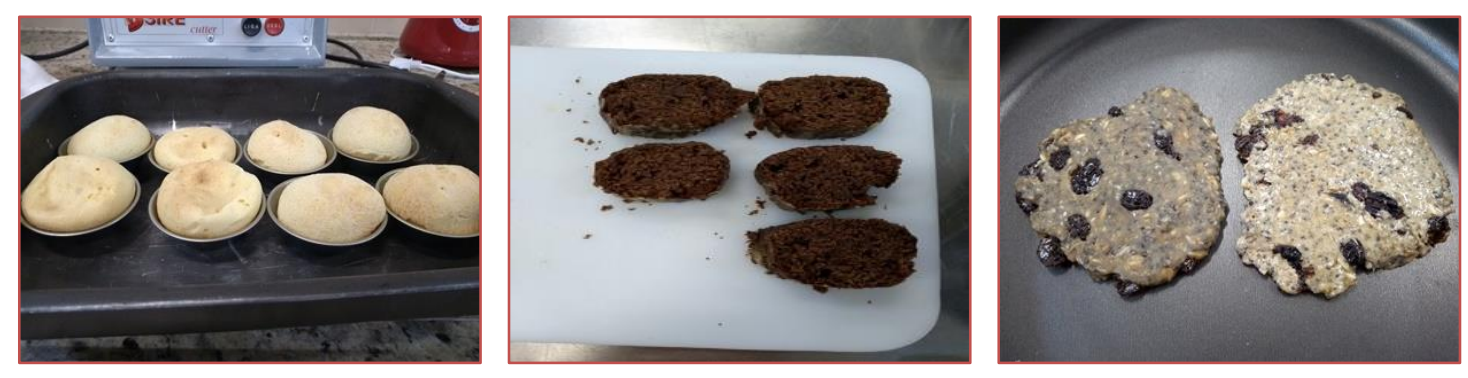

Para a análise de atividade de água (Aw) as amostras de pão de queijo e de bolo de chocolate apresentaram valores próximo, sendo que ambos que foram adicionados de proteína, apresentaram 0,92 de atividade de água. As barras de cereais ambas apresentaram valores baixos de atividade de água, de 0,64 e 0,65 na amostra controle respectivamente. Tais valores devem-se a baixa adição de água nas formulações, e a possível ligação da mesma ao açúcar.

A tabela Y mostra os valores de força (Kgf) necessária para romper as amostras de barra de cereal, nota-se que a amostra com proteína, apresentou-se mais resistente, sendo necessário aplicar uma força maior.

Tabela Y: Resultados de textura, expressos em Kgf, aplicados em barras de cereais com e sem adição de proteína de peixe hidrolisada.

\begin{tabular}{|c|c|c|}
\hline \multirow{2}{*}{$\begin{array}{c}\text { Textura/Força } \\
\text { (Kgf) }\end{array}$} & Barra C* & Barra c/ proteína \\
\hline & 4,703 & 5,380 \\
\hline & 4,525 & 5,761 \\
\hline & 5,104 & 5,490 \\
\hline Média & 4,777 & 5,544 \\
\hline
\end{tabular}


Essa diferença pode estar ligada ao percentual final de umidade e de atividade de água das amostras, pois a água traz aos produtos alimentícios, suculência, o que dá sensação de maciez.

Na tabela Z estão descritos os resultados obtidos na análise de do perfil de textura para bolo de chocolate e pão de queijo. Nota-se que para o atributo firmeza, ambos produtos elaborados com proteína hidrolisada mostraram-se menos resistentes a primeira compressão (mordida), que seus respectivos controles.

A análise de firmeza consiste na força utilizada para a primeira compressão da amostra, simbolizando a primeira mordida no pedaço de bolo. A análise de coesividade está relacionada a primeira e segunda compressão, indicando a primeira e a segunda mordida (CARUSO, 2012), sendo que a análise de resiliência informa a capacidade de voltar ao formato original após ter sofrido deformação elástica, é resultado do impacto do probe a amostra.

\begin{tabular}{|c|c|c|c|c|}
\hline Textura/ Parâmetros & Bolo C* & Bolo c/ proteína & PQ C* & $\begin{array}{c}\text { PQ c/ } \\
\text { proteína }\end{array}$ \\
\hline Firmeza (g) & 1261,42 & 719,98 & 328,23 & 268,81 \\
\hline Adesividade (g) & $-0,518$ & $-0,895$ & $-0,057$ & $-0,234$ \\
\hline Elasticidade & 0,852 & 0,884 & 0,876 & 0,773 \\
\hline Coesividade & 0,460 & 0,504 & 0,644 & 0,650 \\
\hline Viscosidade & 581,73 & 362,79 & 211,15 & 179,61 \\
\hline Mastigabilidade & 492,92 & 321,59 & 185,08 & 142,01 \\
\hline Resiliência & 0,225 & 0,228 & 0,212 & 0,266 \\
\hline Área & $-0,408$ & $-0,895$ & $-0,057$ & $-0,174$ \\
\hline
\end{tabular}

Fonte: Elaborado pelos autores (2017)

Nota-se que, para ambos os produtos, aqueles adicionados de proteína hidrolisada apresentaram-se menos firmes, ou seja, foi necessário aplicar uma força menor para romper as amostras. Este atributo afetou diretamente o atributo mastigabilidade, que refere-se a energia requerida para desintegração do alimento para ser ingerido, sendo que também para ambas amostras controle, foi necessário aplicar uma força maior. 0 atributo elasticidade apresentou pouca diferença entre as amostras, sendo que quando mais próximo a 1, mais elástico é o produto (Pons e Fiszman 1996), para amostra de bolo, a amostra adicionada de proteína apresentou-se mais elástica, e para o pão de queijo, a amostra controle. 0 atributo resiliência apresentou maiores valores, também para as amostras adicionadas de proteína, ou seja, suas capacidades de voltarem aos formatos originais após a primeira compressão também foi melhor. ElBeltagi et al (2017) elaborou massa de pizza com utilização de farinha de grão-de-bico e pó de carpa (Cyprinus carpio) em substituição parcial de farinha de trigo, e verificaram que a firmeza aumentou em todos os níveis de adição de proteína, bem como houve diminuição da elasticidade da massa com $10 \%$ de substituição de farinha de trigo por pó de carpa.

Desai, Brennan e Brennan (2018) fortificou macarrão de sêmola grano duro com pó de bacalhau vermelho (Pseudophycis bachus) com concentrações variando de 5 a 20\% de pó, e verificou que o produto com $20 \%$ apresentou capacidade antioxidante e conteúdo de compostos fenólicos superior a amostra controle (sem adição de pó), além é claro do aumento do teor proteico e de aminoácidos respectivamente, demonstrando que o produtos elaborados são mais nutritivos, equilibrados nutricionalmente e potencialmente funcionais.

Os produtos adicionados de proteína hidrolisada de tilápia foram submetidos as análises microbiológicas, e apresentaram resultados altamente satisfatórios, todos com crescimento $<101$ UFC/g e ausência para Salmonella. Tais resultados indicam boa qualidade e procedência das matérias-primas utilizadas, bem como reflexão das boas práticas de fabricação aplicadas.

A figura 1 apresenta o gráfico dos resultados obtidos no teste triangular, realizado na análise sensorial. Para aplicar este teste é necessário que uma amostra codificada seja escolhida como padrão, e isto seja 
informado ao provador. As outras duas amostras também codificadas são apresentadas e é pedido ao provador que identifique qual destas é igual ao padrão.

Figura 1: Resultados da análise sensorial - teste triangular.

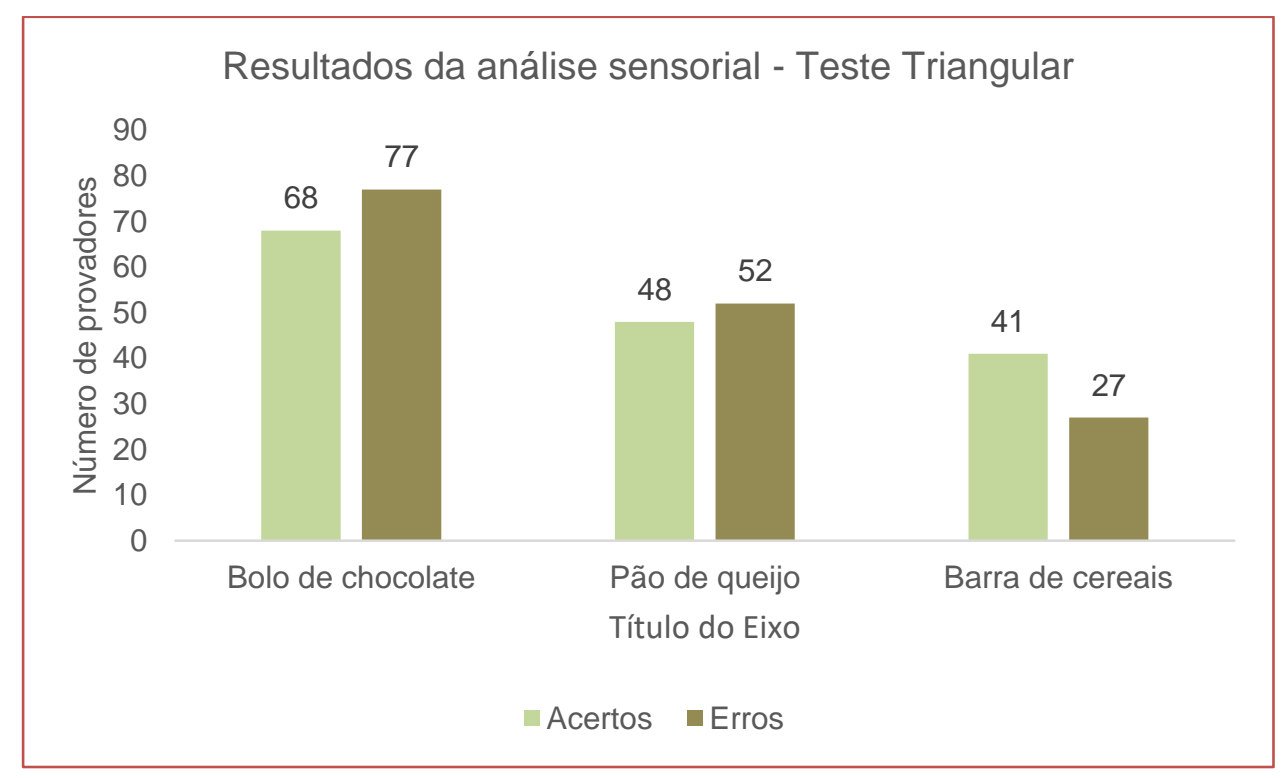

Para os três casos a amostra padrão, era a amostra contendo hidrolisado proteico. Nota-se que tanto para o bolo de chocolate, como para o pão de queijo, os provadores tiveram mais erros do que acertos, o que é um ponto positivo, pois a adição de proteína hidrolisada não afetou as características sensoriais a ponto dos consumidores identificarem a diferença. Já para a barra de cereais, a maioria dos provadores notou diferença e identificou a amostra, e alguns inclusive escreveram nas observações da ficha avaliativa que a amostra padrão e sua respectiva apresentavam um leve gosto amargo, ou seja, as amostras que continham a proteína. Contudo mesmo relatando essa característica de amargor leve, e identificando a amostra correta, nenhum provador correlacionou cheiro ou gosto de peixe nas amostras, o que nos leva a crer que caso adicionássemos um ingrediente mais característico, como chocolate por exemplo, talvez os consumidores não tivessem essa percepção de identificar a amostra igual ao padrão.

Villamil, Váquiro e Solanilla (2017) afirmam que a abordagem e aplicação de hidrolisados proteicos poderiam gerar desenvolvimento no âmbito agrícola, cosmético, farmacêutico, indústria alimentícia e nutracêutica. He, Franco e Zhang (2013) afirmam ainda que as pesquisas devem concentrar-se na transferência dos estudos a nível laboratorial para níveis industriais de aplicação, já que de acordo com KRISTINSSON e RASCO (2000) as pesquisas envolvendo hidrolisados proteicos estão estagnadas a cerca de 20 anos.

\section{4 - CONCLUSÃO}

Como o montante de resíduos gerados pela indústria pesqueira é alto, vê-se uma possibilidade de produção e aplicação de hidrolisado proteico, visto que dos três produtos elaborados, dois deles não tiveram suas características afetadas pela adição de hidrolisado proteico e obtiveram boa aceitação por parte dos consumidores, que foram o bolo de chocolate e o pão de queijo. E para a barra de cereais, fica a sugestão para testes de novas formulações. 


\section{REFERÊNCIAS}

[1] AYROZA, Luiz Marques da Silva. Brasil avança na criação de peixes de água doce. Publicado: 15 de maio de 2018. Acesso em Julho de 2018. < https://canalrural.uol.com.br/noticias/brasil-avanca-criacao-peixes-agua-doce$74468 />$

[2] BOSCOLO, Wilson Rogério; FEIDEN, Aldi. Industrialização de tilápias. Toledo: GFM, 2007. 272 p.

[3] CARUSO, Valeria Remondes. Mistura para o Preparo de Bolo Sem Glúten. Dissertação de mestrado em Engenharia de Processos Químicos e Bioquímicos, 2012. São Caetano do Sul: Universidade Escola de Engenharia Mauá do Centro Universitário do Instituto Mauá, 2012. Disponível em: http://maua.br/files/dissertacoes/mistura-para-opreparo-de-bolo-sem-gluten.pdf

[4] DESAI, A.S. BRENNAN, M.A. BRENNAN, C.S. Effect of Fortification with Fish (Pseudophycis bachus) Powder on Nutritional Quality of Durum Wheat Pasta. Foods, 7, 62; 2018

[5] EL-BELTAGI et al. The impact of using chickpea flour and dried carp fish powder on pizza quality. Plos One 12(9). Setembro de 2017.

[6] FAO. Organização das nações unidas para alimentação e agricultura. El estado mundial de la pesca y la acuicultura 2016. Contribución a la seguridad alimentaria y la nutrición para todos. Roma. 224 pp. Disponível para download em: http://www.fao.org/documents/card/es/c/357c79a0-7fee-428f-a04e-9e86ba1a2ac5/ Acesso em Junho de 2018

[7] FAO. Food and Agriculture Organization of the United Nations. The State of world Fisheries and Aquaculture. Meeting the sustainable Development goals. Roma 2018. 227pp. Disponível para donwload em http://www.fao.org/documents/card/en/c/I9540EN Acesso em Junho de 2018

[8] HE, S. FRANCO, C. ZHANG, W. Functions, applications and production of protein hydrolysates from fish processing co-products (FPCP). Food Research International 50 (2013) 289-297.

[9] HSU, K. (2010). Purification of antioxidative peptides prepared from enzymatic hydrolysates of tuna dark muscle by-product. Food Chemistry, 122, 42-48.

[10] KRISTINSSON, H.G. RASCO, B.A. Fish Protein Hydrolysates: Production, Biochemical, and Functional Properties. Critical Reviews in Food Science and Nutrition, 40:1, 43-81. 2000.

[11] SILVA, G. G. H.; CAMARGO, A. F. M. Valor nutritivo de macrófitas aquáticas flutuantes (Eichhornia crassipes, Pistia stratiotes e Salvinia molesta) utilizadas no tratamento de efluentes de aqüicultura. Acta Scientiarum, v.24, p.519-526, 2002

[12] SEIBEL, N. F.; SOUZA-SOARES, L. A. Produção de Silagem Química com Resíduos de Pescado Marinho. Brazilian Journal Food Technology, v.6, p.333-337, 2003.

[13] VEIT, J. C.; FREITAS, M. B.; REIS, E. S.; MOORE, O. Q.; FINKLER, J. K.; BOSCOLO, W. R.; FEIDEN, A. Desenvolvimento de bolos contendo peixe. Alim. Nutr., Araraquara, v. 23, n. 3, p. 427-433, jul./set. 2012.

[14] VILlAMIL, O. VÁQUIRO, H. SOLANILLA, J.F. Fish viscera protein hydrolysates: Production, potential applications and functional and bioactive properties. Food Chemistry 224 (2017) 160-171 


\section{Capítulo 9}

Efeito do tamanho de partícula nas propriedades reológicas de suspensões aquosas de resíduo agroindustrial em diferentes concentrações de sólidos e temperaturas

Tiago Carregari Polachini

Antonio Mulet

Juan A. Cárcel

Javier Telis Romero

Resumo: A rica composição em amido residual e lignocelulose do bagaço de mandioca, resíduo resultante do processo de extração de amido, tem demonstrado o grande potencial para sua conversão em produtos de maior valor agregado como fibras alimentares, açúcares fermentescíveis e bioetanol. Para isso, os produtos e processos envolvidos necessitam ser corretamente caracterizados. Sendo assim, a reologia de diferentes suspensões aquosas de bagaço de mandioca foi estudada a fim de proporcionar informações necessárias ao projeto das operações unitárias envolvidas. Suspensões com partículas de diferentes diâmetros médio (511,91, 878,43 e 1275,93 $\mu \mathrm{m})$, diferentes concentrações (2-10\%) sob temperaturas entre 1 e $10 \stackrel{\circ}{ } \mathrm{C}$ foram analisadas. 0 modelo de Herschel-Bulkley ajustou-se bem às curvas de escoamento, demonstrando comportamento Newtoniano (n $\approx 1$ e $\tau 0 \approx 0$ ) em suspensões com até $6 \%$ de sólidos. Ligeira pseudoplasticidade com tensão residual observada para maiores concentrações. Partículas maiores de bagaço de mandioca em suspensão resultaram em maior resistência ao escoamento, tendência similarmente observada para a variável concentração de sólidos. Quando as suspensões foram submetidas a maiores temperaturas, o escoamento foi facilitado sem influência significativa no índice de comportamento. Modelos empíricos foram ajustados a tensão residual, índice de consistência, índice de comportamento e viscosidade aparente em função das variáveis significativas $(p<0,05)$ com boa precisão de ajuste.

Palavras-chave: biomassa, amido, lignocelulose; Herschel-Bulkley, modelagem. 


\section{INTRODUÇÃO}

A busca pelo aproveitamento dos resíduos agroindustriais tem impulsionado pesquisas focadas nos processos de conversão destas fontes renováveis em materiais de valor agregado como fibras alimentares, hidrolisados e biocombustíveis. Apesar de sua disponibilidade, baixo custo e propriedades interessantes, estes resíduos lignocelulósicos ainda atuam como gargalo em muitas indústrias de alimentos devido à falta de tecnologia apropriada e informações para seu adequado processamento (Castro \& Pereira-Jr, 2010).

As fecularias são exemplos de indústria de alimentos que geram altas quantidades de resíduos provenientes do processo de extração do amido. As unidades produtoras de amido de mandioca, especificamente, são capazes de gerar aproximadamente 280 toneladas de bagaço úmido $(\sim 85 \%$ de umidade) a partir de 250-300 toneladas de mandioca (Pandey et al., 2000). Estima-se que apenas 25\% do peso da mandioca seja convertido em fécula, implicando em uma produção anual brasileira de mais de 2 milhões de toneladas de bagaço de mandioca úmido (Fiorda, Soares-Jr, Silva, Souto, \& Grossmann, 2013).

0 bagaço de mandioca, ou também chamado de farelo de mandioca, é um material fibroso de baixo teor proteico que apresenta em sua composição aproximadamente $50 \%$ (b.s.) de amido residual proveniente do processamento do tubérculo (Pandey et al., 2000). A alta disponibilidade de macromoléculas vegetais como amido, celulose e hemicelulose torna o bagaço um substrato viável para obtenção de produtos de maior valor agregado (Pasquini, Teixeira, Curvelo, Belgacem, \& Dufresne, 2010). A hidrólise destas macromoléculas promove a liberação de açúcares redutores ou carboidratos que podem ser facilmente fermentados por microrganismos, originando produtos como ácido lático e bioetanol (John, Nampoothiri, \& Pandey, 2006; Woiciechowski, Nitsche, Pandey, \& Soccol, 2002).

Entre os fatores determinantes para o controle do processo, encontra-se o estudo das propriedades físicas do material a ser estudado. A determinação do comportamento e parâmetros reológicos são fatores essenciais no projeto de processos eficientes ligados às operações unitárias de bombeamento, agitação e mistura da biomassa em meio aquoso (Riedlberger \& Weuster-Botz, 2012). Ressalta-se, porém, que o comportamento reológico destas suspensões é altamente dependente de uma série de fatores como: composição química, tamanho e forma de partículas, temperatura, concentração, efeitos de superfície, presença de aditivos, etc (Stickel et al., 2009).

Sendo assim, este trabalho buscou determinar e avaliar o comportamento reológico em regime de escoamento estacionário de suspensões aquosas contendo bagaço de mandioca em pó de diferentes tamanhos médios de partícula em condições variadas de temperatura e concentração de sólidos.

\section{MATERIAL E MÉTODOS}

\subsection{MATERIAIS}

O bagaço de mandioca úmido foi obtido em uma fecularia da região noroeste do estado de São Paulo, para posterior secagem em secador convectivo de bandejas sob uma temperatura de 50 o $\mathrm{C}$ por aproximadamente 24 horas. 0 resíduo seco foi triturado em moinho de facas M4FH1C (PHD, Piracicaba, Brasil) a uma velocidade de $1750 \mathrm{rpm}$ com três diferentes malhas de peneiras com diâmetro de abertura de $1,7,0,85$ e $0,5 \mathrm{~mm}$.

As suspensões foram preparadas em diferentes concentrações de biomassa ( 2 a $10 \% \mathrm{~m} / \mathrm{m}$ ) em água destilada, usando uma balança analítica. Estas suspensões foram compostas de partículas de três diâmetros médios: 511,91, 878,43 e 1275,93 m. Os tamanho foram previamente determinados pela distribuição de tamanho de partículas em peneiras da série Tyler e subsequente ajuste do modelo teórico de Rosin-Rammler-Bennet (Allen, 1981) aos dados de retenção mássica em cada peneira.

\subsection{ANÁLISES REOLÓGICAS}

As análises reológicas foram realizadas em triplicata em um reômetro rotacional AR-G2 (TA Instruments, EUA) com tensão controlada. Para isso, utilizou-se a geometria SPC (Starch Pasting Cell) com gap de 5500 $\mu \mathrm{m}$ a qual promove constante movimento da suspensão a fim de evitar a sedimentação das partículas e escorregamento na parede.

Aproximadamente $28 \mathrm{~cm}^{3}$ de cada suspensão foram inseridos no sistema, mantendo-o à temperatura constante de $1,10,20,30,40,50$ e $60{ }^{\circ} \mathrm{C}$ pela circulação de água do próprio banho do equipamento. 0 s 
ensaios foram realizados variando a taxa de deformação de 0,1 a $260,5 \mathrm{~s}-1$, onde foram obtidas as médias das tensões de cisalhamento como resposta a cada taxa de deformação estabelecida.

\subsection{MODELAGEM MATEMÁTICA E ANÁLISE ESTATÍSTICA}

Diferentes modelos teóricos comumente conhecidos foram ajustados aos reogramas obtidos para cada ensaio. Os modelos de Newton, Ostwald-de Waele (ou Lei da Potência), Bingham e Herschel-Bulkley, representados pelas Equações (1), (2), (3) e (4), respectivamente, foram ajustados utilizando o programa OriginPro 8.0 (OriginLab Corporation Ltd., Northampton, EUA):

$$
\begin{aligned}
& \tau=\mu \dot{\gamma} \\
& \tau=k \dot{\gamma}^{n} \\
& \tau=\tau_{0}+\eta_{B} \dot{\gamma} \\
& \tau=\tau_{0}+k \dot{\gamma}^{n}
\end{aligned}
$$

Nas equações citadas, $\tau$ representa a tensão de cisalhamento (Pa), $\dot{\gamma}$ a taxa de deformação (s-1), $\mu$ a viscosidade newtoniana (Pa·s), $\mathrm{k}$ o índice de consistência (Pa-sn), $\mathrm{n}$ o índice de comportamento (adimensional), $\tau 0$ a tensão residual (Pa) e $\eta \mathrm{B}$ a viscosidade binghamiana (Pa.s) (Steffe, 1996). A escolha do melhor modelo que se ajusta aos dados experimentais foi feita com base nos valores dos coeficientes de determinação $\left(R^{2}\right)$ e raiz quadrada do erro médio (RQEM).

Os parâmetros do melhor modelo foram correlacionados com a temperatura absoluta (Kelvin), concentração de sólidos (\%) e tamanho médio de partícula $(\mu \mathrm{m})$ através da análise de variância, utilizando o software STATISTICA 10 (StatSoft Inc., Tulsa, EUA) em um intervalo de confiança de 95\%. Com as variáveis significativas (linear, quadrático e interações lineares), foram obtidas regressões para predizer os parâmetros reológicos em distintas condições com boa precisão.

\section{RESULTADOS E DISCUSSÃO}

Os ensaios reológicos foram realizados para as diferentes suspensões nas distintas temperaturas, obtendo-se tensões médias de cisalhamento variando de 0,08 a 427,78 Pa. As tensões de cisalhamento foram maiores para as suspensões mais concentradas, compostas por partículas maiores quando submetidas a temperaturas mais baixas em maiores taxas de deformação. Curvas de escoamento foram plotadas e ajustadas aos modelos teóricos propostos. A Figura 1 apresenta o ajuste do modelo de Herschel-Bulkley $\left(\mathrm{R}^{2}>0,999\right)$ aos dados experimentais para ilustrar a influência do diâmetro médio de partículas, temperatura e concentração de sólidos nas curvas de escoamento.

Figura 1 - Reogramas de suspensões aquosas (a) contendo 6\% de partículas com diâmetro médio de 878,43 $\mu \mathrm{m}$ em diferentes temperaturas; (b) a $60{ }^{\circ} \mathrm{C}$ com partículas de diâmetro médio de 878,43 $\mu \mathrm{m}$ em diferentes concentrações e (c) $6 \%$ concentradas a $60^{\circ} \mathrm{C}$ em diferentes tamanhos médios de partículas.

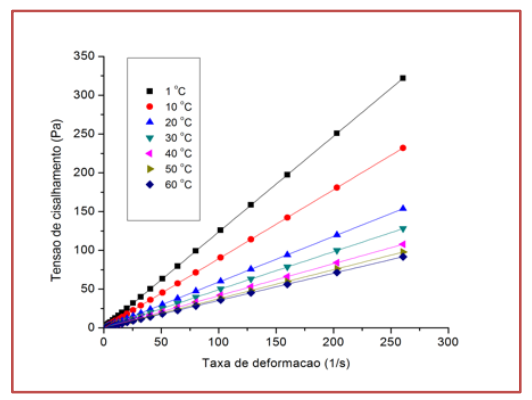

(a)

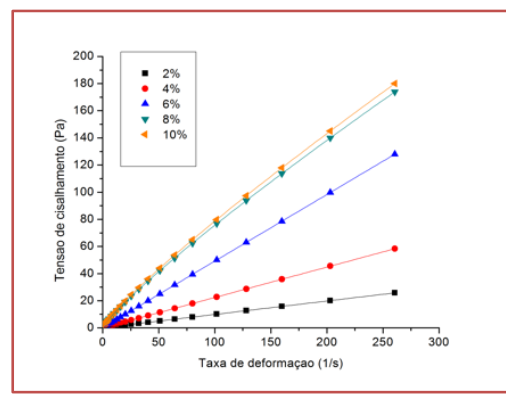

(b)

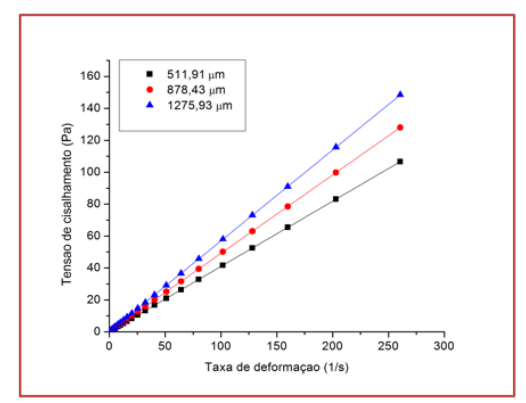

(c)

Fonte: Autores. 
Notou-se que, até aproximadamente $6 \%$ de sólidos, todas as suspensões apresentaram comportamento Newtoniano. Esse comportamento é caracterizado pela dependência linear entre tensão de cisalhamento e taxa de deformação, ausência de tensão residual $(\tau 0 \approx 0)$ e índice de comportamento igual a unidade ( $\mathrm{n} \approx 1)$, que, de fato, está comprovado pelos parâmetros dos ajustes (Tabela 1). Até $6 \%$ de sólidos, as partículas de sólidos provavelmente não interagem entre elas significativamente para induzir a uma variação no comportamento da suspensão ao longo da faixa de taxa de deformação. Isso faz com que o comportamento Newtoniano do meio dispersante (água) prevaleça sobre quaisquer possíveis interações (Polachini et al., 2016).

Quando as suspensões atingem 8\% de sólidos em suspensão, um ligeiro comportamento pseudoplástico é observado com $\mathrm{n}$ atingindo 0,85. Esse comportamento é seguido de um ligeiro aumento na tensão residual. As mesmas tendências puderam ser observadas por Lin et al. (2008) e por Polachini et al. (2016) para diferentes suspensões, incluindo suspensões contendo cascas de amendoim em pó. Embora o mecanismo seja desconhecido, autores sugerem que em suspensões mais concentradas, a quebra de uma rede de estruturas tridimensionais ao longo do aumento da deformação provoca a liberação da água intersticial e a consequente redução da viscosidade aparente (Sato, 1995; Seka \& Verstraete, 2003).

A viscosidade aparente $\left(\eta_{a p p}\right.$ ) a uma taxa de deformação fixa de $10 \mathrm{~s}-1$, comumente utilizada em processos de agitação e mistura (Steffe, 1996), pôde ser calculada após igualar o modelo de Herschel-Bulkley ao modelo de Newton pela equação (5). Os valores variaram de 0,061 a 2,784 Pa·s.

$$
\eta_{a p p}=\frac{\tau_{0}}{\dot{\gamma}}+k \dot{\gamma}^{(n-1)}
$$

Tabela 1 - Parâmetros da equação de Herschel-Bulkley para as suspensões nas diferentes concentrações e diâmetros médios de partícula em temperaturas intermediárias.

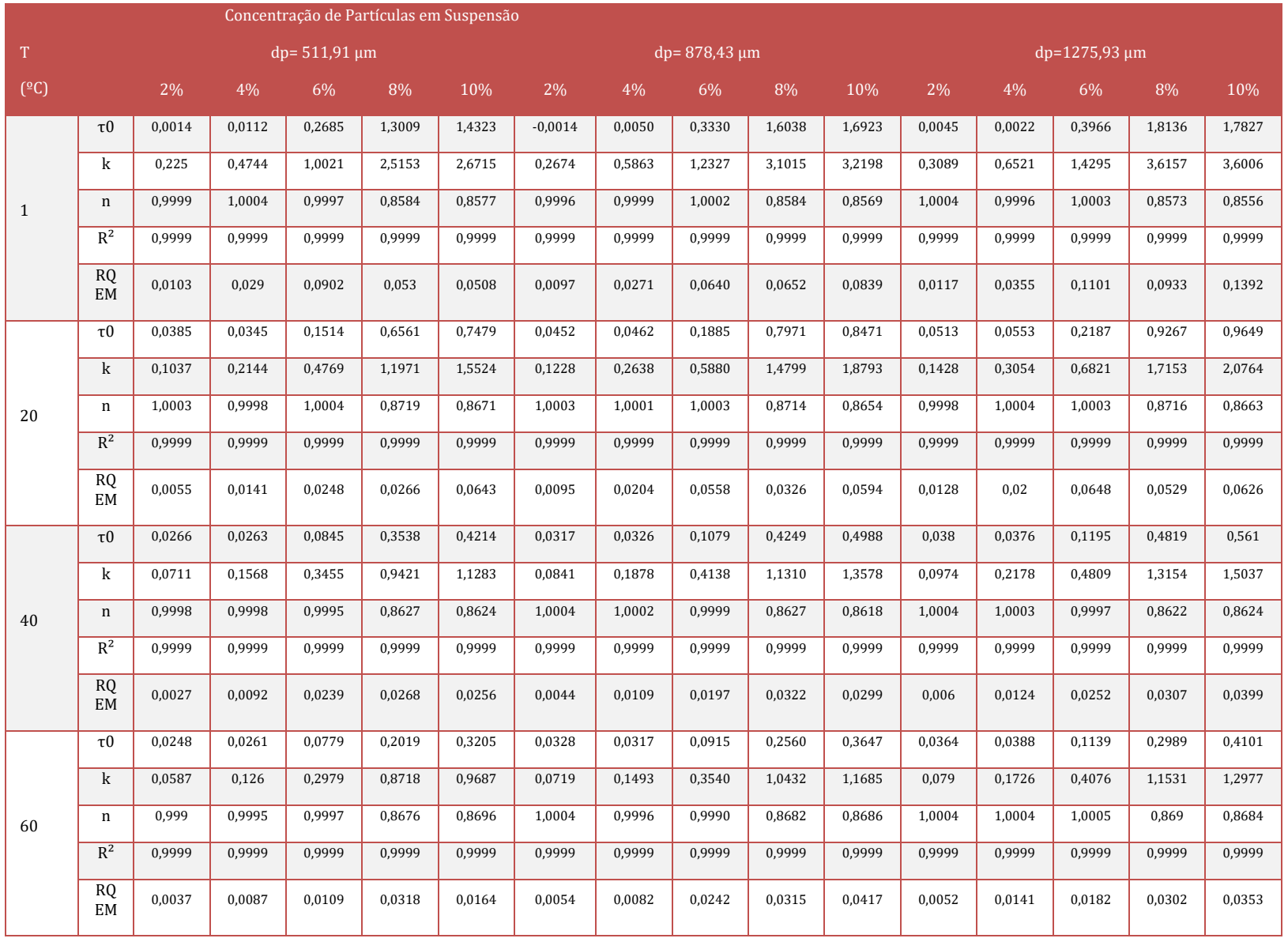

Fonte: Autores. 
Após efetuar uma análise dos efeitos estimados de cada variável sobre os parâmetros reológicos, observou-se que a tensão residual e o índice de consistência são influenciados pela temperatura e concentração de biomassa em nível quadrático, com influencia linear do tamanho de partícula para ambos os casos $(\mathrm{p}<0,05)$.

Conforme mostra a Figura 2, o aumento da concentração de biomassa provocou um acréscimo nos valores da tensão residual, índice de consistência e viscosidade aparente. Esta tendência pode estar relacionada ao maior grau de interação entre as partículas de biomassa em concentrações elevadas de biomassa em suspensão, o que leva a uma maior resistência para iniciar o escoamento (Polachini et al., 2016). Partículas maiores também conferiram maiores forças viscosas às suspensões aquosas. Tal fato pode estar atribuído à presença de fibras mais alongadas, o que confere maior emaranhamento, formação de agregados e interação entre as partículas (Dasari \& Berson, 2007). 0 aumento da temperatura, por sua vez, afeta negativamente os dois parâmetros, provavelmente devido à diminuição entre as forças de interação entre as moléculas na medida em que aumenta o grau de agitação das moléculas causado pela mudança de temperatura. Por outro lado, o índice de comportamento não sofre influência da temperatura e do tamanho de partícula, mas sim com variações na concentração de biomassa.

Figura 2 - (a, b) Tensão residual, (c, d) índice de consistência, (e) índice de comportamento e (f, g) viscosidade aparente em função das variáveis significativas.

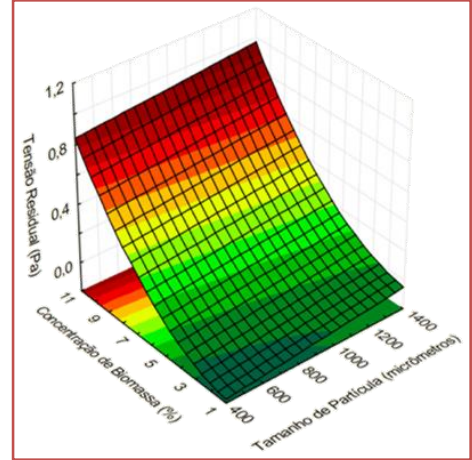

(a)

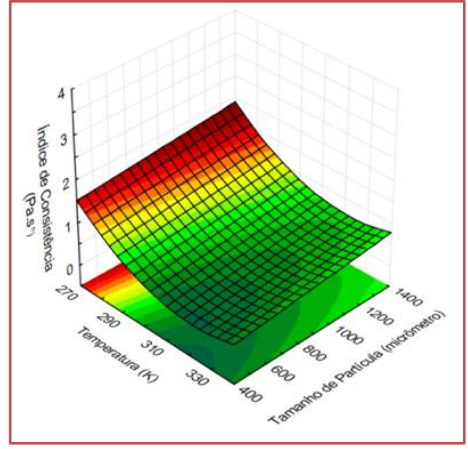

(d)

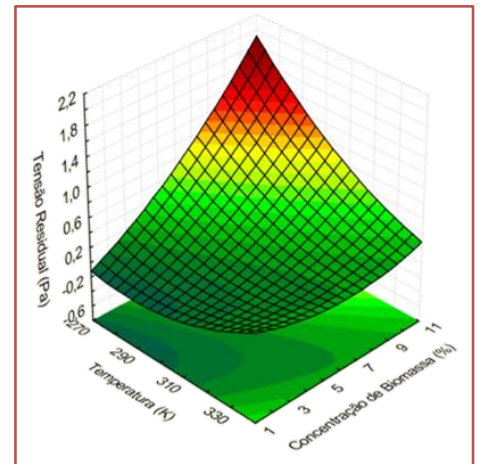

(b)

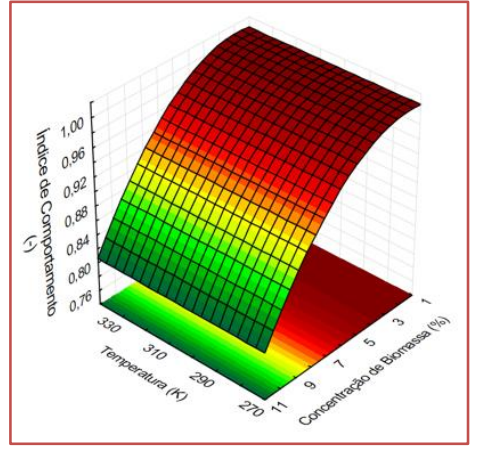

(e)

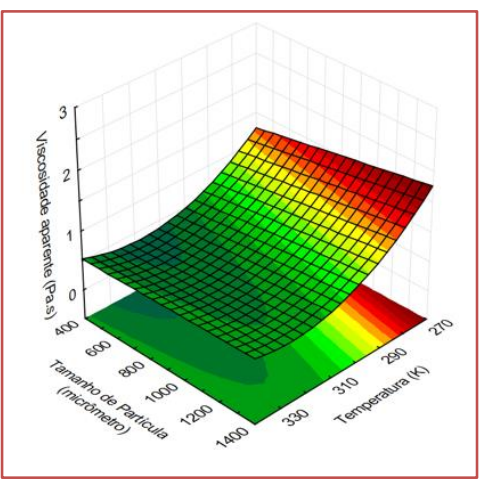

(g)

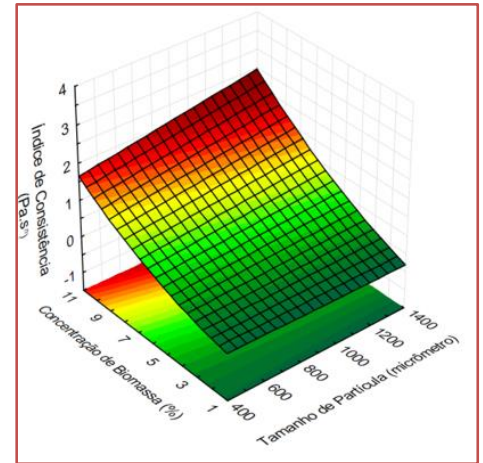

(c)

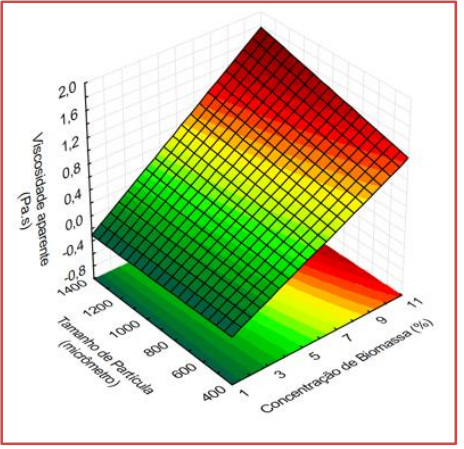

(f)

Fonte: Autores. 
Utilizando os parâmetros significativos para o modelo preditivo de cada parâmetro reológico, foram construídas as equações dispostas na Tabela 2 , com $\mathrm{R}^{2}>0,81$ e $\mathrm{RQEM}<0,26$.

Tabela 2 - Modelos matemáticos ajustados para cada parâmetro reológico.

\begin{tabular}{|l|c|c|}
\hline \multicolumn{1}{|c|}{ Modelos } & $\mathrm{R}^{2}$ & RQEM \\
\hline$\tau_{0}=14,39-0,106 T+0,0002 T^{2}+0,00012 D_{p}+0,923 X+0,0087 X^{2}-0,0031 X T$ & 0,8421 & 0,017 \\
\hline$k=40,22-0,277 T+0,0005 T^{2}+0,00036 D_{p}+1,334 X+0,012 X^{2}-0,0041 X T$ & 0,9030 & 0,026 \\
\hline$n=0,999851+0,008694 X-0,002393 X^{2}$ & 0,8103 & 0,009 \\
\hline$\eta_{\text {app }}=32,04-0,223 T+0,0004 T^{2}+0,00187 D_{p}+$ & 0,9363 & 0,002 \\
$1,05 X 2-0,00001 D_{p} T-0,0031 X T+0,00007 D_{p} X$ & & \\
\hline
\end{tabular}

Fonte: Autores.

\section{CONCLUSÕES}

Neste trabalho, avaliou-se o comportamento reológico de suspensões aquosas de bagaço de mandioca variando o diâmetro médio de partícula, concentração de sólidos e temperatura. 0 ajuste do modelo de Herschel-Bulkley se ajustou às curvas de escoamento com boa precisão $\left(\mathrm{R}^{2}>0,999\right)$. As suspensões menos concentradas em sólidos $(\leq 6 \%)$ apresentaram comportamento Newtoniano, com tensão residual desprezível e índice de comportamento próximo da unidade. 0 aumento do conteúdo de sólidos (>6\%) resultou em um comportamento ligeiramente pseudoplástico com tensão residual considerável e índice de comportamento menor que a unidade. 0 aumento do diâmetro médio das partículas em suspensão, assim como sua concentração, provocou maior resistência da suspensão ao escoamento. Por outro lado, o escoamento das suspensões aquosas contendo bagaço de mandioca foi facilitado mediante aumento da temperatura. Modelos preditivos empíricos puderam ser obtidos para os parâmetros reológicos em função das variáveis significativas, com $\mathrm{R}^{2}>0,81$ e $\mathrm{RQEM}<0,026$.

\section{AGRADECIMENTOS}

Os autores agradecem ao Conselho Nacional de Desenvolvimento Tecnológico e Científico - CNPq (Processo no. 453442/2013-7), à Coordenação de Aperfeiçoamento de Pessoal de Nível Superior - CAPES (Processo no. 88881.132626/2016-01) e à Fundação de Amparo a Pesquisa do Estado de São Paulo FAPESP (Processo no 2017/06518-2) pelo apoio financeiro prestado.

\section{REFERÊNCIAS}

[1] Allen, T. (1981). Particle size measurement. Chapman and Hall: Londres.

[2] Castro, A. M., \& Pereira-Jr, N. (2010). Production, properties and application of cellulases in the hydrolysis of agroindustrial residues. Química Nova, 33(1), 181-188.

[3] Dasari, R. K., Berson, R. E. (2007). The effect of particle size on hydrolysis reaction rates and rheological properties in cellulosic slurries. Appied Biochemistry and Biotechnology. 136-140, 289-299.

[4] Fiorda, F. A., Soares-Jr, M. S. S., Silva, F. A., Souto, L. R. F., \& Grossmann, M. V. E. (2013). Farinha de bagaço de mandioca: aproveitamento de subproduto e comparação com fécula de mandioca. Pesquisa Agropecuária Tropical, 43(4), 408-416.

[5] John, R. P., Nampoothiri, K. M., \& Pandey, A. (2006). Simultaneous saccharification and fermentation of cassava bagasse for l-(+)-lactic acid production using Lactobacilli. Applied Biochemistry and Biotechnology, 134(3), 263-272.

[6] Lin, H.-W., Chang, C.-P., Hwu, W.-H., \& Ger, M.-D. (2008). The rheological behaviors of screen-printing pastes. Journal of Materials Processing Technology, 197(1-3), 284-291.

[7] Pandey, A., Soccol, C. R., Nigam, P., Soccol, V. T., Vandenberghe, L. P. S., \& Mohan, R. (2000). Biotechnological potential of agro-industrial residues. II: cassava bagasse. Bioresource Technology, 74(1), 81-87. 
[8] Pasquini, D., Teixeira, E. M., Curvelo, A. A. S., Belgacem, M. N., \& Dufresne, A. (2010). Extraction of cellulose whiskers from cassava bagasse and their applications as reinforcing agent in natural rubber. Industrial Crops and Products, 32(3), 486-490.

[9] Polachini, T. C., Sato, A. C. K., Cunha, R. L. Telis-Romero, J. (2016). Density and rheology of acid suspensions of peanut waste in different conditions: An engineering basis for bioethanol production, Powder Technology, 294(2016) $168-176$.

[10] Riedlberger, P., \& Weuster-Botz, D. (2012). New miniature stirred-tank bioreactors for parallel study of enzymatic biomass hydrolysis. Bioresource Technology, 106(0), 138-146.

[11] Sato, T. (1995). Rheology of suspensions. Journal of coatings technology, 67, 69-79.

[12] Seka, M. A., \& Verstraete, W. (2003). Test for assessing shear sensitivity of activated sludge flocs: a feasibility study. Water Research, 37(14), 3327-3334.

[13] Steffe, J. F. (1996). Rheological Methods in Food Process Engineering (2 ed.). East Lansing: Freeman Press.

[14] Stickel, J. J., Knutsen, J. S., Liberatore, M. W., Luu, W., Bousfield, D. W., Klingenberg, D. J., et al. (2009). Rheology measurements of a biomass slurry: an inter-laboratory study. Rheologica Acta, 48(9), 1005-1015.

[15] Woiciechowski, A. L., Nitsche, S., Pandey, A., \& Soccol, C. R. (2002). Acid and enzymatic hydrolysis to recover reducing sugars from cassava bagasse: an economic study. Brazilian Archives of Biology and Technology, 45, 393-400. 


\title{
Capítulo 10
}

\section{Avaliação microbiológica de carne bovina moída} comercializada em supermercados do município de Cuiabá - MT

\author{
Letícia Gabriela Pozzer Pires \\ Marina Correa da Costa Abreu \\ Greika Ferreira Moura \\ Soyanne Lima Oliveira de Almeida \\ Cleise de Oliveira Sigarini Sander de Souza \\ Edivaldo Sampaio de Almeida Filho
}

Resumo: A carne bovina é uma excelente fonte de proteínas de elevado valor biológico, fonte de vitaminas do complexo B, ferro, fósforo e potássio. Entretanto, algumas características intrínsecas deste alimento, como elevada atividade de água, $\mathrm{pH}$ próximo a neutralidade, associado ao elevado valor nutricional, fazem deste uma excelente meio para o crescimento de micro-organismos deteriorantes e ou patogênicos. Assim, o presente trabalho buscou avaliar a qualidade higiênico-sanitárias de amostras de carne bovina, previamente moídas, comercializadas em quatro supermercados no Município de Cuiabá - MT, através da determinação de coliformes totais, coliformes termotolerantes e Escherichia coli, mesófilos, pela técnica de Logarítmico (log). Assim, um total de 24 amostras de carne moída foram adquiridas na forma de consumidor, entre os meses de março a junho de 2016 e em seguida submetidos as análises pertinentes. As análises microbiológicas revelaram ausência de Salmonella spp em $100 \%$ das amostras. Entretanto, 83,3\% das amostras analisadas apresentaram presença de coliformes totais, com populações superiores a 4 log UFC/g. Já as análises de coliformes termotolerantes evidenciaram um índice de contaminação de 37,5\%, com populações superiores a $4 \log \mathrm{UFC} / \mathrm{g}$, das quais, 8,33\% foram confirmados como Escherichia coli. Os resultados obtidos na presente pesquisa demonstram uma baixa qualidade higiênico-sanitária da carne bovina previamente moída ofertada pelos estabelecimentos comerciais amostrados do município de Cuiabá- MT, sendo o consumo desta, considerada um risco a saúde da população.

Palavras - chave: carne cominutada, qualidade de alimentos, contaminação. 


\section{INTRODUÇÃO}

A carne bovina é composta por nutrientes essenciais à saúde humana, garantindo a regulação dos processos fisiológicos e metabólicos do corpo humano. Por se tratar de um alimento rico em nutrientes, a carne bovina é considerada um excelente meio de cultura para o crescimento de microrganismos, devendo-se considerar também, sua composição química, elevada atividade de água e pH próximo à neutralidade, fatores que podem contribuir para o desenvolvimento microbiano (DORTA et al., 2014). Segundo Ferreira e Simm (2012), uma vez moída, torna-se mais susceptível a contaminação, em virtude do aumento de sua superfície de contato, bem como por sofrer maior manipulação.

Para Evangelista (2005), os moedores e utensílios de corte dos estabelecimentos comercializadores de carnes podem auxiliar como fonte de contaminação, pois, geralmente não passam pelo processo de limpeza e sanitização na frequência recomendada. Algumas etapas posteriores com o transporte, inadequação dos processos de refrigeração, a subdivisão das peças, sucessivos processos de congelamento e descongelamento, exposição ao ar e ao ambiente, se tornam importantes fontes de contaminação em carnes. Portanto, é necessário a adoção de boas práticas de higiene, boas instalações e cuidados por parte dos manipuladores para garantir um produto final de boa qualidade microbiológica.

De acordo com a Instrução Normativa n. 83 de 21 de novembro de 2003 (BRASIL, 2003), entende-se por carne moída o produto cárneo obtido a partir da moagem das massas musculares de carcaças de bovinos, seguido de resfriamento ou congelamento. Tal produto faz parte da dieta dos brasileiros de todas as camadas sociais, de qualquer faixa etária, pois este pode ser utilizado na elaboração de refeições bem como em recheios para diferentes tipos de salgados. Assim, além do fato de ser amplamente consumida por diferentes camadas da população, merece especial atenção por ser um produto extremamente manipulado, configurando assim risco à saúde pública quando princípios de boas práticas de manipulação não são adequadamente aplicados.

A legislação nacional referente aos padrões microbiológicos a serem adotados em alimentos é preconizada pela RDC $\mathrm{N}^{\circ} 12$, de 2 de Janeiro de 2001 (BRASIL, 2001). Tal legislação, estabelece para carne e produtos cárneos resfriados ou congelados "in natura", a ausência de Salmonella spp., em 25g, não comtemplando outros microrganismos indicadores de falhas de boas práticas de fabricação, sendo desta forma, permissiva no que se refere as demais micro-organismos que eventualmente estejam presentes em tais produtos.

Para Silva Júnior (2001), a sanidade da matéria-prima, a higiene no manuseio, as condições de fabricação e conservação e a limpeza dos equipamentos são fatores importantes que estão ligados diretamente à qualidade dos produtos cárneos. Este afirma que, quando em conformidade, são ferramentas de suma importância no intuito de garantir a inocuidade do produto e evitar a ocorrência de doenças transmitidas por alimentos. Dorta et al. (2014), também consideram que além destas ferramentas a análise microbiológica da carne, permite avaliar os processos de produção, quanto às condições higiênicosanitárias durante o processamento, estocagem e comercialização do produto.

Segundo Nascimento et al. (2014), a carne bovina moída apresenta um potencial de contaminação destacável em virtude de ser, muitas vezes, proveniente de retalhos de outras carnes e sofrer grande manipulação em seu processamento, além de comumente, permanecerem em temperatura ambiente por longos períodos. Esses fatores favorecem a multiplicação de uma microbiota normal composta predominantemente por bactérias Gram-negativas da família Enterobacteriaceae e do gênero Pseudomonas e por Gram-positivas dos gêneros Enterococcus, Lactobacillus e Staphylococcus, propiciam o aparecimento de bactérias patogênicas como Clostridium perfringens, S. aureus, Salmonella sp., alguns sorotipos de Escherichia coli e, ocasionalmente, Yersinia enterocolitica, Clostridium botulinum e Bacillus cereus. Para Jay (2005), por ser um produto amplamente consumido por todas as camadas sociais, tornase fundamental a preocupação e monitoramento da sua qualidade higiênico-sanitária.

Visando a segurança dos alimentos, além da pesquisa de Salmonella spp, estabelecido pela RDC n. 12, a contagem de coliformes termotolerantes, tem sido utilizada para avaliar as condições higiênico-sanitárias dos alimentos, uma vez que altas contagens desses microrganismos indicam falhas higiênicas ao longo do processamento e possibilidade da presença de microrganismos patogênicos (NASCIMENTO et al., 2014).

Assim, o presente trabalho objetivou avaliar a qualidade microbiológica da carne bovina moída comercializada em supermercados do Município de Cuiabá - MT, através da estimativa de Coliformes Totais, Coliformes Termotolerantes, Escherichia coli, Salmonella ssp, Mesófilos, pela técnica de Logarítmico (log). 


\section{MATERIAL E MÉTODOS}

Foram analisadas 24 amostras de carne bovina moída, colhidas entre os meses de março a junho de 2016 em quatro supermercados do Município de Cuiabá - MT, sendo os estabelecimentos identificados sequencialmente por números. As colheitas foram realizadas simulando-se a compra do produto por um consumidor, de aproximadamente $400 \mathrm{~g}$. Em seguida, foram acondicionadas em caixa térmica com gelo, não ultrapassando o tempo de 30 minutos após a colheita da amostra e início das análises.

Estas, foram realizadas no laboratório de Higiene e Tecnologia de Pescado da Universidade Federal de Mato Grosso, onde foram avaliados os seguintes microrganismos patogênicos e deteriorantes: Aeróbios Mesófilos, Aeróbios Psicrotróficos, Coliformes Totais, Coliformes Termotolerantes, Escherichia coli e Salmonella spp.

Todas as análises foram realizadas pelo método da American Public Health Association (APHA), descrito na $4^{\mathrm{a}}$ edição do Compendium of Methods for the microbiological Examination of Foods (Kornacki; Johnson, 2001), exceto para Salmonella spp. onde foi utilizado o método ISO 6579 (2007).

Adotou-se a metodologia preconizada por Kornacki e Johnson (2001) para enumeração de coliformes totais, termotolerantes e identificação de E. coli.

\section{RESULTADOS E DISCUSSÕES}

0 regulamento técnico de identidade e qualidade de carne moída de bovino, estabelecido pelo Ministério da Agricultura, Pecuária e Abastecimento (BRASIL, 2003), que tem a função de fixar a identidade e as características mínimas de qualidade do produto em questão, estabelece que o referido produto deve ser mantido à temperatura de $0^{\circ} \mathrm{C}$ a $4^{\circ} \mathrm{C}$. A baixa temperatura é um dos fatores primordiais para assegurar a qualidade microbiológica da carne moída, bem como aumentar sua vida de prateleira. Apesar disso, em alguns estabelecimentos amostrados, a carne já moída era armazenada em temperatura ambiente, dispostas acima dos balcões frigoríficos e não em seu interior, propiciando ambiente favorável ao crescimento de bactérias deteriorantes e ou patogênicas. Assim, a ausência de protocolos efetivos de Boas Práticas de Fabricação (BPF) em todas as etapas do processamento do produto na maioria dos estabelecimentos comerciais que recebem, manipulam e revendem carne in natura, causa um impacto negativo na qualidade sanitária do produto ofertado ao consumidor final.

Outro fator que merece destaque, interferindo diretamente na qualidade da carne, refere-se a descontinuidade da cadeia do frio. Etapa esta que se inicia ainda no transporte do produto até os estabelecimentos comerciais, a ausência de fiscalização da efetiva utilização dos caminhões frigoríficos com temperatura controlada durante o transporte, bem como as oscilações de temperatura nos locais de estocagem e comercialização nos locais de revenda, favorecem a contaminação microbiana. Em experimento realizado por Oliveira et al. (2008), algumas amostras alcançaram até $14^{\circ} \mathrm{C}$, expondo o produto a constantes variações de temperatura, diminuindo assim sua vida de prateleira.

No Brasil, os padrões microbiológicos a serem adotados em alimentos está regulamentado na Resolução de Diretoria de Colegiado - RDC, $\mathrm{n}^{\circ} 12$, de 2 de Janeiro de 2001. Nesta legislação, para carne e produtos cárneos resfriados ou congelados "in natura", preconiza-se apenas ausência de Salmonella spp., em 25g de alimento (BRASIL, 2001). Neste estudo todas as amostras analisadas apresentaram-se isentas de contaminação por Salmonella spp., sendo assim, ao avaliarmos exclusivamente a referida legislação, $100 \%$ das amostras estariam aptas para o consumo humano. Entretanto, os resultados encontrados pra os demais microrganismos pesquisados, indicam possíveis falhas durante a cadeia de processamento do produto. Como não há um padrão estabelecido para outros microrganismos no produto pesquisado, as demais análises efetuadas neste estudo, aeróbios mesófilos, fungos filamentosos e leveduras, coliformes totais e termotolerantes, Escherichia coli, foram realizadas somente como indicativo de higiene e boas práticas de fabricação.

Um estudo realizado por Costa et al. (2000), também verificaram ausência de Salmonella spp. em 25 amostras de carne moída comercializadas em supermercados de São Luís - MA. Resultados semelhante foram encontrados por Abreu et al. (2011), ao avaliarem 10 amostras de carne moída de supermercados do município de Umuarama - PR, demonstrando ausência de Salmonella spp. em 100\% das amostras analisadas.

Já em uma pesquisa realizada em supermercados, açougues e feiras livres na cidade de Belém/PA, Xavier e Joele (2004) encontraram a presença de Salmonella spp em 3,3\% (1 amostra) das 30 amostras de carne bovina analisadas em diversos cortes. Segundo Franco e Landgraf (2004), presença desse patógeno no 
alimento pode causar consequências graves ao consumidor principalmente para aqueles em que o sistema imunológico se encontra fragilizado podendo até mesmo levar ao óbito em casos mais graves.

Tais resultados já eram esperados, tanto na presente pesquisa como na dos autores supra citados, uma vez que por ser uma bactéria que tem seu crescimento limitado quando há uma alta contaminação por outros microrganismos. Os resultados desta pesquisa apresentaram uma contaminação relativamente alta para bactérias do gênero coliformes, dificultando assim a sobrevivência da Salmonella spp. nas amostras analisadas.

Já os resultados para contaminação por microrganismos aeróbios mesófilos, estão expressos na Tabela 1. Nesta, é possível verificar que todos os estabelecimentos avaliados obtiveram o número de microrganismo aeróbios mesófilos acima de $4 \log$ UFC/g. Embora legislação brasileira vigente (BRASIL, 2001), não estabeleça padrão de tolerância para esse grupo de microrganismo, tais resultados demonstram falhas de higiene na obtenção e manipulação do produto aliado a má qualidade da matéria prima.

Tabela 1: Resultados das contagens em números logaritmos de bactérias heterotróficas aeróbias mesófilas, presentes em amostras de carne bovina moída, coletadas em quatro supermercados de Cuiabá, MT.

\begin{tabular}{|c|c|c|c|c|}
\hline Repetição & Mercado 1 & Mercado 2 & Mercado 3 & Mercado 4 \\
\hline 1 & 6,07 & 6,81 & 6,4 & 6,3 \\
\hline 2 & 6,96 & 8,64 & 8 & 7,25 \\
\hline 3 & 7,61 & 7,01 & 8,77 & 8,28 \\
\hline 4 & 6,05 & 6,18 & 6,33 & 6,67 \\
\hline 5 & 7,25 & 7,09 & 8,94 & 8,29 \\
\hline 6 & 6,67 & 6,29 & 8,1 & 4,3 \\
\hline
\end{tabular}

Na Tabela 2 estão expressos os resultados identificados na presente pesquisa para bactérias do grupo coliformes totais. Assim, 83,3\% das amostras analisadas apresentaram populações superiores a $4 \log$ UFC/g, demonstrando com isso a precariedade higiênica na obtenção e manipulação do produto nos estabelecimentos comerciais em que estas amostras foram colhidas. Ao compararmos os resultados da presente pesquisa com os de Livoni et al. (2013), ao avaliar a qualidade higiênico sanitária de carne moída no estado Paraná, observaram valores também muito alarmantes, uma vez que tais autores encontraram a presença de coliformes totais em $100 \%$ das amostras analisadas.

Já as análises de coliformes termotolerantes evidenciaram um índice de contaminação de 37,5\%, apresentando populações superiores a 4 log UFC/g. Á partir da presença de termotolerantes foi possível efetuar a enumeração de Escherichia coli, e constatar que este microrganismo foi encontrado em 8,33\%, com populações superiores a estabelecida neste estudo.

Este grupo de enterobactérias está presente não somente no trato intestinal de homens e animais, mas também na água e no ambiente de um modo geral, sobretudo em locais de manipulação e processamento de alimentos onde a higiene é insatisfatória. 0 que provavelmente contribuiu para os resultados foi o fato de, em todos os locais de comercialização, ter sido observada práticas inadequadas de manipulação e higiene de mesas e utensílios. A presença de amostras contaminadas por coliformes termotolerantes, e, sobretudo por Escherichia coli, em um produto amplamente consumido pelo brasileiro, é extremamente preocupante, uma vez que apresentavam elevado risco de causar enfermidades alimentares ao consumidor final. 
Tabela 2: Resultado das contagens em Logaritmos de Coliformes Totais, Coliformes Termotolerantes e Escherichia coli, presentes em amostras de carne bovina moída, coletadas em quatro supermercados de Cuiabá, MT.

\begin{tabular}{|c|c|c|c|c|}
\hline & Repetição & $\begin{array}{l}\text { Coliformes } \\
\text { Totais }\end{array}$ & $\begin{array}{c}\text { Coliformes } \\
\text { Termotolerantes }\end{array}$ & Escherichia coli \\
\hline \multirow{8}{*}{ Mercado 1} & 1 & 4,36 & 4,36 & 3,47 \\
\hline & 2 & 5,38 & 3,47 & 3,47 \\
\hline & 3 & 5,66 & 3,96 & 3,55 \\
\hline & 4 & 4,32 & 3,78 & 3,85 \\
\hline & 5 & 4,32 & 3,25 & 3,47 \\
\hline & 6 & 4,96 & 3,96 & 3,47 \\
\hline & 1 & 4,63 & 3,47 & 3,79 \\
\hline & 2 & 6,04 & 5,38 & 3,47 \\
\hline \multirow{6}{*}{ Mercado 2} & 3 & 6,04 & 4,36 & 3,47 \\
\hline & 4 & 6,04 & 3,96 & 3,47 \\
\hline & 5 & 6,04 & 3,96 & 4,04 \\
\hline & 6 & 6,04 & 4,55 & 3,79 \\
\hline & 1 & 5,38 & 4,63 & 3,47 \\
\hline & 2 & 6,04 & 6,04 & 3,47 \\
\hline \multirow{6}{*}{ Mercado 3} & 3 & 5,38 & 3,47 & 3,55 \\
\hline & 4 & 4,11 & 3,96 & 3,47 \\
\hline & 5 & 4,04 & 3,47 & 3,47 \\
\hline & 6 & 6,04 & 3,47 & 3,47 \\
\hline & 1 & 5,66 & 5,38 & 4,44 \\
\hline & 2 & 6,04 & 5,32 & 3,47 \\
\hline \multirow{4}{*}{ Mercado 4} & 3 & 6,04 & 3,96 & 3,47 \\
\hline & 4 & 3,47 & 3,77 & 3,47 \\
\hline & 5 & 3,65 & 3,47 & 3,47 \\
\hline & 6 & 4,63 & 4,36 & 3,47 \\
\hline
\end{tabular}

\section{CONCLUSÃO}

Diante dos resultados obtidos, conclui-se que apesar das amostras de carne moída analisadas estarem dentro dos padrões estabelecidos pela legislação nacional vigente quanto ao parâmetro microbiológico, ausência de Salmonella spp em $25 \mathrm{~g}$ de alimento, a elevada contaminação por fungos filamentosos, aeróbios mesófilos, bactérias do gênero coliformes, bem como a presença de E. coli, indicam condições higiênico-sanitárias insatisfatórias e consequentemente um risco em potencial ao consumidor.

Sabe-se que muitos fatores podem influenciar na qualidade sanitária de um produto de origem animal, entretanto, a ausência ou a ineficiência de aplicação das ferramentas de autocontrole tais como, Boas Práticas de Fabricação (BPF) e Programa Padrão de Higiene Operacional (PPHO), nos estabelecimentos comerciais que manipulam, processam ou fracionam o alimento, intensificam a perda de qualidade higiênico sanitária do mesmo.

\section{REFERÊNCIAS}

[1] ABREU, C.0; MERLINI, L. S; BEGOTTI, I. L. Pesquisa de Salmonella ssp, Staphylococcus aureus, coliformes totais e coliformes termo tolerantes em carne moída comercializada no município de Umuarama - Pr. Arquivo Veterinária Zoologia. UNIPAR, Umuarama. V.14. n 1. p. 19-23, 2011.

[2] BRASIL. Agência Nacional de Vigilância Sanitária. Resolução no12 de janeiro de 2001. Aprova o Regulamento Técnico sobre Padrões Microbiológicos para alimentos. Diário Oficial da União, Poder Executivo, de 10 de janeiro de 2001. Disponível em: <http://www.anvisa.gov.br/legis/resol/12_01rdc.htm> Acesso em: 17 ago. 2016.

[3] BRASIL. Ministério da Agricultura, Pecuária e do Abastecimento. Instrução Normativa no 83 , de 21 de novembro de 2003. Regulamento Técnico de Identidade e Qualidade de Carne Moída de Bovino. Diário Oficial da União, 24 nov. 2003, Seção 1, p.29. Disponível em: <http://extranet.agricultura.gov.br/sislegis-consulta/ consultarLegislacao.do?operacao=visualizar\&id=4317 > Acesso em: 17 ago. 2016.

[4] COSTA, F.; ALVES, L.; MONTE, S.: Avaliação das condições higiênico-sanitárias de carne moída, comercializada na cidade de São Luís, MA. Revista Higiene Alimentar, São Paulo, v. 11, n.77, p. 49-52, 2000. Disponível em <http://www.ufrgs.br/actavet/32-1/artigo576.pdf> Acesso em: 20 de ago. de 2018. 
[5] DORTA, Claudia; KADOTA, Juliana C. P.; NAKAMATSU, Michelle S. I. Qualidade microbiológica de carnes bovinas embaladas a vácuo e das vendidas a granel. Revista Analytica, n. 74, p. 58-63, Dezembro 2014/Janeiro 2015.

[6] EVANGELISTA, José. Tecnologia de Alimentos. São Paulo: Editora Atheneu, 2005.

[7] FERREIRA, Rogério Santos; SIMM, Erny Marcelo. Análise microbiológica da carne moída de um açougue da região central do município de Pará de Minas/MG. SYNTHESIS| Revista Digital FAPAM, v. 3, n. 3, p. 37-61, 2016.

[8] FRANCO, B.D.G.M.; LANDGRAF, M. Microbiologia dos alimentos. São Paulo: Atheneu, 2008.

[9] JAY, J.M. (2005). Microbiologia dos alimentos. Porto Alegre: Artmed.

[10] KORNACKI, J. L., Johnson, J. L. (2001). Enterobacteriaceae, Coliforms, and Escherichia coli as quality and Safety Indicators. In: DOWNES, F. P; ITO, K. Compedium of Methods for the Microbiological Examination of foods. 4 ed. Washington: APHA. 676 p. cap. 8, p. 69-82.

[11] LIVONI. J. F. L. S., BEGOTTI. I. L., MERLINI. L. S. Qualidade higiênico-sanitária da carne bovina moída comercializada no município de Umuarama, PR., Brasil. Enciclopédia Biosfera, Centro Científico Conhecer - Goiânia, v.9, n.16, 2013.

[12] MARCHI, P. G. F. Estudo comparativo do estado de conservação de carne moída através de métodos microbiológicos e físico-químicos. Universidade Estadual Paulista, faculdade de ciências agrárias e veterinárias. Jaboticabal/São Paulo - Brasil, 2006.

[13] NASCimEnTO, M.V.D., Guedes, A.T. L., Silva, H. A., Santos, V.E. P., Paz, M.C.F. (2014). Revista Saúde e Ciência. Online; 3(1), 56-68.

[14] OliveirA, M. M. M., BRUGnerA, D. F., MENDONÇA, A. T., Piccoli, R. H. Condições Higiênico-sanitárias de Máquinas de Moer Carne, Mãos de Manipuladores e Qualidade Microbiológica da Carne Moída. Ciência e Agrotecnologia Lavras, v. 32, n. 6, p. 1893-1898, nov./dez, 2008.

[15] PARDI, M. C., Santos, I. F., Souza, E. R., Pardi, H. S. (1995). Ciência, higiene e tecnologia da carne: ciência e higiene da carne. Tecnologia da sua obtenção e transformação. Goiânia: UFG.

[16] SILVA JUNIOR, E. S. (2001). Manual de controle higiênico sanitário em alimentos. 4. ed. São Paulo: Varela.

[17] SILVA, W. P.; GANDRA, E. A. Staphylococcus Coagulase Positiva: patógenos de importância em alimentos. Revista Higiene Alimentar, São Paulo, v. 18, n. 122, 2004.

[18] XAVIER, Verushka Goldschimdt; JOELE, Márcia Regina Sarkis Peixoto. Avaliação das condições Sanitárias da Carne Bovina In Natura Comercializada na Cidade de Belém, PA. Revista Higiene Alimentar. Belém, v. 18, n.125, p. 6474, out. 2004. 


\section{Capítulo 11}

Avaliação da atividade antimicrobiana de óleo essencial de Cravo-da-Índia (Syzigium aromaticum) obtido com $\mathrm{CO} 2$ em fase supercrítica

\section{Elaine Patrícia Tavares do Espírito Santo}

\section{Gardene Dourado Mota}

Alex Brito Souza

Silvia Helena Marques da Silva

Resumo: 0 interesse em compostos bioativos provenientes de espécies botânicas vem aumentando, devido às mesmas apresentarem potencialidades para prevenir e /ou tratar várias patologias. Muitas destas espécies botânicas são utilizadas na medicina popular e este conhecimento tradicional tem sido objeto de vários estudos. 0 emprego de metodologia de extração de compostos com fluído supercrítico (CO2) tem possibilitado obter compostos livre de solventes, promovendo melhor obtenção e desenvolvimento de compostos com propriedades farmacológicas. 0 extrato botânico obtido por meio da técnica de SFE a partir de botões florais de S. aromaticum tem apresentado excelente atividade antifúngica, principalmente contra espécies do gênero Trichosporon e Candida. 


\section{INTRODUÇÃO}

O interesse em compostos bioativos provenientes de espécies botânicas vem aumentando, devido às mesmas apresentarem potencialidades para prevenir e /ou tratar várias patologias, pois os produtos obtidos apresentam características etnofarmacológicas, cujo potencial biológico é conhecido na medicina popular, principalmente na região amazônica (Silva et al., 2007; Souza et al., 2008; Pereira et al., 2010; Fernandes et al., 2013; Pires et al., 2017).

0 uso de plantas para fins medicinais é tão antigo quanto à própria humanidade. Esses produtos são comercializados em feiras e mercados, ou até mesmo plantação residencial para consumo próprio. A experiência popular sobre a eficácia das plantas contribui para divulgação dos efeitos terapêuticos e no uso destes produtos naturais, sendo este conhecimento repassado por várias gerações (Maciel et al., 2002).

Plantas medicinais são todas as plantas que possuem uma ou mais substâncias biologicamente ativas, com propriedades terapêuticas ou que possam ser precursoras da síntese de fármacos (AGÊNCIA NACIONAL DE VIGILÂNCIA SANITÁRIA, 2004). Nos últimos anos aumentou a procura por uso de produtos naturais em substituição a fármacos sintéticos e conservantes de alimentos industrializados por produtos extraídos de plantas, como o óleo essencial (Ascenção \& Mouchrek Filho, 2013; Miranda et al., 2016).

Óleos essenciais são metabólitos secundários extraídos de plantas, com composição química complexa e exercem funções importantes na manutenção da espécie vegetal. Devido os seus constituintes, os óleos podem controlar a oxidação de alimentos e atividade contra bactérias resistentes aos antimicrobianos (Miranda et al., 2016). A presença de componentes com ação terapêutica possibilita a produção de medicamentos a partir de plantas, tornando importante alternativa no combate a microrganismos resistentes aos medicamentos comerciais (Filho \& Pereira, 2012).

\section{SYZYGIUM AROMATICUM E SUAS PROPRIEDADES}

Syzygium aromaticum, conhecido popularmente como cravo-da-índia, é uma planta nativa da Indonésia, sendo cultivada em muitos países pelo mundo. Os maiores produtores estão na Índia, Indonésia, Malásia, Sri Lanka, Madagascar e Tanzânia. No Brasil, a Bahia é o principal produtor, sendo estimada a produção de 2.500 toneladas de cravo seco ao ano (Cortés-Rojas et al., 2014; Kamatou et al., 2012).

Pertencente à família Myrtaceae, S. aromaticum é uma árvore sempre verde e de tamanho moderado (atinge altura entre 8 a 12 m), que vive cerca de 100 anos. Utilizada na extração industrial de seu óleo essencial a partir dos botões da flor (cravo), folhas e outros. São muito usados como remédios populares para problemas dentários, respiratório, dor de cabeça e dor de garganta. Há relatos na literatura que confirmam sua atividade antibacteriana, antifúngica, antiviral e anticarcinogênica (Ascenção \& Mouchrek Filho, 2013; Cortés-rojas et al., 2014; Kim \& Lee, 2012; Pinto et al., 2009).

$\mathrm{Na}$ Índia, o cravo é bastante utilizado pela medicina Ayurvédica, nos tratamentos respiratórios e problemas alimentares. Devido suas propriedades antissépticas e antibióticas são utilizados em preparações de dentifrícios caseiros e enxaguatórios bucais (Banerjee et al., 2006).

Figura 1 - Planta Syzygium aromaticum (cravo-da-índia), árvore (A) e botões florais (B e C).

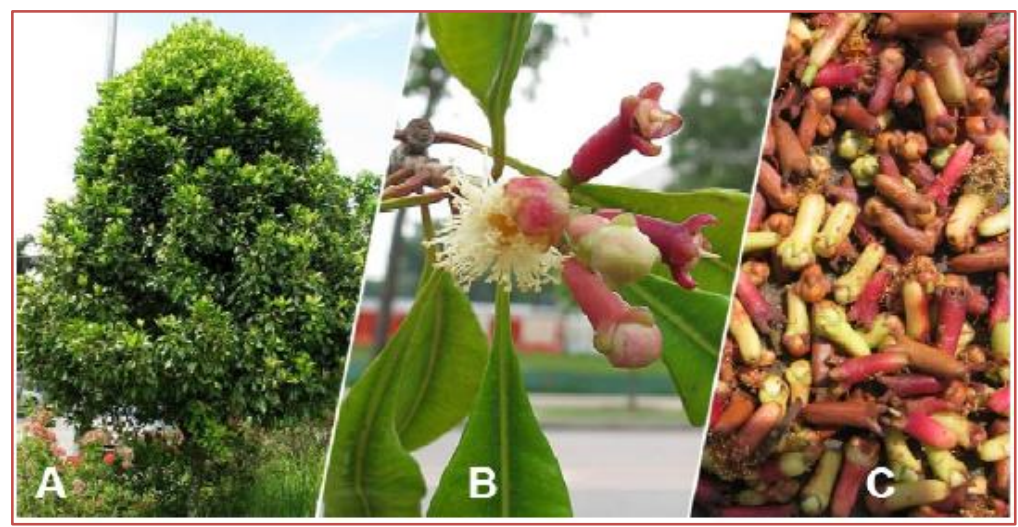

Fonte: http://www.plantasexoticas.com.br/cravo-da-india-eugenia-caryophyllata. 
Esta planta é rica em compostos fenólicos como, acetato de eugenol, ácido gálico e eugenol, seu principal componente (Cortés-rojas et al., 2014). Eugenol é um composto volátil, com várias propriedades farmacológicas, como: ação antioxidante, anestésico, anti-inflamatório, anticarcinogênico, antiespasmódico, antisséptico, antifúngico, inibidor da monoamina oxidase (MAO), possui efeitos neuroprotetores e excelente atividade bacteriana (Ascenção \& Mouchrek Filho, 2013; Raja et al, 2015).

A ação do óleo essencial de S. aromaticum sobre alguns patógenos fúngicos foi avaliado por Rana et al. (2011) que determinaram a seguinte escala de sensibilidade: Mucor sp. > Microsporum gypseum > Fusarium monoliforme $>$ Trichophyton rubrum $>$ Aspergillus sp. $>$ Fusarium oxysporum e atribuíram ao eugenol à propriedade antifúngica do óleo.

Espécies de Candida, Aspergillus e dermatófitos foram estudadas por Pinto et al. (2009) que demonstraram a atividade inibitória do óleo essencial e eugenol contra todas as cepas analisadas. Outros estudos relatam a ação do S. aromaticum sobre espécies de dermatófitos (Park et al., 2007) e sobre C. albicans, C. neoformans, Trichophyton mentagrophytes, Saccharomyces cerevisiae, A. niger e A. fumigatus (Ahmad et al., 2005; Affonso et al., 2012).

Eugenol apresenta potente atividade antibacteriana contra cepas Gram-positivas (ex.: Staphylococcus aureus, Steptococcus pyogenes) e Gram-negativas (ex.: Escherichia coli, Salmonella typhi); atividade antifúngica, em C. albicans por exemplo, altera a morfogênese potencializando a inibição da colonização e infectividade; atividade antiviral, como em vírus de herpes (HSV-1 e HSV-2) ao inibir a replicação e reduzir a infecção; antiparasitário, com ações em giárdia, Leishmania e outros (Raja et al, 2015).

Devi et al. (2010) avaliaram a atividade e o modo de ação do eugenol sobre S. typhi relatando que este composto possui ação bactericida e bacteriostática, sugerindo a sua interação com a membrana celular, causando aumento da permeabilidade e, consequentemente, morte do microrganismo.

Chami et al. (2004) avaliaram a atividade anti-Candida de eugenol e carvacrol em modelo de candidiase vaginal e sugerem que ambos podem ser antifúngicos promissores para o tratamento e profilaxia de candidiase vaginal. Eugenol também possui atividade antibacteriana sobre cepas de Helicobacter pylori, demonstrada por Ali et al. (2005). Estes estudos permitem sugerir uma nova alternativa terapêutica para o tratamento de infecções fúngicas, assim os óleos essenciais são de grande importância por apresentar atividades antimicrobiana, analgésica, sedativa e anti-inflamatória.

\section{EXTRATO DE SYZYGIUM AROMATICUM: MÉTODO DE EXTRAÇÃO E ATIVIDADE ANTIFÚNGICA}

Para obtenção de óleos essenciais, há várias técnicas disponíveis, como: destilação por arraste a vapor, hidrodestilação, extração por solventes orgânicos, entre outras (Arranz et al., 2015; Bakkali et al., 2008). A técnica de extração que vem se destacando nos últimos anos, é a extração por fluido supercrítico (SFE Supercritical Fluid Extraction) com dióxido de carbono (CO2). Considerada uma técnica rápida e de alta eficiência, com desempenho a temperaturas relativamente baixas e evita a utilização de solventes orgânicos, que são prejudiciais ao meio ambiente (Arranz et al., 2015; Maul, 1999).

Díaz - Maroto et al. (2002) compararam a técnica de SFE com destilação para obtenção de óleos essenciais de três especiarias diferentes (orégano, manjericão e hortelã) demonstrando que os óleos possuiam composição semelhante, porém o rendimento foi maior com a SFE. Além de menor tempo de processo e preservação das características naturais do extrato por não ocorrer degradação térmica e nem contaminação com o solvente.

A SFE iniciou-se, em escala industrial, no final dos anos 70 na Alemanha, com o processo de remoção da cafeína do café. Esta técnica vem sendo bastante utilizada, pois é considerada uma técnica limpa, segura, barata, seletiva, não produz resíduos tóxicos, não altera as propriedades da matéria-prima, não poluente e proporciona a obtenção seletiva de compostos bioativos com elevada qualidade (Dias et al., 2013; Moura et al., 2005; Maul, 1999).

A extração pode ser controlada através da ampla faixa de condições de temperatura e pressão empregados no processo. $0 \mathrm{CO} 2$ é o mais utilizado na extração supercrítica, por apresentar ponto crítico relativamente baixo (temperatura crítica $=31,04^{\circ} \mathrm{C}$ e pressão crítica $=73,8$ bar). Além disso, dissipa-se totalmente no final do processo não necessitando de etapa adicional para remoção de solventes (Díaz - Maroto et al., 2002).

Outras vantagens do CO2 são: não tóxico, não inflamável, não reage com os componentes do extrato, quimicamente estável e seguro. 0 CO2 supercrítico apresenta densidade próxima de um líquido, baixa 
viscosidade e se difunde como gás, conferindo-lhe excelentes qualidades de extração (Díaz - Maroto et al., 2002; Maul, 1999).

Os compostos extraídos com CO2 são não polar ou com baixas polaridades, tais como os óleos essenciais e ceras extraídos basicamente de folhas e flores, enquanto que compostos como óleos vegetais e gorduras são extraídos de sementes (Sovová, 2012).

Em estudo desenvolvido no Instituto Evandro Chagas (IEC)/Secretaria de Vigilância em Saúde (SVS)/Ministério da Saúde (MS) em parceria com o Laboratório de Extração da Faculdade de Engenharia de Alimentos (FEA), do Instituto de Tecnologia (ITEC) da Universidade Federal do Pará (UFPA) extrato de S. aromaticum tem sido obtido por meio da SFE e testado contra diferentes espécies de leveduras com o objetivo de avaliar a atividade antimicrobiana deste extrato.

A atividade antifúngica do extrato obtido por meio da SFE foi avaliada por meio do método de discodifusão em meio sólido com modificações (CLSI, 2004), em isolados de Trichosporon asahii, T. inkin, T. faecale, T. coremiiforme e T. japonicum, C. albicans e Candida não-albicans (C. parapsilosis, C. tropicalis, C. haemulonii, C. sake, C. krusei e C. melibiosica), onde se observou sensibilidade de todos os isolados ao S. aromaticum, apresentando halos que variaram de $22 \mathrm{~mm}$ a $36 \mathrm{~mm}$ para espécies de Trichosporon e 19 mm a $41 \mathrm{~mm}$ para espécies de Candida (Figura 2). A Concentração Inibitória Mínima (CIM) foi determinada por meio da técnica de microdiluição em caldo (CLSI, 2002). As concentrações de $0.03 \%$ a 2.5\% do extrato se mostraram satisfatórias para inibir espécies de Trichosporon e $0.08 \%$ a $0.63 \%$ para inibir espécies de Candida. Assim, podemos confirmar a potencialidade de ação do extrato sobre espécies do gênero Trichosporon e Candida, e sua importância como indicação de composto para compor formulações que possam ser utilizadas no tratamento de infecções causadas pelas espécies fúngicas testadas. Além disso, a ação do componente majoritário, Eugenol, foi avaliada sobre as mesmas espécies fúngicas e estas apresentaram alta sensibilidade ao composto, com halos de inibição variando de $20 \mathrm{~mm}$ a $45 \mathrm{~mm}$ para Trichosporon, 22.5 a $43.3 \mathrm{~mm}$ para Candida (Figura 3). Assim, o extrato de S. aromaticum obtido por SFE e o seu componente majoritário, o Eugenol, possuem ótima atividade anti-fúngica sobre espécies de Trichosporon e Candida.

Figura 2 - Ação do extrato de Syzygium aromaticum (Cravo-da-Índia) obtido via CO2 supercrítico, sobre isolados de Trichosporon (A) e Candida (B).
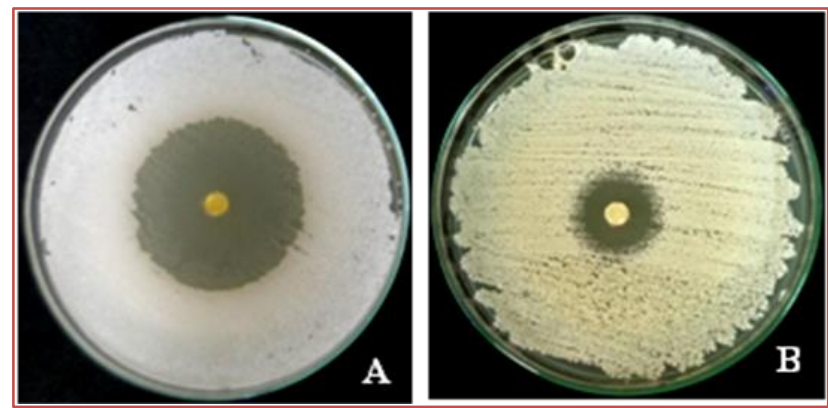

Fonte: Autores.

Figura 3 - Ação do Eugenol sobre isolados de Trichosporon (A) e Candida (B).

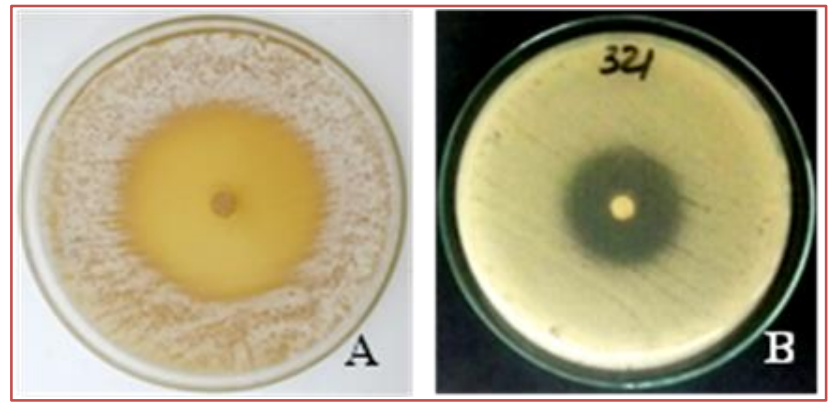

Fonte: Autores. 


\section{PERSPECTIVAS FUTURAS}

A metodologia de extração com fluído supercrítico (CO2) abre caminho para a obtenção e estudo de novos compostos que apresentam propriedades farmacológicas, principalmente em espécies botânicas oriundas da região amazônica. Estas podem ser caracterizadas melhor e o conhecimento popular associado pode ser mais bem aplicado.

\section{REFERÊNCIAS}

[1] AHMAD, N., ALAM, M.K., SHEHBAZ, A., KHAN, A., MANNAN, A., HAKIM, S.R., BISHT, D., OWAIS, M. Antimicrobial activity of clove oil and its potential in the treatment of vaginal candidiasis. Journal of Drug Targeting 13 (10): 555-561, 2005.

[2] AFFONSO, R. S.; RENNO, M. N.; SLANA, G. B. C. A.; FRANCA, T. C. C. Aspectos

[3] Químicos e Biológicos do Óleo Essencial de Cravo da Índia. Revista Virtual de Química 4 (2): 146-161, 2012.

[4] AGÊNCIA NACIONAL DE VIGILÂNCIA SANITÁRIA. Resolução RDC n 48, de 16 de março de 2004. Dispõe sobre o registro de medicamentos fitoterápicos.

[5] ALI, S.M., KHAN, A.A., AHMED, I., MUSADDIQ, M., AHMED, K.S., POLASA, H., RAO, L.V., HABIBULLAH, C.M., SECHI, L.A., AHMED, N. Antimicrobial activities of eugenol and cinnamaldehyde against the human gastric pathogen Helicobacter pylori. Annals of Clinical Microbiology Antimicrobials 4:20-24, 2005.

[6] ARRANZ, E., JAIME, L., LÓPEZ DE LAS HAZAS, M.C., REGLERO, G., SANTOYO, S. Supercritical fluid extraction as an alternative process to obtain essential oils with anti-inflammatory properties from marjoram and sweet basil. Industrial Crops and Products 67: 121-129, 2015.

[7] ASCENÇÃO, V.L. \& MOUCHREK FILHO, V.E. Extração, Caracterização Química e Atividade Antifúngica de óleo essencial Syzygium aromaticum (cravo da índia). Cadernos de Pesquisa, São Luís, v. 20, n. especial, julho 2013.

[8] BAKKALI, F., AVERBECK, S., AVERBECK, D., IDAOMAR, M. Biological effects of essential oils - A review. Food and Chemical Toxicology 46: 446-475, 2008.

[9] BANERJEE, S.; PANDA, C.K.; DAS, S. Clove (Syzygium aromaticum L.), a potential chemopreventive agent for lung cancer. Carcinogenesis, 27 (8): 1645-1654, 2006

[10] CHAMI, F., CHAMI, N., BENNIS, S., TROUILLAS, J., REMMAL, A. Evaluation of carvacrol and eugenol as prophylaxis and treatment of vaginal candidiasis in an immunosuppressed rat model. Journal of Antimicrobial Chemotherapy 54: 909-914, 2004.

[11] CLSI. Method for Antifungal Disk Diffusion Susceptibility Testing of Yeasts; Approved Guideline. CLSI document M44-A (ISBN 1-56238-532-1). CLSI, 940 West Valley Road, Suite 1400, Wayne, Pennsylvania 19087-1898 USA, 2004.

[12] CLSI/NCCLS - Método de Referência para Testes de Diluição em Caldo para a Determinação da Sensibilidade a Terapia Antifúngica das Leveduras. Norma Aprovada - Segunda edição. Norma M27-A2 do NCCLS. Wayne, Pennsylvania, 2002.

[13] CORTÉS-ROJAS, D.F., DE SOUZA, C.R.F., OLIVEIRA, W.P. Clove (Syzygium aromaticum): a precious spice. Asian Pacific Journal of Tropical Biomedicine 4(2): 90-96, 2014.

[14] DEVI, K.P., NISHA, S.A., SAKTHIVEL, R., PANDIAN, S.K. Eugenol (an essential oil of clove) acts as an antibacterial agent against Salmonella typhi by disrupting the cellular membrane. Journal of Ethnopharmacology 130: 107-115, 2010.

[15] DIAZ-MAROTO, M.C., PÉREZ-COELHO, M.S., CABEZUDO, M.D. Supercritical carbon dioxide extraction of volatiles from spices comparison with simultaneous distillation-extraction. Journal of Cromatography A 947: 23-29, 2002.

[16] DIAS, A.M.A., REY-RICO, A., OLIVEIRA, R.A., MARCENEIRO, S., ALVAREZ-LORENZO, C., CONCHEIRO, A., JUNIOR, R.N.C., BRAGA, M.E.M., DE SOUSA, H.C. Wound dressings loaded with an anti-inflammatory juca (Libidibia ferrea) extract using supercritical carbon dioxide technology. The Journal of Supercritical Fluids 74: 34- 45, 2013.

[17] FERNANDES, F.H.A, SANTANA, C.P., SANTOS, R.L., CORREIA, L.P., CONCEIÇÃO, M.M., MACÊDO, R.O., MEDEIROS, A.C.D. Thermal characterization of dried extract of medicinal plant by DSC and analytical techniques. Journal of Thermal Analysis and Calorimetry 113: 443-447. 2013.

[18] FILHO, A.L.M. \& PEREIRA, M.R.R. Antimicrobial activity of açaí and pupunha oils on the Development of Pseudomonas aeruginosa and Staphylococcus aureus. Bioscience Journal 28 (4): 598-603, 2012.

[19] KAMATOU, G.P., VERMAAK, I., VILJOEN, A.M. Eugenol—From the Remote Maluku Islands to the International Market Place: A Review of a Remarkable and Versatile Molecule. Molecules 17: 6953-6981, 2012. 
[20] KIM, Y. \& LEE, H. Anticandidal effect of Syzygium aromaticum on biofilm formation, cell surface hydrophobicity, and cell cycle. Journal of Medicinal Plants Research 6 (10): 1926-1934, 2012.

[21] MACIEL, M.A.M., PINTO, A.C., VEIGA JR, V.F., GRYNBERG, N.F., ECHEVARRIA, A. Plantas medicinais: a necessidade de estudos multidisciplinares. Química. Nova 25 (3): 429-438, 2002.

[22] MAUL, A.A. Fluidos Supercríticos, situação atual e futuro da extração supercrítica. Biotecnologia Ciência \& Desenvolvimento 11: 42-46, 1999.

[23] MIRANDA, C.A.S.F., CARDOSO, M.G., BATISTA, L.R., RODRIGUES, L.M.A., FIGUEIREDO, A.C.S. Óleos essenciais de folhas de diversas espécies: propriedades antioxidantes e antibacterianas no crescimento espécies patogênicas. Revista Ciência Agronômica 47 (1): 213-220, 2016.

[24] MOURA, L.S., CARVALHO JR, R.N., STEFANINI, M.B., MING, L.C., MEIRELES, M.A.A. Supercritical fluid extraction from fennel (Foeniculum vulgare): global yield, composition and kinetic data. The Journal of Supercritical Fluids 35: 212-219, 2005.

[25] PARK, M.J., GWAK, K.S., YANG, I., CHOI, W.S., JO, H.J., CHANG, J.W., JEUNG, E.B., CHOI, I.G. Antifungal Activities of the Essential Oils in Syzygium aromaticum (L.) Merr. Et Perry and Leptospermum petersonii Bailey and their Constituents against Various Dermatophytes. The Journal of Microbiology 45 (5): 460-465, 2007.

[26] PINTO, E., VALE-SILVA, L., CAVALEIRO, C., SALGUEIRO, L. Antifungal activity of the clove essential oil from Syzygium aromaticum on Candida, Aspergillus and dermatophyte species. Journal of Medical Microbiology 58: 1454$1462,2009$.

[27] PEREIRA, C.G. \& MEIRELES, M.A.A. Supercritical fluid extraction of bioactive compounds: fundamentals, applications and economic perspectives. Food and Bioprocess Technology 3: 340-72. 2010.

[28] PIRES, F. C. S.; ALMEIDA, M. M.; SILVA, A. P. S.; SALAZAR, M. A. R.; URBINA, G. R. O.; SILVA, P. S.; SILVA, S. G.; BEZERRA, P. N.; MARQUES- DA -SILVA, S. H.; CARVALHO JUNIOR, R. N..Therapeutic potential of extracts from Amazonian plants with antimicrobial activity. Antimicrobial research: Novel bioknowledge and educational programs (A. Méndez-Vilas, Ed.) 504-515.2017.

[29] RANA, I.S., RANA, A.S., RAJAK, R.C. Evaluation of antifungal activity in essential oil of the Syzygium aromaticum (l.) by extraction, purification and analysis of its main component eugenol. Brazilian Journal of Microbiology 42: 1269-1277, 2011.

[30] RAJA, M.R.C., SRINIVASAN, V., SELVARAJ, S., MAHAPATRA, S.K. Versatile and Synergistic Potential of Eugenol: A Review. Pharmaceutica Analytica Acta 6:5, 2015.

[31] SILVA, E.M., SOUZA, J.N.S., ROGEZ, H., REES, J.F., LARONDELLE, Y. Antioxidant activities and polyphenolic contents of fifteen selected plant species from the Amazonian region. Food Chemistry. 101:1012-18. 2007.

[32] SOUZA, J.N.S., SILVA, E.M., LOIR, A., REES, J.F., ROGEZ, H., LARONDELLE, Y. Antioxidant capacity of four polyphenol- rich Amazonian plant extracts: A correlation study using chemical and biological in vitro assays. Food Chemistry 106: 331-39. 2008

[33] SOVOVÁ, H. Steps of supercritical fluid extraction of natural products and their characteristic times, The Journal Supercritical Fluids 66: 73-79, 2012. 


\section{Capítulo 12}

Avaliação de microrganismos indicadores higiênicosanitários e pesquisa de Salmonella sp. em queijos parmesão ralados comercializados em campos dos Goytacazes - RJ

Silvia Menezes de Faria Pereira

Gabriela Vigneron Aguiar

Clara dos Reis Nunes

João Batista Barbosa

Simone Vilela Talma

Resumo: Os queijos, dentre os derivados do leite, são os mais suscetíveis à contaminação e o queijo parmesão, que é consumido principalmente na sua forma ralada, é um dos alimentos mais fraudados. As intoxicações alimentares são causadas por microrganismos patogênicos e por isso a importância da análise desses microrganismos nos alimentos que consumimos diariamente. A qualidade do alimento deve ser garantida desde o recebimento de matéria prima até a mesa do consumidor, e uma das maneiras de se obter isso é através das boas práticas de fabricação. Desta maneira, o objetivo deste trabalho foi avaliar os microrganismos indicadores higiênico-sanitário e detectar presença ou ausência de Salmonella sp em amostras de queijos parmesão ralado disponíveis no comércio da cidade de Campos dos Goytacazes - RJ. 0 presente estudo classificado como pesquisa observacional transversal, foi feito com 15 amostras de queijos parmesão ralados para contagem de coliformes totais e termotolerantes e pesquisa de Salmonella sp. Todas as amostras apresentaram aptas para consumo, com resultados dentro dos limites especificados dentro da legislação. Em três amostras (20\%) de mesma marca, observou-se contagem para coliformes totais e termotolerantes, e não houve crescimento de Salmonella sp em todas as amostras. É importante considerar que os resultados sugerem falhas no processo de fabricação reafirmando então que deve-se ter um maior cuidado durante a produção do mesmo.

Palavras-chave: queijo parmesão, microrganismos patogênicos, Salmonella sp 


\section{INTRODUÇÃO}

O queijo possui alto valor nutritivo sendo muito empregado na culinária, e bastante consumido na mesa brasileira, por todas as classes sociais. Porém, por ser um produto perecível, durante a sua produção ele pode sofrer contaminações das mais variadas origens, o que deixa alerta em relação à saúde dos consumidores1.

Dentre os derivados do leite os queijos são mais suscetíveis à contaminação, devido seus vários processos envolvidos na fabricação como, pasteurização do leite, coagulação, corte do coágulo, retirada do soro, enformagem, salga, maturação e embalagem2.

Existem muitos tipos de queijo, sendo um deles o queijo parmesão. "Entende-se por queijo parmesão, o queijo maturado que se obtém por coagulação do leite por meio do coalho e/ou outras enzimas coagulantes apropriadas, complementada pela ação de bactérias lácticas específicas" 3 . Para manter suas características como, cor branca amarelada e ligeiramente amarelada, com sabor salgado e levemente picante ele deve ser armazenado a uma temperatura não superior a $25^{\circ} \mathrm{C} 4$.

0 "queijo parmesão ralado" poderá apresentar como ingredientes, além do queijo parmesão, até $25 \%$ $\mathrm{m} / \mathrm{m}$ de outras variedades de queijos de baixa umidade. Ele pode ser classificado como desidratado ou não e ainda pela variedade de queijo de baixa umidade ou com queijo de média umidade5.

O queijo parmesão, na grande maioria das vezes, consumido na sua forma ralada, é um dos produtos mais fraudados. No queijo ralado, o esfarelamento ou ralagem da massa, pode apresentar até quatro variedades de queijos aptos para o consumo humano5.

A lactose interage de diferentes maneiras com os outros componentes também distribuídos no queijo, apresentando elevada complexidade o que pode afetar a qualidade do produto final6.

o queijo parmesão ralado é passível de apresentar microrganismos indesejáveis, já que sua matéria prima é uma excelente fonte de nutrientes, se trata de um alimento processado e perecível. Porém, alguns microrganismos podem estar em níveis inaceitáveis estabelecidos pela legislação vigente, os quais indicam se o alimento é apropriado ou não para consumo.

Alguns microrganismos patogênicos também podem ser encontrados nos laticínios e são eles os responsáveis pelas intoxicações alimentares, devido às toxinas que formam durante as fases de processamento e armazenamento dos produtos7.

Avaliar a presença de microrganismos em alimentos tem grande importância devido os perigos que as doenças transmitidas por alimentos (DTA) podem trazer à saúde humana.

Os coliformes totais e termotolerantes estão dentro do grupo de microrganismos indicadores higiênicosanitários. A presença deste grupo em alimentos processados é considerada uma indicação de contaminação pós-sanitização ou pós-processo, evidenciando práticas de higiene e sanitização abaixo dos padrões exigidos para o processamento de alimentos8. A presença de coliformes termotolerantes é indicadora da probabilidade do contato do alimento com material de origem fecal.

Outro gênero de fundamental importância é o gênero Salmonella. Os produtos lácteos são importantes veículos de transmissão de Salmonella sp, e tanto em países desenvolvidos como em desenvolvimento, é um microrganismo que está dentre os agentes patogênicos mais frequentemente encontrados em surtos de DTAs9.

Quanto aos critérios microbiológicos, os limites aceitos para queijos de baixa umidade são de $5 \times 102$ para coliformes a $45^{\circ} \mathrm{C} / \mathrm{g}$, ausência de Salmonella sp/25g e 103 para Estafilococcus coagulase positiva. Para queijos de média umidade, os limites são de 103 para coliformes a $45^{\circ} \mathrm{C}$, ausência de Salmonella sp/25g e 103 para Estafilococcus coagulase positiva10.

A adulteração e fraude em produtos alimentícios são muito comuns. Essas modificações/adulterações podem facilitar o desenvolvimento de microrganismos tanto comuns à flora natural do homem quanto aos microrganismos patogênicos.

As boas práticas de fabricação (BPF) fazem parte do sistema de controle de qualidade e são definidas como "os procedimentos necessários para garantir a qualidade sanitária dos alimentos", que envolvem todo o processo de produção, desde a recepção de matérias-primas, as condições higiênico-sanitárias dos estabelecimentos, os requisitos de higiene do estabelecimento, higiene pessoal e requisito sanitário onde, todas as pessoas que manipulem alimentos devem receber instrução adequada e contínua em matéria higiênica-sanitária, na manipulação dos alimentos e higiene pessoal, e higiene na produção12, até a saída 
do produto acabado da indústria. Deve-se garantir que o alimento chegue até a casa do consumidor com boas qualidades e condições de uso.

Os consumidores devem estar sempre atentos quanto a qualidade dos alimentos consumidos, como prevenção a saúde. Essas contaminações microbianas dos alimentos, em específico do queijo parmesão ralado, tem importante relevância no aspecto econômico das indústrias, e na saúde pública por serem possíveis transmissores de doenças.

Neste sentido, este trabalho tem como objetivo avaliar os microrganismos indicadores higiênico-sanitário e detectar presença ou ausência de Salmonella em amostras de queijos parmesão ralado disponíveis no comércio da cidade de Campos dos Goytacazes - RJ.

\section{MATERIAL E MÉTODO}

O estudo realizado classifica-se como pesquisa observacional transversal, para análise dos parâmetros microbiológicos de queijo ralados processados comercializados na cidade de Campos dos Goytacazes, RJ, além de uma pesquisa bibliográfica na base de dados das Revistas do SEER do IBICT.

A pesquisa observacional transversal foi feita com queijos parmesão ralados que estavam dentro do prazo de validade, armazenados nas condições especificadas pelo fabricante e com a embalagem íntegra. Foram utilizadas cinco marcas e/ou fabricantes diferentes de queijo ralados processados, comercializados em Campos dos Goytacazes - RJ, sendo adquiridas três amostras de cada marca, totalizando 15 amostras.

As análises microbiológicas realizadas de acordo com a RDC no. 12, de 2 de janeiro de 2001, para contagem de Coliformes Totais e Termotolerantes $\left(45^{\circ} \mathrm{C}\right)$ e pesquisa de Salmonella sp. Além dessas recomendações foi feito uso do Manual de Métodos de Análise Microbiológica de Alimentos e Água. Os dados obtidos foram registrados em um protocolo de pesquisa.

Para a realização desta pesquisa foi solicitada a autorização do Diretor da Faculdade de Medicina de Campos onde ocorreu o estudo.

As amostras, oriundas de lotes de fabricação diferentes, foram adquiridas no segundo semestre de 2015 e transportadas em suas embalagens originais para o Laboratório Annelise Wilken da Faculdade de Medicina de Campos.

No laboratório, as amostras foram codificadas e higienizadas, antes de sua abertura para análise.

A homogeneização das amostras foi realizada na própria embalagem e, após a abertura das mesmas, foi retirada assepticamente $25 \mathrm{~g}$ da amostra e transferida para frascos de diluição contendo $225 \mathrm{~mL}$ de água salina peptonada autoclavada. A partir dessa solução procedeu-se as diluições subsequentes necessárias à análise microbiológica do produto. As análises foram realizadas em triplicata.

A contagem de coliformes totais efetuada pelo "método do número mais provável (NMP)" no qual alíquotas de $1 \mathrm{~mL}$ de cada diluição foram transferidas para tubos contendo $10 \mathrm{~mL}$ de caldo lauril sulfato triptose (LST) (35.5g.L-1) e incubadas em estufa durante $24 \mathrm{~h}$, a $35^{\circ} \mathrm{C}$, para observação do crescimento microbiano com produção de gás. Em caso positivo, uma alçada carregada dos tubos LST foi transferida para o caldo verde brilhante bile (VB) (40g.L-1) para contagem dos coliformes totais. Os tubos de caldo VB foram incubados durante $24-48 \mathrm{~h}$ a $35^{\circ} \mathrm{C}$ para se observar o crescimento e a produção de gás. 0 número de tubos VB positivos para crescimento e ocorrência de gás foi registrado para determinação do NMP/g através da tabela disponível no Manual de Métodos de Análise Microbiológica de Alimentos e Água. Uma outra alçada dos tubos LST positivos foi transferida para tubos contendo o caldo E. coli (EC) (37g.L-1) para determinação dos coliformes totais. Os tubos com caldo EC foram incubados em banho-maria a $45.5^{\circ} \mathrm{C}$ durante 24h. Após este tempo foi analisado o crescimento e a produção de gás. 0 número de tubos positivos foi anotado e o NMP/g obtido comparado com os dados do Manual de Métodos de Análise Microbiológica de Alimentos e Água.

Conforme determina a legislação, a pesquisa de Salmonella sp. foi feita de forma qualitativa, sendo o resultado expresso como presença ou ausência do microrganismo em 25g de alimento. Segundo a legislação vigente, a presença desse microrganismo em $25 \mathrm{~g}$ de alimento torna o produto impróprio para consumo humano.

Foram homogeneizados $25 \mathrm{~g}$ de cada amostra e $225 \mathrm{~mL}$ de Caldo Lactosado e incubados a $35^{\circ} \mathrm{C}$ em estufa bacteriológica durante 20 horas. Após este período, $1 \mathrm{~mL}$ dessa suspensão foi transferida para $10 \mathrm{~mL}$ de caldo Selenito-Cistina (SC) e $10 \mathrm{~mL}$ de Caldo Tetrationato (TT), e incubados a $35^{\circ} \mathrm{C}$ em estufa 
bacteriológica por 24 horas. Posteriormente, os tubos foram agitados e foi estriada uma alçada do caldo TT em placas de Petri contendo Agar Entérico de Hectoen (HE), Agar Bismuto Sulfito (BS) e Agar Xilose Lisina Desoxiciolato (XLD). As placas foram incubadas invertidas a $35^{\circ} \mathrm{C}$ por 24 horas e verificou-se se houve o desenvolvimento de colônias típicas de Salmonella. Esse procedimento também foi realizado com os tubos contendo caldo SC.

A interpretação dos resultados ocorreu de acordo com os critérios microbiológicos estabelecidos na legislação brasileira, regida pela RDC $N^{\circ}$ 12, 02 de janeiro de 2001 da Agência Nacional de Vigilância Sanitária (ANVISA).

\section{RESULTADOS E DISCUSSÃO}

Os resultados das análises microbiológicas realizadas nas amostras de queijos parmesão ralados estão apresentados a seguir, na Tabela 1.

Tabela 1 - Resultados das análises microbiológicas realizadas nas amostras de queijo parmesão ralado

\begin{tabular}{|c|c|c|c|}
\hline \multirow{2}{*}{ Amostras } & \multicolumn{1}{c}{$\begin{array}{c}\text { Coliformes } \\
\text { Totais }\end{array}$} & $\begin{array}{c}\text { Coliformes } \\
\text { Termotolerantes }\end{array}$ & Salmonella sp \\
\hline A1 & $<3 \mathrm{NMP} / \mathrm{g}$ & $<3 \mathrm{NMP} / \mathrm{g}$ & AUSÊNCIA \\
\hline $\mathrm{A} 2$ & $<3 \mathrm{NMP} / \mathrm{g}$ & $<3 \mathrm{NMP} / \mathrm{g}$ & AUSÊNCIA \\
\hline $\mathrm{A} 3$ & $<3 \mathrm{NMP} / \mathrm{g}$ & $<3 \mathrm{NMP} / \mathrm{g}$ & AUSÊNCIA \\
\hline B1 & $<3 \mathrm{NMP} / \mathrm{g}$ & $<3 \mathrm{NMP} / \mathrm{g}$ & AUSÊNCIA \\
\hline B2 & $<3 \mathrm{NMP} / \mathrm{g}$ & $<3 \mathrm{NMP} / \mathrm{g}$ & AUSÊNCIA \\
\hline B3 & $<3 \mathrm{NMP} / \mathrm{g}$ & $<3 \mathrm{NMP} / \mathrm{g}$ & AUSÊNCIA \\
\hline C1 & $<3 \mathrm{NMP} / \mathrm{g}$ & $<3 \mathrm{NMP} / \mathrm{g}$ & AUSÊNCIA \\
\hline C2 & $<3 \mathrm{NMP} / \mathrm{g}$ & $<3 \mathrm{NMP} / \mathrm{g}$ & AUSÊNCIA \\
\hline C3 & $<3 \mathrm{NMP} / \mathrm{g}$ & $<3 \mathrm{NMP} / \mathrm{g}$ & AUSÊNCIA \\
\hline D1 & $3 \mathrm{NMP} / \mathrm{g}$ & $3 \mathrm{NMP} / \mathrm{g}$ & AUSÊNCIA \\
\hline D2 & $3 \mathrm{NMP} / \mathrm{g}$ & $3 \mathrm{NMP} / \mathrm{g}$ & AUSÊNCIA \\
\hline D3 & $3 \mathrm{NMP} / \mathrm{g}$ & $3 \mathrm{NMP} / \mathrm{g}$ & AUSÊNCIA \\
\hline E1 & $<3 \mathrm{NMP} / \mathrm{g}$ & $<3 \mathrm{NMP} / \mathrm{g}$ & AUSÊNCIA \\
\hline E2 & $<3 \mathrm{NMP} / \mathrm{g}$ & $<3 \mathrm{NMP} / \mathrm{g}$ & AUSÊNCIA \\
\hline E3 & $<3 \mathrm{NMP} / \mathrm{g}$ & $<3 \mathrm{NMP} / \mathrm{g}$ & AUSÊNCIA \\
\hline
\end{tabular}

*Número mais provável (NMP)

Não houve crescimento de Salmonella sp. em nenhuma das amostras analisadas e, três amostras (20\%), todas de uma mesma marca, apresentaram contagem para coliformes totais e termotolerantes (3 NMP/g), mas com valores dentro dos limites estabelecidos pela RDC $N^{\circ} 12,02$ de janeiro de 2001 da Agência Nacional de Vigilância Sanitária (ANVISA).

Existem fatores e condições que podem favorecer o desenvolvimento de microrganismos deteriorantes e/ou patogênicos, desde a sua saída da indústria até o seu consumo interferindo assim, na qualidade do produto final.

Os alimentos são os principais veículos de transmissão da Salmonella sp, especialmente leite e vegetais crus, mariscos e ovos. Semelhante aos trabalhos de Ribeiro (2012), Trombete (2012) e Nunes (2015), as amostras não apresentaram contaminação por Salmonella sp, estando assim dentro do parâmetro estabelecido pela legislação, onde o produto é considerado inutilizável com a presença de uma única bactéria. 
A Salmonella sp é uma bactéria que apresenta incidência discreta no leite visto que é necessário que o rebanho esteja doente ou que o manipulador seja portador20, isso pode explicar a sua baixa incidência nos derivados do leite.

No trabalho de Trombete (2012), onde foram avaliados outros microrganismos patogênicos e também aspectos químicos, duas amostras foram positivas para coliformes totais e termotolerantes com valores ainda abaixo do limite máximo permitido pela legislação.

Diferentemente, Pimentel (2002) não observou em seu trabalho positividades para coliformes totais e termotolerantes, correlacionando então com os baixos teores de umidade, baixa atividade água e com a presença de conservadores nas amostras.

No trabalho de Salvador (2001) todas as amostras de queijo parmesão ralado apresentaram NMP de coliformes fecais (g) iguais a $<3$, e duas amostras apresentaram NMP de coliformes totais (g) acima de 3.

Os cuidados com a matéria prima e com as boas práticas de fabricação são importantes já que a presença de coliformes é indicativa de exposição à condição higiênica inadequada.

Aspectos físico-químicos como umidade, atividade água, acidez, pH, conservantes, entre outros podem influenciar na qualidade microbiológica do produto final. A má qualidade microbiológica pode apresentar além de riscos à saúde do consumidor, prejuízos econômicos11.

As amostras analisadas por Nunes (2015) apresentaram teor médio de cloreto de sódio ( $\mathrm{NaCl}$ ) maior do que o informado no rótulo das embalagens, e esse atua diminuindo a atividade água a valores fora da faixa ideal de crescimento de muitos microrganismos, entre eles os coliformes. Vale então, reafirmar que as duas características que os queijos parmesão apresentam, maior quantidade de $\mathrm{NaCl}$ e menor atividade água, são fatores que atuam na conservação aumentando assim a vida útil do produto.

\section{CONCLUSÃO}

A amostra analisada de queijo parmesão ralado para Salmonella sp. não apresentou crescimento. Três amostras de uma mesma marca apresentaram contagem para coliformes totais e termotolerantes dentro dos limites estabelecidos pela legislação vigente. Desse modo é necessário considerar a importância de um maior cuidado no processo de fabricação de queijos tipo parmesão ralado, pois os resultados sugerem falhas nesse processo. A fiscalização por parte das entidades competentes é uma medida que contribui para o cumprimento da legislação garantindo a qualidade do produto para o consumidor.

Recomenda-se um estudo com maior número de amostras e análise de outros microrganismos que avaliem as condições higiênico-sanitárias além dos aspectos físico-químicos.

\section{REFERÊNCIAS}

[1] JUSTUS, A. et al. Caracterização física e química de queijos parmesão ralado comercializados na Região Sul de Minas Gerais. Revista do Instituto de Laticínios Cândido Tostes, Juiz de Fora, v.66, n.379, p. 16-24, mar./abr. 2011.

[2] BALBANI, A. P. S.; BUTUGAN, O. Contaminação biológica de alimentos. Pediatria, v.23, n.4, p. 320-328, 2001.

[3] BRASIL. Ministério da Agricultura, Pecuária e Abastecimento. Regulamento Técnico de Identidade e Qualidade de Queijo Parmesão. Portaria 353 de 4 de setembro de 1997. Diário Oficial da República Federativa do Brasil, 08 set. 1997a. Seção 1, p. 19684.

[4] BRASIL. Ministério da Agricultura, Pecuária e Abastecimento. Regulamento Técnico para Fixação de Identidade e Qualidade de Queijo Ralado. Portaria 357 de 4 de setembro de 1997. Diário Oficial da República Federativa do Brasil, 08 set. 1997b. Seção 1, p. 19688.

[5] TROMBETE, F. M. et al. Avaliação da qualidade química e microbiológica de queijo parmesão ralado comercializado no Rio de Janeiro. Revista do Instituto de Laticínios Cândido Tostes, Juiz de Fora, v.67, n.385, p.11-16, mar./abr. 2012.

[6] BARROS, J. J. C. et al. Queijo Parmesão: caracterização físico-química, microbiológica e microestrutura. Ciênc. Tecnol. Aliment., Campinas, v.31, n.2, Junho 2011.

[7] PERRY, K. S. P. Queijos: Aspectos químicos, bioquímicos e microbiológicos. Química Nova, São Paulo, v.27, n.2, p.293-300, 2004.

[8] SILVA, N. et al. Manual de métodos de análise microbiológica de alimentos e água, 4. ed. São Paulo: Varela; 2010 . 
[9] AGUILAR, C. E. G. Queijos tipo parmesão ralados industrialmente e no ato da venda, adquiridos no comércio varejista, como fontes de agentes deteriorantes e patogênicos. Dissertação (mestrado) - Universidade Estadual Paulista, Faculdade de Ciências Agrárias e Veterinárias, Jaboticabal, 2014. iv, 62 p.

[10] BRASIL. Ministério da Saúde. Regulamento Técnico sobre os Padrões Microbiológicos para Alimentos. Resolução RDC ANVISA/MS no 12, de 02 de janeiro de 2001. Diário Oficial da República Federativa do Brasil, 10 jan. 2001. Seção 1, p. 45.

[11] SALVADOR, M. et al. Avaliação da qualidade microbiológica de queijo prato e parmesão ralado. Boletim do Centro de Pesquisa e Processamento de Alimentos, Curitiba, v.19, n.1, p.65-74, jan./jun. 2001.

[12] BRASIL. Ministério da Saúde. Regulamento Técnico sobre as Condições Higiênico-Sanitárias e de Boas Práticas de Fabricação para Estabelecimentos Produtores/Industrializadores de Alimentos. Portaria n ${ }^{\circ} 326$, de 30 de julho de 1997. Diário Oficial da República Federativa do Brasil, 08 ago. 1997c. Seção 1, p. 16560.

[13] BRASIL. Ministério da Agricultura, Pecuária e Abastecimento. Regulamento Técnico de Identidade e Qualidade de Queijos. Portaria 146 de 7 de março de 1996. Diário Oficial da República Federativa do Brasil, 11 mar. 1996. Seção 1, p. 3977.

[14] RIBEIRO, J. C. B. et al. Qualidade físico-química e microbiológica do queijo parmesão ralado comercializado em Ponta Grossa, Paraná. Revista do Instituto de Laticínios Cândido Tostes, Juiz de Fora, v.67, n.387, p.21-29, jul./ago. 2012.

[15] NUNES, A. C. M. et al. Qualidade físico-química e microbiológica de queijos ralados comercializados em Recife -PE, Brasil. Journal of Bioenergy and Food Science, Macapá, v.2, n.1, p.25-31 jan./mar. 2015.

[16] OLIVEIRA, L. M. A. et al. Avaliação da qualidade de queijos ralados para proteção à saúde pública. Revista do Instituto de Laticínios Cândido Tostes, Juiz de Fora, v.67, n.384, p.41-47, jan./fev. 2012.

[17] PIMENTEL, E. F. et al. Avaliação da rotulagem e da qualidade físico-química e microbiológica de queijo ralado. Ciência e Tecnologia de Alimentos, Campinas, v.22, n.3, p. 289-294, set./dez. 2002.

[18] VELOSO, A. C. A. et al. Detecção de adulterações em produtos alimentares contendo leite e/ou proteínas lácteas. Química Nova, São Paulo, v.25, n.4, p. 609-615, 2002.

[19] SANTOS, V. A. Q.; HOFFMANN, F. L. Avaliação das boas práticas de fabricação em linha de processamento de queijos Minas frescal e ricota. Rev. Inst. Adolfo Lutz, São Paulo, 69(2), p. 222-228, abr./jun. 2010.

[20] SHINOHARA, N. K. S. et al. Salmonella spp., importante agente patogênico veiculado em alimentos. Ciência \& Saúde Coletiva, Rio de Janeiro, v.13, n.5, p. 1669-1674, set./out. 2008. 


\section{Capítulo 13}

\section{Estudo da hidrólise ácida e enzimática da borra de café como alternativa de uso deste resíduo}

\section{Diego Sorge de Angeli \\ Isabel Craveiro Moreira Andrei \\ Aneli de Melo Barbosa Dekker \\ Claudio Takeo Ueno \\ Lucia Felicidade Dias}

Resumo: A indústria de café solúvel produz uma grande quantidade de borra de café, com potencial para diversas aplicações. 0 objetivo deste trabalho foi verificar a eficácia da hidrolise ácida $(\mathrm{HCl})$ e enzimática (Viscozyme L) da borra de café. A hidrolise ácida foi realizada em diferentes condições de temperatura e pressão utilizando-se banhomaria e autoclave. A otimização dos parâmetros da hidrólise enzimática ( $\mathrm{pH}$, tempo e temperatura) foram determinadas através do delineamento composto central rotacional (DCCR) utilizando-se como substrato da enzima papel Whatman no1. As melhores condições obtidas para hidrolise da celulose do papel de filtro foram pH 4,0 à 45으/hora, equivalente a 50 FBG (Fungal $\beta$-glucanase) porém a borra de café hidrolisada enzimaticamente nessas condições, não apresentou resultados satisfatórios. Assim, optou-se pela combinação da hidrolise enzimática seguida da hidrólise ácida utilizando ácido clorídrico (120 ำ/ 2 h), obtendo-se um valor expressivo de glicose quando comparado a hidrolise ácida.

Palavras-chave: Resíduo lignocelulósico, Viscozyme L, Planejamento experimental. 


\section{INTRODUÇÃO}

A industrialização limpa é um tema muito discutido atualmente, cujo principal objetivo é a minimização da geração de resíduos e concomitantemente, a aplicação em recursos renováveis. A Química Verde é uma área da química que vem crescendo, tendo como foco do estudo o reaproveitamento dos resíduos industriais, proporcionando maior valor agregado e, ao mesmo tempo incentivando o uso dos mesmos como matéria-prima em outros processos industriais, desde a produção de alimentos até de medicamentos (Ferreira et al, 2013).

0 café é uma das bebidas mais consumidas mundialmente. Com a praticidade de preparo e a melhora na qualidade do café solúvel, o consumo deste produto tem aumentado; somente no Brasil foram produzidas 60 mil toneladas de café solúvel em 2014. A produção de café solúvel segundo Viotto (1991) ocorre em várias etapas: primeiro a limpeza dos grãos através da retirada de impurezas, a torrefação dos grãos onde se determina o grau e a cor, a moagem ou granulação onde os grãos são triturados aumentando a superfície de contato e o rendimento da extração e em seguida a extração.

0 processo de extração utiliza água à temperatura de $180{ }^{\circ} \mathrm{C}$ removendo as substancias solúveis do café. Após esta etapa, o extrato segue para a clarificação e depois passa por um processo de concentração e secagem por pulverização (spray drying) ou liofilização (freeze drying). A borra é o resíduo sólido obtido após a etapa de extração. Em média para cada tonelada de café verde obtêm-se $480 \mathrm{~kg}$ de borra, a qual é utilizada para gerar energia nas caldeiras da indústria de café solúvel (Adam e Dougan, 1985). Logo, devido a quantidade de borra de café gerada há uma necessidade de destinação adequada.

Uma alternativa de utilização da borra de café é a hidrólise ácida originando produtos fermentáveis para obtenção de bicombustíveis. Mussatto e cols. (2010) hidrolisaram a borra de café utilizando ácido sulfúrico em diferentes concentrações e relataram que os produtos obtidos são constituídos em sua maioria por carboidratos (manose, galactose e arabinose). Outra opção é a utilização de catálise enzimática, visando a hidrólise da celulose, a qual tem sido mais estudada atualmente, oferecendo boa conversão com custos menores, porém são poucos os processos em fase comercial devido aos custos e eficiência (Castro e Pereira, 2010).

0 desenvolvimento de processos enzimáticos de hidrólise que sejam viáveis economicamente está relacionado com a abundância de material celulósico na natureza, custos de produção e a destinação dos açúcares resultantes poderão ser utilizados para a produção de etanol, mas também para a obtenção de uma grande variedade de produtos químicos (Rossel e Soares, 2009).

\section{MATERIAIS E MÉTODOS}

\subsection{BORRA DE CAFÉ}

A borra de café estudada foi proveniente de café torrado 100\% arábica após a extração industrial de sólidos solúveis para a produção de café solúvel.

A amostra de borra foi coletada após a prensagem foi seca em estufa a $65^{\circ} \mathrm{c}$ por 48 horas e gentilmente cedida pela Cia. Cacique de Café Solúvel de Londrina - PR.

\section{MÉTODOS}

Hidrólise ácida da borra de café com ácido clorídrico diluído em autoclave e em banho maria: A hidrólise ácida foi realizada em frascos Erlenmeyer de $250 \mathrm{~mL}$, contendo 0,3 $\pm 0,001 \mathrm{~g}$ de amostra em base seca e 10 $\mathrm{mL}$ ácido clorídrico $0,6 \mathrm{M}$. Em seguida, o frasco contendo a borra e ácido foi submetido a autoclavagem (120min./121 ํㅡ, à pressão de $1 \mathrm{Kgf}$ ). Após esse processo, a amostra foi resfriada até temperatura ambiente, filtrada em fibra de vidro e transferida para um balão volumétrico de $100 \mathrm{~mL}$ e completando-se o volume com água ultrapura Milli-Q (Millipore, MA, EUA) e homogeneizada.

A solução obtida acima foi filtrada novamente em membrana de 0,22 $\mu$ m (GVWP 02500 - Millipore, MA, EUA), e transferida para cartucho Sep-Pak C18 (Waters, Milford, EUA) pré-condicionado com metanol e água para ultra filtração. As primeiras gotas foram descartadas e na sequencia coletou-se a amostra para analise cromatográfica.

A hidrólise em banho-maria foi desenvolvida a $85^{\circ} \mathrm{C}$ por 180 minutos, utilizando igual quantidade de amostra e volume e concentração de ácido descrita anteriormente na hidrólise em autoclave. As etapas de extração e analise seguiram os mesmos protocolos acima descritos. 
Hidrólise enzimática da borra de café com a enzima comercial Viscozyme L®: 0 processo de otimização da hidrólise enzimática foi realizada utilizando-se um planejamento experimental do tipo delineamento composto central rotacional (DCCR). 0 planejamento experimental foi gerado pelo programa Statistica 8.0 sendo os parâmetros selecionados: concentração da enzima Viscozyme L® (10 a 50 FBG), temperatura de incubação da enzima (35 a $\left.55^{\circ} \mathrm{C}\right)$, pH $(3,0$ a 5,0) e o tempo $(0,5$ a 2,5h). Os níveis destas variáveis estudadas estão descritos na Tabela 1.

Tabela 1. Níveis de variáveis independentes

\begin{tabular}{|l|c|c|c|c|c|}
\hline \multicolumn{2}{|c}{ Variáveis Independentes } & \multicolumn{5}{c}{ Níveis } & +1 \\
\hline [Viscozyme L®] (FBG) & 10 & 20 & 30 & 40 & 50 \\
\hline Tempo (horas) & 0,5 & 1 & 1,5 & 2,0 & 2,5 \\
\hline $\mathrm{pH}$ & 3,0 & 3,5 & 4,0 & 4,5 & 5,0 \\
\hline Temperatura $(-2$ & -1 & 45 & 50 & 55 \\
\hline
\end{tabular}

A quantidade de glicose proveniente da hidrolise enzimática, foi calculada segundo o método de sacarificação com celulase proposto por Mendels e cols. (1976) "in vitro", em tubo de ensaio onde foi adicionado a enzima Viscozyme L® conforme descrito na Tabela 1, completando o volume com água até 1 mL quando necessário e adicionado $0,5 \mathrm{~mL}$ de tampão citrato-fosfato. 0 substrato para essa reação foi uma tira de papel de filtro Whatman no 1 de $50 \mathrm{mg}$ (1 x $6 \mathrm{~cm}$ aproximadamente), submersa na solução. As condições de incubação em banho-maria estão especificadas na Tabela 1.

Após o tempo de reação o tubo de ensaio foi mantido em banho de gelo para interrupção da reação enzimática. Após 5 minutos, adicionou-se $3 \mathrm{~mL}$ de solução de DNS e os tubos foram mantidos em banhomaria fervente por 5 minutos para inativação da enzima e logo após foram transferidos para um banho de água fria e interrompida a reação. Em seguida, adicionou-se $16 \mathrm{~mL}$ de água destilada, sendo realizada a leitura em espectrofotômetro a 550nm para determinar a quantidade de glicose, conforme o método de determinação de açúcares redutores descrito Miller e colaboradores (1959).

Uma vez determinadas as condições ótimas da hidrólise enzimática da borra de café com a Viscozyme L®, uma nova amostra de borra $(0,3000 \pm 0,001 \mathrm{~g})$ foi hidrolisada nos parâmetros definidos pelo DDCR. Outra amostra de borra $(0,3000 \pm 0,001 \mathrm{~g})$ foi submetida a uma nova hidrólise conforme descrita anteriormente com a enzima Viscozyme $\mathrm{L} \circledast$ e posteriormente adicionado $10 \mathrm{~mL}$ de ácido clorídrico 0,6M (hidrolise combinada) e mantida em autoclave conforme descritos anteriormente e em seguida retiradas devidamente as amostrar para análise cromatográfica para análise do perfil de carboidratos.

Sistema cromatográfico e condições analíticas utilizadas para a detecção de carboidratos: 0 sistema cromatográfico utilizado consistiu de bomba inerte de alta pressão (LC-10Ai - Shimadzu); válvula solenoide de baixa pressão de 3 vias (NResearch-1367-1372); Circuitos externos "Lab-made"; controladores de válvulas e célula; válvula de alta pressão de 10 vias (VICI-C2-2340 EP); Forno Waters com controlador (CHX 650 -Pickering); fonte de \pm 12 V (RS570-Stanford); célula eletroquímica Au (ED-50Dionex); interface e potenciostato Autolab (PGSTAT 30- Eco Chemie); Computador Pentium D com software (GPES - Eco Chemie V.4.9).

Para a execução dos experimentos foram utilizados pré-coluna e coluna CarboPac PA1 (4,0 x 250 mm, Dionex, Sunnyvale, EUA) a 28oC; sistema em modo isocrático com fases: $\mathrm{NaOH} \mathrm{1,4} \mathrm{mmol} \mathrm{L-1} \mathrm{(como}$ eluente: 0-45 min e como fase de reequilíbrio: 57,6-72,6 min) e $\mathrm{NaOH} 300,0 \mathrm{mmol} \mathrm{L-1}$ (para a regeneração: 45,1-57,5 min). 0 fluxo foi de 1,0 mL min-1; com volume de injeção de 20,0 $\mu \mathrm{L}$; forma de onda de pulso em amperimetro ED-50-Au: 0,20 V (400 ms); 0,65 V (200 ms) e -0,20 V (400 ms). 0 tratamento de dados foi feito com software INTEGRA. 


\section{RESULTADOS E DISCUSSÕES}

\subsection{HIDRÓLISE ENZIMÁTICA}

Planejamento experimental DCCR: Os gráficos de superfície de resposta obtidos a partir dos dados do planejamento DCCR estão apresentados a seguir na Figura1.

Figura 1 - Gráficos de superfície de resposta, (a) glucose obtida em função do tempo de reação da hidrólise do papel Whatman no 1 e concentração da enzima Viscozyme L®; (b) glucose obtida em função do pH da solução tampão utilizada e o tempo de hidrólise do papel Whatman no 1; (c) glucose obtida em função da temperatura e tempo de hidrólise do papel Whatman $\mathrm{n}$ 1 .

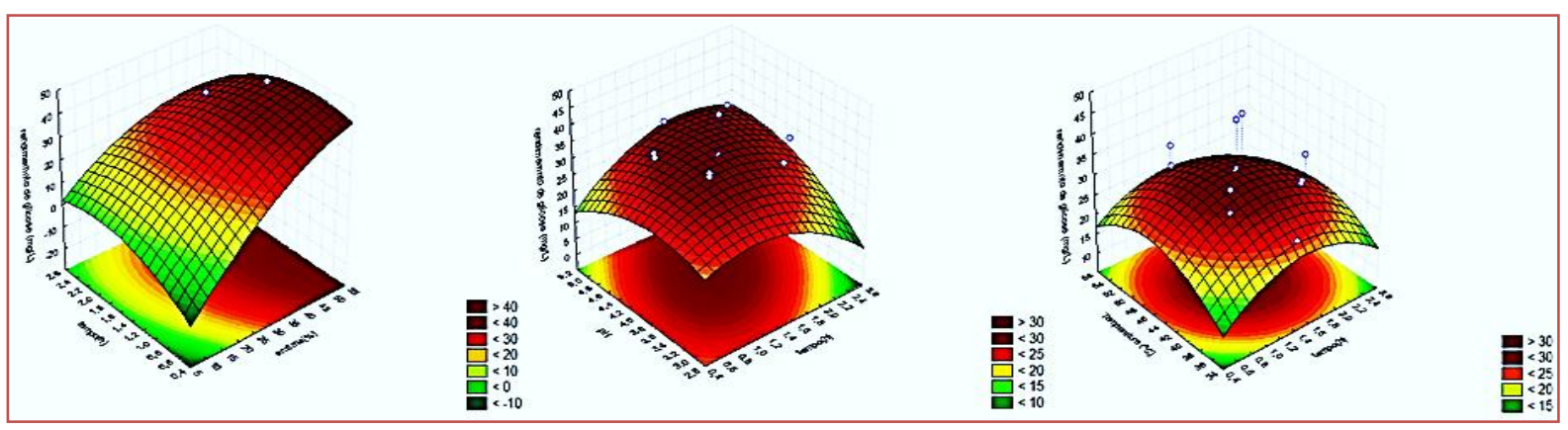

A partir dos dados obtidos do DDCR foi deduzida a equação de regressão para o rendimento em glucose (R) descrita a seguir:

$R=-130,558+1,947 \mathrm{E}-0,013 \mathrm{E} 2+15,218 \mathrm{t}-7,369 \mathrm{t} 2+3,11 \mathrm{p}-4,363 \mathrm{p} 2+4,428 \mathrm{~T}-0,071 \mathrm{~T} 2-0,269 \mathrm{E} . \mathrm{t}+$ 0,031E.p - 0,002E.T + 5,135 t.p - 0,138t.T + 0,564p.

Onde: R corresponde ao rendimento em glucose, E a concentração de enzima, t o tempo de reação, p o pH da solução tampão T a temperatura utilizada.

Após a análise dos resultados do DDCR pelo programa Statistica 8.0 foi possível determinar as condições ótimas de hidrolise da celulose do papel Whatman n⿳0 1 em função da concentração de glucose proveniente da hidrólise enzimática: 50 FBG de Viscozyme L® em pH 4,0 por 1 hora de reação à $45 \stackrel{\circ}{\circ}$ C. Nestas condições, o valor preditivo da quantidade de glicose da hidrólise enzimática do papel Whatman no 1 foi de 44,35 mgL-1.

A hidrólise experimental realizada nas condições acima descritas, para validar o valor preditivo foi obtive o seguinte resultado: $42,04+1,43 \mathrm{mgL}-1$ de glucose, o qual esta dentro da faixa preditiva do valor calculado pela equação. A borra de café também foi submetida a hidrolise com a Viscozyme L® nas condições otimizadas pelo DCCR acima descritas, porém a enzima não hidrolisou a borra.

\subsection{ANÁLISE COMPARATIVA ENTRE AS HIDRÓLISES}

A Tabela 2 apresenta os resultados das análises de carboidratos obtidos das hidrólises ácida em autoclave (AA), ácida em Banho Maria (ABM) e combinada: enzimática e ácida em autoclave (E + $\mathrm{AA})$ da borra de café.

Tabela 2. Comparação dos carboidratos resultantes das hidrólises ácida em autoclave, banho-maria e ácidas, e combinadas: enzimática e ácida em autoclave da borra de café.

\begin{tabular}{|c|c|c|c|c|c|c|c|}
\hline & \multicolumn{7}{|c|}{ Carboidratos (\%) } \\
\hline & Manitol & Arabinose & Galactose & Glucose & Xilose & Manose & Frutose \\
\hline $\mathrm{AA}^{* *}$ & N.D.* & N.D.* & $0,37+0,12$ & $2,06+0,15$ & N.D.* & $12,16+0,39$ & N.D.* \\
\hline $\mathrm{ABM}^{* * *}$ & N.D.* & N.D.* & $0,41+0,01$ & $0,24+0,01$ & N.D.* & $3,42+0,015$ & N.D.* \\
\hline $\mathrm{E}+\mathrm{AA}^{* * * *}$ & N.D.* & N.D.* & $0,84+0,27$ & $35,8+21,22$ & N.D.* & $9,31+16,05$ & N.D.* \\
\hline
\end{tabular}

*Não Detectado, **Ácida em Autoclave, ***Ácida em Banho Maria, ${ }^{* * * * C o m b i n a d a: ~ e n z i m a ́ t i c a ~ e m ~ e ~ a ~ a ́ c i d a ~ e m ~}$ autoclave. 
A quantidade de glucose gerada sob as diferentes condições de hidrolise demonstrou que a combinação da hidrolise ácida, seguida da hidrolise enzimática é mais eficiente e, observando-se os valores obtidos com a hidrolise a altas temperaturas (autoclave) pode-se observar o efeito do calor.

A baixa hidrolise em baixas temperaturas é devido a própria resistência desses polímeros à hidrolise, entretanto cabe ressaltar que em altas temperaturas é possível ocorrer a conversão da glucose em ácido fórmico (Yoon, et al 2014).

\section{CONCLUSÕES}

A hidrólise ácida em autoclave foi mais eficiente do que a realizada em banho-maria, visto que há uma maior quantidade de monossacarídeos no hidrolisado.

Os resultados do planejamento DCCR demonstraram que as condições ótimas de hidrólise da celulose do papel Whatman no 1 utilizando-se a Viscozyme L® foram: 50 FBG de Viscozyme L® em pH 4,0 por 1 hora de reação à $45^{\circ} \mathrm{C}$. 0 valor preditivo nestas condições, em glucose foi $43,18 \mathrm{mgL}-1$, enquanto que o resultado experimental obtido foi $42,04+1,43 \mathrm{mgL}-1$ de glucose, o que esta em concordância com o modelo utilizado.

A hidrólise enzimática da borra de café quando empregou-se apenas a Viscozyme L® para a obtenção de monossacarídeos, não foi eficiente, provavelmente devido a inativação da enzima por compostos oriundos da torra do café ainda presentes na borra.

A combinação das hidrólises enzimática e ácida em autoclave da borra de café foi mais eficaz, sugerindo a possibilidade de aplicar esse processo em escalas maiores, entretanto é importante salientar o custo da enzima.

A hidrólise ácida prévia da borra do café pode ser um processo interessante visto que facilita o processo de hidrolise enzimática seguinte. Tal informação é promissora, pois assim será possível estudar a hidrólise enzimática da borra do café por micro-organismos produtores de celulases e ligninases combinada com hidrolises ácidas prévias.

\section{REFERÊNCIAS}

[1] Adam, M. R.; Dougan, J. (1985) Waste Products, Coffee, VII - Technology, ed. R. J. Clarke and R Macrae, Elsevier Applied Science Publishers, London, pp. 291.

[2] Castro, Aline Machado; Pereira, Nei Jr (2010) Produção, propriedades e aplicação de celulases na hidrólise de resíduos agroindustriais. Química Nova, 33(1) , 181-188.

[3] Ferreira, V. F.; Da Rocha, D. R.; Da Silva, F. C. (2013); Química Verde, Economia Sustentável e Qualidade de Vida. Data de publicação na Web: 12 de outubro de 2013. Rev. Virtual Quim., Disponível em: http://rvq.sbq.org.br/index.php/rvq.

[4] Mandels, M.; Andreotti, R.; Roche, C (1976). Measurement of saccharifying celulase Biotechnol. Bioeng. 6., 2133.

[5] Miller, G. L.(1959). Use of dinitrosalicylic acid reagent for determination of reducing sugar Analytical Chemistry, Washington, US, 31(3) 426-428.

[6] Mussato, Solange I. ;Carneiro, Livia M.,Silva, João P.A.;Roberto, Inês C.;Teixeira, José A. (2010). A study on chemical constituents and sugars extraction from spent coffee grounds; Carbohyd. Polym.,São Paulo - SP; 83, 368374.

[7] Rossell, C. E.,\& Soares, P. A. (2009). Conversão da Celulose pela Tecnologia Organosolv (Vol. 3). São Paulo: Naippe.

[8] Viotto, Luiz. A.(1991). Projeto e Avaliação econômica de sistemas de Secagem de Borra de Café (Dissertação de Mestrado). Campinas: UNICAMP.

[9] Yoon, S.Y., Han S.H., Shin S. J. (2014) The effect of hemicelluloses and lignin on acid hydrolysis of cellulose. Energy (77) 19-24. 


\section{Capítulo 14}

Avaliação de atividade antioxidante e do teor de Estireno em fermentados de diferentes clones de cajueiros por cepas comerciais de saccharomyces cerevisiae

\section{Juliana Cordeiro da Silva \\ Ivanilton Almeida Nery}

Resumo: Uma característica sensorial desagradável em bebidas fermentadas de caju, cuja identificação descritiva sensorial é de "plástico", pode ser associada a presença de estireno. Observa-se um efeito funcional protetor, exercido por sucos e fermentados de frutas, contra o stress oxidativo, que tem sido atribuído à presença de fitoquímicos com ação antioxidante. 0 objetivo do trabalho foi avaliar o perfil antioxidante e o teor de estireno da bebida fermentada de caju oriundos dos cultivares CPP 1001, CPP 76, BRS 189 e EMBRAPA 51 a partir da levedura cervejeira comercial da espécie Saccharomyces cerevisiae US5 da marca FERMENTIS. Verificou-se variação entre os valores da atividade antioxidante entre os fermentados, observando-se maior atividade antioxidante no fermentado EMBRAPA 51. As análises físico-químicas mostraram que seus valores estão de acordo com a legislação brasileira, e o teor de estireno de todos os fermentados está abaixo do limite mínimo de periculosidade toxicológica.

Palavras-chave: atividade antioxidante; estireno; fermentado de caju; DPPH; TPTZ. 


\section{INTRODUÇÃO}

O homem vem se utilizando da fermentação alcoólica, desde a mais remota antiguidade; há mais de 4000 anos os egípcios fabricavam pão e produziam bebidas alcoólicas a partir de cerais e frutas. Entretanto, apenas recentemente é que se pôde relacionar a fermentação com a levedura, fungo amplamente distribuído na natureza e com capacidade de sobrevivência tanto em condições aeróbias como anaeróbias (AQUARONE, 2001).

A fermentação alcoólica de suco de frutas produz álcool etílico como produto principal, e muitos outros componentes secundários, como aldeídos, metanol, álcoois superiores, ácidos e ésteres que contribuem para a qualidade organoléptica do fermentado. (DATO et al., 2005).

A utilização do pedúnculo de caju, para produção de fermentado (vinho), vinagre e destilado do fermentado (aguardente), pode ser uma sugestão de aproveitamento da parte suculenta do fruto, evitando seu grande desperdício (em torno de 85\% da produção anual de mais de 1 milhão de toneladas), e fazendo com que a cultura do caju seja mais valorizada. (TORRES NETO et. al., 2006).

O pedúnculo de caju, por ser rico em açúcares e fitonutrientes, que combatem o estresse oxidativo, é bastante favorável à fermentação. 0 seu uso na elaboração de bebidas alcoólicas remonta há muitos anos, porém o desconhecimento dos parâmetros envolvidos no processo fermentativo do suco tem sido fator limitante para seu aproveitamento na fabricação de vinho, champanhe, vinagre, aguardente, conhaque, entre outros (CASIMIRO, et. al. 2000). São necessários, ainda, alguns estudos que busquem a melhoria do processo fermentativo, visando minimizar as características indesejáveis, para que seja obtido um produto com padrão de qualidade aceitável para vinho de frutas. Um dos principais responsáveis pelo sabor e odor desagradáveis de alguns fermentados de caju é a presença de metabólitos secundários gerados durante o metabolismo das leveduras que, utilizando o pedúnculo do caju como matéria prima, possuiriam o potencial de, dependendo da linhagem, produzir estes metabólitos a partir da descarboxilação de ácidos fenólicos oriundos das transformações bioquímicas no próprio pedúnculo, através da rota metabólica do ácido chiquímico (FLAK \& TSCHEIK, 1997). 0 estireno é uma das substâncias que gera essa característica sensorial negativa e é oriundo da descarboxilação do ácido cinâmico, conforme mostra figura 1.

Figura 1: Descarboxilação do ácido cinâmico originando o estireno.

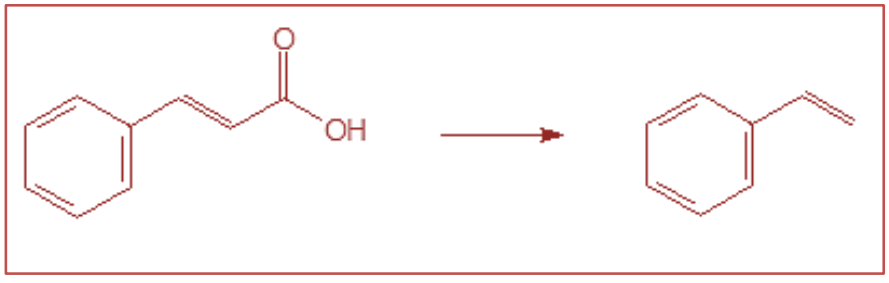

Esses odores frequentemente desagradáveis, cuja identificação descritiva sensorial (dependendo das concentrações dos compostos em questão) vai desde o "suor de cavalo", às especiarias, passando por: plástico, remédio, queimado, etc., o que acarreta enorme perda na qualidade sensorial do fermentado e, consequentemente, a falta de interesse de consumidor.

0 uso de clones resistentes a pragas em relação a árvores frutíferas representa uma forma de manejo econômico, ecológico e seguro, impedindo a invasão de pragas e doenças, além de proporcionar uma melhor utilização da variabilidade genética da espécie, existente tanto na natureza como aquela exteriorizada nas progênies, oriundas de cruzamentos entre plantas de tipos distintos no programa de melhoramento genético. Visando o melhoramento genético de cajueiros, a EMBRAPA Agroindústria tropical produziu vários clones de cajueiros, objetivando a resistência das castanhas em relação a pragas. Os sucos clarificados dos clones utilizados na fermentação (CCP 1001, CCP 76, BRS 189 e EMBRAPA 51) foram cedidos pela EMBRAPA Agroindústria Tropical, localizada em Fortaleza (CE) e o objetivo do trabalho é comparar as características físico-químicas, o teor de estireno e o perfil da atividade antioxidante entre os fermentados dos diferentes clones, a fim de verificar qual fermentado gera uma bebida de maior qualidade. 


\section{MATERIAL E MÉTODOS}

\subsection{PROCESSO FERMENTATIVO}

O mosto foi preparado com o teor de sólidos solúveis a $15^{\circ}$ Brix. Foram utilizados como fermentadores tubos rosqueados estéreis de $70 \mathrm{~mL}$. A levedura comercial liofilizada utilizada foi da marca FERMENTIS US5, da espécie Saccharomyces cerevisiae. Primeiramente realizou-se a inoculação, utilizando 0,2\% p/v de inóculo. Depois da propagação o restante do volume foi adicionado e deixado em condições de temperatura a $25^{\circ} \mathrm{C}$. 0 teor de sólidos solúveis foi verificado em refratômetro com faixa de medição de 0 a $32 \%$ Brix, da marca KASVI. Quando o valor de sólidos solúveis se aproximou de $0^{\circ}$ Brix, o caldo fermentado foi filtrado por membrana millipore com $50 \mathrm{~mm}$ e $0,45 \mu \mathrm{m}$, para remoção da levedura.

\subsection{ATIVIDADE ANTIOXIDANTE PELO REAGENTE DPPH}

A molécula de DPPH (2,2-difenil-1-picril-hidrazil) é caracterizada como um radical livre estável que, quando uma determinada substância que age como doador de átomos de hidrogênio é adicionada a uma solução de DPPH, a hidrazina é obtida com mudança simultânea na coloração de violeta a amarelo pálido.

Utilizou-se o método descrito por Brand-Williams em 1995 para a determinação da atividade antioxidante. A solução de DPPH foi preparada em etanol $(118,29 \mathrm{mg} / \mathrm{L})$ e o fermentado foi diluído em concentrações entre $1 \mu \mathrm{L} / \mathrm{mL}$ e $250 \mu \mathrm{L} / \mathrm{mL}$. Em pequenos tubos de ensaio, 2,5 mL da amostra e $1 \mathrm{~mL}$ de DPPH foram adicionados. Como branco utilizou-se $2,5 \mathrm{~mL}$ da amostra e $1 \mathrm{~mL}$ de etanol. Depois da adição do DPPH, os analitos foram deixados 30 minutos no escuro e em seguida a leitura foi realizada em espectrofotômetro a $518 \mathrm{~nm}$. Os valores são expressos em IC50 (concentração inibitória) que significa a concentração em $\mu \mathrm{g} / \mathrm{mL}$ de antioxidante necessária para reduzir em $50 \%$ o radical. Ou seja, quanto menor o valor de IC50 da amostra, maior seu poder antioxidante frente ao reagente DPPH. As análises foram feitas em triplicata.

\subsection{ATIVIDADE ANTIOXIDANTE PELO MÉTODO FRAP}

0 método FRAP (Ferric Reducing Antioxidant Power) está baseado na redução do Fe3+ em Fe+2. A reação ocorre pela formação de um complexo TPTZ (2,4,6-Tris(2-piridil)-s-triazina) com o Fe (III) de cor amarelada. Na presença de um antioxidante, o ferro presente é reduzido, dando origem ao [Fe(II)(TPTZ)2]3+, de coloração azul escura. (BENZIE \& STRAIN, 1996)

Preparou-se uma solução padrão de sulfato ferroso $2 \mathrm{mM}$. A partir dessa solução, várias soluç̧ões diluídas foram preparadas e utilizadas para determinar a curva-padrão. Tendo a curva-padrão, diluições diferentes dos fermentados foram preparadas, em triplicata. Transferiu-se uma alíquota de $90 \mu \mathrm{L}$ de cada diluição do fermentado para tubos de ensaio, acrescentou-se $270 \mu \mathrm{L}$ de água destilada e misturou-se com $2,7 \mathrm{~mL}$ do reagente FRAP. 0 conteúdo do tubo foi homegeneizado e mantido em banho-maria a $37^{\circ} \mathrm{C}$ no escuro, por 30 minutos. A leitura foi realizada em espectrofotômetro a $595 \mathrm{~nm}$ e o reagente FRAP foi utilizado como branco. 0 potencial antioxidante é medido em $\mu \mathrm{M}$ de $\mathrm{Fe}+2 / \mathrm{L}$ de amostra.

\subsection{AVALIAÇÃO DO TEOR DE ESTIRENO POR CROMATOGRAFIA GASOSA}

A avaliação do teor de estireno se deu por cromatografia gasosa com coluna capilar DB-WAX (polietilenoglicol). A diluição do solvente e da amostra foi feita com acetona. 0 gás de arraste utilizado foi nitrogênio. Dados operacionais: splitless mode a $200^{\circ} \mathrm{C}$; FID a $250^{\circ} \mathrm{C}$; Carreador (Nitrogênio) a $1,5 \mathrm{~mL}$ por minuto; Temperatura do forno: $50^{\circ} \mathrm{C}$ por 8 minutos; 110 a $4^{\circ} \mathrm{C}$ por minuto; 200 a $16^{\circ} \mathrm{C}$ por minuto; Injeção - 2 microlitros.

\subsection{ACIDEZ TOTAL TITULÁVEL E PH}

Determinou-se a acidez total por titulação utilizando o método do Instituto Adolfo Lutz, descrito em 1985. Os fementados foram titulados com solução de hidróxido de sódio $0,01 \mathrm{~N}$ padronizada com biftalato de potássio. As concentrações foram expressas em $\mathrm{mEq} / \mathrm{L}$ de ácido acético. $\mathrm{O} \mathrm{pH}$ foi medido em pHmetro digital da marca Mettler Toledo com precisão de $\pm 0,002$. 


\section{RESULTADOS E DISCUSSÃO}

\subsection{ATIVIDADE ANTIOXIDANTE PELO REAGENTE DPPH}

A atividade antioxidante baseada na redução do radical estável mostrou que os fermentados dos clones EMBRAPA 51 e BRS 189 foram capazes de inibir mais satisfatoriamente o DPPH, pois necessitam de uma menor concentração para reduzir em 50\% o radical. O fermentado CCP 76 foi o que mais se distanciou dos outros em relação a esse teste, tendo a pior atividade antioxidante, como pode ser observado na Figura 2.

Os resultados do potencial antioxidante por DPPH, quando comparados com os valores de Abe et al (2007), mostram um potencial similar aos cultivares de vinhos produzidos por cultivares Niagara. A presença de ácido ascórbico e dos compostos fitoquímicos presentes nos mostos provavelmente contribuem para este potencial, com diferentes composições destes compostos em cada cultivar.

Figura 2: valores da atividade antioxidante baseados na inibição do DPPH

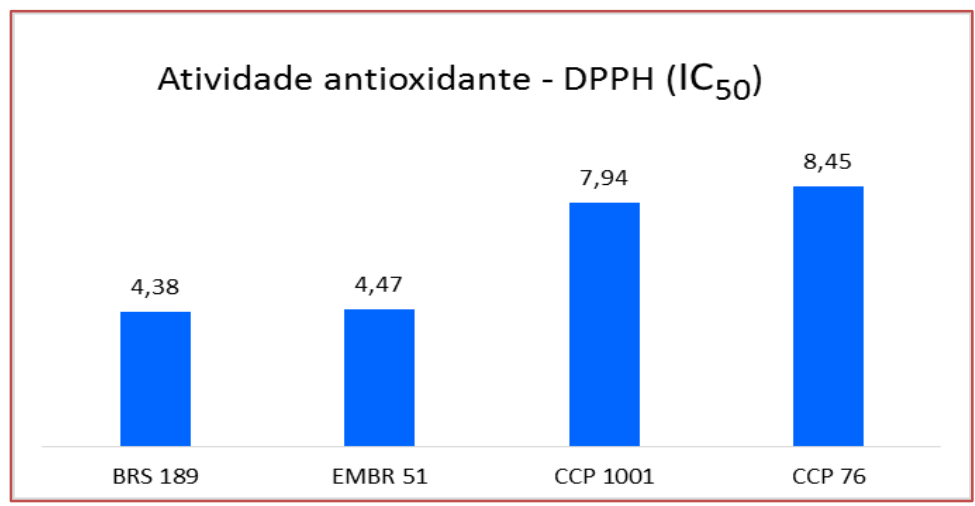

\subsection{ATIVIDADE ANTIOXIDANTE PELO MÉTODO FRAP}

Os fermentados apresentaram valores próximos de atividade antioxidante, como mostra a figura 3 . 0 que se destacou foi o fermentado do cultivar EMBRAPA 51, que foi capaz de reduzir mais moléculas de Fe+3 a $\mathrm{Fe}+2$, provavelmente por apresentar mais moléculas com esse potencial do que os outros fermentados.

Katalinic et al (2004) estudaram o potencial antioxidante por método FRAP de vinhos brancos e tintos. Ao comparar os resultados do potencial antioxidante com os do presente trabalho, observa-se maior atividade antioxidante dos fermentados obtidos em relação aos vinhos brancos avaliados pelos autores (2,85 mmol de $\mathrm{Fe}+2 / \mathrm{L})$, apresentando, porém, um menor potencial antioxidante frente aos vinhos tintos avaliados $(26,09 \mathrm{mmol}$ de $\mathrm{Fe}+2 / \mathrm{L})$. Provavelmente a presença de antocianinas presentes nos vinhos tintos contribuam para o aumento deste potencial em relação aos vinhos brancos e aos fermentados de caju.

Figura 3: valores da atividade antioxidante de cada fermentado pelo métodoFRAP,expressos em mMol $\mathrm{Fe}+2 / \mathrm{L}$.

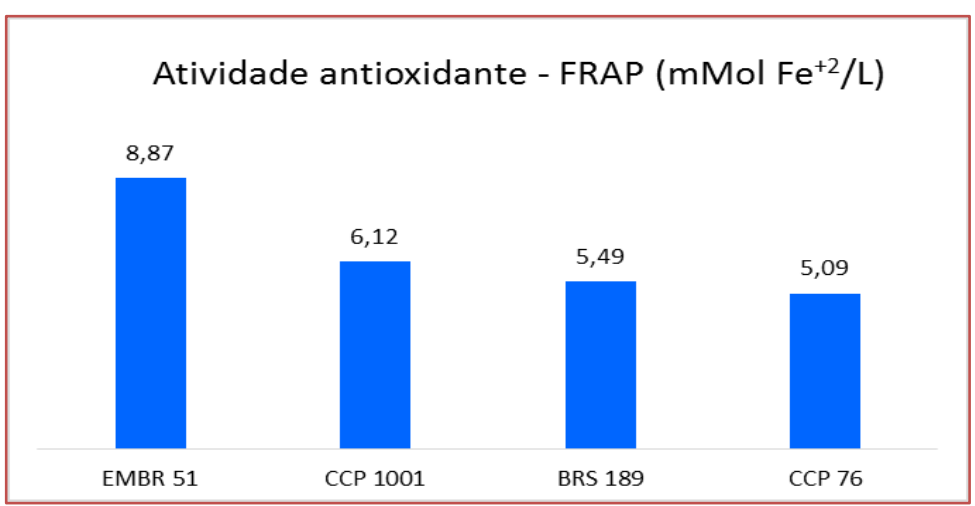




\section{AVALIAÇÃO DO TEOR DE ESTIRENO POR CROMATOGRAFIA GASOSA}

Os fermentados apresentaram teores de estireno próximos, com exceção do EMBRAPA 51 que se destacou com a menor concentração, conforme indica a figura 4. Isso mostra que a bioconversão de ácidos cinâmicos em estireno foi bem menor na fermentação do suco do cultivar EMBRAPA 51, ou seja, esse cultivar possivelmente apresenta uma composição menos propícia para a descarboxilação do estireno, ocasionado pela levedura. Infere-se também uma correlação entre a diminuição do teor de estireno com o aumento do potencial antioxidante do EMBRAPA 51.

Figura 4: teor de estireno dos fermentados expresso em parte por bilhão

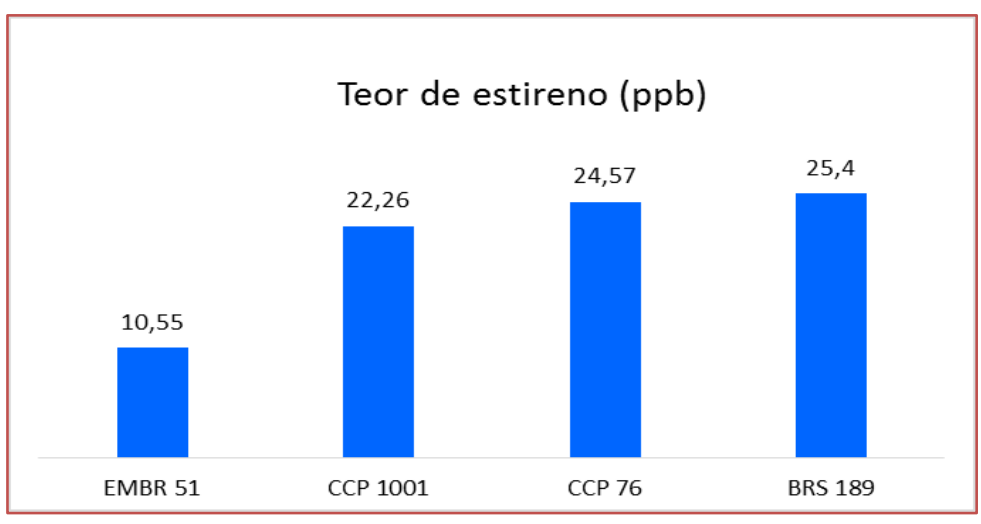

\subsection{ACIDEZ TOTAL TITULÁVEL E PH}

A acidez das bebidas está abaixo do limite máximo estabelecido em legislação (BRASIL, 2008), porém só a acidez do EMRAPA 51 ficou dentro do intervalo estabelecido, conforme tabela 1. Os valores de $\mathrm{pH}$ dos fermentados ficaram próximos, como mostra tabela 2, e dentro de uma faixa que sugere que não tenha ocorrido outro tipo de fermentação, como a acética, por exemplo.

Tabela 1: comparação dos resultados com parâmetros estabelecidos para fermentado de fruta. e valores de $\mathrm{pH}$

\begin{tabular}{|c|c|c|c|c|}
\hline \multirow{2}{*}{ Fermentado } & $\mathrm{mEq} / \mathrm{L} \mathrm{de}$ & $\begin{array}{c}\text { Intervalo } \\
\text { estabelecido }\end{array}$ & \multirow{2}{*}{ Fermentado } & \multirow{2}{*}{$\mathrm{pH}$} \\
\hline & $\mathrm{CH} 3 \mathrm{COOH}$ & $\begin{array}{l}\text { por legislação } \\
\text { (BRASIL. 2008) }\end{array}$ & & \\
\hline BRS 189 & 40 & $(50-130)$ & BRS 189 & 4,13 \\
\hline ССР 76 & 40,6 & $(50-130)$ & ССР 76 & 4,18 \\
\hline CCP 1001 & 46,12 & $(50-130)$ & CCP 1001 & 4,25 \\
\hline EMBR 51 & 58,4 & $(50-130)$ & EMBR 51 & 4,34 \\
\hline
\end{tabular}

\section{CONCLUSÕES}

Nota-se que apesar de todas as bebidas se tratarem de fermentado de caju, a atividade antioxidante entre eles é diferente, e também há uma grande diferença no teor de estireno desses fermentados, pois são oriundos de diferentes cultivares. De acordo com o meio, a levedura pode atuar gerando mais ou menos compostos indesejáveis. Portanto, o EMBRAPA 51 é o que apresenta melhores resultados para o objetivo deste trabalho. 


\section{REFERÊNCIAS}

[1] Abe, L. T.; Da Mota, R. T.; Lajolo, F. M.; Genovese, M. I.. (2007). Compostos fenólicos e capacidade antioxidante de cultivares de uvas Vitis labrusca L. e Vitis vinifera L. Ciência e Tecnologia de Alimentos, v.27, n.2, p.394-400.

[2] Aquarone, E.; Borzani, W.; Lima, U.; Schmidell. Biotecnologia Industrial. São Paulo: Editora Edgard Blücher, v. 4, p. 1-20, 2001.

[3] Benzie, I.F.F.; Strain, J.J. (1996). The Ferric reducing ability of plasma (FRAP) as a measure of "antioxidant power": The FRAP assay. Analytical Biochemistry, San Diego, v.239, p. 70-76.

[4] Brand-Williams, W.; Cuvelier, M.E.; Berset, C. Use of a free radical method to evaluate antioxidant activity. Food Science and Technology, v.28, p.25-30. 1995.

[5] BRASIL. Ministério da Agricultura, Pecuária e Abastecimento. Secretaria Nacional de Defesa Agropecuária. Instrução Normativa № 64, de 23 de abril de 2008. Aprovam os regulamentos técnicos para a fixação dos padrões de identidade e qualidade para as bebidas alcoólicas fermentadas. Diário Oficial [da] República Federativa do Brasil, Brasília, 24 de abril de 2008.

[6] Casimiro, A.R.S.; Feitosa, T.; Borges, M. de F.; Garruti, D. dos S.; Campos, J.O. de.; Bringel, M.H.F. (2000). Avaliação de leveduras industriais na fermentação de suco de caju. Fortaleza:Embrapa Agroindústria Tropical. 14p. (Embrapa AgroindústriaTropical. Circular Técnica, 4).

[7] Dato, M.C.F., Pizauro Júnior, J.M., Mutton, M.J.R. (2005) Analysis of the secondary compounds produced by Saccharomyces cerevisiae and wild yeast strains during the production of "Cachaça". Brazilian Journal of Microbiology, v.36, n.1, p.70-74.

Flak, W.; Tscheik, G. (1997) Determination of styrene in wine by solid phase micro extraction technology and GC-MS analysis. Mitt. Klosterneuburg, v.47, n.4, p.117-123.

[8] Instituto Adolfo Lutz. Normas Analíticas do Instituto Adolfo Lutz. v. 1: Métodos químicos e físicos para análise de alimentos. 3. ed. São Paulo: IMESP 1985.

[9] Katalinic, V.; Milos, M.; Modun, D.; Music, I.; Boban, M. (2004) Antioxidant effectiveness of selected wines in comparison with (+)-catechin. Food Chemistry, v.86, n.3, p.593-600.

[10] Torres Neto, A. B.; Silva, M. E.; Silva, W. B.; Swarnakar, R.; Silva, F. L. H. (2006) Cinética e Caracterização Físico-química do fermentado do pseudofruto de caju. Química Nova, v.29, n.3, p.489-492. 


\title{
Capítulo 15
}

\section{Conteúdo de bioativos e atividade antioxidante em cultivares de feijão-Caupi antes e após o cozimento}

\author{
Nara Vanessa dos Anjos Barros \\ Bruna Barbosa de Abreu \\ Marcos Antônio da Mota Araújo \\ Maurisrael de Moura Rocha \\ Regilda Saraiva dos Reis Moreira-Araújo
}

Resumo: 0 presente estudo avaliou o teor de compostos bioativos e atividade antioxidante antes e após o cozimento. Foram analisadas duas cultivares melhoradas geneticamente de feijão-caupi: BRS Aracê e BRS Tumucumaque. As análises foram realizadas em triplicata nas cultivares cruas e após o cozimento a vapor em panela de pressão doméstica. Determinaram-se os compostos bioativos, como os compostos fenólicos, flavonoides, antocianinas e taninos condensados, e a atividade antioxidante. Realizou-se a Análise de Variância e as médias foram comparadas pelos testes $\mathrm{t}$ de Student e Tukey $(\mathrm{p}<0,05)$. Para os compostos bioativos, a cultivar BRS Tumucumaque apresentou os maiores conteúdos de compostos fenólicos totais antes $(297,23 \mathrm{mg} / 100 \mathrm{~g}$ $\pm 4,24)$ e após $(147,15 \mathrm{mg} / 100 \mathrm{~g} \pm 6,94)$ o cozimento $(\mathrm{p}<0,05)$. Não foi detectada a presença de antocianinas nas cultivares. Para os teores de taninos condensados, verificou-se uma redução significativa nos grãos com o cozimento de $20-81 \%$. Para a atividade antioxidante, após o processamento, observou-se uma redução significativa $(\mathrm{p}<0,05)$. Para ambos os métodos avaliados, destacou-se a cultivar BRS Tumucumaque com os maiores teores para os grãos crus e cozidos. Concluiu-se que após o cozimento, as cultivares mantiveram o conteúdo de compostos fenólicos relevante.

Palavras-chave: Vigna unguiculata. Compostos fenólicos. Processamento térmico. 


\section{INTRODUÇÃO}

O feijão-caupi [Vigna unguiculata (L.) Walp.] é um dos alimentos e planta forrageira mais importante da região dos trópicos semi-áridos que incluem partes da Ásia, África, sul da Europa e dos Estados Unidos, América Central e do Sul. Os grãos de feijão-caupi possuem compostos bioativos com efeitos benéficos à saúde humana (SOMBIÉ et al., 2018). Dentre estes compostos, destacam-se os polifenois, que apresentam elevada atividade antioxidante (BARROS et al., 2017; NDERITU et al., 2013).

No feijão-caupi, os compostos fenólicos concentram-se no tegumento dos grãos, conferindo a maior parte da coloração das sementes desta leguminosa. Os principais tipos de polifenois presentes nas sementes de leguminosas, particularmente no caupi, são os ácidos fenólicos e flavonoides. Além disso, a quantidade de compostos fenólicos e as propriedades funcionais do feijão-caupi variam de acordo com a cultivar em estudo, e o processamento térmico aplicado. Diversos estudos mostraram que o cozimento reduz significativamente os níveis de compostos fenólicos e a atividade antioxidante (avaliada por ensaios in vitro) (BARROS et al., 2017; CAVALCANTE et al., 2017; SOMBIÉ et al., 2018).

Assim, o presente estudo visou avaliar o teor de compostos bioativos e atividade antioxidante antes e após o cozimento em cultivares biofortificadas de feijão-caupi.

\section{MATERIAL E MÉTODOS}

Foram analisadas duas cultivares melhoradas geneticamente de feijão-caupi: BRS Aracê e BRS Tumucumaque, fornecidas pela Empresa Brasileira de Pesquisa Agropecuária - Embrapa Meio-Norte, localizada em Teresina-Piauí. As amostras dos grãos crus foram trituradas em moinho de facas e peneiradas (30 mesh). 0 feijão-caupi foi cozido em uma proporção feijão: água de 1:3 (p/v) em panela de pressão doméstica de $2 \mathrm{~L}$, durante 13 minutos. Os grãos foram macerados e armazenados em sacos de polietileno $\left(+8^{\circ} \mathrm{C}\right)$ até o momento das análises.

0 conteúdo de fenólicos totais foi determinado de acordo com o método espectrofotométrico, utilizando o reagente Folin-Ciocalteau (SINGLETON; ROSSI, 1965), flavonoides totais segundo González-Aguilar et al. (2007) e as antocianinas totais seguindo-se o método de diferença de pH (GIUSTI; WROLSTAD, 2001). A determinação do teor de taninos condensados baseou-se no método da vanilina, segundo Price; Scoyoc e Butler, (1978). A atividade antioxidante foi determinada pelo método de captura dos radicais ABTS (RE et al., 1999) e FRAP (BENZIE e STRAIN, 1996). Todas as análises foram realizadas em triplicata e os resultados foram descritos em tabelas de frequência simples e expressos como média + desvio-padrão. Realizou-se a Análise de Variância (ANOVA) e as médias foram comparadas pelo teste Tukey, considerando o $\mathrm{p}<0,05$ para todos os testes.

\section{RESULTADOS E DISCUSSÃO}

Os teores de compostos fenólicos, flavonoides e taninos condensados antes e após o cozimento das cultivares de feijão caupi (Vigna unguiculata (L). Walp) analisadas estão demonstrados nas Tabelas 1 e 2.

Tabela 1 - Conteúdo de fenólicos totais e flavonoides totais em diferentes cultivares de feijão-caupi biofortificadas, em grãos crus e cozidos.

\begin{tabular}{|c|c|c|c|c|}
\multirow{2}{*}{ Cultivares } & \multicolumn{2}{|c}{ Fenólicos totais $(\mathrm{mg}$ EAG/100 g) } & \multicolumn{2}{c|}{ Flavonoides totais $(\mathrm{mg}$ EQ/100 g) } \\
& Grão cru & Grão cozido & Grão cru & Grão cozido \\
& Média $\pm \mathrm{DP}$ & Média \pm DP & Média \pm DP & Média \pm DP \\
\hline BRS Aracê & $227,98 \pm 4,12^{\mathrm{a}} \mathrm{A}$ & $126,58 \pm 0,00 \mathrm{bA}$ & $42,82 \pm 1,01^{\mathrm{a}} \mathrm{A}$ & $22,45 \pm 1,18 \mathrm{bA}$ \\
\hline BRS Tumucumaque & $297,23 \pm 4,24^{\mathrm{a}} \mathrm{B}$ & $147,15 \pm 6,94 \mathrm{bB}$ & $49,36 \pm 2,02^{\mathrm{a}} \mathrm{B}$ & $23,97 \pm 0,67 \mathrm{bA}$ \\
\hline
\end{tabular}

EAG: Equivalentes de Ácido Gálico. EQ: Equivalente de Quercetina. Letras subscritas minúsculas iguais entre os tipos de feijão cru e cozido, não há diferença significativa entre as médias segundo teste t de Student. Letras maiúsculas iguais entre os tipos de cultivares, não há diferença significativa entre as médias segundo o teste do one way ANOVA: post Hoc multiple comparisons, utilizou-se o teste de Tukey ao nível de 5\% p < 0,05, IC95\%. 
Observou-se que a cultivar BRS Tumucumaque apresentou os maiores teores de compostos fenólicos e flavonoides totais, nos grãos crus e cozidos. Resultado diferente do verificado por Barros et al. (2017), o qual ao avaliarem os teores de compostos bioativos das mesmas cultivares, o destaque ficou para a cultivar BRS Aracê.

Não foi identificada a presença de antocianinas totais nas amostras de feijão-caupi antes e depois do cozimento. Observou-se que houve uma redução significativa $(p \leq 0,05)$ no conteúdo de compostos fenólicos e flavonoides totais após o processamento para todas as cultivares avaliadas, conforme estudo similar desenvolvido por Cavalcante et al. (2017), no qual foram avaliadas cinco cultivares da leguminosa utilizando a mesma metodologia do presente estudo.

Tabela 2 - Conteúdo de taninos condensados em diferentes cultivares de feijão-caupi biofortificadas, em grãos crus e cozidos.

\begin{tabular}{|c|c|c|c|}
\hline \multirow{2}{*}{ Cultivares } & Grão cru & Grão cozido & Redução \\
\hline & Média \pm DP & Média \pm DP & $\%$ \\
\hline BRS Aracê & $4,72 \pm 0,00^{\mathrm{a}} \mathrm{A}$ & $3,75 \pm 0,00 \mathrm{bA}$ & 20,55 \\
\hline BRS Tumucumaque & $12,81 \pm 0,67 \stackrel{\mathrm{a}}{\mathrm{B}}$ & $2,35 \pm 0,00 \mathrm{bA}$ & 81,66 \\
\hline
\end{tabular}

Resultados expressos em mg/ 100 g. Letras subscritas minúsculas iguais entre os tipos de feijão cruz e cozido, não há diferença significativa entre as médias segundo teste $t$ de Student. Letras maiúsculas iguais entre os tipos de cultivares, não há diferença significativa entre as médias segundo o teste do one way ANOVA: post Hoc multiple comparisons, utilizou-se o teste de Tukey ao nível de 5\% p < 0,05, IC95\%.

Comparando os resultados da presente pesquisa com outros estudos, Sombié et al. (2018) avaliando 31 genótipos de feijão-caupi de Burkina Faso, obtiveram teores menores de compostos fenólicos $(63,14$ a 190,7 mg EAG/100 g) e flavonoides (7,46 a 23,95 EQ/100 g) que os da presente pesquisa. Para os teores de taninos condensados, verificou-se uma redução significativa nos grãos com o cozimento de 20-81\%, conforme tabela 2 .

Em relação à atividade antioxidante, para ambos os métodos avaliados, destacou-se a cultivar BRS Tumucumaque para os grãos crus e cozidos (Tabela 3).

Tabela 3 - Atividade antioxidante pelo método ABTS e FRAP em diferentes cultivares de feijão-caupi, em grãos crus e cozidos.

\begin{tabular}{|c|c|c|c|}
\hline \multirow{2}{*}{ Método } & \multirow{2}{*}{ Cultivares } & Grão cru & Grão cozido \\
\hline & & Média $\pm \mathrm{DP}$ & Média $\pm \mathrm{DP}$ \\
\hline \multirow{2}{*}{ ABTS } & BRS Aracê & $799,21 \pm 15,71^{\mathrm{a}} \mathrm{A}$ & $428,88 \pm 6,74 \mathrm{bA}$ \\
\hline & BRS Tumucumaque & $837,73 \pm 15,39$ - $B$ & $528,92 \pm 17,83 \mathrm{bB}$ \\
\hline \multirow{2}{*}{ FRAP } & BRS Aracê & $356,53 \pm 7,85^{\mathrm{a}} \mathrm{A}$ & $162,30 \pm 7,85 \mathrm{bA}$ \\
\hline & BRS Tumucumaque & $453,10 \pm 6,79 \underline{a} B$ & $274,86 \pm 2,61 b B$ \\
\hline
\end{tabular}

Resultados expressos em $\mu \mathrm{mol}$ de Equivalente ao Trolox/100 gramas. Letras subscritas minúsculas iguais entre os tipos de feijão cru e cozido, não há diferença significativa entre as médias segundo teste $t$ de Student. Letras maiúsculas iguais entre os tipos de cultivares, não há diferença significativa entre as médias segundo o teste do one way ANOVA: post Hoc multiple comparisons, utilizou-se o teste de Tukey ao nível de 5\% p < 0,05, IC95\%.

Após o processamento, observou-se uma redução significativa $(\mathrm{p}<0,05)$ na atividade antioxidante. Esta redução pode ter ocorrido devido ao processamento térmico promover a destruição de compostos bioativos levando à redução dos mesmos, e/ou a formação de novos compostos com ação pró-oxidante. Pode-se observar que o método de captura dos radicais ABTS foi o mais eficaz na determinação da atividade antioxidante, pois foram observados os maiores teores tanto no grão cru quanto no cozido, de forma similar ao verificado por Cavalcante et al. (2017). 
Considerando os grãos crus, os resultados obtidos no presente estudo para o ensaio FRAP foram maiores que os verificados no estudo de Sombié et al. (2018), que variaram de 25,51 a 311,46 mg EQ/100 g. Além disso, estes resultados foram superiores aos obtidos no estudo de Chaieb et al. (2011), ao analisarem a capacidade antioxidante in vitro de treze genótipos de feijão do tipo fava (Vicia faba L.).

\section{CONCLUSÕES}

Concluiu-se que após o cozimento, as cultivares mantiveram um conteúdo de compostos fenólicos relevante com destaque para a cultivar BRS Tumucumaque para os teores de compostos bioativos e atividade antioxidante.

\section{REFERÊNCIAS}

[1] BARROS, N. V. A. et al. Effect of cooking on the bioactive compounds and antioxidant activity in grains cowpea cultivars. Revista Ciência Agronômica, v. 48, n. 5 (Especial), p. 824-831, 2017.

[2] BENZIE, I.F.F.; STRAIN, J.J. A capacidade de redução férrica do plasma (FRAP) como uma medida do poder antioxidante: o ensaio FRAP. Analytical Biochemistry, v. 239, p. 70-76, 1996.

[3] CAVALCANTE, R. B. M. et al. Effect of thermal processing on chemical compositions, bioactive compounds, and antioxidant activities of cowpea cultivars. Revista Caatinga, v. 30, n. 4, p. 1050 - 1058, 2017.

[4] CHAIEB, et al. Polyphenols content and antioxidant capacity of thirteen faba bean (Vicia faba L.) genotypes cultivated in Tunisia. Food Research International, v. 44, n. 4, p. 970-977, 2011.

[5] GIUSTI, M. M.; WROLSTAD, R. E. In: R. E. Wrolstad (Ed.), Anthocyanins: Characterization and measurement with UV-visible spectroscopy. Current Protocols in Food Analytical Chemistry. New York: J. Wiley, \& and Sons, p.1-13, 2001.

[6] GONZÁLEZ-AGUILAR, G. A. et al. Improving antioxidant capacity of fresh-cut mangoes treated with UV-C. Journal of Food Science, v. 72, s197-s202, 2007.

[7] NDERITU, A. M. et al. Phenolic composition and inhibitory effect against oxidative DNA damage of cooked cowpeas as affected by simulated in vitro gastrointestinal digestion. Food Chemistry, v. 141, n. 3, p. 1763-1771, 2013.

[8] PRICE, M. L.; SCOYOC, S. V.; BUTLER, L. G. A critical evaluation of the vanillin reaction as an assay for tannin in sorghum grain. Journal of Agriculture and Food Chemistry, v. 26, n. 5, p. 1214-1218, 1978.

[9] RE, R. et al. Antioxidant activity applying an improved ABST radical cation decolorization assay. Free Radical Biology \& Medicine, v. 26, n. 9-10, p. 1231- 1237, 1999.

[10] SINGLETON, V. I.; ROSSI, J. Colorimetry of total phenolic with phosphomolybdic-phosphotungstic acid agents. American Journal of Enology and Viticulture, v. 16, n. 3, p. 144-158, 1965.

[11] SOMBIÉ, P. A. E. D. et al. Antioxidant and Phytochemical Studies of 31 Cowpeas (Vigna unguiculata (L. Walp.)) Genotypes from Burkina Faso. Foods, v. 7, n. 143, p. 1-9, 2018. 


\section{Capítulo 16}

Quantificação da capacidade antioxidante e compostos bioativos presentes no Quipá Tacinga Inamoena ( $k$. Schum) NP Taylor \& Stuppy

\section{Ana Cibele Pereira Sousa \\ Myrella Pereira Pinto \\ Maurício Eduardo Matos Cavalcante \\ Stella Regina Arcanjo Medeiros \\ Alessandro de Lima}

Resumo: A caatinga destaca-se como o ecossistema com a maior diversidade dessas espécies, muitas dessas, apesar do elevado potencial nutricional e de compostos bioativos ainda são pouco exploradas, dentre essas tem-se as cactáceas as quais são plantas xerofíticas com alto poder de adaptação à climas secos e à elevadas temperaturas. Este estudo objetivou avaliar a capacidade antioxidante e o teor de compostos bioativos antocianinas, e o teor de carotenoides e vitamina $\mathrm{C}$ do fruto do quipá (Tacinga inamoena (K. Schum) NPTaylor \& Stuppy). Observou-se que a fruta tanto a polpa quanto a casca são ricos nesses compostos com destaque para essa última, com o destaque para o valor de carotenoides totais, Dessa forma, infere-se que o quipa contem atividade antioxidante e compostos bioativos, mais estudos são necessários para avaliar parâmetros tais como toxicidade in vivo bem como investimentos ao desenvolvimento de novos produtos à base deste.

Palavras-chave: cactáceas; compostos bioativos; quipá. 


\section{INTRODUÇÃO}

A família Cactaceae Juss. é composta aproximadamente de 124 gêneros e 1.440 espécies, distribuídas quase exclusivamente nas regiões tropicais e secas das Américas, com exceção da espécie Rhipsalis baccifera, que pode ocorre na África, em Madagascar e no Sri Lanka. Esses cactos podem se apresentar como árvores, arbustos, trepadeiras, epífitas, geófitas e hastes (talos) com aspectos que podem variar de colunares a roliços, globulares ou tuberculados, com forma de costeletas, asas, achatados, geralmente segmentados sem folhas e com espinhos (BARTHLOTT; HUNT, 1993: HUNT; TAYLOR; CHARLES, 2006). A sua propagação pode ser realizada de forma sexuada ou assexuada, sendo a primeira um método ainda pouco utilizado (ABUD et al., 2010).

Estes possuem um elevado poder de adaptação a altas temperaturas diurnas, altas radiações, baixas temperaturas noturnas, e baixo teor de água. Fisiologicamente são caracterizadas por possuir o metabolismo ácido das crassuláceas CAM (ou MAC). As plantas CAM (do inglês, Crassulacean Acid Metabolism), são plantas especialmente adaptadas a regiões áridas e semiáridas, o que permite retenção de água em seu interior e a sua utilização de forma diferenciada, abrem seus estômatos durante a noite e os fecham durante o dia, o que gera uma alta eficiência no uso da água (PEREIRA et al., 2013).

Dentre essas espécies tem-se o quipá (Tacinga inamoena (K. Schum) NPTaylor \& Stuppy) é uma espécie popularmente conhecida como cumbeba ou gogóia (Figura 8). Seus frutos são do tipo baga ovóide a subgloboso, com 3,0-4,0 x 2,4-3,5 cm de diâmetro longitudinal e transversal, respectivamente. A cor de sua casca varia do amarelo ao laranja fosco, com porção basal avermelhada ou toda vermelha fosca; sua câmara seminífera ocupando quase todo o espaço interno, e é preenchido por uma massa carnosa de cor pêssego clara, constituída pelos funículos e sementes (Figura 9) (ANDRADE LIMA, 1989).

Ao avaliarem as características desse fruto, Souza et al., (2007), verificaram que este é adequado para o consumo in natura e apresenta potencial para aproveitamento industrial. Além de apresentarem valores consideráveis de minerais, destacando-se dentre estes o cálcio, o magnésio e o potássio. Os frutos e cladódios têm sido utilizados na zona rural para alimentação animal, apesar do sabor suave, pouco doce e apresentar maior proporção de porção carnosa $(62,87 \%)$ do que casca, há poucos relatos de sua inserção na dieta humana. Este estudo teve como objetivo avaliar a capacidade antioxidante pelo método DPPH e o teor de compostos bioativos de frutos de quipá da caatinga Piauiense.

\section{METODOLOGIA}

Os frutos do quipá (Tacinga inamoena (K. Schum) NPTaylor \& Stuppy), TEPB 30.824, foram colhidos na zona rural de cidade de Caldeirão Grande do Piauí (07ำ19'55" latitude sul e a uma longitude 40³8'14" oeste). A partir das cascas e o polpa do fruto se quantificou os seguintes compostos Bioativos: antocianinas, carotenoides e vitamina c.

Para determinação de antocianinas, seguiu-se a metodologia descrita por Francis (1982). Pesou-se 0,5 g da amostra em um erlenmeyer envolto com papel alumínio, acrescendo em seguida $10 \mathrm{~mL}$ da solução de etanol $95 \%+\mathrm{HCl} 1,5 \mathrm{~N}$ previamente elaborada (85:15).

A determinação do teor de carotenoides foi realizada segundo o método descrito por Rodriguez-Amaya (2001). Realizou-se a leitura em espectrofotômetro a $450 \mathrm{~nm}$ ( $\lambda \max ß$-caroteno), usando éter de petróleo como branco.

O ácido ascórbico (Vitamina C) foi analisado pelo método de Tilmans, que se baseia na redução do sal sódico 2,6-diclorofenol indofenol (DCFI) pelo ácido ascórbico (INSTITUTO ADOLF LUTZ, 2008).

Para a analise de antioxidante foram preparadas extratos das polpas e cascas dos frutos foram obtidos utilizando solventes de diferentes polaridades: extratos aquoso, etanólico e acetônico (SOUSA; VIEIRA; LIMA, 2011), utilizando-se água destilada, álcool etílico absoluto (PA) e acetona (PA). Cinco diluições em concentrações diferentes de cada extrato para avaliação da atividade antioxidante pelo método de captura do radical livre DPPH•, descrita por Brand-Wyllians, Cuvelier e Berset (1995).

A análise dos resultados foi realizada por meio de cálculo de médias e desvio-padrão, análise de variância e aplicação do teste de Tukey $(\mathrm{p}<0,05)$ com auxílio do programa ASSISTAT versão 7.7 Beta e GraphPad Prism 6. 


\section{RESULTADOS}

Os valores médios para os compostos bioativos das cascas e polpas do fruto estão apresentados na Tabela 1.

Tabela 1 - Teor de compostos bioativos presentes nas polpas e cascas do quipá (Tacinga inamoena (K. Schum) NPTaylor \& Stuppy).

\begin{tabular}{|c|c|c|}
\hline Composto Bioativo & Polpa & Casca \\
\hline Ácido ascórbico (mg.100g-1) & $20,30^{b} \pm 0,54$ & $26,88^{\underline{a}} \pm 0,47$ \\
\hline Carotenoides totais $\left(\mu \mathrm{g} .100 \mathrm{~g}^{-1}\right)$ & $128,41^{\mathrm{b}} \pm 0,07$ & $192,94^{a} \pm 0,14$ \\
\hline Antocianinas (mg.100 $\mathrm{g}^{-1}$ ) & $0,16^{\mathrm{b}} \pm 0,03$ & $0,20^{a} \pm 0,03$ \\
\hline
\end{tabular}

Valores expressos em média \pm desvio padrão

Médias seguidas pela mesma letra, na mesma coluna, (por parâmetro e parte do fruto) não diferem estatisticamente entre si, pelo teste de Tukey $(\mathrm{p}<0,05)$.

Tabela 2 - Atividade antioxidante, expressos pelo percentual de proteção (\%) pelo método de sequestro do radical DPPH dos extratos aquoso, etanólico e acetônico das polpas e cascas do quipá (Tacinga inamoena (K. Schum) NPTaylor \& Stuppy)

\begin{tabular}{|c|c|c|c|c|c|c|}
\hline Extrato & \multicolumn{6}{|c|}{ Concentração $\left(\mu \mathrm{g} \cdot \mathrm{mL}^{-1}\right)$ e Porcentual de Proteção (\%) } \\
\hline \multirow{3}{*}{ Polpa } & EAQ & $\begin{array}{l}200 \mu \mathrm{g} \cdot \mathrm{mL}^{-1} \\
20,67 \pm 2,96\end{array}$ & $\begin{array}{c}300 \mu \mathrm{g} \cdot \mathrm{mL}^{-} \\
123,00 \pm 0,25\end{array}$ & $\begin{array}{c}600 \mu \mathrm{g} \cdot \mathrm{mL}^{-} \\
127,02 \pm 0,64\end{array}$ & $\begin{array}{c}800 \mu \mathrm{g} \cdot \mathrm{mL}^{-} \\
133,62 \pm 8,77\end{array}$ & $\begin{array}{c}1000 \mu \mathrm{g} \cdot \mathrm{mL}^{-} \\
135,70 \pm 0,65\end{array}$ \\
\hline & EET & $\begin{array}{l}200 \mu \mathrm{g} \cdot \mathrm{mL}^{-1} \\
20,07 \pm 1,42\end{array}$ & $\begin{array}{c}400 \mu \mathrm{g} \cdot \mathrm{mL}^{-} \\
125,57 \pm 0,70\end{array}$ & $\begin{array}{c}600 \mu \mathrm{g} \cdot \mathrm{mL}^{-} \\
130,83 \pm 0,74\end{array}$ & $\begin{array}{c}800 \mu \mathrm{g} \cdot \mathrm{mL}^{-} \\
134,44 \pm 1,20\end{array}$ & $\begin{array}{c}1200 \mu \mathrm{g} \cdot \mathrm{mL}^{-} \\
138,71 \pm 1,89\end{array}$ \\
\hline & EAC & $\begin{array}{l}200 \mu \mathrm{g} \cdot \mathrm{mL}^{-1} \\
34,32 \pm 1,02\end{array}$ & $\begin{array}{c}400 \mu \mathrm{g} \cdot \mathrm{mL}^{-} \\
137,36 \pm 0,18\end{array}$ & $\begin{array}{c}600 \mu \mathrm{g} \cdot \mathrm{mL}^{-} \\
141,50 \pm 1,06\end{array}$ & $\begin{array}{c}800 \mu \mathrm{g} \cdot \mathrm{mL}^{-} \\
144,91 \pm 0,67\end{array}$ & $\begin{array}{c}1200 \mu \mathrm{g} \cdot \mathrm{mL}^{-} \\
152,63 \pm 0,25\end{array}$ \\
\hline \multirow{3}{*}{ Casca } & EAQ & $\begin{array}{l}100 \mu \mathrm{g} \cdot \mathrm{mL}^{-1} \\
26,65 \pm 0,07\end{array}$ & $\begin{array}{c}200 \mu \mathrm{g} . \mathrm{mL}^{-} \\
128,91 \pm 0,57\end{array}$ & $\begin{array}{c}300 \mu \mathrm{g} \cdot \mathrm{mL}^{-} \\
129,37 \pm 0,14 \\
\end{array}$ & $\begin{array}{c}500 \mu \mathrm{g} \cdot \mathrm{mL}^{-} \\
133,54 \pm 0,07\end{array}$ & $\begin{array}{c}600 \mu \mathrm{g} . \mathrm{mL}^{-} \\
137,09 \pm 0,54\end{array}$ \\
\hline & EET & $\begin{array}{l}100 \mu \mathrm{g} \cdot \mathrm{mL}^{-1} \\
27,91 \pm 0,06\end{array}$ & $\begin{array}{c}200 \mu \mathrm{g} \cdot \mathrm{mL}^{-} \\
135,74 \pm 0,06\end{array}$ & $\begin{array}{c}300 \mu \mathrm{g} \cdot \mathrm{mL}^{-} \\
136,26 \pm 0,52\end{array}$ & $\begin{array}{c}500 \mu \mathrm{g} \cdot \mathrm{mL}^{-} \\
150,56 \pm 5,58\end{array}$ & $\begin{array}{c}600 \mu \mathrm{g} \cdot \mathrm{mL}^{-} \\
158,43 \pm 0,36\end{array}$ \\
\hline & EAC & $\begin{array}{l}100 \mu \mathrm{g} \cdot \mathrm{mL}^{-1} \\
33,19 \pm 0,59\end{array}$ & $\begin{array}{c}200 \mu \mathrm{g} \cdot \mathrm{mL}^{-} \\
137,23 \pm 0,43\end{array}$ & $\begin{array}{c}300 \mu \mathrm{g} \cdot \mathrm{mL}^{-} \\
141,68 \pm 1,02\end{array}$ & $\begin{array}{c}500 \mu \mathrm{g} \cdot \mathrm{mL}^{-} \\
153,05 \pm 0,33\end{array}$ & $\begin{array}{c}600 \mu \mathrm{g} \cdot \mathrm{mL}^{-} \\
154,64 \pm 0,34\end{array}$ \\
\hline
\end{tabular}

Valores expressos em média \pm desvio padrão

EAQ - extrato aquoso, EET- extrato etanólico e EAC- extrato acetônico

\section{DISCUSSÃO}

Ao avaliar a tabela 01 infere-se que Quipá é fonte de compostos bioativos (vitamina c, carotenóidoes totais e antocianinas) tanto na polpa quanto na casca em proporções variadas. Esse estudo é pioneiro neste tipo de avaliação, portanto os resultados encontrados foram confrontados com outros frutos, pela inexistência de estudos prévios com essas matrizes alimentares.

A casca e polpa do quipá apresentaram elevados teores de ácido ascórbic, no entanto esses valores são inferiores se comparados ao verificados por Brunini e Cardoso (2011) ao avaliarem a polpa da Pitaia Hylocereus undatus (Haw.) Britton \& Rose) onde obtiveram 28,19mg/100g. No entanto os valores reportados para todas as cascas são superiores a casca dessa mesma fruta (Hylocereus undatus) avaliada por Mello et al. (2014) que observou a variação de 7,62 $\pm 2,21$ e 7,04 $\pm 0,88 \mathrm{mg} / 100 \mathrm{~g}$ dessa vitamina nos anos de 2011 e 2012.

A vitamina $C$ está envolvida na manutenção das funções corporais, sendo este importante na captação de espécies reativas de oxigênio viabilizando a manutenção do microambiente interno determinado pelo equilíbrio redox, tal disfunção está relacionada com doenças tais como a obesidade, doenças neurodegenerativas, hipertensão e doenças auto-imunes (FIGUEROA-MÉNDEZ; RIVAS-ARANCIBIA, 2015).

É crescente a procura de extensa parcela da população mundial por alimentos que além de nutrir ofereçam benefícios a saúde. Esse benefício é obtido através do consumo de compostos ou elementos biologicamente ativos, entre estes estão os carotenoides (SENTANIN; RODRIGUEZ-AMAYA, 2007). 
Os teores de carotenoides estão entre os componentes de alimentos mais afetados por fatores genéticos e ambientais, nos alimentos eles podem conferir cor (amarelo, laranja ou vermelho), e são percussores de aroma. Em se tratando de saúde além de possuir atividade pro-vitamínica esses compostos tem sido associada com a redução do risco de desenvolvimento de doenças crônicas como câncer, doenças cardiovasculares, catarata e degeneração macular (RODRIGUEZ-AMAYA, 2015). Quanto ao teor de desse composto a casca apresentou um maior valor comparado com a polpas $(\mathrm{p}<0,05)$.

Observa-se uma pequena presença de antocianinas na polpa e casca próximo aos de frutos tropicais não tradicionais brasileiros como o bacuri e umbu ambos com $0,3 \pm 0,2 \mathrm{mg} / 100 \mathrm{~g}$ e Gurguri 3,30,2mg/100g (RUFINO el al., 2010).

O elevado consumo de antocianinas é correlacionado com níveis mais baixos de proteína C reativa (PCR), a qual é um biomarcador para a inflamação crônica e um fator de risco para doenças cardiovasculares (DCV) (CHUN et al., 2008).

Verifica-se na tabela 2 que cada extrato possui um comportamento distinto de acordo com a parte do fruto e a concentração testada. Dos extratos testados destacam-se principalmente os provenientes das cascas que reagiram com os radicais $\mathrm{DPPH} \bullet$ em menores concentrações $100 \mu \mathrm{g} \cdot \mathrm{mL}^{-1}$, apresentaram altos percentuais de proteção chegando a $58,43 \pm 0,36 \%$, Já a polpa precisou de concentrações maiores para reagirem.

\section{CONCLUSÃO}

$\mathrm{O}$ fruto avaliado mostra-se como boa fonte de compostos bioativos ( vitamina C, carotenoides totais e antocianinas ) e antioxidante pelo método do DPPH com destaque para o maior valor encontrado na casca do fruto em relação a polpa. No entanto estudos adicionais são necessários para um melhor aprofundamento e confirmação das propriedades bioativas e não tóxicas desses frutos, a partir de ensaios in vivo.

\section{REFERÊNCIAS}

[1] Instituto Adolfo Lutz. Normas analíticas do Instituto Adolfo Lutz. Métodos físico-químicos para análise de alimentos. 4. ed. São Paulo: Instituto Adolfo Lutz, 2008. 1020 p.

[2] Abud H. F.; Gonçalves, N. R.; Reis, R. G. E.; Pereira, D. S.; Bezerra, A. M. E. Germinação e expressão morfológica de frutos, sementes e plântulas de Pilosocereus pachycladus Ritter. Revista Ciência Agronômica, v. 41, n. 3, p. 468-474, 2010.

[3] Barthlott, W.; Hunt. D. R. Cactaceae. In: The families and genera of vascular plants, v. II flowering plants Dicotyledons. Kubiztki, K; Rohwer, JG; Bittrich, V. Berlin: Springer-Verlag, 1993. p. 161-197.

[4] Brand-Willians, W.; Cuvelier, M. E.; Berset, C. Use of a free radical method to evaluate antioxidant activity. Lebensmittel-Wissenschatt und-technologie, v. 28, n. 1, p. 25-30, 1995.

[5] Brunini, M. A.; Cardoso, S. S. Qualidade de pitaias de polpa branca armazenadas em diferentes temperaturas. Revista Caatinga, v. 24, n. 3, p. 78-84, 2011.

[6] Chun, O. K.; Chung, S. J.; Claycombe, K. J.; Canção, W. O. Serum C-reactive protein concentrations are inversely associated with dietary flavonoid intake in U.S. adults. The Journal of nutrition, v. 138, n.4, p. 753-760, 2008.

[7] Figueroa-Méndez, R.; Rivas-Arancibia, S. Vitamin C in health and disease: Its role in the metabolism of cells and redox state in the brain. Frontiers in Physiology, v. 6, p. 1-11, 2015.

[8] Francis, F. J. Analysis of anthocyanins. In:Markakis, P. (Ed.), Anthocyanins as food colors. New York: Academic Press, p. 181-207. 1982.

[9] Hunt, D. R.; Taylor, N.; Charles, G. The New Cactus Lexicon. Text. dh Publications, Milborne Port, 2006. 900p.

[10] Mello, F. R. DE; Bernardo, C.; Dias, C. O. ; Züge, E. R. B.; Silveira, J. L. M.; Amante, E. R. ; Candido, L. M. B. Evaluation of the chemical characteristics and rheological behavior of pitaya ( Hylocereus undatus) peel. Fruits, v. 69, n. 5, p. 381-390, 2014.

[11] Pereira, F. C.; Lima, V. L. A.; Moreira, A. A. D.; Rocha, C. S.; Lima, A. K. V. O. Fenologia do xiquexique (Pilosocereus gounellei, A. Weber ex K. Schum.) cultivados em áreas degradas no seridó Paraibano. Revista Educação Agrícola Superior, v. 28, n. 2, p. 85-91, 2013.

[12] Rodriguez-Amaya, D. B. A guide to carotenoid analysis in foods. Washington: ILSI Press, 2001, 71p. 
[13] Sentanin, M.; Rodriguez-Amaya, D. Teores de carotenóides em mamão e pêssego determinados por cromatografia líquida de alta eficiência. Ciência e Tecnologia de Alimentos, v. 27, n. 1, p. 13-19, 2007.

[14] Rodriguez-Amaya, D. B. Status of carotenoid analytical methods and in vitro assays for the assessment of food quality and health effects. Current Opinion in Food Science, v. 1, p. 56-63, 2015.

[15] Rufino, M. Do S. M.; Alves, R. E.; Brito, E. S. DE, Pérez-Jiménez, J.; Saura-Calixto, F.; Mancini-Filho, j. Bioactive compounds and antioxidant capacities of 18 non-traditional tropical fruits from Brazil. Food Chemistry, v. 121, n. 4, p. 996-1002, 2010.

[16] Souza, A. C. M. S.; Gamarra-Rojas, G.; Andrade, S. A. C.; Guerra, N. B. Características físicas, químicas e organolépticas de quipá (Tacinga Inamoena, Cactaceae). Revista Brasileira de Fruticultura, v. 29, n. 2, p. 292-295, 2007.

[17] Sousa, M. S. B.; Vieira, L. M.; Lima, A. DE. Fenólicos totais e capacidade antioxidante in vitro de resíduos de polpas de frutas tropicais. Brazilian Journal of Food Technology, v.14, n. 3, p. 202-210, 2011. 


\section{Capítulo 17}

Aplicação da microscopia eletrônica de varredura na identificação do comportamento morfológico da farinha de algaroba obtida em diferentes tipos de moinhos

\section{Alan Henrique Texeira \\ Clovis Queiroz Gouveia \\ Clóvis Gouveia da Silva \\ Karina da Silva Falcão}

Resumo: 0 desenvolvimento sustentável de uma região deve focar na transformação racional dos seus recursos naturais em benefícios para os seus habitantes, sem impactar o meio ambiente nem comprometer a existência das futuras gerações. É neste contexto, que entra a algarobeira (Prosopis juliflora (Sw) D.C.), com seus frutos doces e aromáticos. Semelhante a outras farinhas convencionais (trigo, milho e mandioca) a farinha de algaroba pode ser aplicada nas formulações de pães, bolos, farofas, etc. Daí a importância desse estudo, que teve como objetivo estudar o comportamento da farinha de algaroba, através da técnica instrumental de varredura eletrônica por microscopia, em amostras submetidas a diferentes tipos de moinhos. 0 processo consistiu das seguintes operações unitárias: coleta da matéria-prima, seleção e preparo das amostras, secagem, moagem e peneiramento. Em seguida as amostras foram submetidas a análise por microscopia eletrônica de varredura. Os resultados mostraram que: o efeito obtido para cada tipo de moinho é muito variável e depende da sua estrutura interna e modo de funcionamento, para tanto, observou-se os efeitos morfológicos mudaram de acordo com a farinha de algaroba em cada moinho. Portanto, conclui-se que, um dos moinhos teve vantagem em relação aos demais e influencia significativamente tanto na estrutura morfológica, como no rendimento processo.

Palavras-chave: Prosopis, mesquite, algaroba, farinha, MEV. 


\section{INTRODUÇÃO}

O Brasil é um país abundante em variabilidade natural, onde buscam-se formas de explorar recursos sem destruir o meio ambiente com um uso consciente e racional. Em meio a estas perspectivas os recursos naturais ganham força nas novas tecnologias, com desenvolvimento de novos estudos baseados em meios renováveis sem maltratar o meio ambiente de forma a repor o que é retirado na natureza (CARIOCA, 2010).

Segundo Dong (2012), por meio da realização de estudos ao longo dos anos vem sendo possível perceber que é possível utilizar matérias-primas renováveis para dar origem a produtos úteis no cotidiano. Por meio da extração de produtos vindos da natureza como os polissacarídeos e polímeros naturais suas expectativas para as aplicações destes produtos vem sendo cada dia mais investigada.

Neste contexto sobre recursos renováveis surge a Algarobeira do gênero Prosopis pertence à família Leguminosae, abundante no semiárido do Nordeste brasileiro. Árvore de grande porte que pode atingir 20 metros de altura, crescem em regiões áridas e semiáridas do planeta. Frutificam em épocas secas podendo alimentar animais, pois seus frutos apresentam um grande potencial energético e nutricional, quando transformados em farinha se assemelham ao trigo, milho e outros cereais (SILVA, 2003; PEREZ, 1991).

Sua produção de vagens é abundante foi introduzida no Nordeste com o intuito de alimentar animais e no plantio para reflorestamento. Hoje em dia aparece em diversos âmbitos, como na produção de produção de madeira, carvão vegetal, estacas, álcool, melaço, alimentação animal e humana, apicultura, reflorestamento, ajardinamento e sombreamento (SILVA, 2001; VIEIRA,1995).

Através da abundância da algaroba tem-se como objetivo estudar o comportamento da farinha de algaroba, através de processos de peneiramento, secagem e da técnica instrumental de microscopia eletrônica de varredura em amostras submetidas a diferentes tipos de moinhos.

0 peneiramento tem o intuito de separar um determinado material em mais de uma fração, com tamanhos distintos. Nesta operação unitária existe separação por tamanho geométrico. No peneiramento existem escalas para o seu uso como a de Tyler e Richards onde o número de malhas (mesh) representa o número de aberturas de uma mesma dimensão contido num comprimento de 25,4 mm (CARRISSO, 2004).

Já o processo de secagem é a operação unitária que tem por destino remover todo e qualquer líquido que possa ser retirado do material analisado, em secagem as remoções de líquidos são por materiais sólidos, remoção por centrifugação ou vaporização (CELESTINO, 2010).

A microscópia eletrônico de varredura (MEV) tem como objetivo analisar a morfologia e elementos químicos que compõem as amostras sólidas. Sua utilização é ampla atinge diversas áreas de estudo. Através do MEV pode-se observar as imagens com resolução de $1 \mathrm{~nm}$ além de possuir uma aparência 3D e é possível aumentar ou diminuir pontos específicos desejados (DEDAVID, 2007).

As análises do MEV são submetidas a um feixe de elétrons como entra em contato com a amostra diversas radiações são liberadas. Para diminuir a irradiação da superfície que foi irradiada é possível recobrir ou reduzir a alta voltagem do feixe de elétrons sobre o material, porém este procedimento pode diminuir a carga total o que irá diminuir a qualidade das imagens que serão disponibilizadas pelo MEV (SAWYER, 1996).

O MEV vem sendo cada vez mais utilizado por possibilitar a utilização de um aumento de até 3000 vezes na imagem desejada, com detalhes morfológicos interessantes para pesquisas em diversas áreas, dentre elas, engenharia, química e alimentos (REED, 1996).

Por meio da ordem de análises descritas acima ao fim do processo será analisado qual o método mais recomendado para este tipo de amostra.

\section{METODOLOGIA}

Este trabalho foi realizado no Laboratório de Análises e Pesquisas de Bebidas Alcoólicas (LBA) da Universidade Federal da Paraíba (UFPB), conjuntamente, com o Laboratório de Modelagem em Materiais da UFPB, ambos localizado no Estado da Paraíba.

Os frutos da algarobeira, Prosopis juliflora (S.w.) D.C., utilizados, neste trabalho, foram provenientes da cidade paraibana de Patos, situada na mesorregião do sertão Paraibano. Estes frutos foram coletados, manualmente, após queda natural, no mês de setembro de 2018. 
A princípio, foi feita uma seleção das vagens de algaroba excluindo-se as vagens que apresentavam problemas com pragas, mofos, atrofiamento e defeitos que visualmente foram identificados. Após selecionar o material, cortou-se em pedaços com no máximo $3 \mathrm{~cm}$ de comprimento e pesou-se em uma balança semi analítica de precisão de 0,1 g sendo esses separados em 3 bandejas, B1, B2 e B3 como mostrado na Fig. 1, com pesos de $250 \mathrm{~g}$.

Figura 1- Bandejas preparadas para secagem.

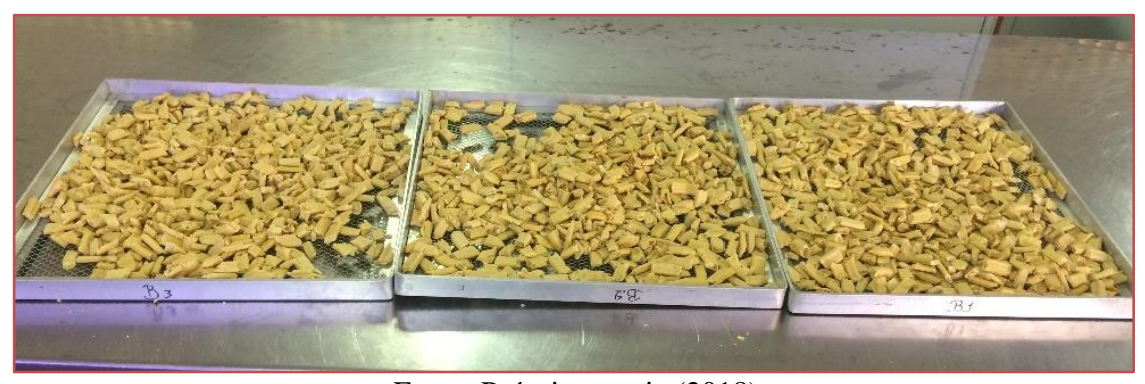

Fonte: Própria autoria (2018).

Levou-se o material para uma estufa de secagem a $65{ }^{\circ} \mathrm{C}$ por mais ou menos 8 horas a fim de remover umidade até um peso constante de amostra.

Figura 2 - Secagem das amostras na estufa.

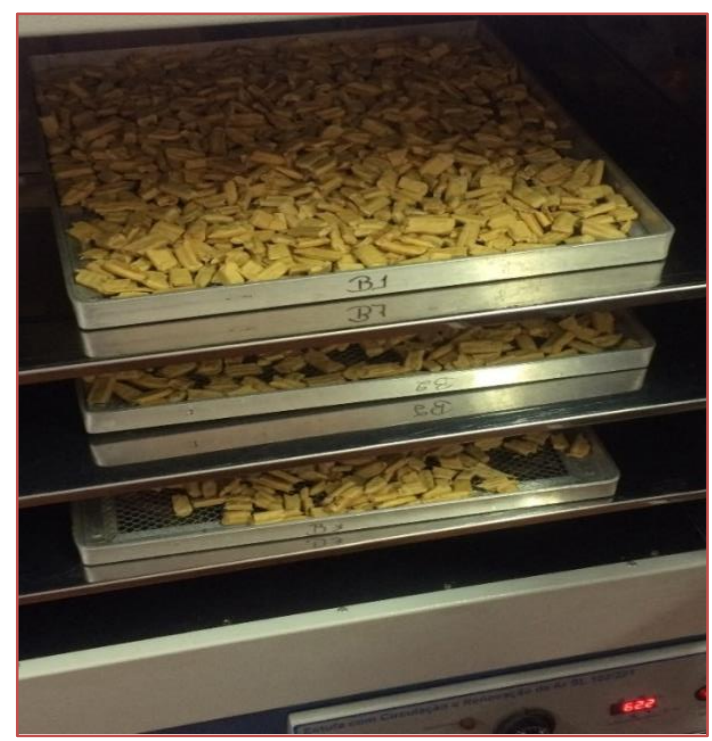

Fonte: Própria autoria (2018).

Para obtenção da farinha de algaroba, o material já seco em cada bandeja foi levado a um tipo de moinho diferente: a) Moinho de Martelo, b) Moinho de Faca e c) moinho de Bolas. Em seguida o produto obtido em cada moinho foi submetido ao peneiramento com um tipo de mesh do tipo Tyler 100.

No Moinho de Martelo, foi colocado o material seco da bandeja B1 diretamente no local onde foi executado a moagem e ao mesmo tempo foi colhido o produto, separado e identificado em uma embalagem plástica bem vedada. Tomou-se bastante cuidado ao manusear o material tendo em vista que ele é bastante higroscópico.

No Moinho de Faca, colocou-se o material da bandeja B2, aos poucos, pois o local de moagem é pequeno e após moer todo o material, foi separado e identificado onde tomou-se as mesmas medidas de precaução contra umidade utilizadas no moinho anterior. 
No Moinho de Bolas, colocou-se uma pequena parte do material da bandeja B3 no recipiente junto com as bolas para a moagem, após ligar o moinho esperou-se cerca de 10 min e recolheu a amostra triturada. Repetiu-se esse processo a batelada até moer todo o material, logo após a moagem foi recolhido e identificado, tomando as devidas precauções.

0 produto de cada moinho ficou cerca de 15 minutos sob peneiramento a 100 mesh, foi separado os subprodutos do mesh onde eles foram identificados referentes a cada tipo de moinho separados do bagaço. 0 produto que não passou pelas peneiras foi levado ao microscópio eletrônico de varredura (MEV).

Para cada mesh de cada moinho foi feita uma foto no MEV nos comprimentos de $2 \mu \mathrm{m}, 10 \mu \mathrm{m}$ e $20 \mu \mathrm{m}$ a fim de ver o perfil morfológico das farinhas obtidos em cada moinho.

As amostras ao serem levadas para o MEV foram revestidas com fio de ouro, pois substâncias que compõem elementos leves como carbono e hidrogênio possuem reflexão fraca e produzem contraste ruim. Por isto usou-se uma baixa voltagem com um fino revestimento de ouro para apresentar condições satisfatórias nas imagens. (SOARES, 2010).

\section{RESULTADOS E DISCUSSÃO}

Com base nos resultados obtidos após a secagem e moagem das amostras de algaroba foi possível observar a diferença em alguns aspectos de forma visual como a cor e a formação de grumos em determinados moinhos.

De acordo com Brasil (1996) a cor das farinhas são devido ao seu conteúdo de carotenóides proteínas, fibras e até mesmo presença de impurezas na moagem. Farinhas destinadas a panificação devem ser preferencialmente claras ou levemente amareladas e sem resíduos de farelos.

Por meio das fotos pode-se observar que a farinha que mais se enquadra neste parâmetro é a farinha moída pelo moinho de bolas, pois possui cor levemente amarelada, poucos grumos quando comparada as demais e é mais fina.

Em um nível de comparativo de cor e quantidade de grumos pode-se dizer que a farinha do moinho de bolas é a melhor, em seguida a do moinho de facas por fim a do moinho de martelos.

Figura 3 - a) Moagem no moinho de bolas, b) Moagem no moinho de martelos e c) Moagem no moinho de facas.

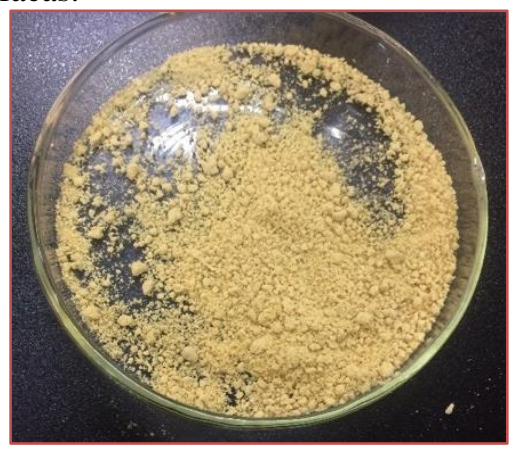

(a)

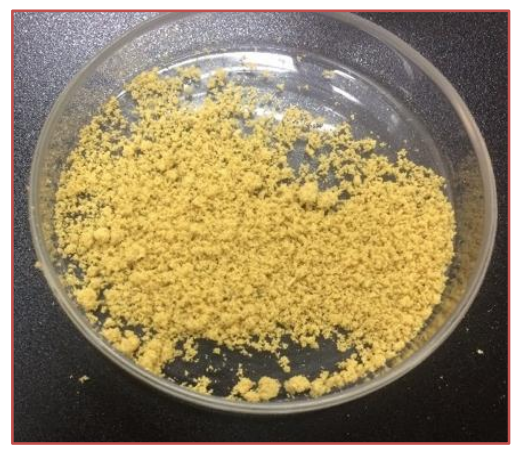

(b)

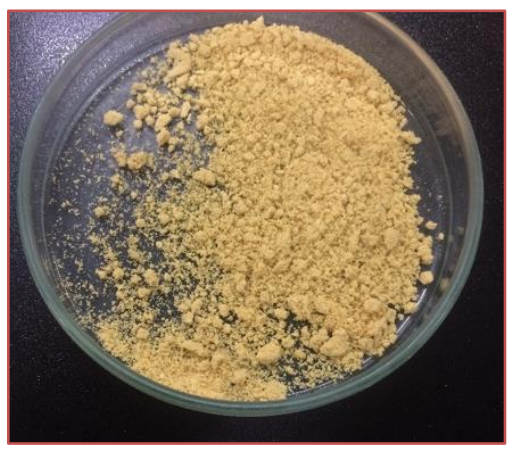

(c)

Fonte: Própria autoria (2018).

Segundo Brasil (1996) em relação a umidade é importante para o processamento da farinha na fabricação de pães, biscoitos, entre outros produtos, já que o ideal é que sua umidade esteja em torno de 13\%, pois farinhas acima desse percentual tentem a formas grumos e prejudicar na elaboração dos produtos a serem fabricados. Esta portaria diz que para farinhas integrais, comum e especial o máximo de umidade é de $15 \%$.

A umidade da farinha de algaroba foi de 14,8 \% então a farinha está dentro dos parâmetros estabelecidos pela portaria. 
Na avaliação das imagens do MEV foram descartados as imagens no comprimento de onda de $2 \mu \mathrm{m}$, pois não ficaram nítidas o bastante para serem avaliadas. As imagens com $10 \mu \mathrm{m}$ e $20 \mu \mathrm{m}$ estão abaixo e correspondem a cada um dos moinhos mencionados.

A maioria das imagens foram as que possuíram aumento de 1000 vezes, pois apresentaram uma maior visualização das características.

Substâncias que possuem elementos mais leves como carbono e hidrogênio

Na Fig. 4, 5 e 6 estão as imagens da algaroba após ser submetida a todos os processos descritos, inclusive o MEV com $10 \mu \mathrm{m}$ e $20 \mu \mathrm{m}$, respectivamente.

É perceptível a existência de aglomerados em forma arredondada de partículas, porém elas não foram totalmente sintetizadas já que ainda existem espaços entre os grumos, além de evidenciar uma característica porosa na substância (BORLINI, 2005).

A Fig. 4 a) remete a sensação de que os aglomerados são menores dando um aspecto irregular enquanto a imagem b) com $20 \mu \mathrm{m}$ pelo possível aumento do diâmetro o aspecto irregular é minimizado (BARBOSA, 2012).

Figura 4 - a) MEV do moinho de bolas a $10 \mu \mathrm{m}$ e b) MEV do moinho de bolas a $20 \mu \mathrm{m}$.
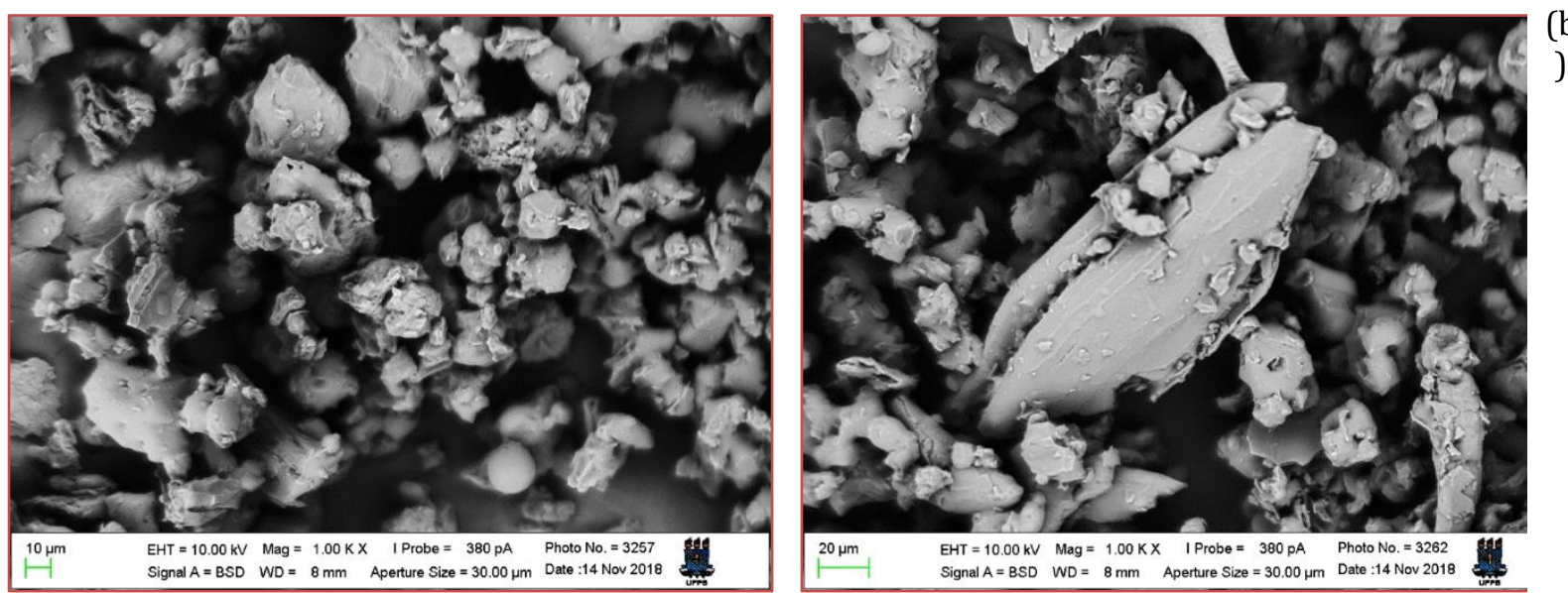

(a)

Fonte: Própria autoria (2018).

Enquanto na Fig. 5 referente ao moinho de martelos mostra-se aglomerados muito maiores em relação a Fig. 4 do moinho de bolas, além possuir porosidade e irregularidade muito maior em relação as imagens do moinho anterior, que não é desejável para o produto.

Figura 5 - a) MEV do moinho de martelos a $10 \mu \mathrm{m}$ e b) MEV do moinho de martelos a $20 \mu \mathrm{m}$.

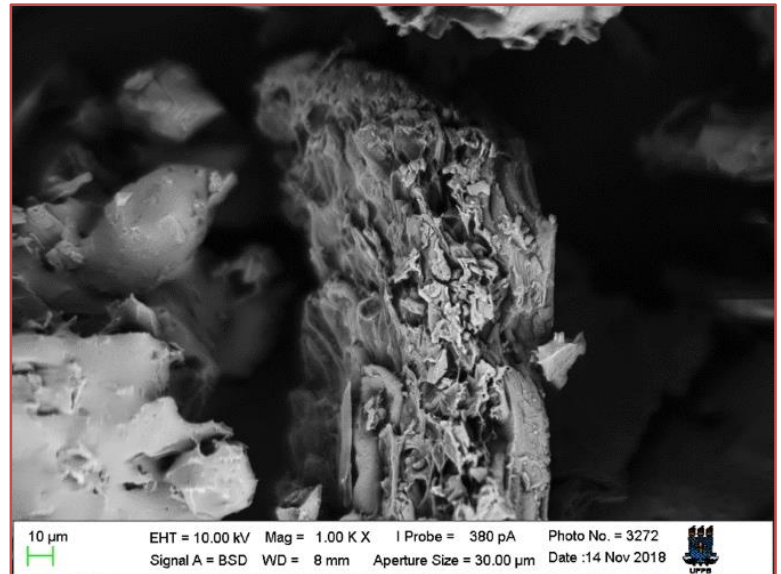

(a)

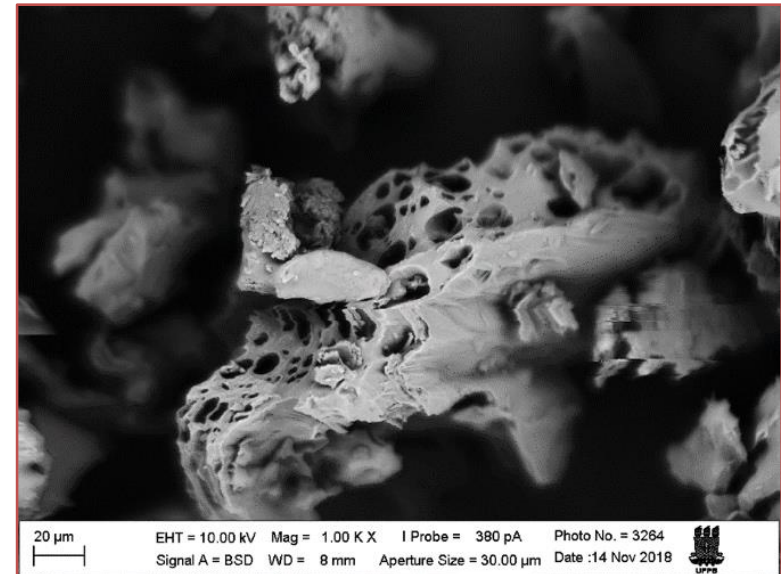

(b)

Fonte: Própria autoria (2018). 
Na Fig. 6 b) por motivos técnicos do equipamento não foi possível capturar a imagem com o aumento de 1000 vezes por isso a ilustração aparece mais distante em relação as outras, mas isso não ocorrerá o impedimento de sua análise.

Ambas imagens mostram ser bastante porosas o que não é o ideal para a farinha, além de apresentar grumos grandes, está característica da presença de grumos pode ser devido a algaroba ser higróscopica e ao longo das análises adquiriu mais o umidade do que o previsto.

Figura 6 - a) MEV do moinho de facas a $10 \mu \mathrm{m}$ e b) MEV do moinho de facas a $20 \mu \mathrm{m}$.

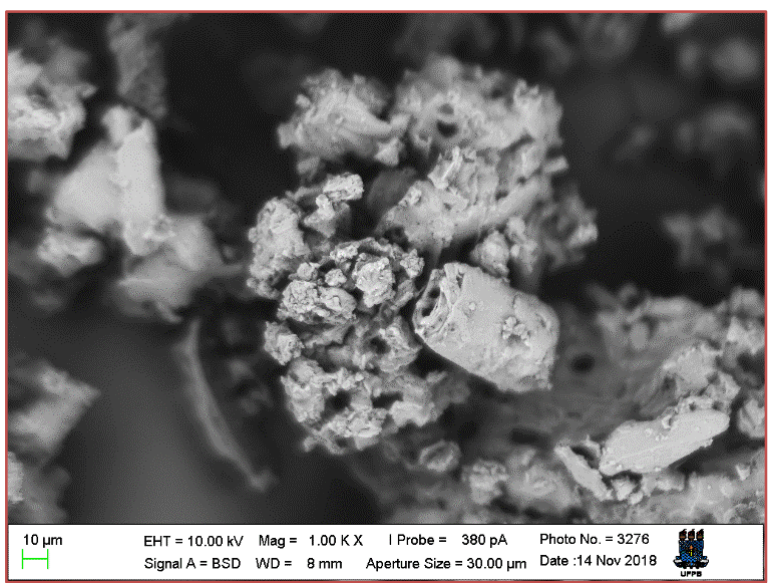

(a)

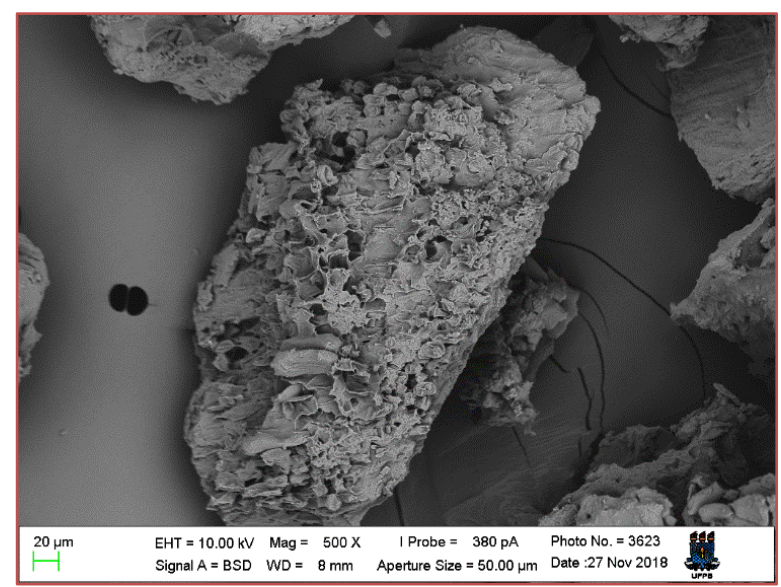

(b)

Fonte: Própria autoria (2018).

\section{CONSIDERAÇÕES FINAIS}

Sobre os resultados podemos concluir que apesar da cor das farinhas para fabricação de bolos, pães e massas serem mais claras as especificações da farinha de algaroba relacionada a cor levemente amarelada não seria um problema para a elaboração deste produtos já que este padrão de cor é aceitável.

Já a umidade da farinha foi considerada dentro do padrão estabelecido, porém para quantificá-la como boa em fabricação de pães e bolos outros fatores devem ser levados em consideração.

Com as imagens do MEV identificou-se algumas características morfológicas da algaroba em cada um dos moinhos. No moinho de bolas foi onde a farinha da algaroba se comportou melhor, seguido do moinho de facas e por fim o moinho de martelos. No moinho de bolas as imagens apresentaram-se com menos grumos, menor porosidade e menos irregularidades.

\section{REFERÊNCIAS}

[1] BARBOSA, A. A. S. Desenvolvimento de argamassas de revestimento com adição concomitante de cinzas de lenha e lodo têxtil gerados no APL confecções Pernambucano. Trabalho de Conclusão de Curso (Graduação em Engenharia Civil) - Universidade Federal de Pernambuco. Caruaru, 2012

[2] BORLINI, M. C. Cinza da lenha para aplicação em cerâmica vermelha. parte I: características da cinza. Cerâmica [online]. 2005, vol.51, n.319 [cited 2009-04-27], pp. 192- 196.Availablefrom:. ISSN 0366-6913. doi: 10.1590/S0366- 69132005000300004.

[3] BRASIL. Ministério da Saúde. Portaria DETEN n 354, de 18 de julho de 1996. Aprova a Norma Técnica referente a Farinha de Trigo. Diário Oficial da União, Brasília, de 22 de julho de 1996, Seção 1, pt. 1.

[4] CARIOCA, J.O.B.; ALMEIDA, M. F. L.; SEIDL, P. R.; Química verde no Brasil: 2010-2030. Brasília, DF: Centro de Gestão e Estudos Estratégicos, 2010.

[5] CARRISSO, R.C.C.; CORREIRA, J.C.G. Tratamento de minérios: Classificação e Peneiramento. 4⿳a Edição. Rio de Janeiro: CETEM, 2004.

[6] CELESTINO, S.M.C. Princípios de secagem de alimentos. 1a Edição. Planaltina, DF: Embrapa Cerrados, 2010. 
[7] DEDAVID, B.A.; GOMES, C.I.; MACHADO, G. Microscopia eletrônica de varredura aplicações e preparação de amostras: Materiais poliméricos, metálicos e semicondutores. Porto Alegre: EDIPUCRS, 2007.

[8] DONG, H.; STRAWHECKER, K.E.; SNYDER, J.F.; ORLICKI, J. A.; REINER, R.S.; RUDIER, A.W. Cellulose nanocrystals as a reinforcing material for electrospun poly(methyl methacrylate) fibers: Formation, properties and nanomechanical characterization. Carbohydrate Polymers, v. 87, p. 2488- 2495, 2012.

[9] PEREZ, S.C.J.A.; MORAES, J.A.P. V. Influência do estresse híbrico e do pH no processo germinativo da algarobeira. Pesquisa Agropecuária Brasileira, Brasília, v. 26, n. 7, p. 981-988, 1991.

[10] REED, S.J.B. Electron Microprobe Analysis and Scanning Electron Microscopyin Geology. New York, Cambridge University Press. 201 p. 1996.

[11] SAWYER, L.C.; GRUBB, D.T. Polymer Microscopy. 2ª Ed. Londres: Champman \& Hall, 1996. 399 p.

[12] SILVA, C.G. Extração e Fermentação do Caldo de Algaroba (Prosopis juliflora (Sw) DC) para obtenção de aguardente. Revista Brasileira de Produtos Agroindustriais, Campina Grande, v. 5, n. 1, p. 51-56, 2003.

[13] SILVA, S.A. Estudo termogravimétrico e calorimétrico da algaroba. Química Nova, São Paulo, v. 24, n. 4, p. 460-464, 2001.

[14] Soares, B.M.C.; SARON, E.S. Microanálise elementar de materiais: aplicações do sistema MEV-EDX. Instituto de Tecnologia de Alimentos, Rio de Janeiro. v.22, n. 1, jan-mar, 2010.

[15] VIEIRA, R.L.; GUERRA, N.B.; FREITAS, E.M. Sucedâneo do Café a partir de Prosopis juliflora D.C. Pesquisa Agropecuária Brasileira, Brasília, v. 30, n. 1, p. 121-124, jan., 1995. 


\section{Capítulo 18}

\section{Otimização da extração mecânica do Óleo de Nim utilizando metodologia de superfíce de resposta}

\section{Evely Degraf Terra Parckert \\ José Roberto Delalibera Finzer}

Resumo: As técnicas de extração de óleo, com finalidades terapêuticas, têm sido objeto de inúmeras pesquisas que buscam, além de melhores rendimentos, maiores concentrações dos princípios ativos. Dentro deste contexto, a prensagem tem se destacado entre os estudos envolvendo sementes oleaginosas. No presente trabalho, avaliou-se, através da metodologia de superfície de resposta, a influência da taxa de alimentação de sementes, da velocidade de rotação do eixo do extrusor e da temperatura do ar de secagem das sementes na eficiência de extração, na concentração de azadiractina A e na umidade do óleo extraído. A condição otimizada, em função das variáveis reais, foram $2,4 \mathrm{~kg} / \mathrm{h}, 64,14 \mathrm{rpm}$ e $54,34{ }^{\circ} \mathrm{C}$ para a taxa de alimentação, velocidade de rotação do eixo e temperatura de secagem das sementes, respectivamente. 0 modelo testado prevê uma eficiência de extração de 66,13\%, umidade do óleo de Nim de 0,017 kgágua/kgóleoseco e concentração de azadiractina A de 596,54 ppm.

Palavras-chave: Nim; extração de óleo; caracterização 


\section{INTRODUÇÃO}

A árvore Nim (Azadirachta indica), natural do sudeste da Ásia e do subcontinente indiano, é utilizada há séculos, em sua região de origem, na medicina humana e animal, na agricultura, pecuária e em sistemas de reflorestamento. Apresenta como princípio ativo mais importante a azadiractina, concentrada nos frutos. Das sementes se extraem o óleo e a torta cujo rendimento e qualidade são fortemente dependentes das condições de processamento.

Embora muitas plantas sejam citadas na literatura, o Nim, tem sido uma das árvores com maior número de benefícios relatados. Sua utilização na medicina humana e animal, indústria, agricultura e pecuária tem sido objeto de estudos científicos que buscam fornecer informações relativas à produção, colheita, práticas pós-colheita e formas de uso dos derivados da planta.

É uma árvore com imenso potencial se relacionado à proteção do meio ambiente e desenvolvimento sustentável da agricultura nacional. Tem sido amplamente empregada na agricultura orgânica, no controle de pragas residenciais, na pecuária e na veterinária e como planta medicinal. Em países da Ásia e Europa já existem medicamentos no mercado, para uso do Nim como adstringente, antipirético, diurético, sedativo, purgativo, tônicos, entre outros. Derivados da planta encontram-se também incorporados em numerosos produtos farmacêuticos.

Considerando a multiplicidade de aplicação do Nim e seus derivados, o presente trabalho consistiu em avaliar a influência de variáveis do processo de extração do óleo na eficiência, concentração de azadiractina $\mathrm{A}$ e umidade do produto obtido, sendo indicado um modelo que garanta maior eficiência e concentração de azadiractina A e menor umidade para o óleo extraído.

\section{MATERIAL E MÉTODOS}

\subsection{PREPARO DAS AMOSTRAS}

O processamento de frutos de Nim, visando à obtenção das sementes, compreende a colheita; classificação; seleção; despolpagem; lavagem e secagem. Os frutos de Nim, dispostos em cachos, foram colhidos manualmente selecionando os que apresentavam pelo menos um quarto de frutos maduros, identificados pela coloração amarela. Esse estágio de maturação corresponde ao estágio E do índice de cores ilustrado na Figura 1.

Após a colheita, os frutos foram classificados, quanto ao estágio de maturação, e selecionados, quanto à sua integridade, optando-se pelos maduros e com menor deformação. Após esta etapa, foram despolpados manualmente, pressionando-os levemente, em movimentos circulares, sob uma peneira. A Figura 2 ilustra: (A) os frutos e (B) as sementes de Nim, ver na Figura 2, as sementes despolpadas.

Figura 1 - Estágios de maturação relacionados à cor da casca dos frutos de Nim: A verde escuro; B verde claro; C verde claro com tendência a amarelo; D mais amarelo que verde; E completamente amarelo.

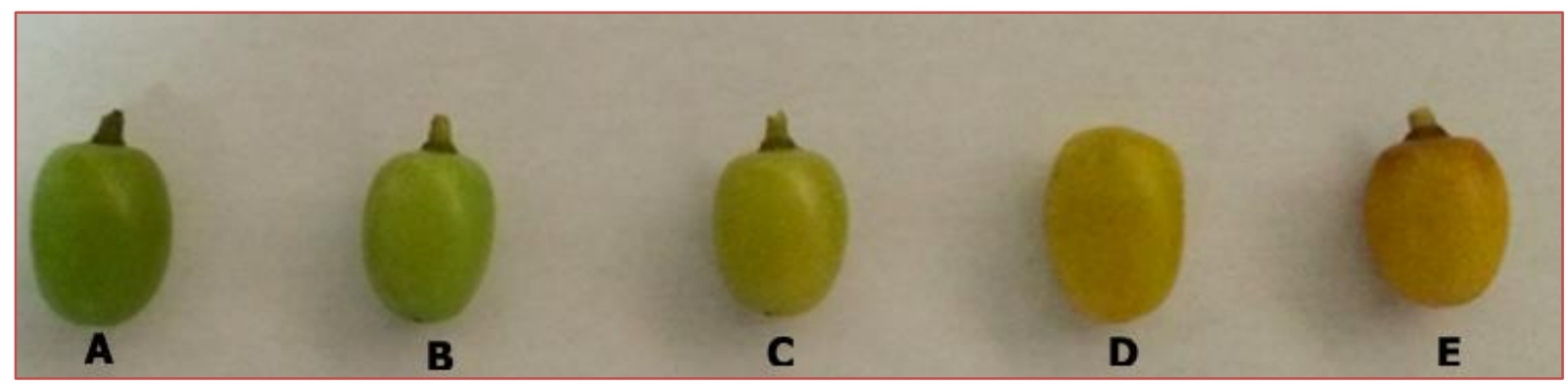

A massa de sementes obtida foi de aproximadamente 36\% da massa inicial de frutos. Após a despolpagem e lavagem com água corrente, as sementes foram submetidas à secagem em desidratador de bandejas, visando adequá-las à etapa de extração do óleo.

A umidade desejada ao final da secagem deve estar compreendida entre 7 e $9 \%$, o que consiste em um parâmetro descrito pelo fabricante da prensa, a ser utilizada para extração do óleo de Nim (ECIRTEC, 2012). 
Para realização dos ensaios, a massa de sementes de Nim foi distribuída nas bandejas do desidratador. As bandejas tiveram toda a superfície coberta pelas sementes, em camada fina, sendo a massa de sementes de aproximadamente $2000 \mathrm{~g}$ por bandeja.

0 tempo total de processamento, considerando as temperaturas de 40,50, 60 e $70^{\circ} \mathrm{C}$, foi em torno de $18 \mathrm{~h}$, $14 \mathrm{~h}, 12 \mathrm{~h}$ e $5 \mathrm{~h}$, respectivamente. Após este período as sementes, utilizadas em todos os experimentos, atingiram um conteúdo final de umidade de 0,09 kgágua/kgsemente seca.

Figura 2 - Nim. A) frutos, B) sementes.

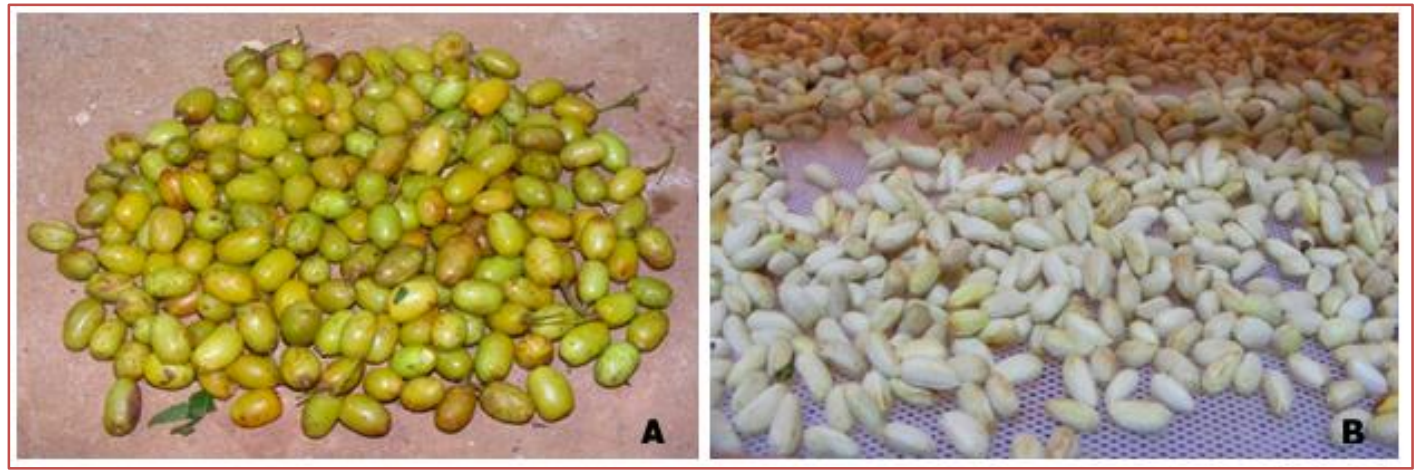

\subsection{PROCEDIMENTO EXPERIMENTAL}

O equipamento utilizado nos ensaios experimentais é mostrado na Figura 3. A mini prensa, marca Ecirtec, modelo MPE - 40AC, construída em aço carbono é formada por: moega de alimentação, cárter alimentador, cesto de compressão contendo doze discos em aço carbono, cone de saída, bandeja coletora e eixo helicoidal com diâmetro nominal de $60 \mathrm{~mm}$, apoiado em mancal com rolamentos e bucha de bronze. Possui sistema de acionamento formado por moto redutor SEW, com capacidade de $5 \mathrm{cv}$, operando à $220 \mathrm{~V}$.

Figura 3 - Vista da prensa utilizada para extração do óleo de Nim.

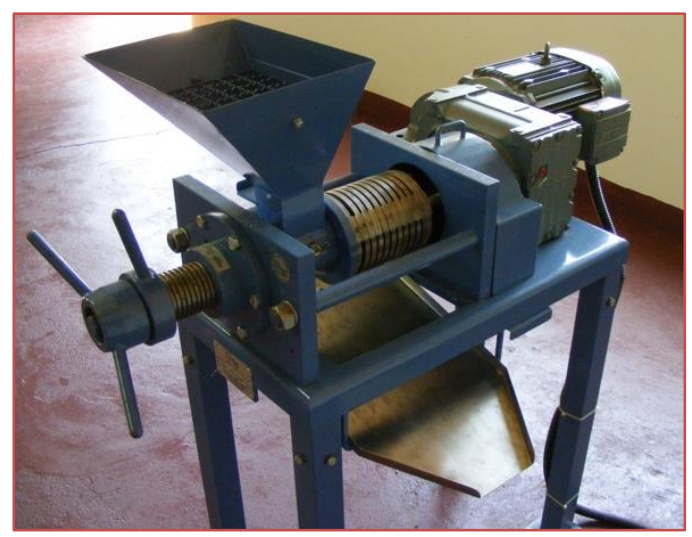

Realizou-se um planejamento experimental visando detectar condições operacionais que otimizassem o processo de extração do óleo de Nim, com a utilização de mini prensa, visando obtenção de maior rendimento e concentração de princípio ativo e menor conteúdo de umidade para o óleo obtido.

Para análise da extração do óleo de Nim, realizou-se um planejamento composto central, com quatro repetições na região central e seis ensaios nos pontos axiais $(\alpha)$, totalizando dezoito ensaios. Com as respostas obtidas e, adotando um nível de significância p de 10\%, foram calculados os efeitos principais e os de interação entre variáveis, sendo possível avaliar quais foram as variáveis significativas no processo de extração de óleo de Nim para a faixa estudada. 
As variáveis independentes empregadas foram: taxa de alimentação de sementes $(\mathrm{kg} / \mathrm{h})$, velocidade de rotação do eixo do extrusor (rpm) e temperatura do ar de secagem das sementes $\left({ }^{\circ} \mathrm{C}\right)$.

A Tabela 1 apresenta os níveis utilizados para as variáveis independentes e seus respectivos intervalos. 0 valor utilizado para os níveis extremos deste planejamento foi gerado pelo software Statistica 7.0, sendo de 1,414 .

Tabela 1 - Valores utilizados no PCC para três variáveis

\begin{tabular}{|l|c|c|c|c|c|c|}
\multicolumn{1}{|c}{ Variáveis Reais } & $\begin{array}{c}\text { Variáveis } \\
\text { Codificadas }\end{array}$ & $-1,414$ & -1 & 0 & +1 & $+1,414$ \\
\hline Taxa de alimentação de sementes $(\mathrm{kg} / \mathrm{h})$ & $\mathrm{x} 1$ & 1,59 & 2 & 3 & 4 & 4,41 \\
\hline Velocidade de rotação do eixo $(\mathrm{rpm})$ & $\mathrm{x} 2$ & 35,86 & 40 & 50 & 60 & 64,14 \\
\hline Temperatura do ar de secagem $\left({ }^{\circ} \mathrm{C}\right)$ & $\mathrm{x} 3$ & 45,86 & 50 & 60 & 70 & 74,14 \\
\hline
\end{tabular}

Testes preliminares mostraram que a taxa de alimentação máxima de sementes consistia em $4 \mathrm{~kg} / \mathrm{h}$.

As respostas analisadas (y) foram: eficiência de extração (\%), concentração de azadiractina A (ppm) e umidade do óleo extraído (kgágua/kgóleoseco).

0 conteúdo de óleo presente nas sementes foi quantificado utilizando o solvente hexano em extrator Soxhlet, obteve-se 35,2\% em massa de óleo.

Para a análise de umidade do óleo extraído, utilizou-se o método descrito por AOAC (1996). A amostra deve ser aquecida em estufa a vácuo, onde se reduz a pressão e se mantém a temperatura de $70^{\circ} \mathrm{C} .0$ método considera perda por dessecação até massa constante.

A avaliação da concentração de azadiractina A, foi realizada por cromatografia líquida de alta eficiência através da utilização do cromatógrafo Agilent Tecnologies 1200 series, com detector de arranjo de diodos (HPLC-DAD), coluna de fase reversa C18 de $10 \mathrm{~cm}$, fase móvel acetonitrila/água 40:60 com vazão de 1 $\mathrm{mL} / \mathrm{min}$ e comprimento de onda de $217 \mathrm{~nm}$ (YAMASAKI et al., 1986). Para as análises foi utilizado o padrão analítico de azadiractina, marca Supelco, comercializado pela Sigma - Aldrich Brasil Ltda com $99,5 \%$ de pureza.

\section{RESULTADOS E DISCUSSÃO}

Os resultados apresentados indicam que a taxa de alimentação de sementes, a velocidade de rotação do eixo e a temperatura do ar de secagem mostraram-se significativos sobre a eficiência de extração, assim como, o efeito de interação entre a taxa de alimentação e a temperatura do ar de secagem. Em todos os casos os níveis p observados foram inferiores ao estipulado (10\%).

Para a resposta umidade do óleo, foram consideradas significativas a velocidade de rotação do eixo e a temperatura de secagem das sementes. A interação entre as variáveis independentes não demonstrou nível de significância para os valores experimentais estudados.

Considerando a concentração de azadiractina A, o resultado indica que as variáveis taxa de alimentação, velocidade de rotação do eixo do extrusor e temperatura de secagem das sementes são significativas ao processo.

A partir da análise das superfícies de respostas geradas para a eficiência de extração, mostradas pela Figura 4, verifica-se que ocorre um aumento considerável na eficiência de extração quando se aumenta a velocidade de rotação do eixo. Pode-se observar ainda a influência significativa da temperatura de secagem das sementes de Nim na eficiência de extração variando-se a taxa de alimentação de sementes e a velocidade de rotação do eixo.

A mesma análise pode ser inferida para a taxa de alimentação. 0 aumento da temperatura do ar de secagem diminui a umidade do óleo, o que é desejável para o processo.

Um aumento na umidade do óleo de Nim com a diminuição da temperatura do ar de secagem também foi constatado. Com a diminuição da velocidade de rotação do eixo ocorreu a diminuição do conteúdo de umidade do óleo, conforme mostra Figura 5. 
Figura 4 - Superfícies de resposta para eficiência de extração com relação às variáveis dependentes
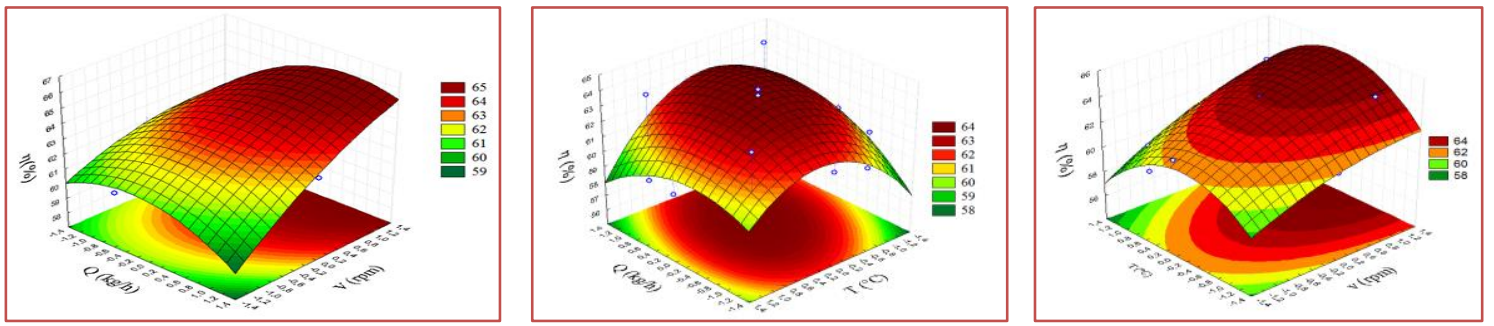

Figura 5 - Superfícies de resposta para umidade do óleo em relação às variáveis dependentes
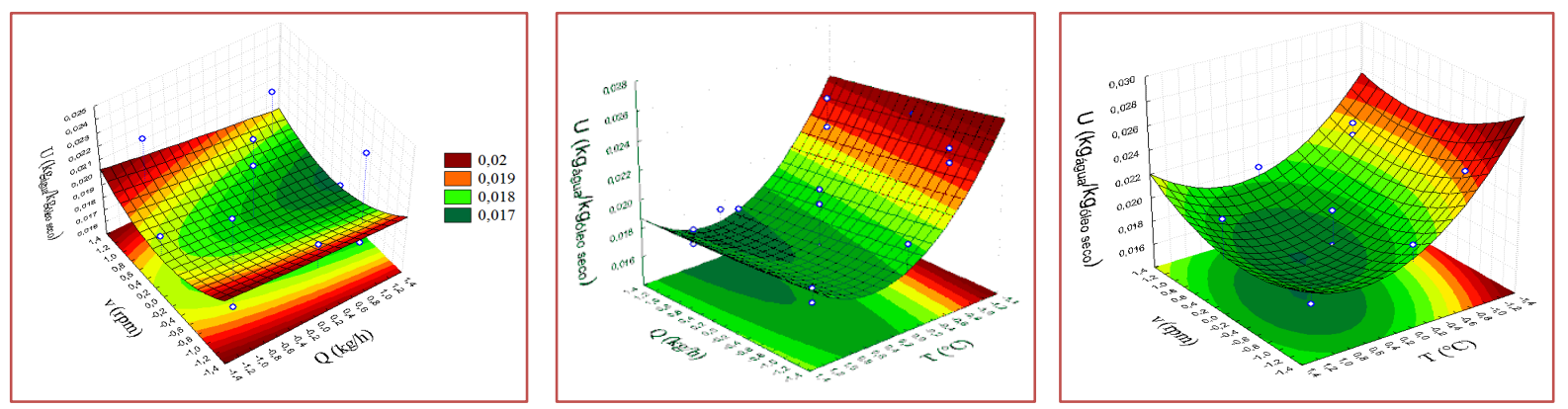

Para a concentração de azadiractina A, de acordo com os resultados demonstrados na Figura 6, percebe-se o maior efeito da velocidade de rotação do eixo do que o da vazão de alimentação de sementes. Para uma mesma vazão de alimentação, a concentração de azadiractina A tende a aumentar quando a velocidade de rotação do eixo diminui. Este comportamento pode ser explicado pelo fato de que a uma maior velocidade de rotação do eixo, observa-se maior taxa de cisalhamento, o que devido ao aumento de temperatura do material, pode comprometer o teor de princípio ativo.

Verifica-se que ocorre um aumento na concentração de azadiractina A quando se diminui a velocidade de rotação do eixo, principalmente para menores taxas de alimentação de sementes, sendo este efeito mais brando para taxas maiores.

Figura 6 - Superfícies de resposta para a concentração de azadiractina A em relação às variáveis dependentes
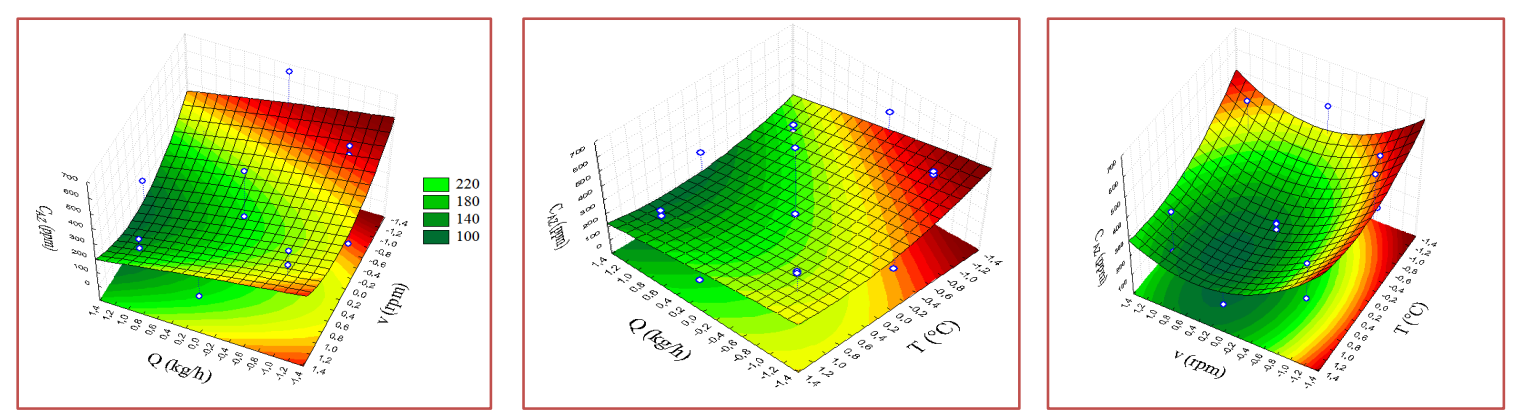

Constatou-se um aumento na concentração de azadiractina A com a diminuição da temperatura do ar de secagem, principalmente para baixos valores da taxa de alimentação. A taxa de alimentação provoca respostas significativas na concentração de azadiractina A, principalmente em altos valores da temperatura de secagem das sementes, onde a diminuição da taxa de alimentação provoca um aumento da concentração do princípio ativo.

Utilizando o modelo proposto, foram obtidos, no software Statistica 7.0, os valores das variáveis codificadas que proporcionavam uma resposta máxima para a eficiência de extração e concentração de azadiractina A que em função das variáveis reais foram $Q=2,4 \mathrm{~kg}$; v = 64,14 rpm e T = 54,34 ${ }^{\circ} \mathrm{C}$. 
O modelo, testado para a condição otimizada, prevê uma eficiência de extração de 66,13\%, umidade do óleo de Nim de 0,017 kgágua/kgóleo seco e concentração de azadiractina A de 596,54ppm.

Após a realização de teste experimental, utilizando as variáveis reais da condição otimizada, foram apresentados valores aproximados para a eficiência de extração, umidade do óleo de Nim e concentração de azadiractina A, sendo de 62,9\%; 0,018 kgágua/kgóleo seco e 590,23, respectivamente. 0 resultado confirma os valores encontrados para as variáveis na condição otimizada.

\section{CONCLUSÕES}

0 aumento da velocidade de rotação do eixo provoca um aumento na eficiência de extração. Para altos valores da velocidade de rotação do eixo, a resposta é influenciada pela taxa de alimentação. A eficiência de extração também foi influenciada pela temperatura de secagem das sementes variando-se a taxa de alimentação e a velocidade de rotação do eixo.

Para a resposta umidade do óleo, a taxa de alimentação de sementes não apresenta influência significativa. Valores extremos da velocidade de rotação do eixo provocam um aumento para esta resposta enquanto que maiores valores da temperatura do ar de secagem diminuem a umidade do óleo.

0 aumento da temperatura de secagem das sementes e valores médios da velocidade de rotação do eixo diminuem a concentração de azadiractina A. 0 aumento para esta resposta foi observado a partir da diminuição da velocidade de rotação do eixo para menores valores da taxa de alimentação de semente.

A condição otimizada em função das variáveis reais foram $2,4 \mathrm{~kg} / \mathrm{h}, 64,14 \mathrm{rpm}$ e $54,34{ }^{\circ} \mathrm{C}$ para a taxa de alimentação, velocidade de rotação do eixo e temperatura de secagem das sementes. 0 modelo, testado para a condição otimizada, prevê uma eficiência de extração de 66,13\%, umidade do óleo de Nim de 0,017 kgágua/kgóleoseco e concentração de azadiractina A de 596,54 ppm.

Com o aumento da taxa de alimentação de sementes observou-se diminuição da variação de pressão exercida sob as partículas durante a compressão.

\section{AGRADECIMENTOS}

À Fundação de Amparo à Pesquisa do Estado de Minas Gerais - FAPEMIG pelo incentivo financeiro.

\section{REFERÊNCIAS}

[1] ASSOCIATION OF OFFICIAL ANALYTICAL CHEMISTS. Official methods of analysis of the Association of Official Analytical Chemists (method 926.12). Arlington: A.O.A.C., chapter 33, p. 5, 1996.

[2] ECIRTEC EQUIPAMENTOS E ACESSÓRIOS INDUSTRIAIS LTDA. Orientações. [Mensagem pessoal]. Mensagem recebida por <evelyterra@yahoo.com.br> em 13 jan. 2012.

[3] YAMASAKI, R. B.; KLOCKE J. A.; LEE, S. M.; STONE, G. A. E DARLINGTON, M. V. Isolation and Purification of azadirachtin from neem (Azadirachta indica) seeds using flash chromatography and high-performance liquid chromatography. Journal of Chromatography, v.356, p.220-226, 1986. 


\section{Capítulo 19}

\section{Avaliação das condições higiênico-sanitárias em panificadoras da região sul do munícipio de Palmas- TO}

\section{Maykon Jhuly Martins de Paiva \\ Iangla Araújo de Melo Damasceno \\ Eduardo Sousa dos Anjos}

Resumo: A população está cada vez mais à procura de alimentos prontos, tendo em vista a praticidade e a variedade oferecida. 0 setor de panificação é um dos que mais cresce no Brasil, e essa expansão traz preocupação principalmente aos serviços de saúde pública, isso porque ainda existe um alto índice de doenças transmitidas por alimentos. Assim o objetivo deste trabalho foi avaliar as condições higiênico-sanitárias de panificadoras da região sul do município de Palmas-TO. Foram utilizadas fichas de verificação (check-list), que foram montadas de acordo com a RDC. $\mathrm{n} \cong 275$ e RDC. nํ 216 da ANVISA. Os resultados revelaram importantes irregularidades nos 4 estabelecimentos visitados. Sendo a panificadora A, a com o maior número de irregularidades. Diante disso é possível afirmar que se faz necessário uma maior atenção com os produtos preparados e comercializados por essas panificadoras, realizando adequação e implantação de boas práticas de manipulação de alimentos.

Palavras-chave: Saúde pública; Segurança alimentar; Panificação; Higiene 


\section{INTRODUÇÃO}

Apesar da alta expansão do número de empresas e indústrias de panificação no Brasil, ainda é alto o índice de infestação e contaminação nesses ambientes produtores de alimentos. São definidas as padarias ou panificadoras, as empresas que vendem e produzem produtos de panificação e confeitaria, hoje fabricando bem mais que pães e biscoitos, sendo assim capaz e com condições de produzir muitos alimentos e estes quando atingem uma qualidade satisfatória podem incrementar as vendas no comércio, atendendo as necessidades do consumidor e gerando emprego e renda (CASARIL, et al., 2016)

O setor de panificação está entre os maiores segmentos da área indústria do Brasil, de acordo com o Programa de Desenvolvimento, da Alimentação Confeitaria e Panificação (PROPAN), são mais de 63 mil pequenas empresas que atendem uma população média de quase 42 milhões de clientes todos os dias (PROPAN, 2014).

Com o crescimento populacional, as pessoas sempre buscam as formas mais práticas de se alimentar. No Brasil, existe também uma busca constante por preços mais acessíveis, o que muitas vezes pode ocasionar uma série de problemas de saúde pública, principalmente a intoxicação alimentar, isso porque muitos alimentos são preparados em locais inadequados não atendendo as exigências para a boa prática de manipulação de alimentos (CARDOSO, et al., 2011).

Quando se fala em qualidade de um alimento para o consumidor atual, que está cada vez mais exigente, não se considera apenas as características de sabor, aroma, aparência, textura e padronização, mas também existe uma importante preocupação em adquirir alimentos que não tragam ao organismo problemas de saúde e que além de alimentar, proporcione bem estar (CARDOSO e ARAÚJO, 2001).

É frequente encontrar nesses locais o maior índice de problemas no setor de produção, principalmente com relação às condições higiênico-sanitárias, além de equipamentos e utensílios com péssimas condições de uso e manipuladores sem treinamento adequado (OLIVEIRA, et al., 2016).

Diante do aumento considerável da procura por produtos alimentícios produzidos em panificadoras e padarias e o alto índice de doenças provocadas por alimentos contaminados, além do não seguimento das boas praticas de manipulação de alimentos por empresas desse ramo, esse trabalho teve como objetivo avaliar as condições higiênico-sanitárias de 4 estabelecimentos localizados na região sul de Palmas-TO.

\section{MATERIAL E METÓDOS}

Este trabalho foi realizado em quatro padarias/panificadoras, classificadas como comerciais, assim receberam a referência de A, B, C e D, todas localizadas no município de Palmas-TO. A coleta de dados ocorreu no período de 20 de dezembro de 2017 a 05 de fevereiro de 2018. Para avaliar as condições higiênico-sanitárias foi utilizada uma ficha de verificação (chek list) tendo como base a RDC 275 e 216 da Agência Nacional de Vigilância Sanitária (ANVISA), foram selecionados 40 itens de verificação que englobam os seguintes blocos: higiene das instalações, equipamentos e utensílios, equipamentos móveis, utensílios e maquinários, condições de conduta e higiene pessoal dos manipuladores e produção e transporte de alimentos. Para avaliar a adequação dos locais, foram criados 3 grupos, sendo: Grupo I: bom/ótimo (76 a 100\% dos itens esperados) , Grupo II: regular (50 a 75\% dos itens esperados), Grupo III: ruim/péssimo(0 a 50\% dos itens esperados).

\section{RESULTADOS E DISCUSSÃO}

De acordo com os dados obtidos foi possível analisar que quase todas as panificadoras apresentaram índices insatisfatórios nos quesitos analisados. A panificadora D foi que a teve o maior índice de aprovação em todas as classificações quando se compara as outras verificadas. Os índices classificados em porcentagens para higienização dos manipuladores e conduta pessoal (85\%), equipamentos moveis, utensílios, maquinários (90\%) e higienização e manutenção de instalações (79\%), e produção e transporte dos alimentos (83\%), faz com que a mesma seja enquadrada na classificação do Grupo I, o mesmo corresponde ao conceito: bom ótimo (76 a 100\% dos itens esperados).

A panificadora $\mathrm{A}$, foi a que teve a menor classificação não se enquadrando em nenhum dos itens analisados, como regular, bom/ótimo, sendo assim classificada no Grupo III: ruim/péssimo (0 a 50\% dos itens esperados) para todos os blocos de classificação. Oliveira, et al., (2016), encontrou resultados semelhantes ao realizar o trabalho: Condições higiênico-sanitárias de unidades produtoras de refeições 
comerciais localizadas no entorno da Universidade Federal de Sergipe, onde alguns estabelecimentos apresentaram níveis de classificação bem abaixo do preconizado pela legislação.

Guimarães \& Figueiredo (2010) ao fazer a avaliação das condições higiênico-sanitárias de panificadoras localizadas no município de Santa Maria do Pará-PA, conseguiram resultados demostrando que as três panificadoras avaliadas apresentaram elevado grau de não conformidades, não possuindo condições higiênico-sanitárias satisfatórias, desse modo ficando em desacordo com o programa de qualidade Boas Práticas de Fabricação - BPF.

Conforme pode ser analisado na Figura 1, a panificadora C, apresentou resultados satisfatórios para os quesitos: produção e transporte de alimentos (80\%) e higiene e conduta dos manipuladores (88\%) ficando no grupo I, mas não atendeu as classificações: higiene das instalações, equipamentos e utensílios (48\%) e equipamentos móveis e utensílios (33\%) o fato se deve principalmente aos mesmos estarem com características de muito tempo de uso com presença de ferrugem e com pequenas avarias que podem comprometer a qualidade higiênico-sanitária dos alimentos.

Com a classificação no grupo II em todos os quesitos a panificadora B, apresentou características que permitiram em um contexto geral ser classificada em regular (50 a 75\% dos itens esperados).

Figura - 1 Ilustração das médias obtidas em cada panificadora avaliada em \%

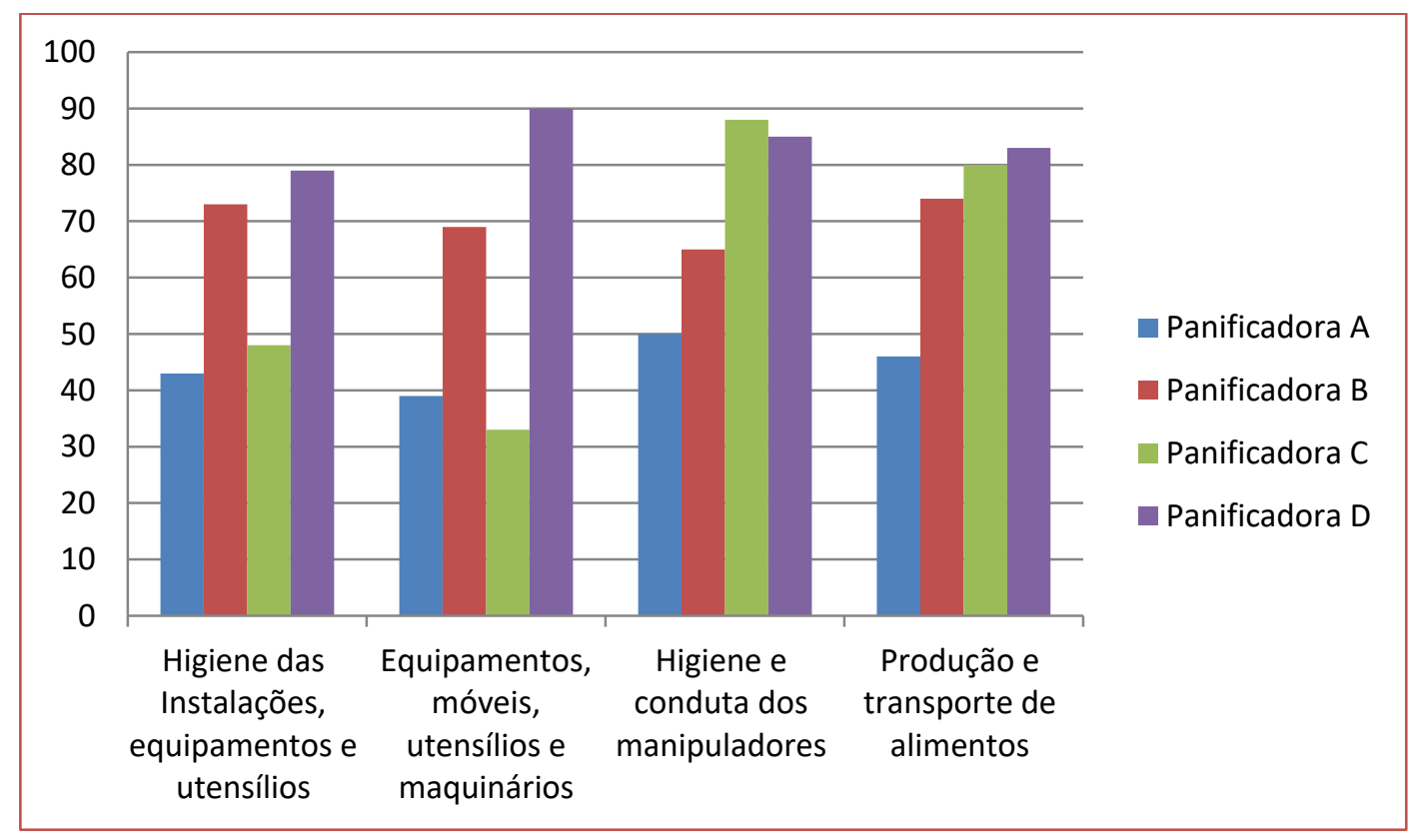

Fonte: Autores

Quando se comparou as condições estruturais as paredes da área de produção da Panificadora C encontravam-se pintadas, mas com presença de mofo. Para atender as exigências se faz necessário que as paredes recebam um revestimento com materiais impermeáveis, que possam ser laváveis, de cores claras, lisas e sem frestas.

\section{CONCLUSÕES}

Diante dos dados coletados e após fazer a análise dos resultados obtidos que foram elucidados através da lista de verificação é possível concluir que apenas uma das quatro panificadoras avaliadas apresentou condições satisfatória na produção de alimentos, as demais ainda tem um elevado grau de não conformidade, não oferecendo aos seus consumidores condições higiênico-sanitárias suficientes, ou satisfatórias. Faz-se necessário uma revisão e adequação para ficarem em acordo com o programa de qualidade de Boas Práticas de Fabricação, garantindo assim alimentos seguros e saudáveis. 


\section{REFERÊNCIAS}

[1] Casaril, K. B. P. B.; Abreu, A. S. (2016). Verificação das condições higiênico-sanitárias de panificadoras em Francisco Beltrão, PR. Revista brasileira de Tecnologia Agroindustrial, 10 (2), 31-40.

[2] Cardoso, L.; Araújo, W. M. C. (2001). Perfil higiênico-sanitário das panificadoras do Distrito Federal. Revista Higiene Alimentar, 15 (83), 32-42.

[3] Cardoso, M. F.; Miguel, V.; Pereira, C. A. M. (2011). Avaliação das condições higiênico-sanitárias e de boas práticas de fabricação em panificadoras. Alimentos e Nutrição Araraquara, 22 (2), 211-217.

[4] Guimarães, S. L.; Figueredo, E. L. (2010) Avaliação das condições higiênico-sanitárias de panificadoras localizadas no município de Santa Maria do Pará - PA. Rev. Bras. Tecnologia Agroindustrial, 4 (2),198-206.

[5] Oliveira, J. M.; Carvalho, M. G.; Oliveira, C. C. J. S.; Pimentel, C. L. S.; LIMA, R. F. (2016).

[6] Condições higiênico-sanitárias de unidades produtoras de refeições comerciais localizadas no entorno da Universidade Federal de Sergipe. Segurança Alimentar e Nutricional, 23(2), 897-903.

[7] Propan. (2014) Programa de Apoio a Panificação. Perfil da Panificação, 2014. Disponível em: http://www.propan.com.br/institucional.php?idcat=9> 


\section{Capítulo 20}

\section{Qualidade higiênico-sanitária na produção de refeições em hotéis segundo o porte - Gramado-RS}

\section{Patrícia Binz}

Heloísa Theodoro

\section{Juliana Rombaldi Bernardi}

Resumo: Objetivo: avaliar se há relação entre o porte dos hotéis analisados e o resultado percentual da avaliação de qualidade higiênico-sanitária de alimentos em hotéis.

Métodos: A coleta de dados foi realizada em hotéis da cidade de Gramado, no Rio Grande do Sul, por ser uma das principais destinações turísticas do estado. A pesquisa ocorreu durante os meses de agosto e setembro de 2014. Para isso, foram selecionados seis hotéis que se localizavam nesta cidade, a partir de um sorteio aleatório entre os 77 estabelecimentos descritos na listagem do município.

Resultados: No somatório do resultado dos hotéis, divididos por porte, não houve diferença significativa entre eles $(p>0,05)$. Houve diferença significativa no item responsabilidade $(p=0,05)$, e tendência na avaliação do preparo do alimento $(p=0,07)$. Os hotéis de grande porte demonstraram resultado melhor em responsabilidade, já os de médio e pequeno porte tiveram desempenho mais satisfatório no preparo do alimento.

Conclusão: Não houve relação significativa entre o porte do hotel e a implantação de boas práticas. Contudo, observou-se que outros estudos podem ser realizados acerca da preocupação quanto a influência do tamanho do estabelecimento em relação às boas práticas. Assim podem-se desenvolver ferramentas que facilitem a adesão de procedimentos para a segurança alimentar.

Palavras-chave: Controle de qualidade, boas práticas de manipulação, turismo. 


\section{INTRODUÇÃO}

A economia brasileira apresentou expansão de $24,6 \%$ entre 2003 a 2009 e o setor do turismo cresceu $32,4 \%$. No ano de 2014, o Brasil foi sede da Copa do Mundo, o que gerou grandes expectativas nesse setor. Observou-se que ocorreu um impulso ainda maior para o turismo internacional devido aos Jogos Olímpicos de 2016. Para o ano de 2022, estima-se que este setor seja responsável por 3,63 milhões de empregos. Acompanhando estes dados ocorre a necessidade de aumento das atividades de pesquisa, ensino e extensão com o objetivo de um aprofundamento da reflexão acadêmica sobre a temática do turismo.

O serviço de hotelaria, um exemplo representativo do setor terciário, acompanha este crescimento acelerado de desenvolvimento do setor de turismo. São produzidos serviços de fornecimento de hospedagem, alimentação, entretenimento, segurança e bem-estar aos hóspedes.

Nesta área, grande parte dos estabelecimentos possui oferta de alimentação, seja no café da manhã ou em outras opções de refeições durante o período de hospedagem. Este é um dos aspectos essenciais da atividade turística. Para os turistas, o sucesso de uma viagem também se refere a experiências com a alimentação, principalmente a inocuidade dos alimentos. Dessa forma, essas experiências podem ser inesquecíveis por lembrança positiva ou negativa.

Foi para orientar os clientes e proprietários sobre aspectos operacionais e físicos que surgiu a classificação oficial do Sistema Brasileiro de Classificação de Meios de Hospedagem (SBClass), a qual consiste em padrões que estes estabelecimentos devem seguir, não incluindo um cuidado quanto às Boas Práticas na Manipulação de Alimentos.

A incidência de doenças causadas por alimentos contaminados cresce a cada ano em todo mundo. Um alimento seguro é um direito de todo ser humano. A alimentação contaminada é apontada como uma das mais frequentes causas de doenças em turistas. Essas enfermidades são as intoxicações e infecções alimentares, que podem causar problemas ao consumidor e ao desenvolvimento do setor. Uma má reputação do estabelecimento pode transformar a sua imagem, influenciando na escolha dos clientes, pois estes exigem alimentos sãos e seguros.

A partir desta preocupação, para a melhoria da qualidade higiênico-sanitária de alimentos, que engloba o turismo e os serviços ofertados pela hotelaria, é que órgãos governamentais desenvolveram diversos sistemas para o controle da qualidade. Dentre estes, encontra-se a Resolução RDC n ${ }^{\circ} 216$, aprovada pela ANVISA (Agências Nacional de Vigilância Sanitária) em 15 de setembro de 2004, específica para restaurante e similares. Este regulamento tem por objetivo estabelecer procedimentos de Boas Práticas para garantir a qualidade do alimento nesses locais15. No âmbito estadual, a Secretaria de Saúde do estado do Rio Grande do Sul criou a Portaria $N^{\circ} 78 / 2009$, que aprova a Lista de Verificação em Boas Práticas para Serviços de Alimentação e Normas para Cursos de Capacitação em Boas Práticas para Serviços de Alimentação.

Assim, o objetivo deste estudo foi avaliar se há relação entre o porte dos hotéis analisados e o resultado percentual da avaliação de qualidade higiênico-sanitária de alimentos em hotéis de Gramado-RS.

\section{MÉTODOS}

Trata-se de um estudo exploratório, descritivo e quantitativo. A coleta de dados foi realizada em hotéis da cidade de Gramado, no Rio Grande do Sul, por ser uma das principais destinações turísticas do estado. A pesquisa ocorreu durante os meses de agosto e setembro de 2014.

Para a realização do trabalho, foram selecionados seis hotéis que se localizavam na cidade, a partir de um sorteio entre os 77 estabelecimentos descritos na listagem do município. 0 contato foi realizado através de email e telefone, quando não houve retorno de algum responsável pelo hotel foi entregue uma carta sobre a pesquisa diretamente no local. Os estabelecimentos foram subdivididos em três duplas. Cada dupla selecionada correspondia a um nível classificatório (porte), assim, hotéis de pequeno porte foram aqueles que continham até 50 unidades habitacionais $(\mathrm{UH})$, os de médio porte de 50 a $100 \mathrm{UH}$ e os de grande $\mathrm{F}$ acima de $100 \mathrm{UH}$.

Inicialmente, foram sorteados seis hotéis através do endereço eletrônico http//:www.sorteador.com.pr. Este foi realizado por grupos de pequeno, médio e grande porte, assim foram escolhidos dois estabelecimentos de cada grupo. Contatou-se por correio eletrônico e carta entregue diretamente no local, havendo o retorno positivo de um estabelecimento. Após foram convidados a participar mais 35 hotéis 
aleatórios através de correio eletrônico, aceitando participar mais dois hotéis. Através de ligação nos locais de escolha aleatória, solicitando a participação, três destes aceitaram. Foram aplicados os check list entre os meses de agosto e setembro de 2014.

No trabalho, foram inseridos os hotéis pertencentes à lista de estabelecimentos da prefeitura da cidade de Gramado - RS. Foram excluídos do trabalho aqueles hotéis que não apresentaram cozinha ou área de manipulação de alimentos em sua estrutura.

Na sequência, foi entregue ao responsável do hotel o termo de aplicação para análise e possível aprovação do estudo no estabelecimento. Foi utilizado o check list da Portaria da Secretaria Estadual de Saúde $n^{\circ}$ $78 / 2009$, aplicado pela pesquisadora, utilizando de observações visuais e informações fornecidas pelos responsáveis da área de alimentos e bebidas. A partir desta ferramenta de avaliação, foram analisados os 149 itens, classificados como: conforme, não conforme ou não observado. Os itens foram subdivididos em: Edificação, Instalações, Equipamentos, Móveis e Utensílios; Higienização das Instalações, Equipamentos, Móveis e Utensílios; Controle Integrado de Pragas; Abastecimento de Água; Manejo de Resíduos; Manipuladores; Matérias-Primas, Ingredientes e Embalagens; Preparação do Alimento; Armazenamento e Transporte dos Alimentos Preparados; Exposição ao Consumo do Alimento Preparado; Documentação e Registro; e Responsabilidade.

Com base nos dados obtidos, foi possível diferenciá-los quanto ao resultado, e assim serem inseridos na escala de avaliação como adequado (grupo I - mais de 70\% de conformidade dos itens observados), parcialmente adequado (grupo II - 30\% a 69,9\% de conformidade dos itens observados) e inadequado (grupo III - menos de 30\% de conformidade dos itens observados). A partir desta avaliação, com os hotéis já definidos na escala, foi estabelecida a relação entre a classificação hoteleira de porte e o resultado da avaliação de Boas Práticas. Após o término do estudo, foram entregues para cada responsável dos hotéis os resultados contendo o percentual de adequação geral e por itens avaliados. 0 preenchimento de cada formulário ocorreu em aproximadamente 180 minutos.

Os dados foram apresentados por meio de tabelas, representando o número absoluto e o resultado percentual de cada item da avaliação. Para construção dos grupos de análise de acordo com o check list foram somadas todas as respostas para cada item sendo considerado 1 (um) como conforme ou adequado e 2 (dois) como não conforme ou inadequado. Foram retirados da análise os itens que não se aplicaram aos hotéis. Após a soma, foi criado um escore a partir de tercis com base nos resultados e atribuído como adequado o tercil inferior, parcialmente adequado o tercil médio e inadequado o tercil superior que somou mais itens não conforme. Realizou-se o teste de qui-quadrado com a categorização de adequação em relação ao porte dos hotéis, considerou-se estatisticamente significativa os resultados com $\mathrm{p}$ valor $\leq$ 0,05. Os dados foram digitados no programa estatístico SPSS (Statistical Package for the Social Sciences) versão 18.0 para análises.

A partir da concordância dos responsáveis pelos estabelecimentos e assinatura no termo de aceite (Termo de Utilização dos Dados), foi aplicado o check list. No estudo foram consideradas medidas de cuidados éticos. Todos os dados foram utilizados exclusivamente para este trabalho de pesquisa e todas as informações foram mantidas em caráter sigiloso. Após o término do estudo, foram entregues para cada participante os resultados da atual pesquisa para observação dos dados.

\section{RESULTADOS}

Foram analisados para este estudo seis hotéis da cidade de Gramado - RS, sendo dois de pequeno porte, dois de médio porte e dois de grande porte. A pesquisa foi aplicada entre os meses de agosto e setembro de 2014.

A tabela 1 demonstra a análise e comparação do percentual observado no check list aplicado nos diferentes portes hoteleiros. Houve diferença significativa no item responsabilidade $(p=0,05)$, e tendência na avaliação do preparo do alimento $(\mathrm{p}=0,07)$. Os hotéis de grande porte demonstraram melhor resultado em responsabilidade, já os de médio e pequeno porte tiveram desempenho mais satisfatório no preparo do alimento. Observou-se que não houve diferença estatisticamente significativa entre os demais itens ( $p>0,05)$. Em relação à variável armazenamento e transporte de alimentos prontos, nas modalidades pequeno e médio porte de hotéis, não se aplicaram estes critérios, pois não desempenham estas atividades e apenas um hotel de grande porte estava adequado e o outro também não desenvolvia esta atividade. Quanto à variável abastecimento de água, todos os hotéis se enquadraram como adequados. 
Na tabela 2, há descrição do somatório do resultado dos hotéis, divididos por porte. Não havendo diferença significativa entre eles $(p>0,05)$.

\section{DISCUSSÃo}

Para este estudo, foi utilizado o check list da portaria estadual nำ78/2009, que serve de base para posterior diagnóstico dos pontos negativos e positivos da unidade, havendo assim maior facilidade para entendimento e observação da situação higiênico-sanitária do local20. Foram identificadas não conformidades em todas as análises, o que reforça a necessidade de atenção para a qualidade alimentar. Existem poucas pesquisas que observam as Boas Práticas (BP) de alimentos, principalmente em hotéis, mas sabe-se que são fundamentais para a redução de perigos alimentares em turistas. A presente pesquisa destaca-se como inovadora, pois não foram encontrados estudos, ao que se sabe, que estabeleçam uma relação entre o porte hoteleiro e o resultado de análise de Boas Práticas.

Em um estudo de Ebone et al, que analisaram unidades produtoras de refeições comerciais, não houve relação significativa entre o porte das empresas e o uso de sistemas de qualidade. Assim como o atual estudo que não demonstrou diferença no resultado geral. Neste estudo, observou-se diferença significativa entre os portes hoteleiros no item responsabilidade, não havendo interferência sobre os outros itens. Já no estudo de Souza et al7 que analisaram três tipos de estabelecimentos, entre estes os hotéis, observou-se que possuir um responsável pelo estabelecimento, sendo ele nutricionista ou gerente de alimentos e bebidas, pode interferir positivamente no cumprimento geral das normas de Boas Práticas.

Sobre os itens de edificação observou-se melhor resultado nos hotéis de médio e grande porte, mas não havendo diferença significativa entre estes. A sua maioria se encontra em parcialmente adequado, o que pode demonstrar um melhor planejamento do local de manipulação, possivelmente por contar com um profissional habilitado.

0 resultado entre os hotéis no item higienização foi bem aproximado, sendo que a metade deles se encontrava em classificação adequado. Souza et al7 verificaram um percentual de $93 \%$ de adequação. Os hotéis tiveram um resultado melhor quando comparados à unidade de alimentação e nutrição (UAN) e restaurantes comerciais 20 .

O preparo de alimentos, que houve tendência a não semelhança entre os analisados, teve melhor resultado nos hotéis de pequeno porte. 0 que pode demonstrar maior controle e cuidado devido à sua demanda ser reduzida. Mesmo assim, não há monitoramento de um profissional habilitado. Este fato pode ser crucial para a prevenção da maioria das doenças transmitidas por alimentos.

No estudo de Akutsu et al20 os hotéis se destacaram em edificação, manipulação e fluxo de produção. Diferente da atual análise, que demonstrou melhor resultado no abastecimento de água nos seis hotéis analisados. Corroborando com os dados, o hotel analisado por Souza et al7, teve $100 \%$ de adequação neste item assim como na avaliação de uma UAN analisada por Mariano \& Moura.

Ebone et al21 pesquisaram os principais motivos para a não implementação de Boas Práticas nas empresas. Entre eles foram apontados o fato do controle ser realizado pelo próprio gerente ou funcionário do local, pelo orçamento ou por ser considerada pequena. 0 comprometimento da administração com a segurança alimentar parece ter o efeito mais positivo em relação aos cuidados de segurança alimentar. Além disso, é necessário que o governo incentive os estabelecimentos à segurança alimentar, realizando as devidas inspeções.

No item manipulação, em um estudo de Genta et al observou-se de 12,5\% a 56,3\% de não conformidades na aplicação de um check list em seis restaurantes. Comparado com UANs e restaurantes comerciais, os hotéis tiveram os melhores resultados20. Neste aspecto, Soares et al identificaram que a contaminação por meio da manipulação de alimentos foi menor, após treinamento, em estabelecimentos maiores. No presente estudo, não houve diferença em manipulação entre os portes, mas é imprescindível para a segurança alimentar que haja capacitação de manipuladores e assim mudanças de comportamento nos estabelecimentos22. Os resultados obtidos em uma UAN hoteleira, na cidade de São Paulo (SP) evidenciaram boas condições higiênico-sanitárias, porém, concluiu-se ser necessário corrigir as falhas existentes, como higiene dos manipuladores, realização de controles e registros periódicos.

Pode-se considerar que alguns itens do estudo ainda apresentam um resultado sugestivo da situação de BP nos hotéis, apesar da não significância estatística, pois quanto maior o porte do hotel há mais preocupação com a responsabilidade e os documentos que envolvem os processos de boas práticas. Já os menores apresentam um melhor processo no preparo de alimentos. 0 que sugere que os menores devem 
dar mais atenção aos aspectos formais e os maiores com os cuidados na manipulação e conservação dos alimentos durante o seu preparo.

Era esperado um resultado significativo em boas práticas entre os portes, devido à diferença estrutural, de procedimentos e número de funcionários entre os tamanhos dos hotéis comumente encontrados. Entretanto, isso não foi observado, pois não houve diferença entre as BP em geral entre os portes dos hotéis na cidade em estudo, podendo demonstrar que há homogeneidade entre estes estabelecimentos.

Nota-se como limitação da pesquisa o número reduzido de amostra, devido à dificuldade de aceitação por parte dos estabelecimentos em participar do estudo, além de os hotéis analisados estarem em uma cidade turística do estado. Diante do exposto, espera-se ampliar as discussões acerca da segurança alimentar no turismo e sua relação com as dificuldades de implantação de BP.

\section{CONCLUSÃO}

0 atual estudo pretendeu demonstrar que pode haver maiores dificuldades na implantação de boas práticas dependendo do porte de um hotel, mas que isso não foi observado nesta pesquisa, podendo-se sugerir que o resultado de BP não tem relação com o porte do estabelecimento. A maneira ideal de prevenir os perigos alimentares é através das BP. Para isso acontecer, deve-se ter um envolvimento e preocupação da alta gestão do estabelecimento.

Embora este estudo não tenha demonstrado diferença significativa entre o resultado geral de BP, pode-se observar que um item específico pode influenciar toda a cadeia de condições higiênico-sanitárias do estabelecimento. Reforçando assim a necessidade de um profissional habilitado para assegurar a qualidade alimentar.

O turista depende do desempenho da Vigilância Sanitária local e dos procedimentos do hotel para assegurar a qualidade dos alimentos que são oferecidos no serviço. Pela falta de informação existente, muitos turistas tendem a confiar sua escolha em hotéis de médio e grande porte, por serem mais conhecidos popularmente e passarem a impressão de possuir procedimentos bem estabelecidos. Diferente dos hotéis de pequeno porte, que embora pareçam mais flexíveis, são menos conhecidos e a maior parte dos procedimentos são realizados de forma informal. Por isso, deve haver mais pesquisas e incentivos nesta área.

Nota-se uma necessidade de maior controle de BP nos estabelecimentos que produzem e manipulam alimentos nesta cidade. Estes requisitos, além de oferecerem segurança para o cliente, são importantes para o próprio desenvolvimento do hotel, pois é imprescindível para o mercado do turismo e da alimentação, independentemente do porte do hotel, que se crie um diferencial competitivo através da qualidade dos alimentos.

Na efetivação desta pesquisa observou-se que outros estudos podem ser realizados acerca da preocupação quanto a influência do tamanho do estabelecimento em relação as BP. Pois assim podem-se desenvolver ferramentas que facilitem a adesão de procedimentos para a segurança alimentar, além de influenciar o desenvolvimento de um sistema de controle mais rigoroso por parte dos órgãos fiscalizadores.

\section{AGRADECIMENTOS}

Os autores agradecem a gestão e os manipuladores dos hotéis avaliados por viabilizarem a realização desta pesquisa.

\section{COLABORADORES}

P. BINZ participou da concepção, desenho do estudo, coleta, pesquisa bibliográfica, interpretação dos dados e redação do artigo. J. R. BERNARDI colaborou com a concepção e desenho do estudo, redação e revisão crítica do artigo. H. THEODORO colaborou com a concepção e desenho do estudo, análise estatística dos dados e revisão crítica do artigo. 


\section{REFERÊNCIAS}

[1] Brasil. Plano Nacional de Turismo 2013-2016. Brasília: Ministério do Turismo; 2013 [acesso 2019, julh 08]. Disponível em: < http://www.turismo.gov.br/images/pdf/plano_nacional_2013.pdf>.

[2] FIFA World Cup [Internet]. Os números da Copa do Mundo da Fifa. 2014 [acesso 2019, julh 08]. Disponível em:

<http://resources.fifa.com/mm/document/tournament/competition/02/44/29/89/fifaworldcupinnumbers_120714 _v7_por_portuguese.pdf>.

[3] Cunha DT, Oliveira ABA, Sacol ALF, Tondo EC, Junior EAS, Ginani VC, et al. Food safety of food services within the destinations of the 2014 FIFA World Cup in Brazil: Development and reliability assessment of the official evaluation instrument. Food Research International. 2014; 57: 95-103.

[4] Proni MW. Observações sobre os impactos econômicos esperados dos jogos olímpicos 2016. Motrivivência. 2009; 32: 49-70.

[5] Branco GM, Ribeiro JLD, Tinoco MAC. Determinantes da satisfação e atributos da qualidade em serviços de hotelaria. Produção. 2010; 20 (4): 576-588.

[6] Pereira FF, Coutinho HRM. Hotelaria: da era antiga aos dias atuais. Rev. Aboré. 2007; 3.

[7] Souza CH, Sathler J, Jorge MN, Horst RFML. Avaliação das condições higiênico sanitárias em uma unidade de alimentação e nutrição hoteleira, na cidade de Timóteo - MG. Rev. Dig. de Nut. 2009; 3 (4): 312-329.

[8] Brasil. Ministério do Turismo. Portaria no 100 de 16 de junho de 2011. Institui o Sistema Brasileiro de Classificação de Meios de Hospedagem (SBClass), estabelece os critérios de classificação destes, cria o Conselho Técnico Nacional de Classificação de Meios de Hospedagem (CTClass) e dá outras providências. Brasília: MTUR; 2011.

[9] Menezes PDL, Silva JC. Análise do sistema oficial de classificação dos meios de hospedagem do Brasil. Rev Iberoamericana de Turismo. 2013; 3(1): 57-70.

[10] Pinheiro MB, Wada TC, Pereira CAM. Análise microbiológica de tábuas de manipulação de alimentos de uma instituição de ensino superior em São Carlos, SP. Rev Simbio-Logias. 2010; 5(3): 115-124.

[11] Fletcher SM, Maharaj SR, James K. Description of the food safety system in hotels and how it compares with HACCP standards. Journal of Travel Medicine. 2009; 16(1): 35-41.

[12] Brasil. Ministério do Turismo [Intermet]. Estudos da Competitividade do Turismo Brasileiro: Serviços de

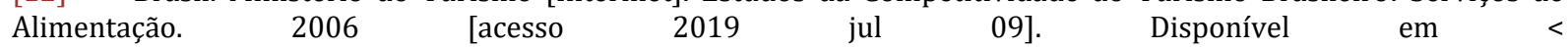
http://www.turismo.gov.br/export/sites/default/turismo/o_ministerio/publicacoes/downloads_publicacoes_servico s_de_alimentacao>.

[13] Jomori MM, Proença RPC, Calvo MCM. Determinantes de escolha alimentar. Rev Nut. 2008; 21(1): 63-73.

[14] Sousa CP. Segurança alimentar e doenças veiculadas por alimentos: utilização do grupo coliforme como um dos indicadores de qualidade de alimentos. Rev APS. 2006; 9(1): 83-88.

[15] Brasil. Ministério da Saúde. Agência Nacional de Vigilância Sanitária. Resolução RDC no 216, de 15 de setembro de 2004. Dispõe sobre regulamento técnico de Boas Práticas para serviços de alimentação: MS; 2004.

[16] Rio Grande do Sul. Secretaria da Saúde. Portaria no 78 de 30 de janeiro de 2009. Aprova lista de verificação em Boas Práticas para serviços de alimentação. Porto Alegre: SES; 2009.

[17] Curtis LF, Hoffmann VE. Características determinantes de redes: um estudo nos relacionamentos do setor hoteleiro das destinações turísticas de Gramado e Canela (RS). Rev Neg. 2009; 14(1): 48-62.

[18] Brasil. Ministério do Turismo [Internet]. Cartilha de orientação básica: hotel. 2010. [acesso 2019 jul 09]. Disponível em: http://www.turismo.gov.br/export/sites/default/turismo/o_ministerio/publicacoes/downloads_publicacoes>.

[19] Brasil. Ministério do Turismo [Internet]. Cartilha de orientação básica: Sistema brasileiro de classificação de meios de hospedagem. 2010. [acesso 2019 jul 09]. Disponível em: < http://www.turismo.gov.br/export/sites/default/turismo/o_ministerio/publicacoes/downloads_publicacoes>.

[20] Akutsu RC, Botelho RA, Camargo EB, Sávio KEO, Araújo WC. Adequação das boas práticas de fabricação em serviços de alimentação. Rev Nut. 2005; 18(3): 419-427.

[21] Ebone MV, Cavalli SB, Lopes SJ. Segurança e qualidade higiênico-sanitária em unidades produtoras de refeições comerciais. Rev Nut. 2011; 24(5): 725-734.

[22] Gomes NAAA, Campos MRH, Monego ET. Aspectos higiênico-sanitários no processo produtivo dos alimentos em escolas públicas do Estado de Goiás, Brasil. Rev Nut. 2012; 25(4): 473-485.

[23] Mariano CG, Moura PN. Avaliação das boas práticas de fabricação em unidade produtora de refeições (UPR) auto-gestão do interior do estado de São Paulo. Rev Salus. 2008; 2(2): 73-81. 
[24] Wu SL. Factors influencing the implementation of food safety control systems in Taiwanese international tourist hotels. Food Control. 2012; Food Control. 28 (2): 265-272.

[25] Genta TMS, Mauricio AA, Matioli G. Avaliação de boas práticas através de check- list aplicado em restaurantes self-service da região central de Maringá, estado do Paraná. Rev Acta Sci. 2005; 27(2): 151-156.

[26] Soares K, Garcia-Diez J, Esteves A, Oliveira I, Saraiva C. Evaluation of food safety training on hygienic conditions in food establishments. Food Control. 2013; 24 (2): 613-618.

[27] Lopes JE, de Souza M. Avaliação das Condições Higienicossanitárias em uma Unidade de Alimentação e Nutrição Hoteleira. Higiene Alimentar. 2016; 30 (256/257): 50-54. 


\section{ANEXO}

TABELA 1. Análise dos hotéis por porte e itens do check list. Gramado- RS, 2014.

\begin{tabular}{|c|c|c|c|c|c|}
\hline \multirow{3}{*}{ Grupo } & \multirow{3}{*}{ Resultado Check List } & \multicolumn{3}{|c|}{ Porte do Hotel } & \multirow{3}{*}{ Valor $\mathrm{p}$} \\
\hline & & Pequeno & Médio & Grande & \\
\hline & & $n(\%)$ & $\mathrm{n}(\%)$ & $\mathrm{n}(\%)$ & \\
\hline \multirow{3}{*}{ Edificação } & Adequado & 0 & 0 & $1(50)$ & \multirow{3}{*}{0,11} \\
\hline & Parcialmente Adequado & $1(50)$ & $2(100)$ & $1(50)$ & \\
\hline & Inadequado & $1(50)$ & 0 & 0 & \\
\hline \multirow{3}{*}{ Higienização } & Adequado & $1(50)$ & $1(50)$ & $1(50)$ & \multirow{3}{*}{0,56} \\
\hline & Parcialmente Adequado & $1(50)$ & 0 & $1(50)$ & \\
\hline & Inadequado & 0 & $1(50)$ & 0 & \\
\hline \multirow{3}{*}{ Controle Integrado de Pragas } & Adequado & $1(50)$ & $1(50)$ & $2(100)$ & \multirow{3}{*}{0,23} \\
\hline & Parcialmente Adequado & 0 & $1(50)$ & 0 & \\
\hline & Inadequado & $1(50)$ & 0 & 0 & \\
\hline \multirow{3}{*}{ Manejo de Resíduos } & Adequado & $1(50)$ & $1(50)$ & $2(100)$ & \multirow{3}{*}{0,23} \\
\hline & Parcialmente Adequado & 0 & $1(50)$ & 0 & \\
\hline & Inadequado & $1(50)$ & 0 & 0 & \\
\hline \multirow{3}{*}{ Manipuladores } & Adequado & 0 & 0 & $1(50)$ & \multirow{3}{*}{0,51} \\
\hline & Parcialmente Adequado & $1(50)$ & $2(100)$ & 0 & \\
\hline & Inadequado & $1(50)$ & 0 & $1(50)$ & \\
\hline \multirow{3}{*}{ Matéria-Prima } & Adequado & $2(100)$ & $1(50)$ & $1(50)$ & \multirow{3}{*}{0,23} \\
\hline & Parcialmente Adequado & 0 & $1(50)$ & 0 & \\
\hline & Inadequado & 0 & 0 & $1(50)$ & \\
\hline \multirow{3}{*}{ Preparo do Alimento } & Adequado & $2(100)$ & $2(100)$ & 0 & \multirow{3}{*}{0,07} \\
\hline & Parcialmente Adequado & 0 & 0 & $1(50)$ & \\
\hline & Inadequado & 0 & 0 & $1(50)$ & \\
\hline \multirow{3}{*}{ Exposição do Alimento } & Adequado & $1(50)$ & $2(100)$ & $1(50)$ & \multirow{3}{*}{0,47} \\
\hline & Parcialmente Adequado & 0 & 0 & 0 & \\
\hline & Inadequado & $1(50)$ & 0 & $1(50)$ & \\
\hline \multirow{3}{*}{ Documentação } & Adequado & 0 & $1(50)$ & $1(50)$ & \multirow{3}{*}{0,09} \\
\hline & Parcialmente Adequado & 0 & $1(50)$ & $1(50)$ & \\
\hline & Inadequado & $2(100)$ & 0 & 0 & \\
\hline \multirow{3}{*}{ Responsabilidade } & Adequado & 0 & 0 & $2(100)$ & \multirow{3}{*}{0,05} \\
\hline & Parcialmente Adequado & $2(100)$ & $2(100)$ & 0 & \\
\hline & Inadequado & 0 & 0 & 0 & \\
\hline
\end{tabular}

TABELA 2. Análise dos hotéis por porte. Gramado - RS, 2014.

\begin{tabular}{|c|c|c|c|c|c|}
\hline Grupo & Resultado Check List & $\begin{array}{c}\text { Pequeno } \\
N(\%)\end{array}$ & $\begin{array}{l}\text { Médio } \\
\text { N(\%) }\end{array}$ & $\begin{array}{l}\text { Grande } \\
\mathrm{N}(\%)\end{array}$ & Valor $\mathrm{p}$ \\
\hline \multirow{3}{*}{ Soma dos grupos } & Adequado & 0 & 0 & $1(50)$ & \\
\hline & Parcialmente Adequado & $1(50)$ & $2(100)$ & 0 & 0,51 \\
\hline & Inadequado & $1(50)$ & 0 & $1(50)$ & \\
\hline
\end{tabular}




\section{Capítulo 21}

Resíduos de agrotóxicos em mel produzido nas casas de mel da região das Missões- $R S$

\section{Fernanda Leal Leães}

Karla Joseane Perez

Thais de Oliveira Lopes

Resumo: Este estudo analisou amostras de mel produzidas em casas de mel na região das Missões - RS, para determinar se o produto estava contaminado com resíduos de agrotóxicos que são amplamente utilizados pela agricultura local. Um questionário foi aplicado para obter informações dos apicultores sobre a situação atual da apicultura nesta região. A análise para a detecção de resíduos de agrotóxicos foi realizada pelo método de QuEChERS modificado e análise por cromatografia líquida com detecção por espectrometria de massas. A região é composta de pequenos e médios apicultores e muitos deles também são agricultores. Houve diminuição na produção, morte e desorientação de enxames de abelhas nos últimos anos, sendo que os apicultores associam estes fatores principalmente ao uso de agrotóxicos nas lavouras. Porém, não há resíduos de agrotóxicos nas amostras, provando que o mel que está sendo produzido e comercializado na região é seguro para os consumidores.

Palavras chave: Apicultura, monoculturas, resíduos de agrotóxicos 


\section{INTRODUÇÃO}

A apicultura adequa-se a diversos sistemas de produção integrada, interferindo pouco na ocupação de área das outras atividades (Gois et al., 2013). Ela é realizada em sua grande maioria por agricultores que possuem a criação de abelhas como uma atividade complementar de renda em suas propriedades, tornando-a pulverizada, pouco especializada e de baixa intensidade tecnológica (Coronel et al., 2011).

Como retêm produtos químicos e outros poluentes do ambiente tanto externo como interno para suas colmeias, as abelhas são consideradas indicadores biológicos (Wu et al., 2011). Durante o forrageamento, que abrange um raio de $9 \mathrm{~km}$ em torno da colmeia, uma grande variabilidade de fatores não podem ser controlados. Dentre eles os fatores de stress, a estrutura do solo, o clima e a combinação de plantas atraentes para as abelhas (Van der Sluijs et al., 2013).

O uso de pesticidas tem levado a grandes lucros econômicos na agricultura (Li et al., 2013) e tornou-se indispensável para a promoção do atual modelo da agricultura brasileira. Porém, após a aplicação desses produtos químicos eles podem se dispersar das mais variadas formas. Assim, estes compostos entram em contato com a água e o solo por meio da lixiviação e pelo escoamento da água, podem ser transferidos para a atmosfera através da volatilização, da ressuspensão de partículas e principalmente pela dispersão no momento da aplicação aérea (Kurz et al., 2013).

Portanto, é necessário que os apicultores considerem esses fatos que podem caracterizar uma fonte secundária de contaminação, de forma acidental (Gois et al., 2013), também conhecida como contaminação por deriva (Pettis et al., 2013). É possível que as abelhas fiquem expostas aos agrotóxicos enquanto recolhem o néctar, mesmo que não estejam fazendo a coleta em locais onde estão sendo feitas as aplicações desses agroquímicos (Pettis et al., 2013).

Os consumidores vêm buscando, cada vez mais, qualidade e segurança dos alimentos que consomem e, dessa forma, informações e estudos sobre resíduos de agrotóxicos têm-se tornado uma prática habitual (Furlani et al., 2011). Sendo assim, o objetivo desse estudo é analisar amostras de mel das Casas do Mel da Região das Missões - RS a fim de determinar se há uma contaminação desse produto por resíduos de agrotóxicos usados nas lavouras. Aliado a isso também busca-se fazer uma investigação junto aos apicultores sobre o atual cenário da apicultura nessa região.

\section{MATERIAIS E MÉTODOS}

Foram coletadas 20 amostras de mel da Região das Missões, Rio Grande do Sul, Brasil. As amostras foram concedidas por apicultores dos municípios de Bossoroca, Caibaté, São Luiz Gonzaga e São Miguel das Missões, organizados em associações de apicultores e que utilizam das instalações higiênico-sanitárias das Casas do Mel, atendendo aos requisitos de higiene e qualidade. A coleta concentrou-se nesses municípios pois dentro dessa região são os que ainda apresentam maior expressividade na produção de mel e na organização em forma de associações.

0 período da coleta foi nos meses de fevereiro e março de 2016, sendo essa época escolhida para coincidir com o plantio da soja e os posteriores tratamentos com fungicidas, inseticidas, agrotóxicos no geral, que são necessários para a garantia de boa safra desse grão na região. Foram coletadas então, amostras de 5 produtores de cada um dos 4 municípios onde foi realizada a pesquisa, totalizando as 20 amostras.

Durante o período de amostragem foi aplicado um questionário com os apicultores, previamente aprovado pelo Comitê de Ética da Escola de Saúde Pública do Rio Grande do Sul, sob parecer $n^{\circ}$ 1.504.021. Esse questionário conta com questões simples, de fácil entendimento acerca da produção dos apiários, forma de obtenção de renda dos apicultores, comercialização do mel, desempenho e rendimento da produção de mel, ocorrência de desorientação e morte de enxames e possível contaminação do mel por resíduos de agrotóxicos.

Após a coleta das amostras, as mesmas foram encaminhadas para o Laboratório de Análises de Resíduos de Pesticidas (LARP) da Universidade Federal de Santa Maria (UFSM), no município de Santa Maria, Rio Grande do Sul. A determinação dos resíduos de agrotóxicos foi realizada pelo método de QuEChERS modificado e análise por cromatografia liquida com detecção por espectrometria de massas (HPLCMS/MS) proposto por Orso et al., 2011. Trata-se de um método multirresíduo, que foi modificado através da realização de uma etapa final de clean-up. Apesar dos altos níveis de açúcar e outras interferências no mel, o método proporciona uma limpeza adequada e por sua simplicidade pode ser utilizado para análises de rotina (Orso et al., 2014). 


\section{RESULTADOS E DISCUSSÃO}

De acordo com as informações prestadas pelos apicultores através dos formulários para coleta das amostras, o mel produzido por eles tem origem multifloral, é obtido através de processo de centrifugação, com apresentação líquida, com cores desde um amarelo claro a uma cor mais âmbar. Também afirmaram não utilizar nenhum tratamento químico nas colmeias, como acaricidas ou antibióticos.

Como culturas ao entorno dos apiários, foram citadas soja, milho, trigo, alfafa e pastagens não especificadas, com distâncias variando desde muito próximas (20 metros) até mais distantes (4 Km), mas situando-se em média de 100 a 500 metros. Observamos através das respostas ao questionário entregue posteriormente a coleta das amostras que os apicultores da região das Missões, que utilizam as Casas do Mel, se classificam como pequenos e médios apicultores, sendo que $40 \%$ dos entrevistados produzem anualmente em seus apiários de 500 a $1000 \mathrm{Kg}, 33 \%$ de 100 a $500 \mathrm{Kg}$ e 27\% de 1000 a $5000 \mathrm{Kg}$ (Figura 01).

Figura 01 - Resultados do questionário feito aos apicultores que utilizam as Casas do Mel da Região das Missões-RS após a coleta das amostras.

\begin{tabular}{|c|c|c|c|c|}
\hline Questões & \multicolumn{4}{|c|}{ Respostas } \\
\hline $\begin{array}{l}\text { 1-Qual a produção } \\
\text { média anual do } \\
\text { apiário? }\end{array}$ & $\begin{array}{c}\text { De } 100 \mathrm{a} \\
500 \mathrm{Kg} \\
33 \%\end{array}$ & $\begin{array}{c}\text { De } 500 \text { a } \\
1000 \mathrm{Kg} \\
40 \%\end{array}$ & $\begin{array}{c}\text { De } 1000 \mathrm{a} \\
5000 \mathrm{Kg} \\
27 \%\end{array}$ & $\begin{array}{l}\text { Mais que } \\
5000 \mathrm{Kg} \\
\text { Nenhum }\end{array}$ \\
\hline $\begin{array}{l}\text { 2- A apicultura é a } \\
\text { sua principal forma } \\
\text { de obtenção de } \\
\text { renda? }\end{array}$ & \multicolumn{2}{|c|}{$\begin{array}{l}\text { Sim } \\
7 \%\end{array}$} & \multicolumn{2}{|c|}{$\begin{array}{l}\text { Não } \\
93 \%\end{array}$} \\
\hline $\begin{array}{l}\text { *3- Quais outras } \\
\text { atividades exercidas } \\
\text { que geram renda? }\end{array}$ & $\begin{array}{c}\text { Pecuária } \\
\text { leiteira } \\
13 \%\end{array}$ & $\begin{array}{c}\text { Pecuária de } \\
\text { corte } \\
67 \%\end{array}$ & $\begin{array}{c}\text { Agricultura } \\
53 \%\end{array}$ & $\begin{array}{l}\text { Outras } \\
47 \%\end{array}$ \\
\hline $\begin{array}{l}\text { 4- Aonde o mel é } \\
\text { comercializado? }\end{array}$ & $\begin{array}{c}\text { Feiras de } \\
\text { produtores } \\
40 \%\end{array}$ & $\begin{array}{c}\text { Direto ao } \\
\text { consumidor } \\
33 \%\end{array}$ & $\begin{array}{c}\text { Mercados } \\
7 \%\end{array}$ & $\begin{array}{c}\text { A granel } \\
\text { (Associação) } \\
60 \%\end{array}$ \\
\hline $\begin{array}{l}\text { 5- Você tem } \\
\text { observado queda na } \\
\text { produção nos últimos } \\
\text { anos? }\end{array}$ & \multicolumn{2}{|c|}{$\begin{array}{l}\operatorname{Sim} \\
93 \%\end{array}$} & \multicolumn{2}{|c|}{$\begin{array}{l}\text { Não } \\
7 \%\end{array}$} \\
\hline $\begin{array}{l}\text { *6-O que pode estar } \\
\text { afetando no } \\
\text { rendimento } \\
\text { apiário? }\end{array}$ & $\begin{array}{c}\text { Agrotóxicos } \\
\text { ao entorno } \\
87 \%\end{array}$ & $\begin{array}{c}\text { Excesso de } \\
\text { Chuvas } \\
73 \%\end{array}$ & $\begin{array}{l}\text { Ventos } \\
\text { Fortes } \\
13 \%\end{array}$ & $\begin{array}{c}\text { Doença na } \\
\text { colmeia } \\
20 \%\end{array}$ \\
\hline $\begin{array}{l}\text { 7-Tem percebido } \\
\text { desorientação e } \\
\text { morte das abelhas? }\end{array}$ & \multicolumn{2}{|c|}{$\begin{array}{l}\text { Sim } \\
93 \%\end{array}$} & \multicolumn{2}{|c|}{$\begin{array}{l}\text { Não } \\
7 \%\end{array}$} \\
\hline $\begin{array}{lrr}8 \text {-Esses fatos } & \text { tem } \\
\text { relação com } & \text { os } \\
\text { agrotóxicos } & \\
\text { utilizados } & \text { nas } \\
\text { lavouras? } & \\
\end{array}$ & $\begin{array}{l}\operatorname{Sim} \\
67 \%\end{array}$ & \multicolumn{2}{|c|}{$\begin{array}{l}\text { Não } \\
13 \%\end{array}$} & $\begin{array}{l}\text { Não sei } \\
20 \%\end{array}$ \\
\hline $\begin{array}{lr}\text { 9- O mel produzido } \\
\text { na região pode estar } \\
\text { contaminado com } \\
\text { resíduos } & \text { de } \\
\text { agrotóxicos? } & \end{array}$ & $\begin{array}{l}\operatorname{Sim} \\
27 \%\end{array}$ & \multicolumn{2}{|c|}{$\begin{array}{l}\text { Não } \\
7 \%\end{array}$} & $\begin{array}{l}\text { Não sei } \\
66 \%\end{array}$ \\
\hline
\end{tabular}

De modo geral, a apicultura no Brasil é desenvolvida por médios e pequenos proprietários rurais, por meio de unidades familiares, que em sua maioria trabalha com a apicultura fixa, onde as colmeias permanecem na mesma área ao longo do ano (Da Silva, 2010). Nenhum dos colaboradores produz mais que $5000 \mathrm{Kg}$. Apenas um dos entrevistados afirmou ser a apicultura a sua principal forma de obtenção de renda, todos os outros possuem outras fontes de renda pois poucos conseguem sobreviver somente com a renda do mel, devido a fatores como baixa produtividade, irregularidade nas floradas, das instabilidades climáticas (seca e frio) e da falta de planejamento (Da Silva, 2010).

A apicultura é considerada hoje uma das grandes opções para a agricultura familiar por proporcionar o aumento de renda, através da oportunidade de aproveitamento da potencialidade natural de meio ambiente e de sua capacidade produtiva (De Queiroga et al., 2015). Esperava-se que a agricultura fosse a 
atividade mais exercida em consórcio com a apicultura mas os resultados mostram que a pecuária de corte é a atividade mais exercida concomitantemente com a apicultura. Em seguida encontra-se a agricultura com $53 \%$ o que embora não seja o maior valor não deixa de ser um número expressivo. A pecuária leiteira também tem participação na renda dos entrevistados. Além dessas atividades os apicultores podiam marcar a opção outras pois poderia não se encaixar nas atividades sugeridas ou ainda ter outra atividade além. Dentro dos $47 \%$ que marcaram a opção outras, um deles diz ser comerciante e outro é piscicultor, os demais não especificaram as outras atividades.

Quando questionados sobre como é feita a comercialização do seu produto (mel), a maioria respondeu que realiza a venda a granel para a associação de apicultores da qual fazem parte. Também participam das feiras de produtores de seus municípios e praticam a venda de forma direta ao consumidor. Um dos entrevistados realiza a venda também para mercados.

Um dos grandes desafios da apicultura brasileira é aumentar o consumo interno de mel, pois muitos brasileiros ainda veem o mel como medicamento, consumindo-o apenas em caso de doença (Da Silva, 2010). O consumo de mel no Brasil está estimado em aproximadamente 200g/pessoa/ano, o que é considerado muito baixo se comparado a alguns países da Europa, como a Alemanha e Suíça, onde se calcula um consumo de $2.400 \mathrm{~g} / \mathrm{pessoa} /$ ano (De Queiroga et al., 2015). Mas na região em estudo, aquelas pessoas que ainda tem o hábito de consumir mel e buscam sempre por esse produto, tem percebido uma queda na produção de mel nos últimos anos e tem relatado dificuldades para achar mel para venda aqui na região.

Essa queda foi confirmada pelos apicultores através do questionário, onde a maioria afirma ter tido queda no rendimento dos seus apiários. Essa queda em $87 \% \%$ das vezes foi relacionada ao uso de agrotóxicos nas culturas ao entorno. Isso mostra que os apicultores precisam considerar não só uso de agrotóxicos nos campos em que eles estão colocando suas abelhas, mas também programas de pulverização próximos a esses campos, que podem contribuir para a contaminação por deriva (Pettis et al., 2013).

Em estudo feito por Da Silva (2010), os apicultores acusam os agricultores de serem responsáveis pelo uso de pesticidas ao redor de seus apiários, porém a agricultura é uma das outras fontes de rendas desses próprios produtores de mel. Assim, é evidente que a prática da apicultura necessita de acompanhamento de técnicos especializados para ajudar nesse processo de conscientização dos produtores sobre como uma atividade interfere na outra e quais procedimentos adotar para solucionar os problemas que surgem desse consórcio de atividades.

Outros fatores associados foram o excesso de chuvas e ventos fortes, que tratam de fatores de ordem climática ao qual a apicultura está exposta, não sendo possível ao homem evitar seus prejuízos, diferentemente do uso de agrotóxicos. Doenças nas colmeias foram associadas em $20 \%$ das vezes como possíveis causas de queda na produção mas os apicultores não fazem uso de nenhuma medicação nas colmeias. Outros motivos citados também foram o abandono dos apiários, falta de cuidado e ausência de mata nativa. Sabe-se que se não houver um acompanhamento adequado das colmeias, poderão ocorrer perdas através de inimigos naturais, falta de alimento e água, morte da rainha, entre outros fatores e por isso visitas periódicas aos apiários são extremamente importantes para a garantia da qualidade do produto final (Simionatto et al., 2012).

Em relação a percepção de desorientação e/ou morte dos enxames em suas propriedades ou em propriedades vizinhas os apicultores afirmaram ter notado esse desequilíbrio, com exceção de um apicultor que não notou nenhum tipo de desorientação ou mortes de enxames de abelhas. Quando indagados se esses fatores podem estar relacionados ao uso de agrotóxicos na agricultura, a maioria deles (67\%) acreditam que há essa relação, $20 \%$ não souberam opinar e $13 \%$ acreditam que não há relação entre desorientação e morte de enxames devido ao uso de agrotóxicos na agricultura.

Quando há a aplicação de agrotóxicos, eles podem se dispersar das mais variadas formas no ambiente, entrando em contato com a água e o solo por meio da lixiviação e pelo escoamento da água, assim como podem ser transferidos para a atmosfera através da volatilização, da ressuspensão de partículas e principalmente pela dispersão no momento da aplicação aérea (Kurz et al., 249 2013). Com isso as espécies próximas ao local de aplicação agrotóxicos e as que visitam o local podem ser contaminadas, como é o caso das abelhas, caracterizando uma fonte secundária de contaminação, de forma acidental 252 (Gois et al., 2013).

São necessários mais estudos sobre a morte e desorientação de enxames de abelhas no Brasil, pois o uso de agrotóxicos na agricultura tem sido apontado como o maior causador nas perdas de enxames, queda de produção e inviabilidade da continuação da apicultura. 
Na pesquisa de resíduos de agrotóxicos no mel, utilizando as amostras cedidas pelos apicultores que responderam ao questionário, foram determinados 79 tipos de agrotóxicos simultaneamente de forma rápida e efetiva.

Não foram detectados nenhum dos 79 analitos nas amostras utilizadas nesse estudo. Isso significa dizer que se há algum resíduo, este está abaixo dos limites de detecção acima expostos. Em estudo semelhante Orso e colaboradores (2014), também não detectaram resíduos de agrotóxicos na maioria das amostras de mel. Porém algumas amostras estavam contaminadas e os autores associaram essa contaminação ao ambiente onde as abelhas ficaram expostas a esses contaminantes. Com isso é possível afirmar que o mel que está sendo produzido e beneficiado nas casas do mel da Região das Missões é seguro para o consumidor.

Com os resultados obtidos nesse estudo pela análise de resíduos de agrotóxicos nas amostras de mel, pode-se esclarecer a última questão do questionário realizado pelos apicultores colaboradores da pesquisa. Em maioria, eles não souberam opinar se o mel poderia estar contaminado com resíduos de agrotóxicos. Considerando que o mercado consumidor, cada vez mais preocupado com a alimentação, busca então adquirir um produto livre de contaminação, sem resíduos de agrotóxicos (Gois et al., 2013), a confirmação através do resultado desse estudo de que o mel, produzido e comercializado na região das Missões, extraído nas casas de mel e comercializados com o selo do Serviço de Inspeção Municipal está livre dessas contaminações o que o torna apto para atender a demanda do mercado. Essa garantia pode agregar ainda mais valor ao mel e assim estimular ainda mais a continuação e manutenção da prática da apicultura na região.

\section{CONCLUSÃO}

Conclui-se que é necessário um acompanhamento técnico a esses apicultores para que eles permaneçam em atividade e diminuam os casos de abandono de apiários. Não foram encontrados resíduos de agrotóxicos nas 20 amostras analisadas nesse estudo o que torna o mel produzido e extraído nas casas de mel nessa região seguro ao consumidor.

\section{AGRADECIMENTOS}

Agradecemos ao LARP - Laboratório de Análises de Resíduos de Pesticidas da UFSM, pela realização das análises cromatográficas.

\section{REFERÊNCIAS}

[1] Coronel, D. A., de Sousa, E. P., \& Amorim, A. L. (2011). Desempenho exportador do mel natural nos estados brasileiros. Pesquisa \& Debate. Revista do Programa de Estudos Pós-Graduados em Economia Política. ISSN 1806-311 9029, $22.2(40)$.

[2] Da Silva, E. A. (2010). Apicultura sustentável: produção e comercialização de mel no sertão sergipano (Dissertação de mestrado). Universidade Federal de Sergipe, São Cristóvão.

[3] De Queiroga, C. F. M. A., Leite Filho, F. G., Machado, A. V., \& de Oliveira Costa, R. (2015). Cadeia Produtiva do Mel de Abelhas: Fonte Alternativa de Geração de Renda para Pequenos Produtores e Qualidade Físico-química do Mel. Revista Brasileira de Agrotecnologia, 5(1), 24-30.

[4] Furlani, R. P. Z., Marcilio, K. M., Leme, F. M., \& Tfouni, S. A. V. (2011). Analysis of pesticide residues in sugarcane juice using QuEChERS sample preparation and gas chromatography with electron capture detection. Food chemistry, 126(3), 1283-1287.

[5] Gois, G. C., Rodrigues, A. E., de Lima, C. A. B., \& Silva, L. T. (2013). Composição do mel de Apis mellifera: Requisitos de qualidade. Acta Veterinaria Brasilica, 7(2), 137-147.

[6] Kurz, M. H., Martel, S., Gonçalves, F. F., Prestes, O. D., Martins, M. L., Zanella, R., \& Adaime, M. B. (2013). Development of a Fast Method for the 328 Determination of the Insecticide Fipronil and its Metabolites in Environmental Waters by SPE and GC-ECD. Journal of the Brazilian Chemical Society, 24(4), 631-638.

[7] Li, M., Liu, X., Dong, F., Xu, J., Kong, Z., Li, Y., \& Zheng, Y. (2013). Simultaneous determination of cyflumetofen and its main metabolite residues in samples of plant and animal origin using multi-walled carbon nanotubes in dispersive solid-phase extraction and ultrahigh performance liquid chromatography-tandem mass spectrometry. Journal of Chromatography A,1300, 95-103. 
[8] Moraes, F. J., Garcia, R. C., Vasconcelos, E., Camargo, S. C., Pires, B. G., Hartleben, A. M., \& Gremaschi, J. R. (2014). Caracterização físico-química de amostras de mel de abelha africanizada dos municípios de Santa Helena e Terra Roxa (PR). Arq. bras. med. vet. zootec, 66(4), 1269-1275.

[9] Orso, D. (2011). Determinação de resíduos de agrotóxicos em mel empregando Método QuEChERS modificado e GC-ECD. (Dissertação de mestrado). Universidade Federal de Santa Maria, Santa Maria.

[10] Orso, D., Martins, M. L., Donato, F. F., Rizzetti, T. M., Kemmerich, M., Adaime, M. B., \& Zanella, R. (2014). Multiresidue determination of pesticide residues in honey by modified QuEChERS method and gas chromatography with electron capture detection. Journal of the Brazilian Chemical Society, 25(8), 1355-1364.

[11] Pettis, J. S., Lichtenberg, E. M., Andree, M., Stitzinger, J., \& Rose, R. (2013). Crop pollination exposes honey bees to pesticides which alters their susceptibility to the gut pathogen Nosema ceranae. PLoS One, 8(7), e70182.

[12] Simionatto, M., Midori, E., \& Costa-Maia, F. M. (2012). Análises do Manejo e Comercialização Do Mel No Município De Dois Vizinhos-Paraná.

[13] Van der Sluijs, J. P., Simon-Delso, N., Goulson, D., Maxim, L., Bonmatin, J. M., \& Belzunces, L. P. (2013). Neonicotinoids, bee disorders and the sustainability of pollinator services. Current opinion in environmental sustainability, 5(3), 293-305.

[14] Wu, J. Y., Anelli, C. M., \& Sheppard, W. S. (2011). Sub-lethal effects of pesticide residues in brood comb on worker honey bee (Apis mellifera) development and longevity. PloS one, 6(2), e14720. 


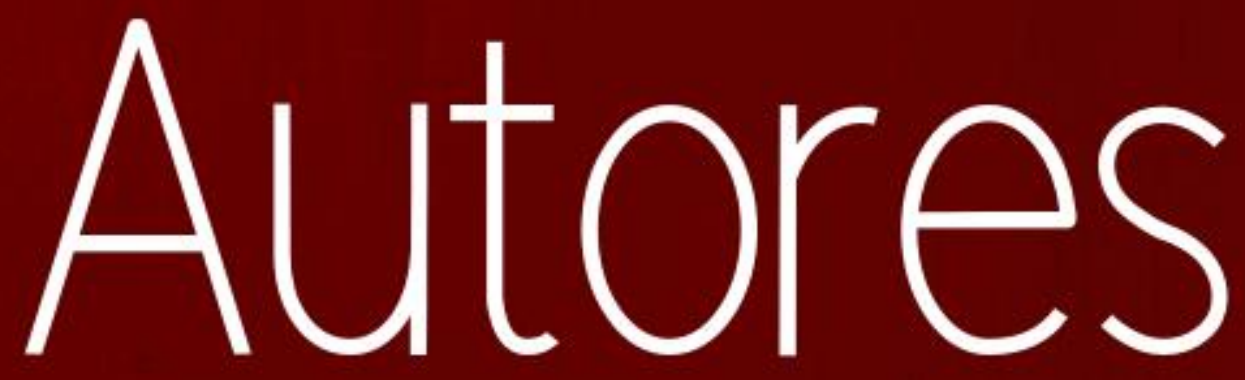




\section{AIANE BENEVIDE SERENO}

Graduada em Nutrição pela UNIBRASIL (2007-2011). Pós-graduada em Nutrição Clínica pela Faculdade Evangélica do Paraná (2011-2012). Mestre pelo Programa de Pós-Graduação em Alimentação e Nutrição do Setor de Ciências da Saúde da UFPR com ênfase em Qualidade dos Alimentos e Nutrição (2015-2017). Doutoranda do Programa de Pós-Graduação em Medicina Interna HC/UFPR (2018). Pesquisadora em frutos da biodiversidade brasileira e ensaio clínico in vivo em diabetes. Experiência como orientadora de trabalhos de conclusão de curso em pós graduação, Preceptora de estágios acadêmicos curriculares com integração teoria e pratica no campo de estágio. Docente com nutrição.

\section{ALAN HENRIQUE TEXEIRA}

Aluno do curso de Química industrial da Universidade Federal Da Paraíba. Atualmente no $6^{\circ}$ Período, Extensionista e pesquisador no laboratório de Análises e pesquisas de bebidas alcoólicas do Centro de Tecnologia/UFPB.

\section{ALESSANDRO DE LIMA}

Possui Graduação e Mestrado em Nutrição pela Universidade Federal de Pernambuco, Doutorado em Ciência dos Alimentos pela Universidade de São Paulo, com Doutorado Sanduíche na Universidade de Sevilla-Espanha e Pós Doutorado na Faculdade de Saúde Pública da USP. É Professor Titular com Dedicação Exclusiva do Instituto Federal de Educação, Ciência e Tecnologia do Piauí (IFPI) nos Cursos de Nutrição e Gastronomia. Pesquisador nas áreas de compostos bioativos, antioxidantes naturais, bioacessibilidade de polifenóis e caracterização nutricional de matérias primas regionais.

\section{ALEX BRITO SOUZA}

Graduado em Farmácia pela Universidade Federal do Pará (1998). Especialista em Analises Clínicas com Ênfase no Diagnóstico Laboratorial (UFPA/2005) e Gestão em Assistência Farmacêutica (UFSC/2012). Mestre em Biologia Parasitária na Amazônia (UEPA/IEC/2017). Atualmente é técnico em pesquisa e investigação biomédica do Instituto Evandro Chagas (IEC). Tem experiência na área de Analises Clinicas e Microbiológicas (com ênfase em Bacteriologia e Micologia).

\section{ALICE MONTEIRO DE OLIVEIRA}

Graduada em Bacharelado em Nutrição pela Faculdade Santo Agostinho de Teresina-FSA (2015), Especialização em Nutrição Clínica e Funcional pela Faculdade Santo Agostinho de Teresina-FSA (2017). Atualmente atua como nutricionista clínica funcional e nutricionista do PNAE.

\section{ALICE YOSHIKO TANAKA}

Possui graduação em Farmácia Bioquímica pela Faculdade de Farmácia e Odontologia de Araraquara (1969) e mestrado em Alimentos e Nutrição, na área de Ciências dos Alimentos pela Universidade Estadual Paulista Júlio de Mesquita Filho (1998). Doutorado em Biotecnologia, área Biotecnologia pelo Instituto de Química da Universidade Estadual Paulista Júlio de Mesquita Filho (2003). Atualmente é professor adjunto da FATEC - Faculdade de Tecnologia "Estudante Rafael Almeida Camarinha", na cidade de Marília. Tem experiência na área de Microbiologia, com ênfase em Microbiologia Industrial e de Fermentação, atuando principalmente nos seguintes temas: condições higiênico-sanitárias, sorvetes, s aureus, microbiologia e h aegyptius. 


\section{AMANDA CRISTINA ALFREDO CONTRUCCI SORBO}

Graduada em Engenharia Química, pela Universidade Estadual de Maringá (2008), pós graduada em Engenharia de Produção, pela Uninter (2012) e mestra em Energia na Agricultura, pela UNESP, campus Botucatu/SP (2017). Atualmente, docente do Centro Universitário Sudoeste Paulista (UniFSP) nas disciplinas de Processos Produtivos, Sistemas de Produção, Gestão de Qualidade, Controle Estatístico de Qualidade, Métodos Numéricos, Organização do Trabalho, Cálculo I/II e III, Geometria Analítica, Tecnologia e Sociedade, TCC e Ergonomia para Engenharia de Produção, Agronômica e Civil.

\section{ANA CIBELE PEREIRA SOUSA}

Mestra em Alimentos e nutrição - UFPI, Especialista em Nutrição e controle de qualidade de alimentos (INTA), Graduada em nutrição pela Universidade Federal do Piauí - UFPI, Campus Senador Helvideo Nunes de Barros - CSHNB, Picos - PI, (2014). Professora substituta UFPI -CSHNB

\section{ANDRÉ MARCELO KNAK}

Tecnólogo em Alimentos pelo SENAI Toledo

\section{ANELI DE MELO BARBOSA DEKKER}

Graduada em Farmácia e Bioquímica pela Universidade Estadual de Londrina (UEL) em agosto de 1978, Mestre em Ciências (Bioquímica) pela Universidade Federal do Paraná (UFPR) em 1984, Doutora em Ciências (Bioquímica) pela UFPR em 1992, Pós-Doutora na Universidade de Murdoch School of Biological and Environmental Sciences (1994 -1995) em Perth, Austrália, Pós-Doutora, na Universidad Castilla de La Mancha, em Ciudad Real na Espanha, atualmente trabalha como Professora Senior, dando continuidade a sua carreira cientifica. Bolsista Senior da Fundação Araucaria Edital 09/2015.

\section{ANNA CLAUDIA SAHADE BRUNATTI}

Graduada em Nutrição pela Universidade de Marília (1998), Mestre em Agronomia pela Universidade de Marília (2008) e Doutora em Agronomia pela UNESP de Botucatu (2016). Docente de Graduação e Pós Graduação, em Regime de Jornada Integral, na FATEC "Estudante Rafael Almeida Camarinha" - Marília/SP, curso Superior em Tecnologia de Alimentos. Tem experiência na área de Ciência e Tecnologia de Alimentos, com ênfase em Tecnologia de Produtos de Origem Vegetal, atuando principalmente nos seguintes temas: Tecnologia em Alimentos, Tecnologia de Amido e Produtos Amiláceos, Pesquisa e Desenvolvimento de Novos Produtos e Nutrição Esportiva.

\section{ANTONIO MULET}

Catedrático de Universidade no Departamento de Tecnología de Alimentos da Universitat Politècnica de València (UPV) desde 1990. Atua principalmente na modelagem e simulação de processos de transferência de massa e calor, incluindo processos de secagem, tratamentos térmicos e aplicação de fluidos supercríticos. Além disso, possui conhecimento na aplicação de ultrassom de sinal e de potência como ferramenta para melhorar tais processos.

\section{BRUNA BARBOSA DE ABREU}

Aluna de graduação do curso de Nutrição da Universidade Federal do Piauí-UFPI. Bolsista de Iniciação Tecnológica do PIBIT-UFPI. 


\section{CAMILA GAIO}

Possui graduação em Tecnologia em Alimentos pela Universidade Tecnológica Federal do ParanáCampus Medianeira e Especialização Lato Sensu em Avicultura Industrial, pela Pontifícia Universidade Católica do Paraná (PUCPR). Vasta experiência na indústria de alimentos com enfase em frango de corte e industrialização de carnes.

\section{CASSANDRA MEIRELES TERRES RIBEIRO}

Possui graduação em Tecnologia em Industrialização de Carnes pela Universidade Tecnológica Federal do Paraná (2008). Possui especialização em Microbiologia Aplicada pela Universidade Estadual do Oeste do Paraná -Unioeste- (2011). Mestre em Ciência de Alimentos pela Universidade Estadual de Maringá - UEM - . Tem experiência na área de Ciência e Tecnologia de Alimentos, com ênfase em Ciência e Tecnologia de Alimentos.

\section{CLARA DOS REIS NUNES}

Doutora (2015) e Mestre (2011) em Produção Vegetal com ênfase em Química de Alimentos na Universidade Estadual do Norte Fluminese Darcy Ribeiro - UENF, especialista em Análises Clínicas e Gestão de Laboratórios pela Faculdade de Medicina de Campos - FMC (2010)e graduada em Biologia pela Universidade Estadual do Norte Fluminense Darcy Ribeiro - UENF (2008). Possui experiência na área de Química e Imunofarmacologia, atuando principalmente com metabolismo vegetal, alimentos funcionais, graviola (Annona muricata L.), processo inflamatório e antitumoral, técnicas cromatográficas e análises físico-químicas. Atualmente é docente na Faculdade Redentor no curso de Nutrição e Enfermagem em Campos dos Goytacazes (RJ), onde atua também como membro do Núcleo Docente Estruturante (NDE) e do Colegiado do curso de Enfermagem. Além disso, é docente na Faculdade Metropolitana São Carlos em Bom Jesus do Itabapoana (RJ) nos cursos de Medicina, Ciências Biológicas, Enfermagem e Administração, bem como membra do NDE de Enfermagem e Biologia, além de Coordenadora do Comitê de Ética em Pesquisa (CEP).

\section{CLAUDIA CARNEIRO HECKE KRUGER}

Possui graduação em Nutrição pela UFPR (1989), mestrado em Tecnologia de Alimentos (2002) e doutorado no Programa de Pós Graduação em Tecnologia de Alimentos da UFPR (2006). Atualmente é professora Associada na Universidade Federal do Paraná e Coordenadora do Programa de Pós-Graduação em Alimentação e Nutrição. Atua nos seguintes temas: propriedades funcionais e fisiológicas de alimentos e matérias-primas alimentícias, leite bovino, caseinatos, soro de leite e caseinofosfopeptídeos, alfarroba, produtos lácteos com teor reduzido de lactose, qualidade nutricional de frutos da biodiversidade brasileira.

\section{CLAUDIO TAKEO UENO}

Graduado em Farmacia e Bioquimica pela UEL, Mestre em Microbiologia pela Universidade Estadual de Londrina (UEL) em 1996. Doutor em Ciência de Alimentos pela Universidade Estadual de Londrina (UEL) em 2007, Atualmente é professor de ensino básico, técnico e tecnológico da Universidade Tecnológica Federal do Paraná (UTFPR) - Campus de Londrina lecionando disciplina de bioquímica e microbiologia, no curso superior de tecnologia em alimentos.

\section{CLEISE DE OLIVEIRA SIGARINI}

Médica Veterinária formada pela Universidade Federal de Mato Grosso - UFMT (2001), com Especialização em Controle de Qualidade de Alimentos pela Universidade Federal de Lavras - UFLA (2003); Mestrado em Medicina Veterinária pela Universidade Federal Fluminense - UFF (2004) e Doutorado em Zootecnia pela Faculdade Estadual Paulista Júlio de Mesquita Filho - UNESP Campus de Botucatu (2009). Experiência profissional como Responsável Técnica em Indústria de Produtos de Origem Animal; Docência em Instituições de Ensino Superior (pública e privada) e Médica veterinária concursada do Serviço de Inspeção Municipal (SIM) de Cuiabá. Atualmente 
Professora efetiva do Curso de Ciência e Tecnologia de Alimentos da Universidade Federal de Mato Grosso - UFMT. Área de atuação: Tecnologia de Carnes e Derivados.

\section{CLÓVIS GOUVEIA DA SILVA}

Técnico em Agropecuária - Engenheiro de Alimentos - Mestre Engenharia Agrícola Doutor em Engenharia de Processos - Pesquisa as potencialidades biotecnológicas da algarobeira.

\section{CLOVIS QUEIROZ GOUVEIA}

Estudante de Biotecnologia pela Universidade Federal da Paraíba, realiza experimentos no laboratório de Análises e pesquisas de bebidas alcoólicas do Centro de Tecnologia/UFPB.

\section{CRISTINA JANSEN ALVES}

Possui graduação em Química de Alimentos pela Universidade Federal de Pelotas (2011), mestrado em Nutrição e Alimentos (2015) e doutorado em Ciência e Tecnologia de Alimentos (2018), ambos pela mesma instituição. Tem experiência em Ciência e Tecnologia de Alimentos, atuando principalmente em tecnologia de produtos de origem animal, processamento de frutos e hortaliças e microencapsulação. Atualmente é professora substituta do Departamento de Tecnologia e Ciência de Alimentos da Universidade Federal de Santa Maria.

\section{DENISE PASTORE DE LIMA}

Possui graduação em Tecnologia de Alimentos pelo Centro Federal de Educação Tecnológica (2000), mestrado em desenvolvimento regional e agronegócio pela Universidade Estadual do Oeste do Paraná (2005) e Doutorado em Ciência de Alimentos pela Universidade Estadual de Maringá - UEM (2015). Atualmente é professora da Universidade Tecnológica Federal do Paraná, atuando nos cursos de Engenharia de Alimentos e Tecnologia em Alimentos e professora no Programa de Especialização em Gestão Ambiental em Municípios na mesma instituição. Tem experiência na área de ciência de alimentos, atuando principalmente nos seguintes temas: Tecnologia de carnes e pescado, qualidade e segurança do alimento e microbiologia.

\section{DIEGO SORGE}

Possui graduação em Programa de Formação de Professores da Educação Básica - Química pela Universidade Estadual de Londrina (2005) e mestrado em Tecnologia de Alimentos pela Universidade Tecnológica Federal do Paraná (2015). Atualmente é analista do controle de qualidade - Cia Cacique de Café Solúvel.

\section{EDIVALDO SAMPAIO DE ALMEIDA FILHO}

Possui graduação em Medicina Veterinária pela Universidade Federal Rural da Amazônia (1994) Campus de Belém, especialização em Inspeção de Alimentos pela UNESP Campus de Botucatu (1996), mestrado em Medicina Veterinária Preventiva, pela UNESP Campus de Jaboticabal (1998) e doutorado em Medicina Veterinária (Higiene Veterinária e Processamento Tecnológico de Produtos de Origem Animal) pela Universidade Federal Fluminense (2006). Atualmente é professor adjunto 4 da Faculdade de Agronomia, Medicina Veterinária e Zootecnia (FAMEVZ) da Universidade Federal de Mato Grosso, Campus de Cuiabá. Tem experiência na área de Medicina Veterinária, com ênfase em Higiene e Tecnologia de Pescado, atuando no ensino de graduação nas disciplinas de Tecnologia de Produtos de Origem Animal e Inspeção de Produtos de Origem Animal, pós-graduação ao nível de mestrado, na disciplina de Tópicos em Microbiologia de Alimentos, e pós-graduação ao nível de doutorado na disciplina de Higiene e Tecnologia de Pescado e Derivados. Participa do Núcleo de Estudos em Pescado (NEPES), vinculado à FAMEVZUFMT, orienta no Programa de Pós Graduação em Ciência Animal (4 Capes) PPGCA, pesquisas envolvendo organismos indicadores de qualidade higiênico-sanitária em pescado fresco e congelado, desenvolvimento de produtos derivados de pescado, e desenvolvimento da técnica de 
medição de índice de qualidade (MIQ) em peixes da região do pantanal matogrossense e da bacia amazônica.

\section{EDUARDO SOUSA DOS ANJOS}

Mestrando em Ciência e Tecnologia de Alimentos - Universidade Federal do Tocantins/UFT e especialização em Tecnologia e Processamento de Produtos de Origem Animal Carne, Leite e Ovos pela Universidade Federal de Lavras/UFLA. Atualmente é Técnico do Laboratório de Tecnologia de Carnes e Derivados do Campus de Palmas - UFT.

\section{ELAINE PATRÍCIA TAVARES DO ESPÍRITO SANTO}

Graduada em Farmácia Generalista pelo Centro Universitário do Estado do Pará (2009). Mestre em Biologia de Agentes Infecciosos e Parasitários pela Universidade Federal do Pará (UFPA). Especialista em Farmacologia pela Faculdade de Farmácia do Instituto de Ciências da Saúde da UFPA. Experiência na área de Microbiologia, com ênfase em Micologia Médica. Doutoranda em Biologia de Agentes Infecciosos e Parasitários pela UFPA. Atualmente Técnica em Pesquisa e Investigação Biomédica no Laboratório de Micologia do IEC, atuando no diagnóstico sorológico de infecções fúngicas; pesquisas relacionadas a leveduras do gênero Candida e Trichosporon; biologia molecular de leveduras de interesse clínico; e estudos relacionados à avaliação do potencial antifúngico de compostos e bioativos oriundos de espécimes botânicos da Região Amazônica.

\section{ELIEZER AVILA GANDRA}

Possui graduação em Engenharia de Alimentos pela FURG (2001), mestrado em Ciência e Tecnologia Agroindustrial (2003) e doutorado em Ciência e Tecnologia Agroindustrial (2006) ambos pela UFPel. Atualmente é Professor Associado do Centro de Ciências Químicas, Farmacêuticas e de Alimentos e docente permanente do Programa de Pós Graduação em Nutrição e Alimentos e do Mestrado Profissional em Ciência e Tecnologia de Alimentos ambos da UFPel. Foi coordenador do curso de Bacharelado em Química de Alimentos (UFPEL) e do curso de Tecnologia em Alimentos (UEM). Tem experiência na área de Ciência e Tecnologia de Alimentos, com ênfase em Microbiologia de Alimentos, Biotecnologia e Ciência e Tecnologia de Produtos de Origem Animal.

\section{EVELY DEGRAF TERRA PARCKERT}

Possui graduação em Engenharia de Alimentos pela Faculdades Associadas de Uberaba - FAZU (2005), mestrado em Engenharia Química pela Universidade Federal de Uberlândia - UFU (2009) e doutorado em Engenharia Química pela Universidade Federal de Uberlândia - UFU (2014). Exerce suas atividades de pós-doutorado na Universidade Federal do Triângulo Mineiro - UFTM, desenvolvendo pesquisa relacionada à concentração de Azadiractina $\mathrm{A}$ de folhas e frutos de Nim (Azadirachta indica). Tem experiência na área de Ciência e Tecnologia de Alimentos atuando principalmente nos seguintes temas: secagem de espécies vegetais, separação, extração e caracterização de compostos biologicamente ativos.

\section{FERNANDA DORING KRUMREICH}

Graduada em Bacharelado em Química de Alimentos pela Universidade Federal de Pelotas - UFPEL - Pelotas/RS, com mestrado e doutorado em Ciência e Tecnologia de Alimentos, na área de Ciência e Tecnologia de Frutos e Hortaliças também pela UFPEL. Educadora na Escola Família Agrícola da Região Sul (EFASUL). 


\section{FERNANDA VANESSA NETTO ARAGÃO}

Mestranda em Desenvolvimento Rural e Gestão de Empreendimentos Agroalimentares pelo Instituto Federal de Educação, Ciência e Tecnologia do Pará - Campus Castanhal -IFPA. Especialista em Gestão de Projetos pelo Programa de Pós-Graduação da Universidade da Amazônia - UNAMA (2018). Tecnóloga de Alimentos formada pela Universidade do Estado do Pará - UEPA (2015). Com experiência nas áreas de controle de qualidade e pesquisa e desenvolvimento de novos produtos em indústrias alimentícias.

\section{FLAVIA MARIA VASQUES FARINAZZI-MACHADO}

Graduada em Nutrição pela Universidade de Marília (1999), Especialista em Nutrição Clinica, pela UNESP, de Botucatu (2001), Mestre em Ciência e Tecnologia de Alimentos - Escola Superior de Agricultura Luiz de Queiróz (USP) (2003) e Doutora pela UNESP, de Botucatu (2018). Atual docente e pesquisadora em Regime de Jornada Integral, da Fatec Estudante Rafael Almeida Camarinha - Curso Superior em Tecnologia de Alimentos, nas disciplinas de Nutrição e Tecnologia de Produtos Açucarados. Membro do Comitê de Ética em Humanos da Faculdade de Tecnologia de Marília-SP. Professora orientadora e pesquisadora em Alimentos funcionais na prevenção de doenças crônico-degenerativas (obesidade, diabetes, doenças cardiovasculares). Atua ainda nas seguintes linhas de pesquisa: (1) Diagnóstico e intervenção em nutrição e saúde nos diferentes ciclos da vida e (2) Qualidade funcional e inovação em produtos açucarados com apelo de saudabilidade, como barras de cereais, geleias diet e light, drageados e chocolates.

\section{FRANCIS JOSÉ ZORTÉA MERINO}

Possui Graduação em Tecnologia em Química Ambiental pela Universidade Tecnológica Federal do Paraná (2010), graduação em Farmácia pela Universidade Federal do Paraná (2013) e Mestrado em Ciências Farmacêuticas pela Universidade Federal do Paraná (2014). Durante o Mestrado atuou na área de pesquisa de insumos, medicamentos e correlatos, com ênfase em fitoquímica, química de produtos naturais, isolamento e identificação de substâncias, avaliação de atividade antioxidante, antibacteriana, toxicidade e atividade alelopática de extratos vegetais. Doutor em Ciências Farmacêuticas pela Universidade Federal do Paraná (2018) com o projeto de pesquisa sobre atividades biológicas e avaliação farmacológica dos extratos e compostos isolados de espécies vegetais.

\section{FRANCISCO ADALBERTO DO NASCIMENTO PAZ}

Possui graduação em Ciências Biológicas pela Universidade Federal do Piauí (2000). Mestre em Genética e Toxicologia Aplicada (2012) pela Universidade Luterana do Brasil - ULBRA-RS. Doutorado em Biologia Celular e Molecular Aplicada a Saúde (2017). Professor no Centro Universitário Santo Agostinho (UNIFSA) nos cursos de saúde e tem experiência na área de docência.

\section{GABRIELA VIGNERON AGUIAR}

Técnica em Química pelo Instituto Federal Fluminense (2012). Possui graduação em Farmácia pela Faculdade de Medicina de Campos (2016). Atualmente faz mestrado em Ciências Naturais pela Universidade Estadual do Norte Fluminense Darcy Ribeiro (UENF).

\section{GARDENE DOURADO MOTA}

Graduada em Biomedicina pela Universidade Federal do Pará (2002). Mestre em Biologia Parasitaria na Amazônia pela Universidade estadual do Pará (2018),especialização em Citologia Clínica com ênfase no trato genital feminino pelo Centro Universitário do Estado do Pará-CESUPA (2015) e especialização em Microbiologia Médica pelo IPESSP-SP (2008) .Experiência em hematologia, análise seminal, bioquímica, urinálise e microbiologia. Atualmente trabalha como Técnico em Pesquisa e Investigação Biomédica no Laboratório de Infecções sexualmente transmissíveis e tracoma (IST/Tracoma) no Instituto Evandro Chagas (IEC-PA). 


\section{GIOVANNA MAZOTI CRUBELATI}

Formada em Engenharia de Alimentos (2013 - 2017) pela Universidade Estadual de Maringá, Umuarama - PR. Estágio obrigatório na empresa GTFoods em Terra Boa - PR, 2017 e atualmente trabalha na empresa Seara, Rolândia - PR.

\section{GREIKA FERREIRA MOURA}

Graduada em Medicina Veterinária pela Universidade de Cuiabá - UNIC (2013). Mestre em Ciência Animal pela Universidade Federal de Mato Grosso (2016), com ênfase em microbiologia e aplicação de técnicas moleculares para identificação de microrganismos de interesse para alimentos. Possui experiência na área de Microbiologia, com ênfase em Microbiologia Geral e Microbiologia de Alimentos, e na área de Ciência e Tecnologia de Alimentos, com ênfase em produtos de origem animal. Atualmente é doutoranda em Ciência Animal, trabalhando em temas como qualidade higiênico-sanitária de pescado fresco e congelado e desenvolvimento de produtos e coprodutos de pescado.

\section{HELOÍSA THEODORO}

Graduada em Nutrição pela Universidade de Caxias do Sul (2008). Mestre em Saúde Coletiva pela Universidade do Vale do Rio dos Sinos (2011). Doutorado sanduíche (2018-2019) University of Toronto - Canada. Doutoranda em Saúde Coletiva pela Universidade do Vale do Rio dos Sinos. Atualmente é professora assistente da Universidade de Caxias do Sul. Atuando principalmente nos seguintes temas: Saúde Coletiva e Nutrição.

\section{IANGLA ARAÚJO DE MELO DAMASCENO}

Possui graduação em Farmácia Generalista pelo Instituto Tocantinense Presidente Antônio Carlos ITPAC (2013). Mestre em Ciência e Tecnologia de Alimentos (UFT/2016). Especialista em Docência Universitária (ITPAC/ 2015); Especialista em Gestão de Assistência Farmacêutica (UFSC/ 2015). Tem experiência na área de Microbiologia, atuando principalmente nos seguintes temas: micologia, testes de sensibilidade, microbiologia de Alimentos. Conteudista e Tutor on line da Disciplina de Atenção Primária à Saúde, Gestão e Politicas Públicas do UNITPAC e NRE Educacional

\section{ISABEL CRAVEIRO MOREIRA ANDREI}

Possui graduação em Engenharia Química pela Universidade Federal Rural do Rio de Janeiro (1991), mestrado em Química pela Universidade Federal Rural do Rio de Janeiro (1994) e doutorado em Química Orgânica pela Universidade de São Paulo (1999). Atualmente é professora de ensino básico, técnico e tecnológico da Universidade Tecnológica Federal do Paraná. Tem experiência na área de Química, com ênfase em Química dos Produtos Naturais, atuando principalmente nos seguintes temas: atividade antioxidante, produtos naturais, funcionalidade de alimentos.

\section{IVANILTON ALMEIDA NERY}

Possui graduação em ENGENHARIA QUíMICA - Departamento de Tecnologia Química (1993) e mestrado em Ciência e Tecnologia de Alimentos pela Universidade Federal Rural do Rio de Janeiro (1996). Trabalhou como docente do curso técnico em alimentos no CTS Alimentos e Bebidas, em Vassouras (RJ) de 2008 a 2013. Atualmente é Professor de Ensino Básico, Técnico e Tecnológico do Instituto Federal de Educação, Ciência e Tecnologia do Rio de Janeiro (Unidade Nilópolis), ministrando aulas de Bioquímica e de Processos Bioquímicos. Tem experiência na área de Microbiologia de Alimentos, Microbiologia Industrial e Bioprocessos, atuando principalmente nos seguintes temas: fermentação, fungos, leveduras, produção de enzimas, produção de bebidas fermentadas e outros processos bioquímicos. Coordenador do curso de Bacharelado em Química desde maio de 2017 até o presente momento. 


\section{JAVIER TELIS ROMERO}

Técnico em Eletrônica pelo Instituto Tecnologico de Orizaba - México (1979), Graduação em Engenharia Química - Universidad Veracruzana - México (1984), Mestrado e Doutorado em Engenharia de Alimentos (UNICAMP - 1992). Pós-Doutorado - Aplicação de ultrassom em processos alimentícios, Universidad Politecnica de Valencia - España (2007-2008), Professor Titular em Engenharia de Processos (2012) na Universidade Estadual Paulista "Júlio de Mesquita Filho" (IBILCE/UNESP). Oferece as disciplinas de Operações Unitárias I e II, Sistemas Particulados, Fenômenos de Transporte I e Reologia. Trabalha com linhas de pesquisa de Fenômenos de Transporte e Operações Unitárias no processamento de alimentos.

\section{JOÃO BATISTA BARBOSA}

Tecnólogo em Laticínios pelo IF Sudeste MG Campus Rio Pomba (2006-2008). Mestre em Produção Vegetal/Tecnologia em Alimentos pela Universidade Estadual do Norte Fluminense Darcy Ribeiro UENF (2009-2011). Doutor em Produção Vegetal/Tecnologia em Alimentos pela Universidade Estadual do Norte Fluminense Darcy Ribeiro - UENF (2011-2015). Atualmente é professor na área de Alimentos do Instituto Federal de Sergipe - IFS Campus Glória. Atua na área Tecnologia de Alimentos e Tecnologia de Laticínios, Microbiologia Geral, Microbiologia de Alimentos, Microbiologia Industrial, Controle de Qualidade dos Alimentos, Educação/Ensino, Interdisciplinar.

\section{JOELMA MOREIRA ABREU}

Possui graduação em Licenciatura em Química pela Universidade Federal do Piauí (2005). Mestrado em Química pela Universidade Federal do Piauí (2008). Doutorado em Biotecnologia pelo renorbio (2017). Docente do Centro Universitário Faculdade Santo Agostinho (UNIFSA).

\section{JOSÉ ROBERTO DELALIBERA FINZER}

Possui graduação em Curso de Engenharia Química pela Universidade Federal de Uberlândia (1973), mestrado em Engenharia de Alimentos pela Universidade Estadual de Campinas (1984) e doutorado em Engenharia de Alimentos pela Universidade Estadual de Campinas (1989). Atualmente é professor do Curso de Graduação em Engenharia Química: Universidade de UberabaUNIUBE e Coordenador do Curso de Mestrado Profissional em Engenharia Química. Ex- Professor do Programa de Pós-Graduação e de Graduação em Engenharia Química da Universidade Federal de Uberlândia - Ex-Bolsista do CNPq da Universidade Federal de Uberlândia - Produtividade em Pesquisa. Ex-Professor do Curso de Engenharia de Alimentos da Universidade Regional Integrada do Alto Uruguai e das Missões (Erechim-RS). Ex- Professor do Curso de Engenharia de Alimentos das Faculdades Integradas- FAZU (Uberaba-MG). Tem experiência na área de Engenharia Química e Engenharia de Alimentos, com ênfase em Operações Industriais e Equipamentos para Indústrias Alimentícias e Químicas, atuando principalmente nos seguintes temas: secagem, cristalização: sacarose e ácido cítrico, secagem de materiais pastosos e secagem com inertes; secagem de café e grãos; transferência de calor e massa em sistemas vibrados, produção de sacarose, fabricação de biodiesel, balanço de massa e de energia.

\section{JUAN A. CÁRCEL}

Catedrático de Universidade no Departamento de Tecnología de Alimentos da Universitat Politècnica de València (UPV). Possui pesquisas voltadas para o controle e melhora de processos, considerando modelagem matemática como ferramenta necessária para tomada de decisões. $\mathrm{Na}$ área de controle de processo, destaca-se os trabalhos sobre a aplicação de ultrassom de sinal como técnica não-destrutiva e não-invasiva para caracterização da composição, estrutura e textura de alimentos. Na melhora de processos, suas atividades estão voltadas para a aplicação de ultrassom de alta intensidade para intensificação de processos, especialmente na secagem. 


\section{JULIANA BUENO RUIZ}

Possui graduação em Ciências Biológicas Com Ênfase Em Biotecnologia pela Universidade Paranaense (2004) e mestrado em Genética e Melhoramento pela Universidade Estadual de Maringá (2006). Doutora em Genética e Melhoramento pela Universidade Estadual de Maringá, professora da Universidade Estadual de Maringá (Professor Assistente). Especialização em Educação Inclusiva pelo IESDE e Especialização em Gestão Ambiental nos Municípios pela UTFPR. Tem experiência na área de Genética, com ênfase em Genética Animal, Gestão Ambiental e Ciências e Tecnologia dos Alimentos.

\section{JULIANA CORDEIRO DA SILVA}

Graduanda do curso de Bacharelado em Química pelo IFRJ campus Nilópolis.

\section{JULIANA ROMBALDI BERNARDI}

Possui graduação em Nutrição pela Universidade do Vale do Rio dos Sinos (UNISINOS, 2006, São Leopoldo-RS), mestrado em Ciências da Saúde pela Universidade Federal de Ciências da Saúde (UFCSPA, 2010, Porto Alegre-RS) e doutorado em Saúde da Criança e do Adolescente pela Universidade Federal do Rio Grande do Sul (UFRGS, 2013, Porto Alegre-RS). Atualmente é coordenadora e professora adjunta do curso de Nutrição (UFRGS), docente do Programa de PósGraduação em Saúde da Criança e do Adolescente (UFRGS) e do Programa de Pós-Graduação Alimentação, Nutrição e Saúde, integrante do Grupo de Pesquisa NESCA (Núcleo de Estudos da Criança e do Adolescente).

\section{JULIANNA MATIAS VAGULA}

Nutricionista. Doutora em Ciências de Alimentos (UEM). Mestre em Ciências de Alimentos (UEM). Bacharel em Nutrição pela Universidade Norte do Paraná (2008). Especialista em Nutrição nos Ciclos da Vida (PUCPR). Especialista em Gestão Pública da Saúde (UAB/UNICENTRO).

\section{KARINA DA SILVA FALCÃO}

Estudante de Química Industrial pela Universidade Federal da Paraíba, extensionista e pesquisadora no laboratório de Análises e pesquisas de bebidas alcoólicas do Centro de Tecnologia/UFPB.

\section{LETÍCIA GABRIELA POZZER PIRES}

Mestre pelo programa de pós-graduação da Ciência Animal, linha de pequisa - Higiene e Tecnologia de Alimentos pela Universidade Federal de Mato Grosso, campus Cuiabá (2018). Graduada em Engenharia de Alimentos pelo Centro Universitário de Várzea Grande - UNIVAG (2016). Ministrando aulas em temas como Assistente administrativo, Encarregado de produção e processos industriais; Tecnologia de frutas e hortaliças, Apicultura, Piscicultura, Qualidade higiênico-sanitária do pescado, Reutilização e criação de novos produtos e coprodutos a partir de resíduos gerados pela indústria de pescado; Aplicação da Cinética de Secagem.

\section{LUCIA FELICIDADE DIAS}

Possui graduação em Química pela Universidade Estadual de Maringá (1990), mestrado em Química pela Universidade Estadual de Maringá (1995) e doutorado em Química pela Universidade Federal de Santa Catarina (2004). Atualmente é professor EBTT nivel D4 da Universidade Tecnológica Federal do Paraná. Tem experiência na área de Ciência e Tecnologia de Alimentos, com ênfase em Avaliação e Controle de Qualidade de Alimentos, atuando principalmente nos seguintes temas: absorção atômica, composição proximal de alimentos. 


\section{LUCIANA GIBBERT}

Possui graduação em Nutrição pela Universidade Federal da Fronteira Sul- UFFS (2014) e mestrado em Alimentação e Nutrição pela Universidade Federal do Paraná-UFPR (2017). Atualmente é doutoranda em Ciências Farmacêuticas na Universidade Federal do Paraná, trabalhando na área de produtos naturais. Atua principalmente nos seguintes temas: tecnologia de alimentos, nutrição experimental, controle e qualidade de alimentos, Diabetes mellitos, produtos naturais, ciências farmacêuticas e biodiversidade brasileira.

\section{LUIS EDUARDO SILVA NASCIMENTOS}

Doutorando em Ciência de Alimentos pela Faculdade de Engenharia de Alimentos da Universidade Estadual de Campinas, UNICAMP. Mestre em Ciência dos Alimentos pela Universidade Federal de Santa Catarina, UFSC. Tecnólogo de Alimentos formado pela Universidade do Estado do Pará, UEPA. Atua na área de Ciência e Tecnologia de Alimentos com ênfase na área de análise e química de alimentos de origem vegetal.

\section{LUÍZA MARLY FREITAS DE CARVALHO}

Possui graduação em nutrição pela Univesidade Federal do Piauí (2006). Graduada em Educação Física pela Universidade Federal do Piauí (1997). Mestrado em Alimentos e Nutrição pela Universidade Federal do Piauí (2012). Doutorado no Programa de Alimentos e Nutrição - PPGANUFPI. Docente do Centro Universitário Faculdade Santo Agostinho (UNIFSA).

\section{MARCOS ANTÔNIO DA MOTA ARAÚJO}

Graduado em Estatística pela Universidade Católica de Pernambuco-UNICAP. Especialista em Análise de Dados na Área de Saúde pela Universidade Federal de Pernambuco-UFPE.

\section{MARINA CORREA DA COSTA ABREU}

Bacharel em Ciência e Tecnologia de Alimentos e Mestre em Ciência Animal pela Universidade Federal de Mato Grosso (UFMT), desenvolvi minha experiência acadêmica e prática na área química e de alimentos, com experiência em análises físico-químicas e microbiológicas e seus impactos na saúde pública.

\section{MARLENE BAMPI}

Possui graduação em Engenharia de Alimentos pela Universidade Estadual do Centro-Oeste (2007), Mestrado pela Universidade Federal do Paraná (2011) e Doutorado em Engenharia de Alimentos pela Universidade Federal de Santa Catarina (2015). Atualmente é professora do Departamento de Engenharia de Alimentos e Engenharia Química da Universidade do Estado de Santa Catarina. Tem experiência com processos de secagem e determinação de compostos fenólicos e antioxidantes.

\section{MAURÍCIO EDUARDO MATOS CAVALCANTE}

Possui graduação em Gastronomia pelo Instituto Federal do Piauí (2015). Tem experiência na área de Ciência e Tecnologia de Alimentos

\section{MAURISRAEL DE MOURA ROCHA}

Possui graduação em Engenharia Agronômica pela Universidade Federal do Piauí (1995), mestrado (1998) e doutorado (2002) em Genética e Melhoramento de Plantas pela Escola Superior de Agricultura Luiz de Queiroz Universidade de São Paulo. Atualmente é pesquisador A da Empresa Brasileira de Pesquisa Agropecuária-EMBRAPA Meio-Norte e professor permanente dos 
cursos de Pós-graduação em Genética e Melhoramento e de Alimentos e Nutrição da Universidade Federal do Piauí-UFPI

\section{MAYKON JHULY MARTINS DE PAIVA}

Possui Graduação em Farmácia Generalista pelo Centro Universitário Instituto Tocantinense Presidente Antônio Carlos. (UNITPAC) Especialização Latu Sensu em Biotecnologia pela Universidade Católica Dom Bosco (UCDB). Mestrando do Programa de Pós-graduação em Ciência e Tecnologia dos Alimentos na Universidade Federal do Tocantins (UFT).

\section{MIRLA DE NAZARÉ DO NASCIMENTOS MIRANDA}

Graduação em Engenharia Química pela Universidade Federal do Pará, Mestrado e Doutorado em Engenharia Química, pela Universidade Estadual de Campinas - UNICAMP. Professora Adjunto IV, lotada no Departamento de Tecnologia de Alimentos - DETA, do Centro de Ciências Naturais e Tecnologia - CCNT, da Universidade do Estado do Pará.

\section{MYRELLA PEREIRA PINTO}

Possui formação como técnica de agroindústria/alimentos pelo Instituto Federal do Maranhão, e graduação em Gastronomia pelo Instituto Federal do Piauí (2017). Tem experiência na área de Ciência e Tecnologia de Alimentos, com ênfase em Ciência e Tecnologia de Alimentos, atuando principalmente nos seguintes temas: arroz, farelo, reaproveitamento., compostos bioativos, antioxidante, flavonoides e facheiro.

\section{NARA VANESSA DOS ANJOS BARROS}

Nutricionista, Professora Assistente do Curso de Nutrição (CSHNB/UFPI), Doutoranda e Mestre em Alimentos e Nutrição, linha de pesquisa Qualidade de Alimentos do PPGAN da Universidade Federal do Piauí - UFPI. Tem experiência na grande área de Alimentos e Nutrição, com ênfase em Bromatologia e Bioquímica de Alimentos, Estudo Experimental e Análise Sensorial de Alimentos, Desenvolvimento de Produtos, Nutrição Funcional e Intervenções Nutricionais.

\section{PATRÍCIA BINZ}

Possui graduação em Nutrição pela Universidade de Caxias do Sul (UCS, 2014). Pós-graduação em Gestão de Marcas pela UCS. Mestre em Turismo e Hospitalidade, com o tema Gastronomia Sustentável, também pela UCS. Atualmente é consultora, na área de segurança de alimentos, docente nos cursos de gastronomia e de estética, além de ser coordenadora do curso de gastronomia pelo Centro Universitário e Faculdades UNIFTEC. Tem experiência na área de Nutrição, com ênfase em segurança de alimentos e sustentabilidade nos serviços alimentares. Possui formação complementar na área de bebidas, sendo nível 2 Wine \& Spirits Education Trust e Sommelier em formação pela ABS.

\section{REGILDA SARAIVA DOS REIS MOREIRA-ARAÚJO}

Possui graduação em Nutrição pela Universidade Federal do Piauí (1988), mestrado em Tecnologia de Alimentos pela Universidade Federal do Ceará (1995) e doutorado em Ciência de Alimentos São Paulo Capital pela Universidade de São Paulo (2000). Fez Pós-Doutorado na Faculdade de Farmácia da UFMG (2001-2002), em Ciência dos Alimentos. Fez Pós-Doutorado na USP (20142015) em Nutrição em Saúde Pública. É Professora Titular da Universidade Federal do Piauí e Pesquisadora do CNPq. 


\section{RENATA LABRONICI BERTIN}

Nutricionista graduada pela Pontifícia Universidade Católica do Paraná (2004). Mestre em Nutrição pela Universidade Federal de Santa Catarina (2006). Doutora em Ciência dos Alimentos pela Universidade Federal de Santa Catarina (2014). Especialista em Nutrição Esportiva (2018). No mestrado, trabalhou com concepções e práticas do nutricionista na área hospitalar. Durante o doutorado estudou sobre compostos bioativos em alimentos. Atualmente é professora adjunta do Departamento de Nutrição da Universidade Federal do Paraná (UFPR), em que ministra disciplinas relacionadas à área de nutrição básica, bioquímica e análise de alimentos, nutrição e atividade física e prática ambulatorial para rendimento esportivo. Realiza pesquisas com enfoque na nutrição, fatores de risco e promoção a saúde em jovens universitários, consumo alimentar e nutrição na prática esportiva voltada para adolescentes. Membro do Núcleo Docente Estruturante (NDE) do Curso de Nutrição, do Comitê de Ética em Pesquisa com Seres Humanos do Setor de Ciências da Saúde e Vice-coordenadora da Especialização em Medicina do Exercício Físico na Promoção da Saúde (UFPR).

\section{RICARDO PEREIRA RIBEIRO}

Possui graduação em Zootecnia pela Universidade Estadual de Maringá (1987), mestrado em Genética e Melhoramento Animal pela Universidade Estadual Paulista Júlio de Mesquita Filho (1992) e doutorado em Ecologia de Ambientes Aquáticos Continentais pela Universidade Estadual de Maringá (1999). Atualmente é professor associado do Departamento de Zootecnia da Universidade Estadual de Maringá. Tem experiência na área de Manejo, Genética, Melhoramento Genético, Conservação Génética em peixes de água doce, atuando principalmente nos seguintes temas: Oreochromis niloticus, piscicultura, tilápia do nilo, reprodução de peixes e Piaractus mesopotamicus, Melhoramento Genético e Biologia Molecular.

\section{ROGÉRIO LOPES VIEITES}

Graduação em Agronomia (1984) pela Universidade Estadual Paulista Júlio de Mesquita Filho Faculdade de Ciências Agronômicas, Mestrado (1990) e Doutorado (1992) em Energia na Agricultura pela Faculdade de Ciências Agronômicas de Botucatu. Livre Docência (1998) na Área de Ciência e Tecnologia de Alimentos de Origem Vegetal. Professor Titular (2010) na Área de Ciência e Tecnologia de Alimentos de Origem Vegetal. Pós-Doutorado (2012) pela Universidad Politécnica de Cartagena - Espanha, Departamento de Ingeniería de Alimentos y Equipamentos Agricolas, no Grupo de Postrecolección y Refrigeración. Atualmente é (PROFESSOR TITULAR) da Universidade Estadual Paulista Júlio de Mesquita Filho, Faculdade de Ciências Agronômicas, ministra aulas para os cursos de graduação em Agronomia e Nutrição, na pós-graduação a nível de mestrado e doutorado nos programas Horticultura e Energia na Agricultura, e no curso de especialização em Ciência e Tecnologia de Alimentos. Tem experiência na Área de Ciência e Tecnologia de Alimentos, com ênfase em Tecnologia de Produtos de Origem Vegetal, atuando principalmente nos seguintes temas: pós-colheita, qualidade, irradiação, processamento mínimo e processamento de alimentos de origem vegetal. Bolsista Produtividade CNPq.

\section{ROSELI QUINTILIANO LIEIRA}

Possui graduação em Administração de Empresas pela Faculdade de Administração de Empresas de Catanduva(1995), graduação em Tecnologia em Alimentos pela Faculdade de Tecnologia de Marília - Estudante Rafael de Almeida Camarinha(2013) e mestrado em AGRONOMIA pela UNESP UNIVERSIDADE ESTADUAL PAULISTA "JÚLIO DE MESQUITA FILHO"(2017). Tem experiência na área de Ciência e Tecnologia de Alimentos, com ênfase em Tecnologia de Alimentos.

\section{RUI CARLOS ZAMBIAZI}

Possui graduação em Licenciatura Em Química pela Universidade Federal de Santa Maria (1982), graduação em Química Industrial pela Universidade Federal de Santa Maria (1982), mestrado em Ciência e Tecnologia de Alimentos pela Universidade Federal de Viçosa (1987) e doutorado em Food and Nutritional Science - University of Manitoba- Canadá (1997). Atualmente é professor 
Titular da Universidade Federal de Pelotas e Diretor do Centro de Ciências Químicas, Farmacêuticas e de Alimentos. Tem experiência na área de Ciência e Tecnologia de Alimentos, com ênfase em análises físico químicas e análises cromatográficas em alimentos. Atua nas linhas de pesquisas de identificação, quantificação e avaliação da estabilidade de fitoquímicos.

\section{SILVANA NEVES DE MELO}

Possui graduação em Agronomia pela Universidade Federal Rural da Amazônia e mestrado em Botânica pela Universidade Federal de Viçosa. Professora Assistente IV, lotada no Departamento de Tecnologia de Alimentos - DETA, do Centro de Ciências Naturais e Tecnologia - CCNT, da Universidade do Estado do Pará Tem atuação na área de Ciência e Tecnologia de produtos de origem vegetal, embalagem de alimentos e morfologia vegetal.

\section{SILVIA HELENA MARQUES DA SILVA}

Graduada, Bacharel em Biologia - Modalidade Biologia pela Universidade Federal do Pará (1997). Doutora em Ciências básicas com ênfase em Doenças Infecciosas e Parasitárias pela Universidade Federal de São Paulo - Escola Paulista de Medicina (UNIFESP-EPM) (2004). Pesquisadora em Saúde Pública, na Seção de Bacteriologia e Micologia do Instituto Evandro Chagas. Experiência na área de Microbiologia, com ênfase em Micologia Médica, atuando principalmente nos seguintes temas: diagnóstico das infecções fúngicas, produção e caracterização de antígenos fúngicos, diagnóstico sorológico das infecções fúngicas baseado na detecção de antígenos e anticorpos , Biologia molecular. Ensaios com Extratos botânicos como fonte de antimicrobianos.

\section{SILVIA MARIA GONÇALVES VIEIRA OTAVIO}

Graduada em Nutrição pela Faculdade Santo Agostinho de Teresina-FSA (2015), Especialização em nutrição clínica e funcional pela Faculdade Santo Agostinho de Teresina-FSA (2017). Formação em Modulação Intestinal (2018). Atualmente atua como nutricionista funcional e trabalho voluntário.

\section{SILVIA MENEZES DE FARIA PEREIRA}

Possui Bacharelado em Química pela Universidade Federal do Rio de Janeiro (1982), mestrado em Produção Vegetal pela Universidade Estadual do Norte Fluminense Darcy Ribeiro (1998) e doutorado em Engenharia e Ciência dos Materiais pela Universidade Estadual do Norte Fluminense Darcy Ribeiro (2002). Atua como Técnico Nível Superior no Laboratório de Tecnologia de Alimentos da Universidade Estadual do Norte Fluminense Darcy Ribeiro e Profa da Faculdade de Medicina de Campos-RJ.Tem experiência na área de Ciência e Tecnologia de Alimentos, com ênfase em constituintes químicos vegetais, antioxidantes e análise microbiológica e físico-química de alimentos.

\section{SIMONE VILELA TALMA}

Tecnóloga em Laticínios pelo IF Sudeste MG Campus Rio Pomba (2007-2009). Mestre e Doutora em Produção Vegetal/Tecnologia em Alimentos pela Universidade Estadual do Norte Fluminense Darcy Ribeiro - UENF (2010-2016). Atualmente é professor efetiva na área de Laticínios e Alimentos do Instituto Federal de Sergipe - IFS Campus Glória. Atua na área de Análise Sensorial, Aproveitamento de Resíduos, Desenvolvimento de Novos Produtos e Controle de Qualidade dos Alimentos.

\section{SOYANNE LIMA OLIVEIRA DE ALMEIDA}

Técnica em Agropecuária pelo Instituto Federal de Ciência e Tecnologia de Mato Grosso. Graduanda em Medicina Veterinária na Universidade Federal de Mato Grosso. Realizou estágio no Laboratório de Tecnologia de Pescado da Universidade Federal de Mato Grosso e integrou o Núcleo de Estudos em Pescado - NEPES, da Universidade Federal de Mato Grosso. 


\section{STELLA REGINA ARCANJO MEDEIROS}

Possui Pós-doutorado em Ciência e Tecnologia de Alimentos/CAPES/UFC, Doutorado em Biotecnologia - Rede Nordeste de Biotecnologia (RENORBIO) pela Universidade Estadual do Ceará (2011); Mestrado em Tecnologia de Alimentos pela Universidade Federal do Ceará (2005); Especialização em Vigilância Sanitária e Epidemiologia pela Universidade de Ribeirão Preto (1999); Graduação em Licenciatura Pleno no Programa Especial de Formação Pedagógica em Quimica pela Universidade Estadual do Ceará (2003) e Graduação em Engenharia de Alimentos pela Universidade Federal do Ceará (1998). Atualmente é professora Adjunto IV do Curso de Nutrição da Universidade Federal do Piauí, Campus Senador Helvídio Nunes de Barros.

\section{SUELEN PEREIRA RUIZ}

Graduada em Tecnologia em Alimentos pela Universidade Estadual de Maringá (2009). Mestrado em Ciência de Alimentos pela Universidade Estadual de Maringá (2012) e Doutorado em Ciência de Alimentos pela Universidade Estadual de Maringá (2016). Possui experiência na área de Ciência e Tecnologia de Alimentos, atuando principalmente sobre os seguintes temas: Microbiologia de Alimentos, Bioconservantes em alimentos, Bactérias ácidotermorreristentes, e Biotecnologia de alimentos.

\section{TAILISE B. ROLL ZIMMER}

Tecnóloga em Alimentos pela Universidade Federal de Pelotas (2016), Mestre em Ciência e Tecnologia de Alimentos (2019) pelo Programa de Pós - Graduação em Ciência e Tecnologia de Alimentos/ UFPEL. Atualmente é doutoranda em Ciência e Tecnologia de Alimentos pelo mesmo programa e instituição.

\section{THAYS SCOPEL}

Possui graduação em Tecnologia em Alimentos pela Universidade Tecnológica Federal do Paraná.

\section{TIAGO CARREGARI POLACHINI}

Doutorando em Engenharia e Ciência de Alimentos pela Universidade Estadual Paulista (UNESP/IBILCE) e em Ciencia, Tecnología y Gestión Alimentaria pela Universitat Politècnica de València (UPV) (Valencia/Espanha) no Grupo de Análisis y Simulación de Procesos Agroalimentarios (ASPA). Graduação e Mestrado em Engenharia de Alimentos pela Universidade Estadual Paulista (UNESP/IBIILCE). Experiência na determinação e modelagem de propriedades físicas, reologia, fluidodinâmica, isotermas de sorção, secagem de produtos da agroindústria, desenvolvimento e avaliação de processos agroalimentares assistidos por ultrassom de alta intensidade. 


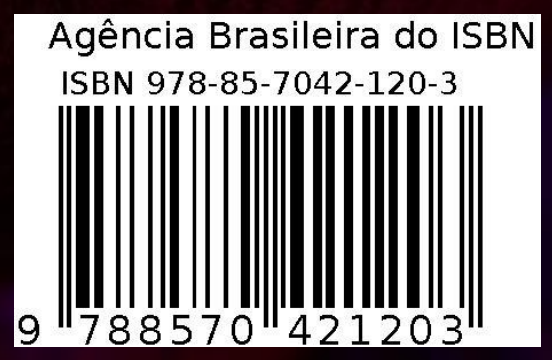

